NMAI CONTRIBUTIONS FROM THE Y, 4 nO. 3 MUSEUM OF THE AMERICAN INDIAN HEYE FOUNDATION

Volume IV, Number 3

THE NACOOCHEE MOUND IN GEORGIA

BY

GEORGE G. HEYE, F. W. HODGE, AND

GEORGE H. PEPPER

NEW YORK

MUSEUM OF THE AMERICAN INDIAN HEYE FOUNDATION

1918 


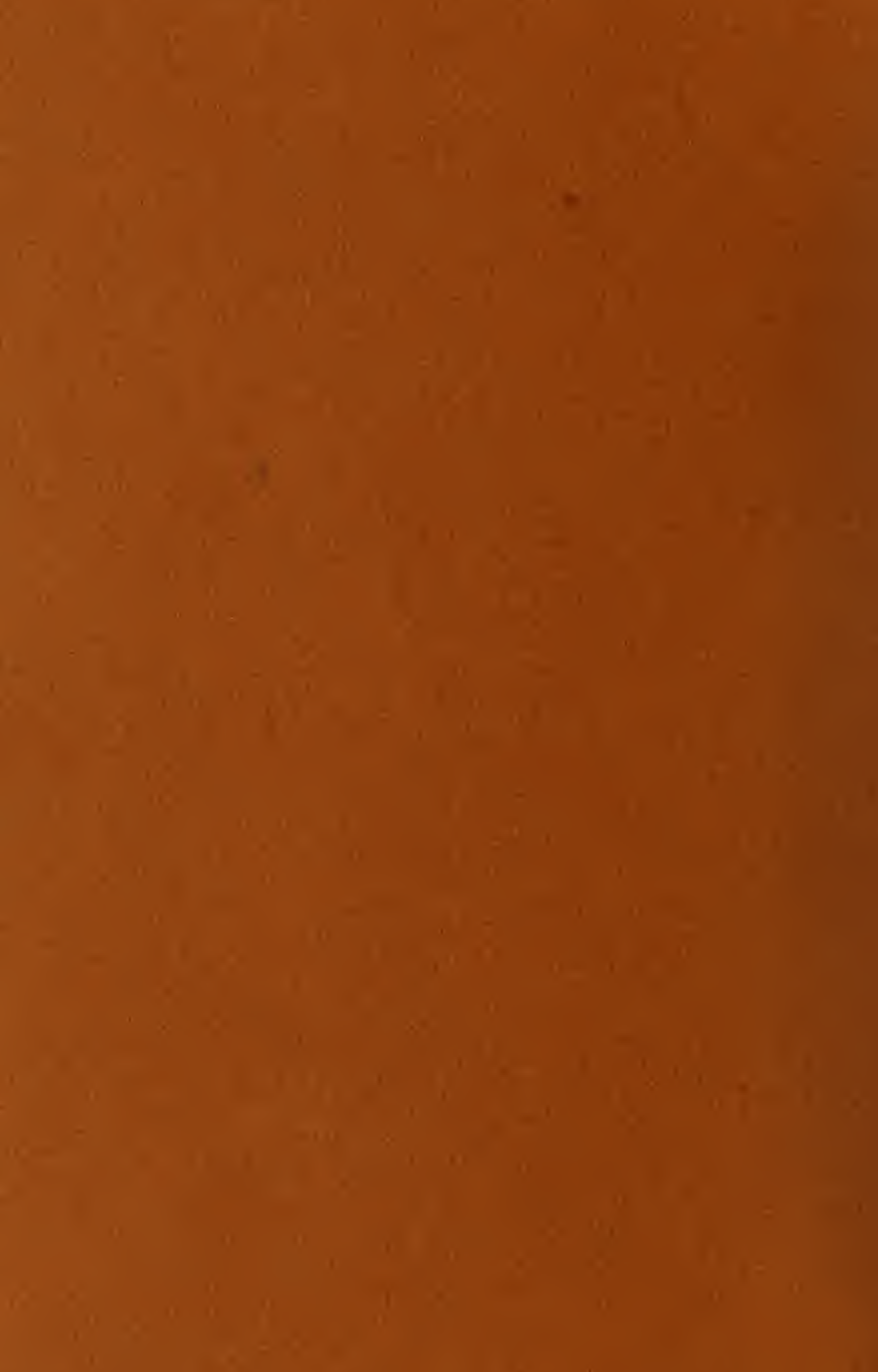





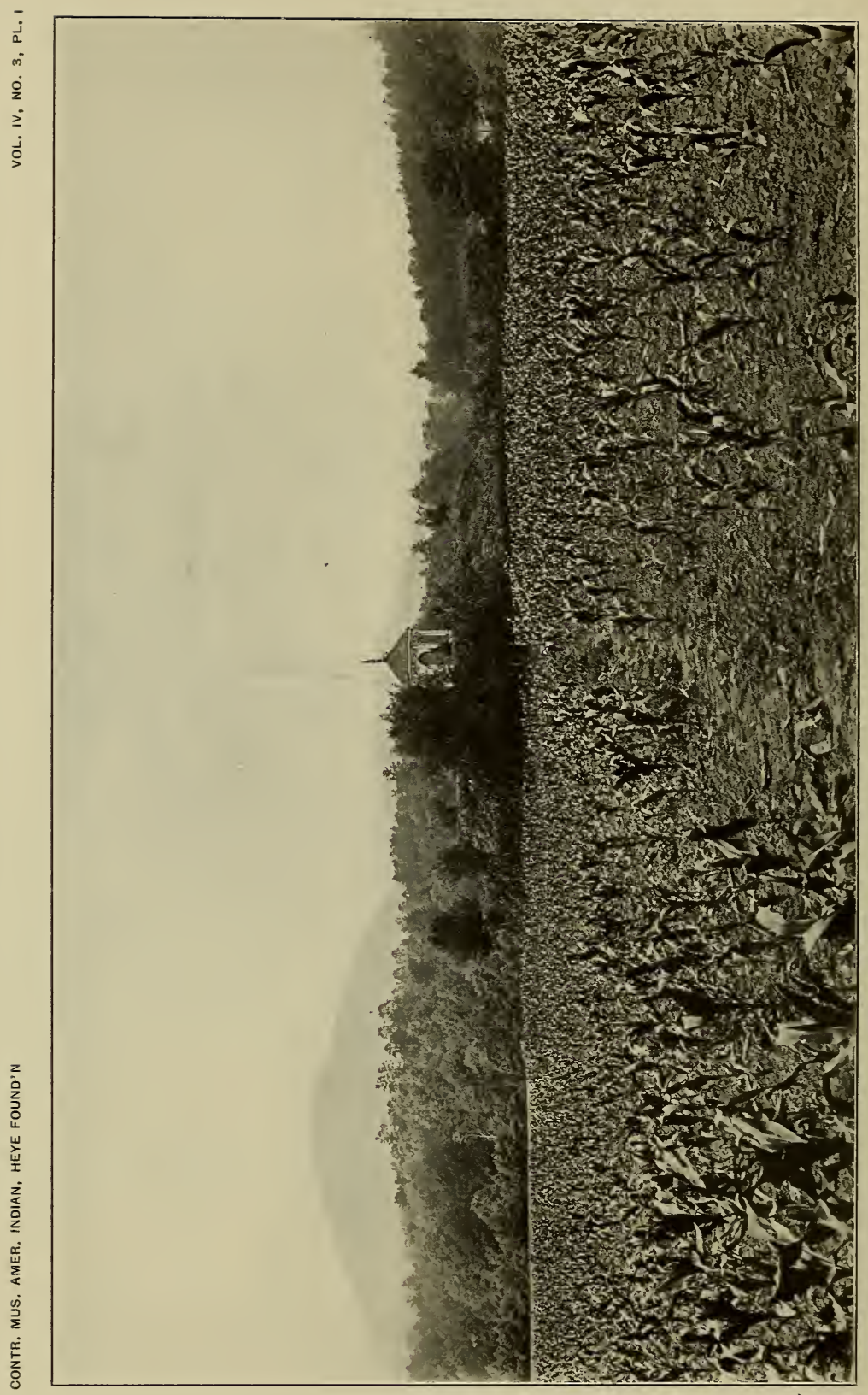


CONTRIBUTIONS FROM THE

MUSEUM OF THE AMERICAN INDIAN

HEYE FOUNDATION

Volume IV, Number 3

\title{
THE NACOOCHEE MOUND IN GEORGIA
}

\author{
BY \\ GEORGE G. HEYE, F. W. HODGE, \\ AND \\ GEORGE H. PEPPER
}

\begin{abstract}
NEW YORK
MUSEUM OF THE AMERICAN INDIAN HEYE FOUNDATION
\end{abstract}

I9I 8 



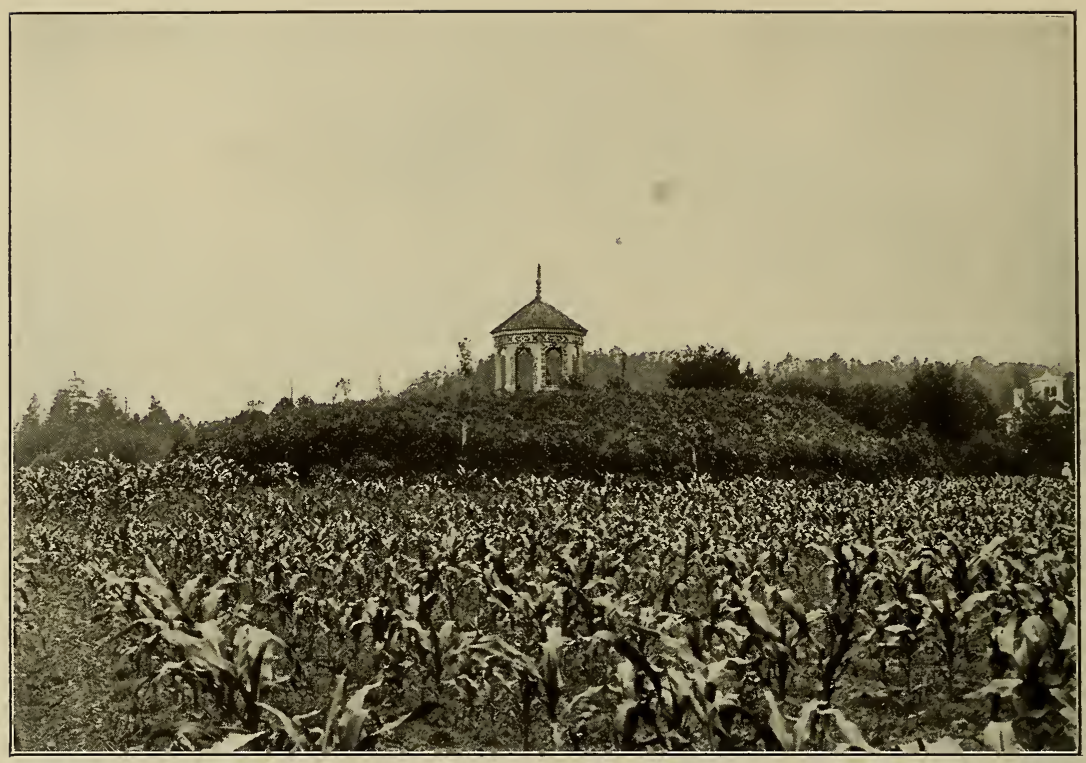

A. NACOOCHEE MOUND FROM THE SOUTHEAST, BEFORE EXCAVATION

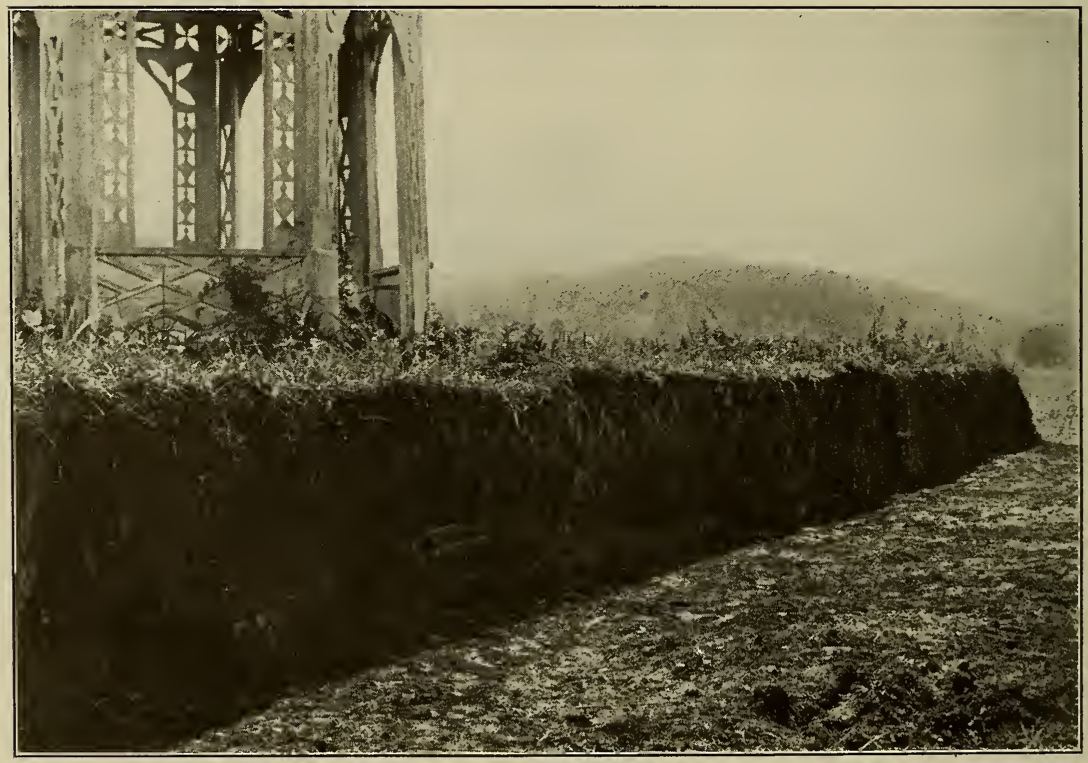

B. EXCAVATION OF A FOUR-FOOT SECTION FROM THE SUMMIT 


\title{
THE NACOOCHEE MOUND IN GEORGIA
}

\author{
BY \\ GEORGE G. HEYE, F. W. HODGE, AND \\ GEORGE H. PEPPER
}

\section{INTRODUCTION}

T $\mathrm{N}$ the attractive little Nacoochee valley, drained by the extreme headwaters of the Chattahoochee between Sautee and Soquee creeks in White county, northeastern Georgia, and within the shadow of Mount Yonah which looms toward the southeast (pl. I), rises an artificial mound, slightly more than seventeen feet in maximum height, which forms a conspicuous landmark in the region. This earthwork, which stands about 300 yards north of the river, was excavated to a considerable extent in the summer of $19 \mathrm{I} 5$ by a joint expedition of the Museum of the American Indian, Heye Foundation, and the Bureau of American Ethnology of the Smithsonian Institution. . The slope of the mound was steep, and its base clearly marked from the surrounding field owing to extended cultivation during many years and the plowing away of the lower part of the sides (pl. II, $a$ ). Moreover, the top of the mound had also been plowed away years before to afford a level space for the erection of a summer-house and the planting of a garden, water for which had been piped from the adjacent residence, now the home of Dr L. G. Hardman, the owner of the land on which the earthwork is situated. In view of this change in the configuration of the mound and the fact that wear by the elements in this unusually wet region during a considerable period between its abandonment by the Indians and the settlement of Nacoochee valley by whites, the measurements made in I9I5 do not indicate, perhaps within many feet, the original height and circumference.

Permission to excavate the Nacoochee mound was granted by Dr Hardman for a consideration mutually satisfactory and on 
condition that its form be restored and any precious metals found during the progress of the work should be placed in the owner's hands. As in other parts of the country, the belief is prevalent in Georgia, even among educated people, that hoards of gold are hidden beneath earthworks reared by Indians in ancient times, and this belief is especially current in northern Georgia where gold was found in the early part of the last century, a mint being established at Dahlonega in I838 and maintained for some years. A preliminary examination of the Nacoochee site was made in May, I9I5; active operations were commenced on June I9 by Mr Heye and continued until July 2 , when, during his absence of a few days, the excavation was in charge of Mr E. F. Coffin, of the Museum staff, who presented daily reports. Mr Hodge joined in the work early in July, from which time the excavations proceeded under the coöperation of himself and Mr Heye. Conditions necessitating the return of Mr Heye to New York and of Mr Hodge to Washington late in August, the work was continued from the 28 th of the latter month until October 29 under the immediate charge of Mr Pepper, assisted by Mr Coffin. Thus the Nacoochee excavations were conducted uninterruptedly for a period of more than four months. While it has been found convenient for Mr Hodge to prepare this report, it must be understood as embodying not only the results of his own observations on the features of the site and of the artifacts found, but those of Messrs Heye and Pepper as well.

Although it was the intention to excavate the mound completely, conditions were such, especially those occasioned by excessive rainfall, that it was not possible to remove the entire earthwork during a single field season, and a satisfactory concession for the resumption of the work in the following summer could not be obtained from the owner. The present report, therefore, embodies the results of the excavation by the joint expedition, together with some information published by C. C. Jones in 1873 , and such knowledge respecting the earlier history of Nacoochee as has come down to us.

\section{HISTORY}

Of the history of the Nacoochee site very little is known, and although the name itself is a corruption of the Cherokee form 

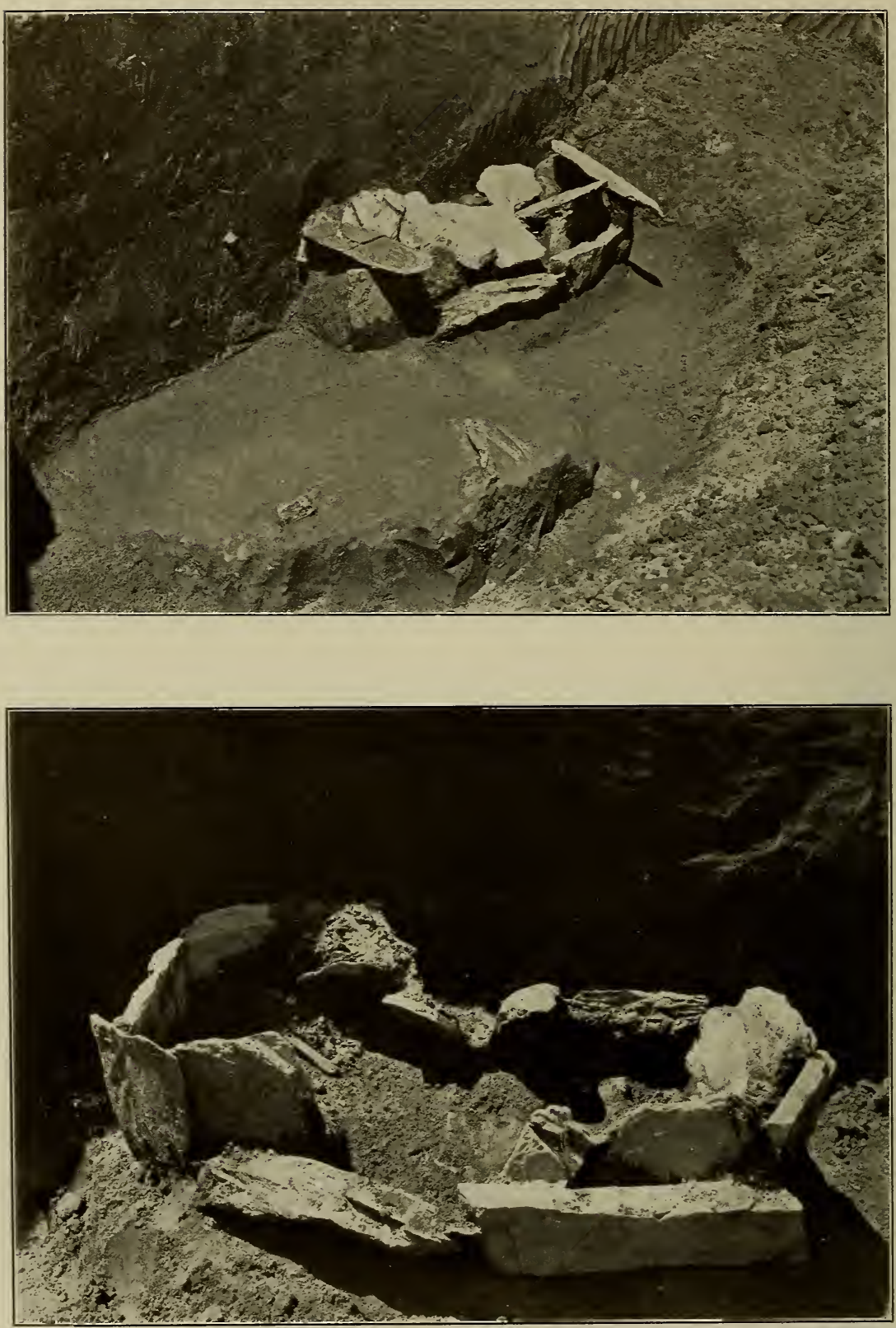

STONE GRAVE（BURIAL 34） 
Nagu'ts'", "the meaning of the word is lost and it is doubtful if it be of Cherokee origin." ${ }^{1} \mathrm{Mr}$ Mooney suggests that the name may have some connection with that of the Yuchi Indians; and according to information communicated to the writer by the late H. S. Halbert, who possessed a wide knowledge of the Choctaw language, the term so closely resembles the Choctaw nakushi, which signifies "little arrow," as to suggest Muskhogean derivation.

That Nacoochee was a village of the Cherokee Indians during historic times, there is no question. The settlement first became known to the Spaniards of the De Soto expedition, who visited it in the latter part of May, I540. The narrations of this expedition have been summarized by Mr Mooney, so that it is not necessary for the purpose of this paper to present anew the accounts given by the chief chroniclers of that remarkable journey of the Spanish forces. Mr Mooney says:

"After several days of such travel they arrived, about the end of the month, at the town of Guasili, or Guaxule. The chief and principal men came out some distance to welcome them, dressed in fine robes of skins, with feather head-dresses, after the fashion of the country. Before reaching this point the queen [the chieftainess of Cofitachiqui, probably a Yuchi province and town, who had been made a prisoner] had managed to make her escape, together with three slaves of the Spaniards, and the last that was heard of her was that she was on her way back to her own country with one of the runaways as her husband. What grieved De Soto most was that she took with her a small box of pearls, which he had intended to take from her before releasing her, but had left with her for the present in order 'not to discontent her altogether.'

"Guaxule is described as a very large town surrounded by a number of small mountain streams which united to form the large river down which the Spaniards proceeded after leaving the place. ${ }^{2}$ Here, as else-

${ }^{1}$ James Mooney, Myths of the Cherokee, Nineteenth Annual Report of the Bureau of American Ethnology, Vol. I, pp. 526-527, Washington, I902. Mr Mooney states that the name Itsâ'tî likewise was applied to the Nacoochee mound, although primarily it was the proper form of Little Echota, on Little Tennessee river, and of Echota, on Sautee creek.

${ }^{2}$ The streams referred to, no doubt, are Soquee and Sautee creeks which unite to form the Chattahoochee. The principal mountains in the vicinity, peaks of the Blue Ridge, are Mount. Yonah, Sall's Mountain, and Lynch's Mountain. 
where, the Indians received the white men with kindness and hospitality - so much so that the name of Guaxule became to the army a synonym for good fortune. Among other things, they gave the Spaniards three hundred dogs for food, although, according to the Elvas narrative, the Indians themselves did not eat them. The principal officers of the expedition were lodged in the 'chief's house,' by which we are to understand the townhouse, which was upon a high hill with a roadway to the top. From a close study of the narrative it appears that this 'hill' was no other than the great Nacoochee mound, in White county, Georgia, a few miles northwest of the present Clarkesville. It was within the Cherokee territory, and the town was probably a settlement of that tribe. From here De Soto sent runners ahead to notify the chief of Chiaha of his approach, in o der that sufficient corn might be ready on his arrival." 1

"In five days of such travel-for here, for a wonder, all the narratives agree-they came to Guaxule. This is the form given by Garcilaso and the Gentleman of Elvas; Biedma has Guasula, and Ranjel Guasili or Guasuli. The translators and commentators have given us such forms as Guachoule, Quaxule, Quaxulla, and Quexale. According to the Spanish method of writing Indian words, the name was pronounced Washulé or Wasuli, which has a Cherokee sound, although it can not be translated. Buckingham Smith (Narratives, p. 222) hints that the Spaniards may have changed Guasili to Guasule, because of the similarity of the latter form to a town name in southern Spain. Such corruptions of Indian names are of frequent occurrence. Garcilaso speaks of it as a 'province and town,' while Biedma and Ranjel call it simply a town ('pueblo'). Before reaching this place the Indian queen had managed to make her escape. All the chroniclers tell of the kind reception which the Spaniards met here, but the only description of the town itself is from Garcilaso, who says it was situated in the midst of many small streams which came down from the mountains round about, that it consisted of three hundred houses, which is probably an exaggeration, though it goes to show that the village was of considerable size, and that the chief's house, in which the principal officers were lodged, was upon a high hill ('un cerro alto'), around which was a roadway ('paseadero') wide enough for six men to walk abreast. By the 'chief's house' we are to understand the townhouse, while from various similar references in other parts of the narrative there can be no doubt that the 'hill' upon which it stood was an artificial mound. In modern Spanish writing such artificial

${ }^{1}$ Mooney, op. cit., pp. 25-26. 
. 

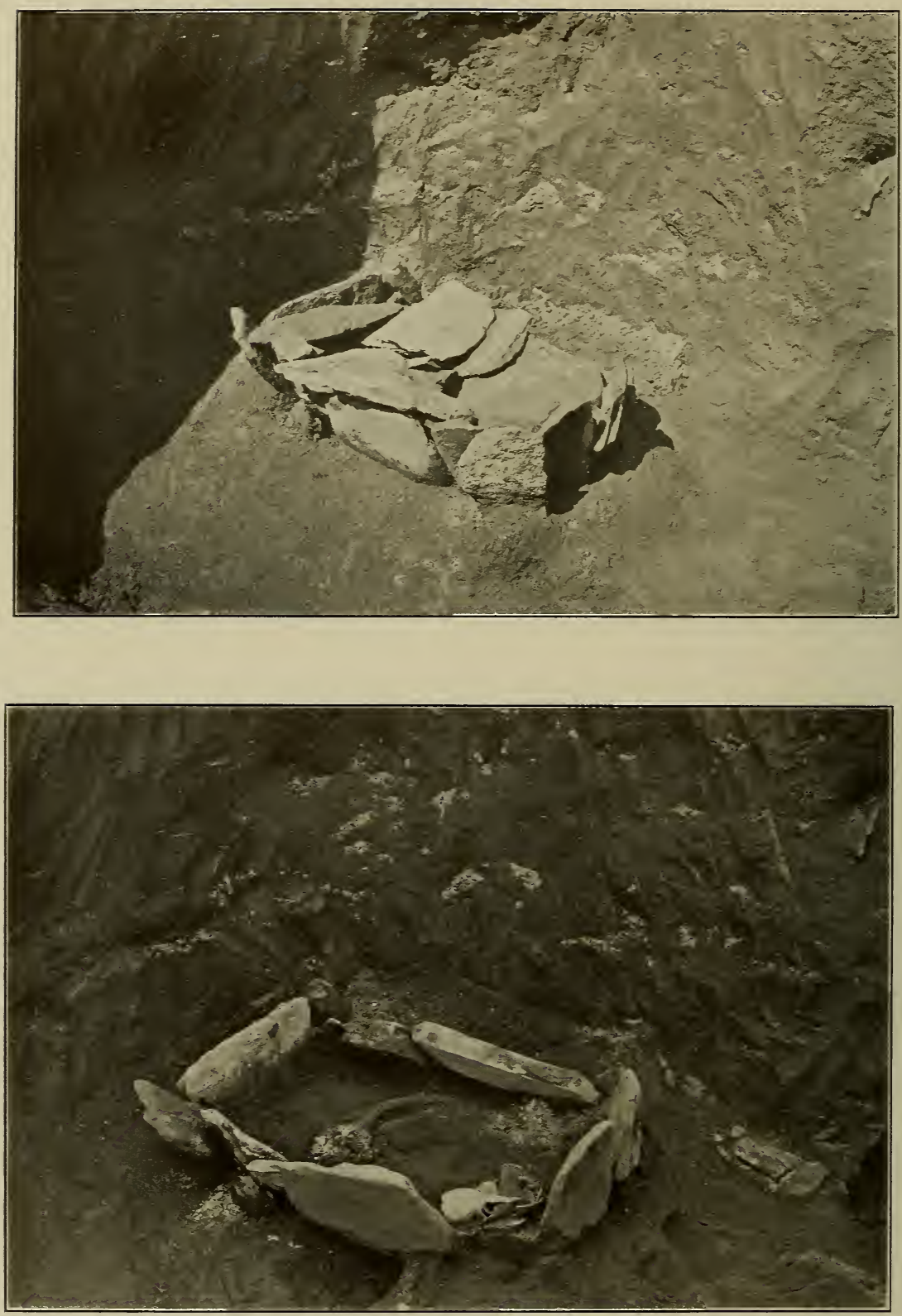

STONE GRAVE (BURIAL 39) BEFORE AND AFTER REMOVAL OF THE COVERING SLABS 
elevations are more often called lomas, but these early adventurers may be excused for not noting the distinction. Issuing from the mountains round about the town were numerous small streams, which united to form the river which the Spaniards henceforth followed from here to Chiaha, where it was as large as the Guadalquivir at Sevilla." 1

Nacoochee seems also to have been visited by Juan Pardo in I567, if we may identify his "Cauchi" with the name of that settlement, which is possible but not certain. ${ }^{2}$

The settlement is mentioned by Bartram, ${ }^{3}$ under the name Nae oche, an evident misprint of Nacoche, as among the fortythree towns of the Cherokee in 1776; and it appears as Naguchee, between Echotee and Cussatee, on "An Accurate Map of North and South Carolina," etc., by Henry Mouzon and others, I775, in Thomas Jefferys' American Atlas, map 23, London, I776. It does not appear, however, in a list of fifty-one settlements in a distribution roll of Cherokee annuities of $1799,{ }^{4}$ although this omission is not to be regarded as conclusive evidence that Nacoochee did not exist at that time. The Nacoochee valley was on the free public road laid out between I8I3 and I8I5 which extended from Tennessee river to the head of navigation on the Tugaloo branch of Savannah river, which became the great highway from the coast to the Tennessee settlements. ${ }^{5}$ The valley was included in the great area of land ceded by the tribe to the United States by the treaty of Washington, February 27 , I8I $9,^{6}$ following the treaty of July 8 , I8I 7 , by which the Cherokee ceded their lands lying east of the Chattahoochee in Georgia, hence it probably was not very long after that time that the Cherokee abandoned this and various other villages, when their removal first to Arkansas, thence to the present Oklahoma, was commenced. By the treaty of December 29, I835, all the remaining lands of the Cherokee east of the Mississippi were relinquished to the Government.

${ }^{1}$ Mooney, ibid., pp. 195-196.

${ }^{2}$ Mooney, ibid., p. 29.

${ }^{3}$ William Bartram, Travels through North and South Carolina, and Georgia, etc., p. 372 , London, I792; also Dublin, I793.

${ }^{4}$ C. C. Royce, The Cherokee Nation of Indians, Fifth Annual Report of the Bureau of Ethnology, p. I44, Washington, 1887 .

${ }^{5}$ Mooney, op. cit., p. 87 .

${ }^{6}$ Royce, op. cit., pp. 2 I9 ff. 
The time when the Cherokee still occupied the Nacoochee valley was within the memory of old inhabitants who have passed away within the last few years, while it is written of George W. Williams, of Charleston, S. C., that in 1823 his father removed from North Carolina to the Nacoochee valley, then "on the very border of civilization, inhabited principally by Cherokee Indians"; and, again, that his father, "who was one of the original settlers here about the time the Indians were driven away, owned a large portion of Nacoochee valley, taught his sons the science of farming; they ploughed up gunlocks, swords, broken shells, bullets, tomahawks, arrows, human bones and the like." 1 The two statements may not be entirely consistent, but they suggest the occupancy of the valley by the Cherokee for a short time after the treaty of I8I9. Further evidence that the settlement was not abandoned until well within the nineteenth century is afforded by the finding by us of a Spanish coin of Carlos IV, dated I808, in the refuse under the northeastern base of the mound.

Although not the earliest account of the so-called "Indian legend" of Nacoochee, ${ }^{2}$ that of Williams is probably most responsible for the exploitation of the ridiculous yarn, set forth as of Indian origin, respecting the beautiful Nacoochee and her Choctaw lover Sautee, after whom the two streams bearing those designations are alleged to have been named. The Spaniards of De Soto's army are forced into the romance, and although there is not a grain of truth in the assertion that any Indians ever related such an un-Indian legend, and the entire fabric of the story is imaginary, it has received such currency that no argument can dismiss it from the minds even of those otherwise intelligent. It is not improbable that the myth of the Indian "princess" may have had its origin in the "queen" of Cofitachiqui who ran off with one of the negro slaves of the Spaniards as her husband.

${ }^{1}$ George W. Williams, Relics of a Forgotten Race in Nacoochee, Ga., and Its Surroundings, pp. 70,95 , Charleston, I903.

2 See the romance of the "Indian Princess Nacoochee, "The Evening Star,", in Rev. George White's Historical Collections of Georgia, pp. 486-487, New York, I854 


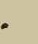



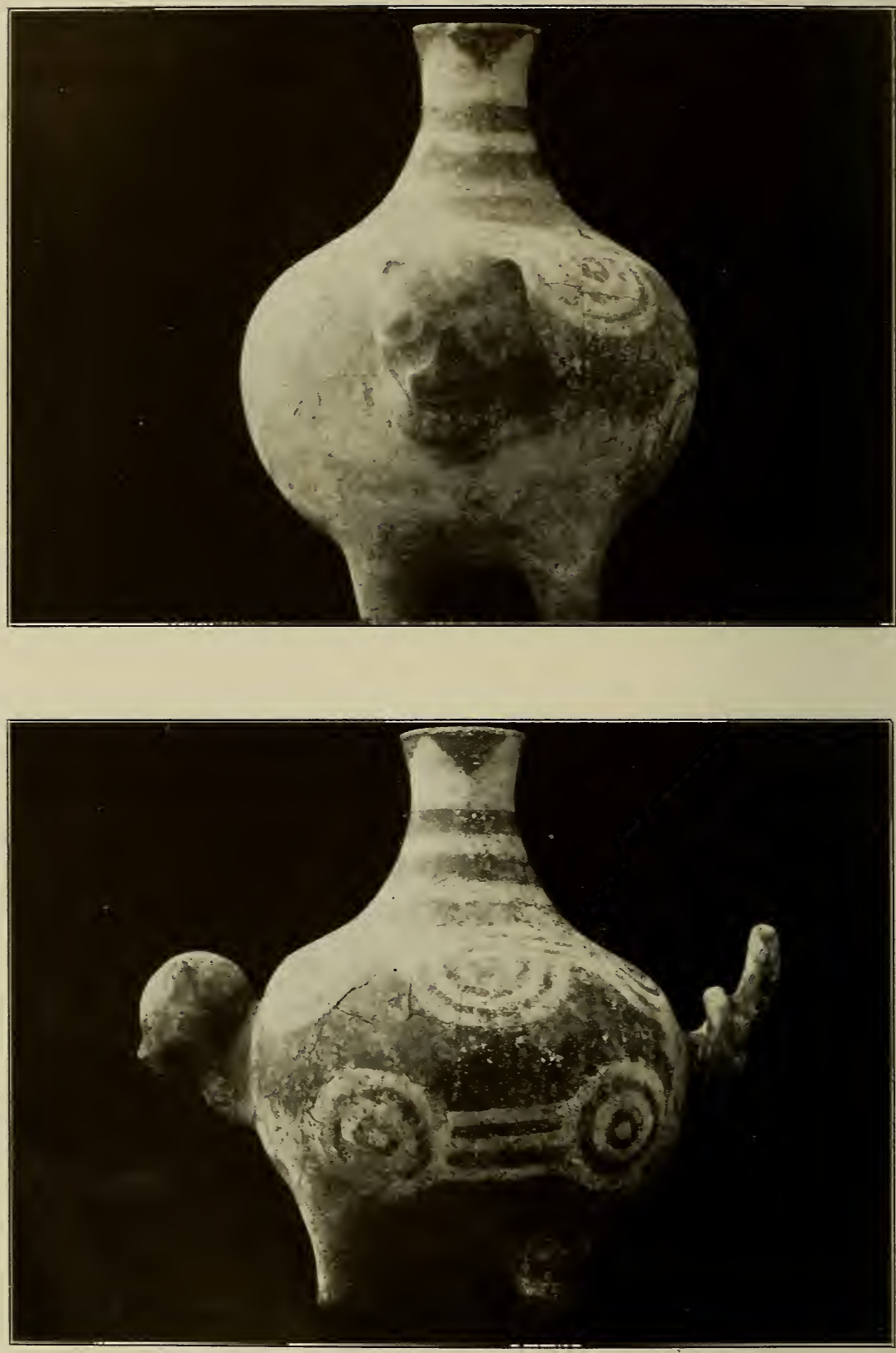

EFFIGY VASE FROM THE NACOOCHEE MOUND 


\section{CHARACTER OF THE MOUND}

Fortunately a description of the condition of the Nacoochee mound forty-five years ago was recorded by Charles C. Jones, ${ }^{1}$ whose observations are worthy of repetition here for the sake of comparison.

"In the upper part of Nacooche valley, and near its western extremity, is a prominent earth-mound. Located not far from the Chattahooche river, and rising some 20 feet or more above the surface of the surrounding valley, it has long constituted a marked feature in this beautiful region. For many years its slopes and summit have been cultivated, and, within the recollection of the older inhabitants, this tumulus has lost much of its original dimensions. [More or less] elliptical in shape, it has a flat top, declining somewhat toward the southwest. Measured in a northeasterly and southwesterly direction, at right angles, its base-diameters are, respectively, 190, and 150 feet; while its apexdiameters, ascertained in the same directions, do not fall short of 90 and 60 feet. It is entirely artificial, and appears to be wholly composed of the earth gathered from the neighborhood of its base. There are no terraces, the sides sloping gradually from the summit. Tradition has preserved no memories of the people by whom it was erected, and its treasures, if any, are still concealed within its own bosom." .

A survey of the mound by $\mathrm{Mr}$ Heye and $\mathrm{Mr}$ Coffin before excavation was commenced, showed its N.E.-S.W. diameter on the summit to have been $78 \mathrm{ft}$. and its N.W.-S.E. diameter $67 \mathrm{ft} .4$ in., which latter was the minimum diameter of the apex. The maximum diameter of the top, however, was $82 \mathrm{ft} .9$ in. from north to south. The shape of the summit is shown in fig. $I$, which represents a circumference of about 23I feet. The circumference as measured at the base was $4 \mathrm{IO} \mathrm{ft}$., while the maximum height of the mound was $\mathrm{I} 7 \mathrm{ft} .3$ in. As before indicated, these measurements are of interest only as showing the condition before excavation, and by no means represent the dimensions of the mound at the time of its abandonment. As Jones remarks, there was no sign of a terrace or roadway, such as that which characterized the ancient Guaxule. Little was to have been expected in the way of remains at the surface of the summit, as it was learned from a mechanic who had

${ }^{1}$ Antiquities of the Southern Indians, pp. 213-2I4, New York, 1873. 
been employed in building the pagoda, still preserved, twenty-seven years before, that about two feet of the top had been removed at that time. Subsequently the sides had been dug away more or

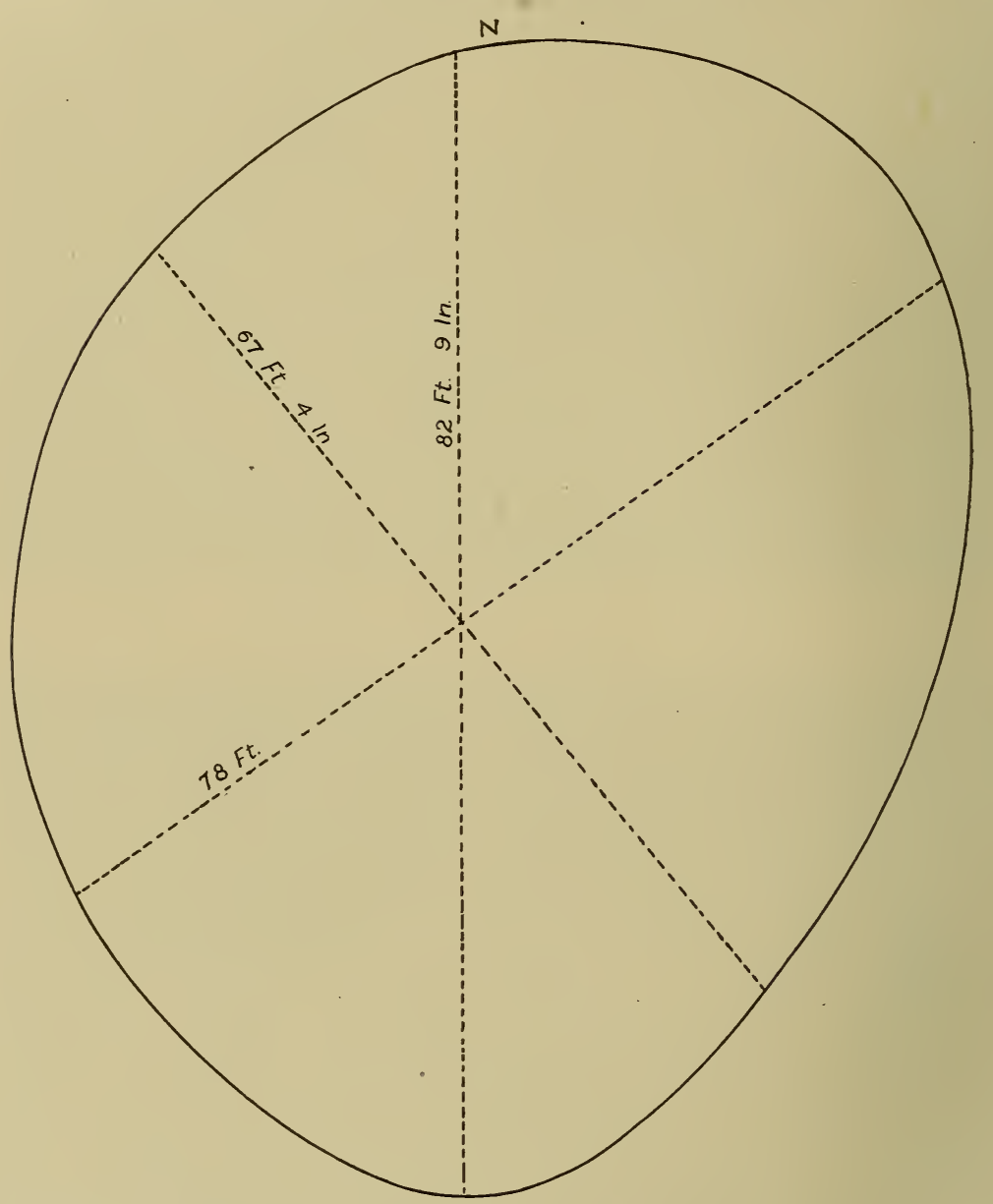

FIG. I.-Outline of the summit of the Nacoochee mound at the time of excavation.

less, forming a steep conventional terrace which was planted in vines and shrubbery, and the mound fenced.

As mentioned by Jones, the mound is composed mainly of earth 


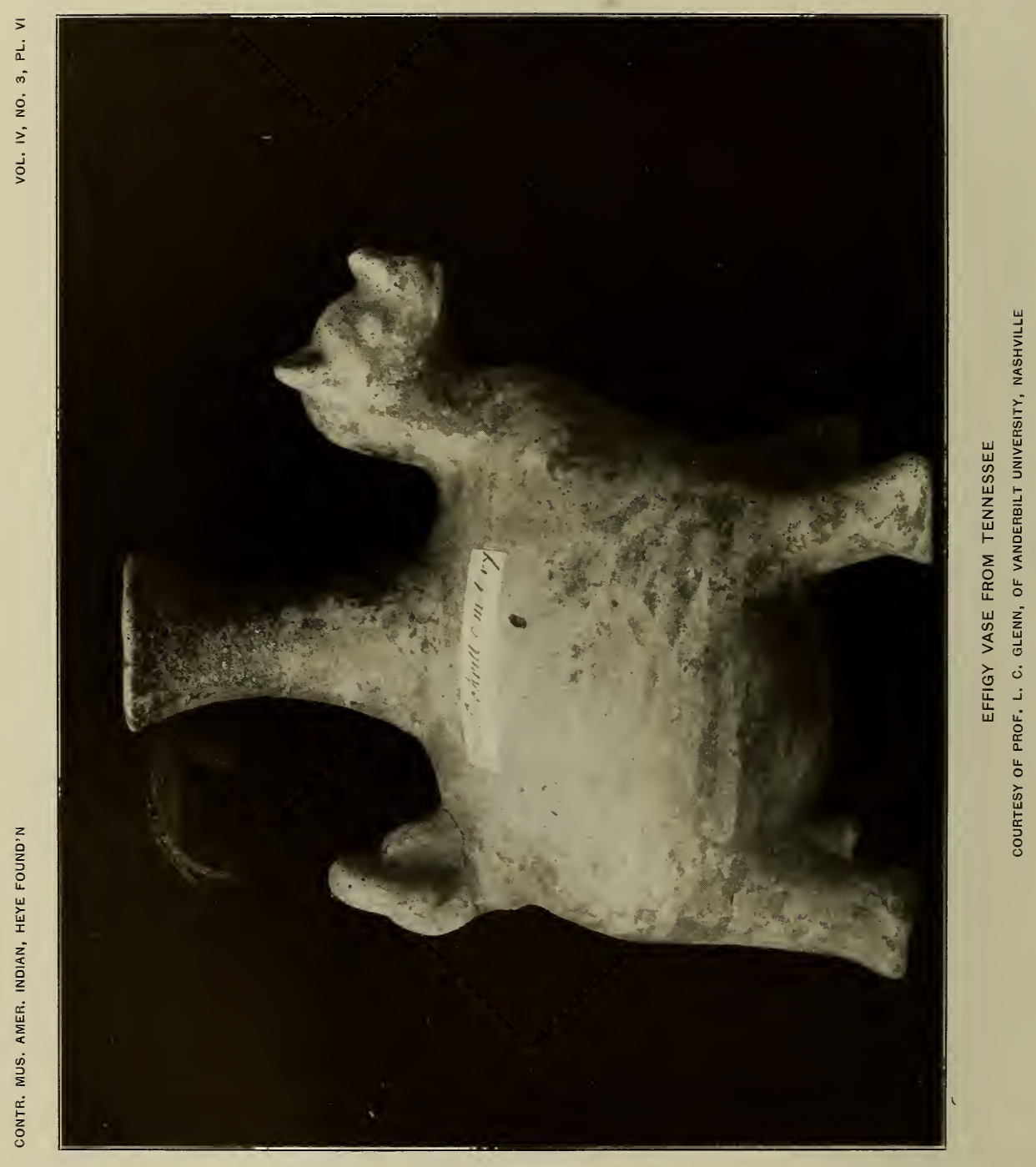


taken from the surrounding field, which consists of a rich dark clayey soil containing a considerable proportion of silica and alumina. It was early observed in the course of the excavation that this soil became bright red on contact with fire, the change in color being especially apparent in the numerous evidences of firepits.throughout the mound. An analysis by Dr Edgar Everhart, chemist of the Geological Survey of Georgia, made by the courtesy of Prof. S. W. McCallie, State Geologist, gave the following result:

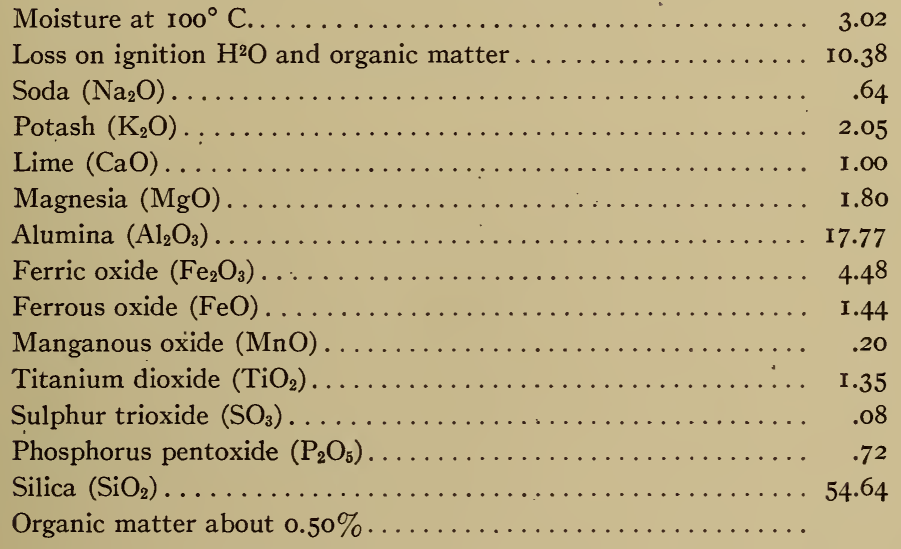

Total

99.57

The purpose of the Nacoochee mound was primarily domiciliary, that is, as in the case of so many earthworks in the South, it was the site of the town-house, the dwellings of the village proper being erected in the surrounding flat land. A glimpse of a typical settlement of the Cherokee in the eighteenth century, before these tribesmen had become greatly modified by contact with encroaching civilization, may aid us in visualizing the conditions existing at Nacoochee at the time of its occupancy. William Bartram, a man of scientific attainments, who visited a number of Cherokee settlements during a journey through the South in $1773-78$, wrote as follows on the subject of Cherokee houses, his description, although evidently applying especially to the village of Cowee, situated at the mouth of Cowee creek of Little Tennessee river, in Macon 
county, N. C., being characteristic of Cherokee towns in general. ${ }^{1}$

"The Cherokees construct their habitations on a different plan from the Creeks; that is, but one oblong four square building, of one story high; the materials consisting of logs or trunks of trees, stripped of their bark, notched at their ends, fixed one upon another, and afterwards plaistered well, both inside and out, with clay well tempered with dry grass, and the whole covered or roofed with the bark of the chesnut tree or long broad shingles. This building is however partitioned transversely, forming three apartments, which communicate with each other by inside doors; each house or habitation has besides a little conical house covered with dirt, which is called the winter or hot-house; this stands a few yards distance from the mansion-house, opposite the front door.

"The council or town-house is a large rotunda, capable of accommodating several hundred people: it stands on the top of an ancient artificial mount of earth, of about twenty feet perpendicular, and the rotunda on the top of it being above thirty feet more, gives the whole fabric an elevation of about sixty feet from the common surface of the ground. But it may be proper to observe, that this mount on which the rotunda stands, is of a much ancienter date than the building, and perhaps was raised for another purpose. The Cherokees themselves are as ignorant as we are, by what people or for what purpose these artificial hills were raised; they have various stories concerning them, the best of which amount to no more than mere conjecture, and leave us entirely in the dark; but they have a tradition common with the other nations of Indians, that they found them in much the same condition as they now appear, when their forefathers arrived from the West and possessed themselves of the country, after vanquishing the nations of red men who then inhabited it, who themselves found these mounts when they took possession of the country, the former possessors delivering the same story concerning them: perhaps they were designed and appropriated by the people who constructed them, to some religious purpose, as great altars and temples similar to the high places and sacred groves anciently amongst the Canaanites and other nations of Palestine and Judea.

"The rotunda is constructed after the following manner: they first fix in the ground a circular range of posts or trunks of trees, about six feet high, at equal distances, which are notched at top, to receive into them from one to another, a range of beams or wall plates; within this is another circular order of very large and strong pillars, above twelve feet

\footnotetext{
${ }^{1}$ Op. cit., pp. 365-366.
} 


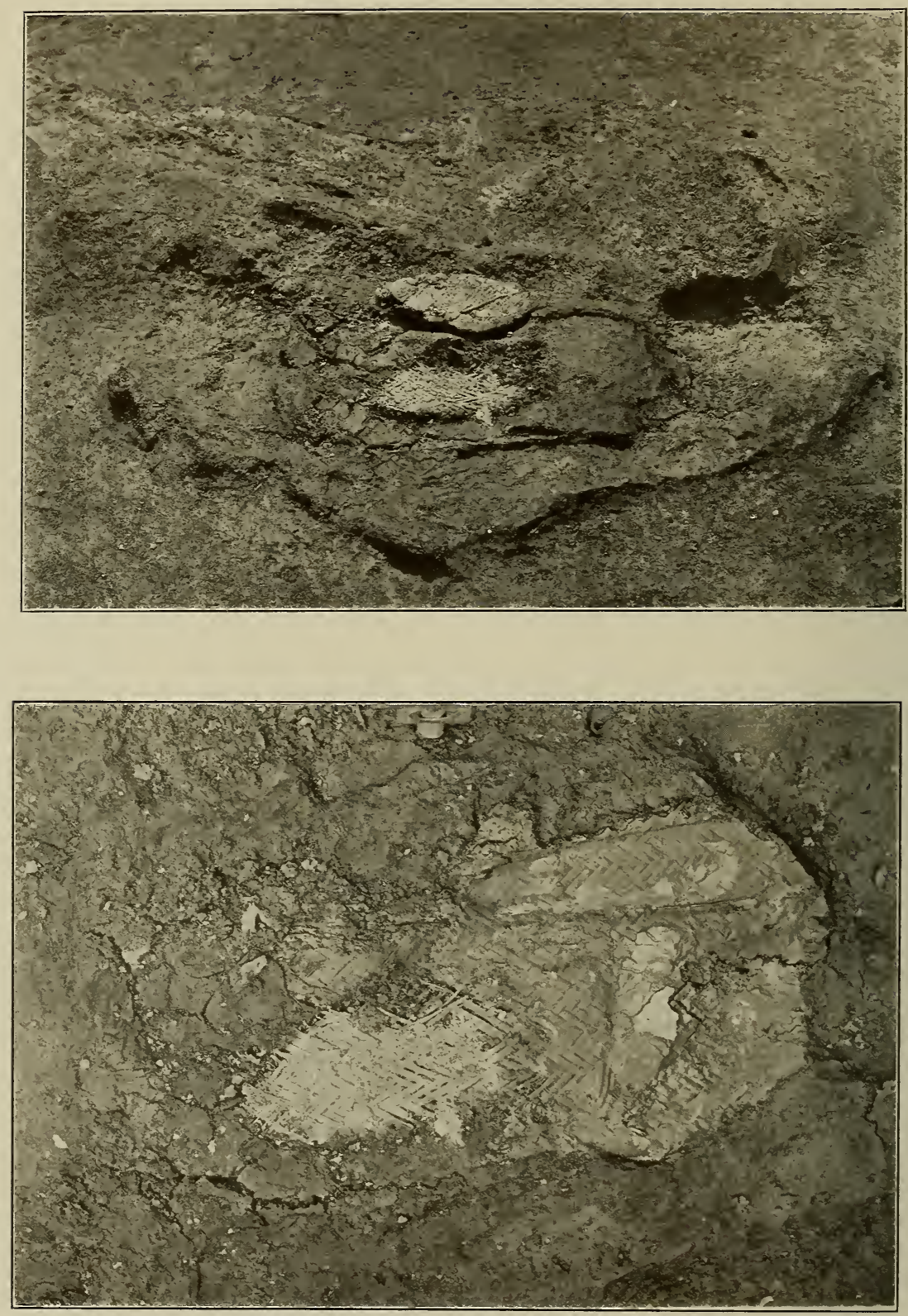

MATTING FOUND WITH BURIAL 46

THE LOWER FIGURE SHOWS THE IMPRESSION OF THE COPPER AXE AND ITS HANDLE BENEATH THE MATTING 



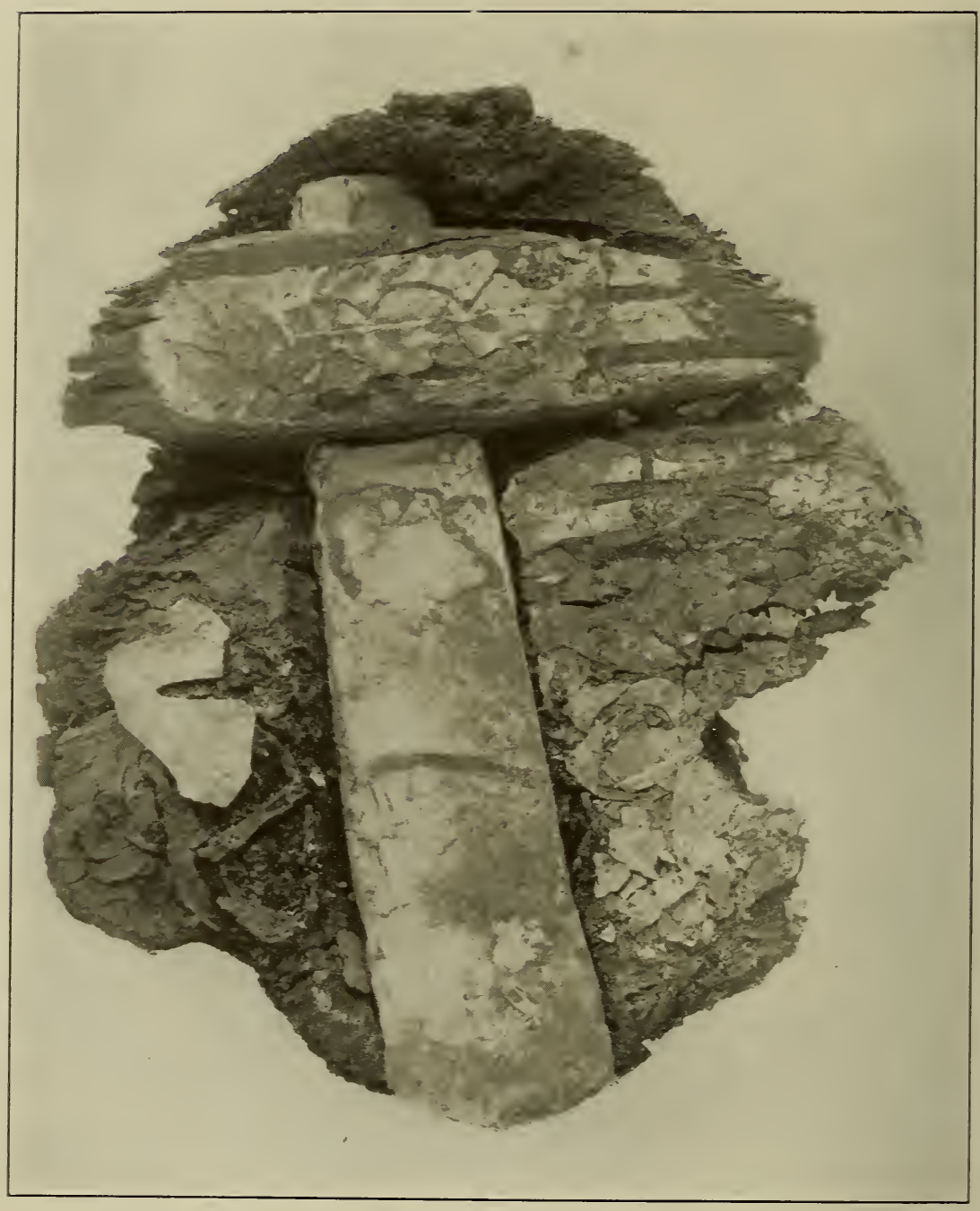


high, notched in like manner at top, to receive another range of wall plates; and within this is yet another or third range of stronger and higher pillars, but fewer in number, and standing at a greater distance from each other; and lastly, in the center stands a very strong pillar, which forms the pinnacle of the building, and to which the rafters centre at top; these rafters are strengthened and bound together by cross beams and laths, which sustain the roof or covering, which is a layer of bark neatly placed, and tight enough to exclude the rain, and sometimes they cast a thin superficies of earth over all. There is but one large door, which serves at the same time to admit light from without and the smoak to escape when a fire is kindled; but as there is but a small fire kept, sufficient to give light at night, and that fed with dry small sound wood divested of its bark, there is but little smoak. All around the inside of the building, betwixt the second range of pillars and the wall, is a range of cabins or sophas, consisting of two or three steps, one above or behind the other, in theatrical order, where the assembly sit or lean down; these sophas are covered with mats or carpets, very curiously made of thin splints of Ash or Oak, woven or platted together; near the great pillar in the centre the fire is kindled for light, near which the musicians seat themselves, and round about this the performers exhibit their dances and other shows at public festivals, which happen almost every night throughout the year."

We have already noted the statement by Jones that tradition has preserved no memories of the people by whom the Nacoochee mound was erected, and while Bartram lends support to the mysterious origin of mounds occupied by the Cherokee, there is no doubt that the tribe built and occupied various mounds and that Nacoochee was one of them. On this subject, as well as on the reason for the selection of village sites near streams, Mooney ${ }^{1}$ comments as follows:

"The Cherokee town-houses were necessarily located in the immediate vicinity of a stream, and where there was about it a level area. The reasons for this were ( $\mathrm{I}$ ) that the dances were held around and about these public houses, frequently beginning inside, and (2) ceremonial bathing formed an important part of the proceedings connected with their sacred dances, such as the green-corn dance and the medicine dance, where the whole body of the performers came out of the town-house to

${ }^{1}$ Cited by Cyrus Thomas, The Cherokees in Pre-Columbian Times, pp. 63-64, New York, r89o. 
the water, and, after certain ablutions, returned thereto. It was necessary, therefore, that the building be near a stream. As the level areas in their narrow mountain valleys are often overflowed, it is quite probable that in order to place these sacred houses above the floods, they were, as stated in tradition, located on artificial mounds: Moreover, the townhouse was the depository of numerous ceremonial objects which could not readily be removed in a sudden emergency. And, as it is said traditionally that a sacred fire was kept burning on a peculiar excavation in the center of the earthen floor, this could not be removed from the hearth-place, and hence some provision for its protection was necessary."

\section{STONE CISTS AND RELATED GRAVES IN THE LOWER LEVELS}

The first record of excavation of the Nacoochee mound is found in Jones's work, ${ }^{1}$ from which we quote as follows:

"In June, I870, Capt. J. H. Nichols, while ploughing in the vicinity of this tumulus, discorered, several inches below the surface of the field, a number of large stone slabs. They were lying at a remove of about thirty feet from the western slope of the mound.... During the progress of the investigation, he unearthed three stone graves, quite near each other, but not disposed in a uniform direction. These graves were parallelogrammic in shape, being seven feet long, three feet wide, and a little more than two feet and a half deep. They were all filled with earth, and the surface of the field above them was somewhat elevated beyond the level of the surrounding valley. The sides consisted of rough slabs of slate, between two and three feet long, and about two feet wide, set up on end. The bottom of the central grave was paved with oval boulders which had evidently been obtained from the bed of the Chattahoochee. But one of the three-and that the central grave-was covered. For the covering, or lid, flat slabs of stone rather more than three feet in length had been employed; so that when they rested upon the upright sides and ends of the grave, the enclosure of this vault or rude sarcophagus was complete.

"In this central grave a male skeleton, measuring more than six feet, lay extended at full length. Each of the other two graves contained the bones of more than one skeleton lying in disorder, and carelessly piled in without any regard to regularity. It was obvious that these bones were in a detached condition when they were placed in these

${ }^{1}$ Op. cit., pp. 2I 4-2I 5, 223-224. 

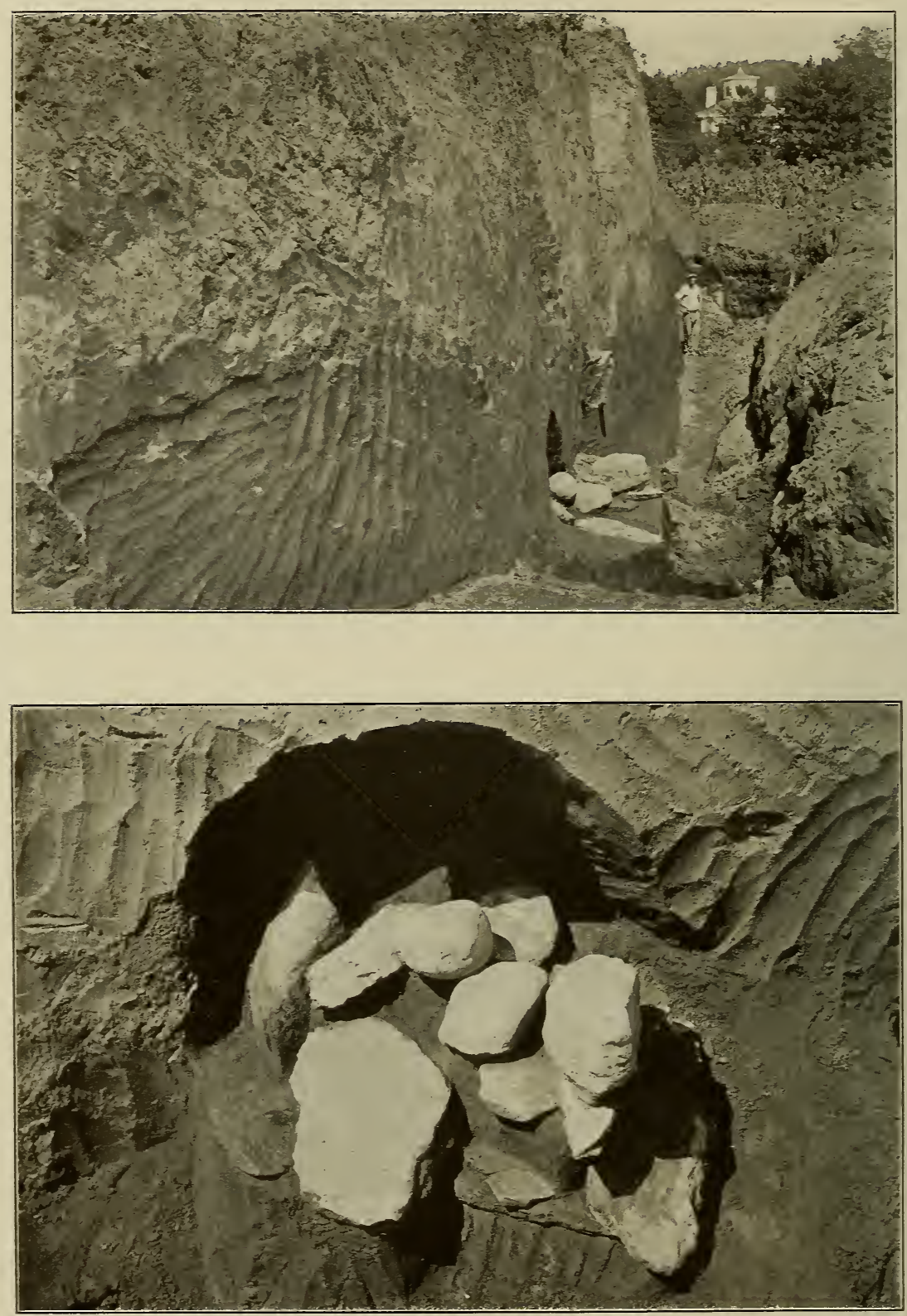

STONE GRAVE (BURIAL 53) 
enclosures. It seemed impossible from them to construct distinct and complete skeletons. When removed from the graves and exposed to the air, most of them crumbled. Further investigation will probably develop the existence of other stone graves of similar construction in this vicinity."

Jones then refers to the occurrence of stone graves in Tennessee, Missouri, and Illinois, adding: "It is perhaps not unlikely that the Chaouanons [Shawnee] constructed many of these Tennessee graves, and, crossing the mountains which intervened, peopled Nacoochee valley and other portions of Georgia." $1 \mathrm{He}$ continues:

"An examination of the stone graves of Nacoochee valley inclines us to the belief that to the prevalence of some such custom as this [reserving corpses for a general inhumation and then stripping them of the flesh for ultimate reburial] are the two graves indebted for the remains of several dead enclosed within them. The lack of order in the disposition of the bones, and the careless commingling of various portions of several skeletons, are evident, while in the central grave the corpse was carefully laid at full length upon the stone flooring. As we proceed, we will perceive additional reasons for conjecturing that this grave formed the receptacle of some chief or warrior of note. He was a man of great stature. The few teeth remaining in the lower jaw were much worn, and the alveolar processes had been greatly absorbed. Unfortunately, the skull was in such a decayed condition that it could not be preserved. . . .

"As we have remarked, each of these graves contained human remains. In the central grave was the skeleton of an old man more than six feet high. This corpse had been carefully deposited upon the floor of the vault, at full length, the arms lying parallel with the body. In the other two graves the bones had been disposed without any regard to regularity. Portions of several skeletons were found in each, and it was evident that they had been inhumed in utter disregard of every thing savoring of order. None of these graves had been disturbed previous to this examination. Although located in a cleared field, which had been cultivated for a number of years, the ploughshare had never before touched the stone covering which sheltered them."

1 For the distribution of stone graves in the Southern states and for numerous descriptions and illustrations of such remains in Tennessee, see Moore, Aboriginal Sites on Tennessee River, Jour. Acad. Nat. Sci. Phila., vol. xvi, I9I 5. 
Jones then describes in detail the objects found with the skeleton in the central grave, ${ }^{1}$ namely,

I. An implement of pure copper (nearly Io in. long, $23 / 4$ in. wide at the cutting edge and 2 in. wide at the helve, with an almost uniform thickness of a little less than a tenth of an inch, and a weight of $93 / 4$ oz.) which lay near the shoulder, and beneath it a piece of matting, consisting of thin layers of split cane about a quarter of an inch wide, interwoven at right angles, "probably the remnant of the sheath or basket which enclosed it." Doubtless this cane was Arundinaria macrosperma Mx., which grows abundantly along the banks of the Chattahoochee near by. The fragment found showed traces of dyeing, some of the splints being black, others yellow. An inch and a quarter from the upper end of the copper blade, and extending diagonally across it, was a smooth worn space on each side, about $\mathrm{I} 1 / 4 \mathrm{in}$. wide, "showing where and how this axe was inserted in its handle. . . . That it had been used is evident both by the abrasion caused by the handle, and also by the fact that the cutting edge is somewhat split and broken." But Jones says the axe is so thin that "it seems scarcely probable that it could have been applied to any general practical uses," although he dwells especially on the abrasion of the copper at the point of contact with the former handle and the splitting and breakage of the cutting edge, which could hardly have been possible if the implement were used only "as a badge of distinction and treasured as a valuable ornament or possession, and not employed as a weapon of war or used for incisive purposes." The surface of the axe "is considerably oxidated, except where it was surrounded by the handle, which would indicate not only that it was attached to the handle at the time of its inhumation, but also that the handle must have consisted of some hard substance. . . . The handle had worn that portion of the axe which it enclosed quite smooth; and this fact, while evincing no inconsiderable use, tended to render such part least liable to decomposition or oxidation. No trace of the handle remained in the grave." It may be said, however, that although there may have been some abrasion at the

1 Jones, op. cit., pp. $225^{-238}$. 



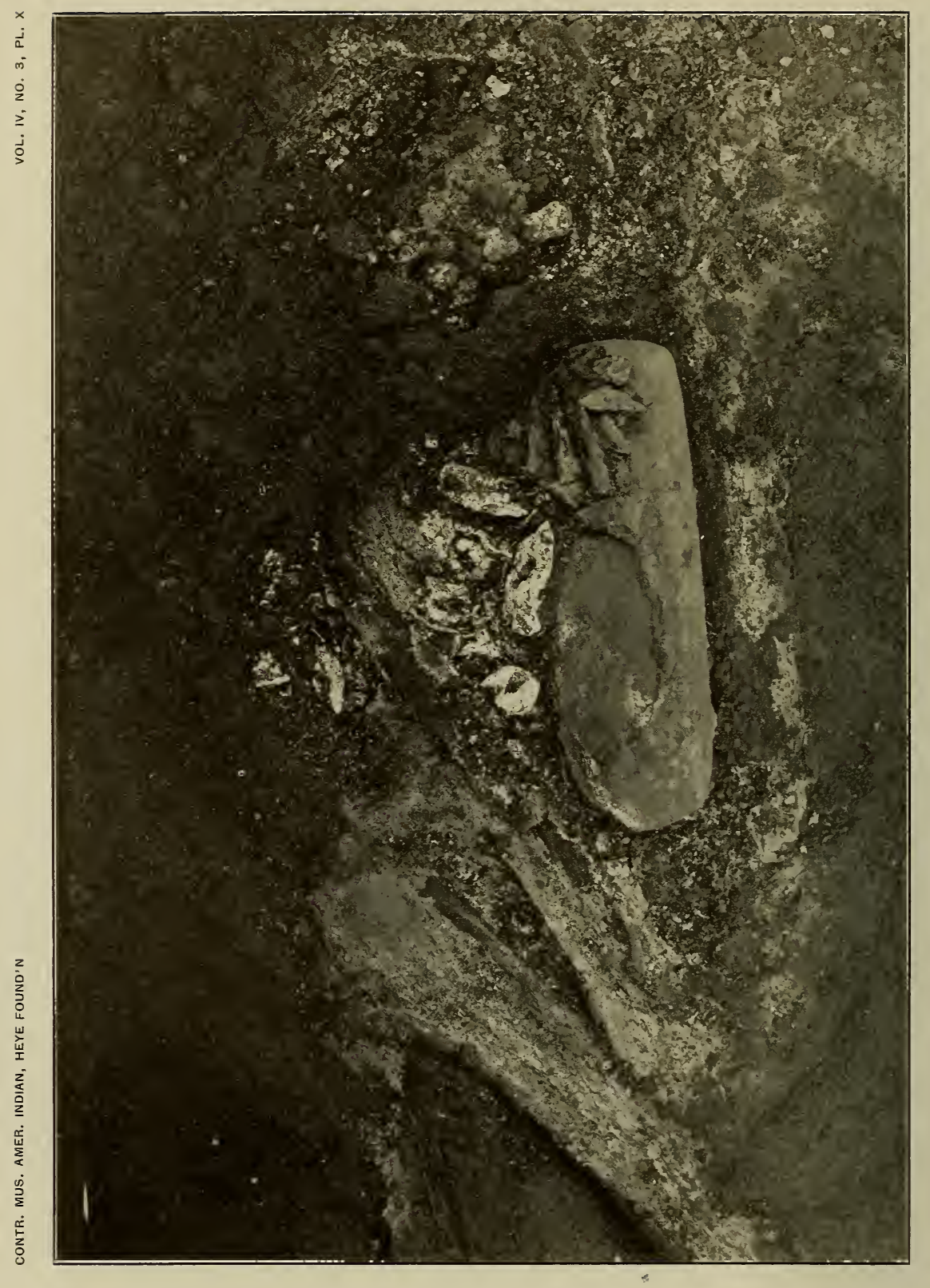

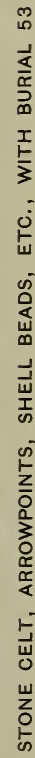


point referred to, the entire celt may have been equally smooth at the time of its burial. In the opinion of Jones (p. 23I), "the metal of which the Nacoochee axe is formed was obtained from the shores of Lake Superior, and that probably the implement itself was there made." In this connection we may mention the fact that the Spaniards of De Soto's expedition saw copper axes in use among the Georgia Indians in the sixteenth century.

2. Two specimens of Cassis flammea, one of them from the central grave, measuring nearly 10 in. in length and about 7 in. in diameter, from each of which the interior whorls and columellæ had been removed to adapt them for use as drinking-cups or some other form of receptacle. "These conchs," says Jones, "were brought from the Southern Atlantic coast, or from the shores of the Gulf of Mexico."

3. Four small copper rods, which Jones conjectured "may be the spindles alluded to by the historians of De Soto's expedition, with which, when heated, the natives were wont to perforate pearls so that they could be strung and worn as beads."

4. A pin-shaped soapstone ornament, carefully polished, a little less than 2 in. long, with the head rather more than half an inch in diameter. (See pp. 7I, 85.)

5. Several shell pins, one of which, about $13 / 4$ in. long, is like a large-headed wrought nail, somewhat similar in form, although shorter and more pointed, to the soapstone ornament mentioned. The other shell pin is rather irregular in shape, with both ends pointed. The pins with heads, Jones says, were made from the columellæ of some big univalve, such as Strombus gigas. (See p. 93.)

6. A flat perforated stone, with a beveled aperture, size not given, but perhaps not exceeding an inch in diameter, which Jones believed was suspended as an ornament.

7. An imperforate discoidal stone.

8. A grooved axe badly worn. (See p. 84.)

9. A beautifully polished wedge-shaped axe or celt of stone.

I0. A chisel of greenstone.

II. A fragment of a soapstone pipe.

I2. A large stone bead. 
These complete the list of specimens taken from the graves beyond the western base of the mound, but in the vicinity were plowed up fifty-five Venetian beads, varying in shape and color, and in addition Captain Nichols found a plain, thin-walled, black slate pipe with the bowl and the stem at a slightly obtuse angle (pl. $\mathrm{L}, b$ ), an earthenware pipe of bird effigy form, and a paint mortar of brown jasper. "No trace of iron, bronze, or steel existed in these graves," says Jones (p. 23i). "The presence of the copper axe and stone implements furnishes good ground for believing that their owner had enjoyed no opportunity for exchanging his rude weapons and ornaments for the more serviceable tools which, at an early period, were freely offered by the colonists. This fact, and the total absence of the old Venetian beads found in the neighborhood, and undoubtedly once the property of the Indians, enable us, with considerable confidence, to assign to these graves an antiquity of not less than three hundred and thirty years. ${ }^{1}$ Probably they are much older."

So much for the objects found at the Nacoochee site fortyfive years before the excavations conducted in 1915. We have dwelt at length on Jones's observations for the reason that they relate to artifacts associated with the earliest period of the occupancy of the site, as well as to graves and their accompanying objects similar to those uncovered during the progress of our own work and at the same level, although at the opposite side of the mound.

We may preface the description of the circumstances attending the finding of the stone graves and their contents at the eastern base of the earthwork by explaining that the excavation of the Nacoochee mound was commenced at the summit by the removal of a stratum of the soil four feet deep, excepting the middle part occupied by the summer-house (pl. II, $b$ ). This finished, a second stratum of four feet was removed, and so on until, at the eastern side, it was possible to reach the very base of the tumulus without danger to the workmen by caving of the bank. At the same side,

1 The author here evidently had in mind the occupancy of Nacoochee at the time of De Soto in 1540 . 


$$
\text { - }
$$




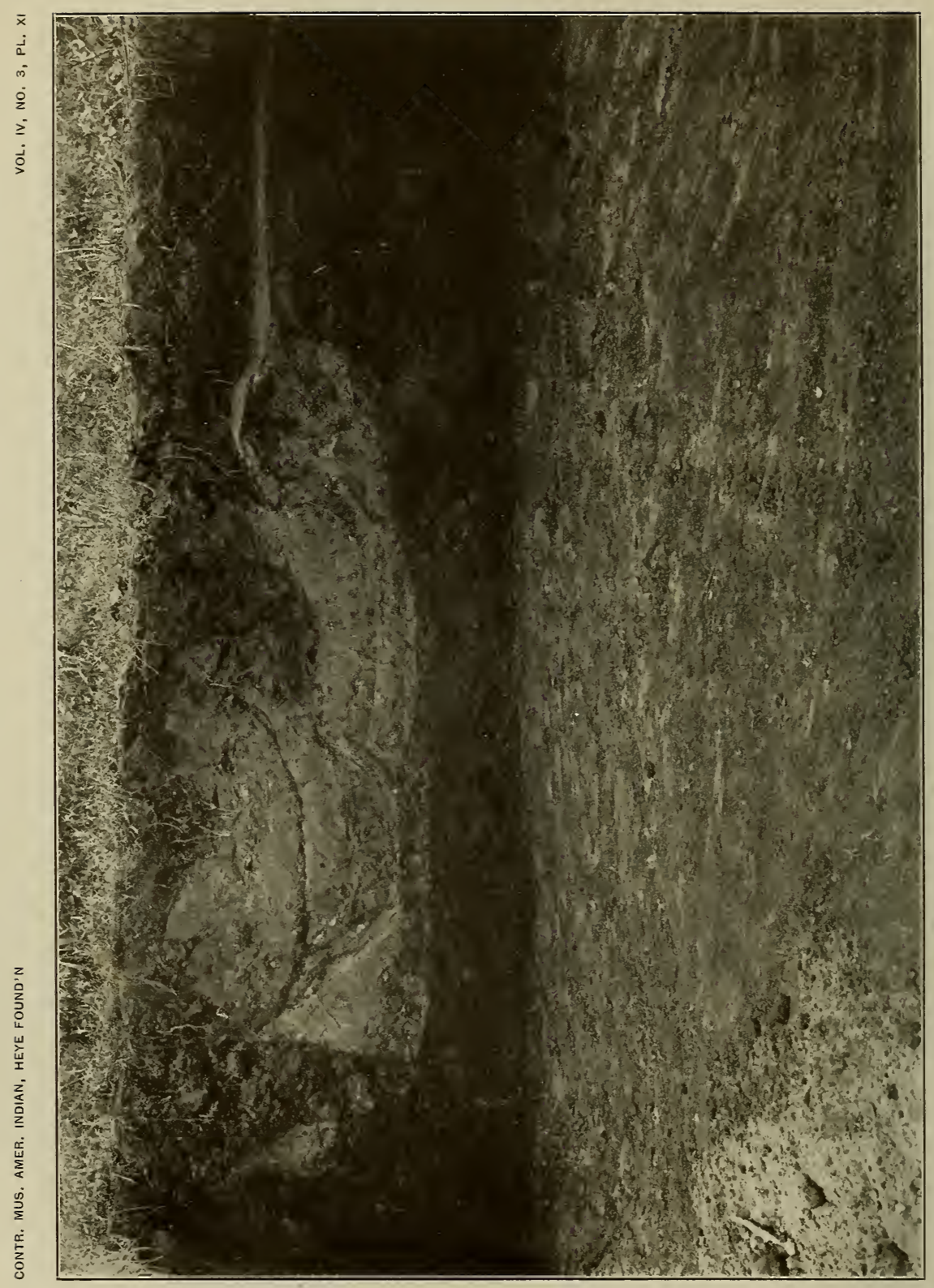

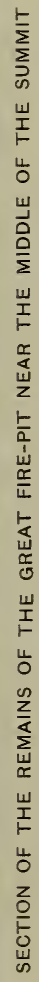


Io $\mathrm{ft} .6$ in. below the summit level, was exposed the top of the first stone-box grave, $5 \mathrm{ft}$. Io in. in maximum length, $3 \mathrm{ft}$. in maximum width, 22 in. in height, and bearing N.E.-S.w. (pl. III). This sepulcher (Burial 34) contained the greatly decomposed remains of the skeleton of an adult, headed N.E., extended on the left side. The grave was partly filled with earth which had sifted in owing to pressure that had forced the grave stones forming the western side inward and those of the eastern side outward, causing the covering slabs to fall partly into the enclosure. That this grave had been constructed long before the mound acquired its maximum height is certain, as the strata immediately above the western side of the grave was undisturbed, showing that the cist had been placed only slightly beneath the surface at the time it was built. The bottom of the grave was floored with slabs of stone. Under and projecting rearward from the neck of the skeleton was a completely flattened shell, apparently part of a conch, of the consistency of lime, within which was a piece of micaceous schist; and in the same condition were two small univalve shell beads found about the position of the right ear. No other artifacts were found in this grave.

About four feet east of this grave, but at a depth of $\mathrm{I} 7 \mathrm{ft} .5$ in. from the summit of the mound to the bottom of the grave, and I4 ft. 9 in. beneath the slope (i. e., about $5 \mathrm{ft}$. deeper than Burial 34), was another stone-box grave (Burial 39), measuring only $4 \mathrm{ft} .7$ in. by $3 \mathrm{ft}$. 10 in., by $2 \mathrm{ft} .6$ in. in maximum height (pl. Iv). The inside measurement of this grave was $3 \mathrm{ft}$. Io in. long by $2 \mathrm{ft}$. 5 in. wide. In some respects this interment was the most interesting of the many uncovered at Nacoochee, by reason of the finding, among other objects, of an earthenware effigy vessel of painted ware, the only specimen of painted pottery, with the exception of a small sherd recovered from the same section of the mound and at approximately the same depth, found during the entire exploration. The body had been laid on its right side, with the head directed eastwardly, on a layer of bark placed on the earthen floor. The bones of the trunk had almost disappeared through decay, but were sufficiently traceable to indicate that the body had been bowed 
greatly outward, while the upper leg-bones, which were in somewhat better condition, were flexed strongly upward and the lower legbones lay against the pelvis. This distortion was evidently necessary because of the small size of the grave. The skull, which was of the consistency of cornmeal owing to decay and the ravages of insects, lay in the upper left-hand or northwest corner of the cist.

When the top of this grave was encountered, it was found necessary to remove a large mass of superposed soil before it could be examined, and this was of such qauntity as to require an entire day's work. Covered with earth for protection over night, some boys visited the spot and in their play jumped on the grave from the bank above, displacing the stones covering the top and breaking into pieces the effigy vase to which reference has been made. This vessel, which was found seven inches east of the left clavicle, hence at the rear of the body, is of porous, shell-tempered ware, écru in color, on which has been applied a whitish slip, ornamented in brown with four connecting triangles at the rim, three continuous bands on the neck, immediately beneath which, surrounding the upper part of the body, is a series of connected spirals, separated below by a field of brown from a band of concentric circles interspersed with horizontal bars, followed by another area of brown above the legs. The vessel, which probably contained "water when deposited in the grave, has been repaired (pl. v), and measures $93 / 8$ in. in height by about $61 / 2$ in. in diameter exclusive of the appendages. The head, which projects midway of the globular body, is round, with short flattish ears; the eyes are indicated by almost indiscernible knobs surrounded with painted bands; the nose is rather prominent, being accentuated by a depression at each side, but is not well defined between its tip and the mouth; the mouth is a shallow, horizontal slit three-quarters of an inch long, and recedes in such manner as to make the animal chinless; the neck is stout, with an almost goiter-like swelling in front and banded with vertical brown lines. Painted diagonal lines of brown extend from the ears to between the eyes, where they meet the brown area that accentuates the nose. The tail, which was made with a roll of clay one end of which was inserted in an aperture pierced in the 

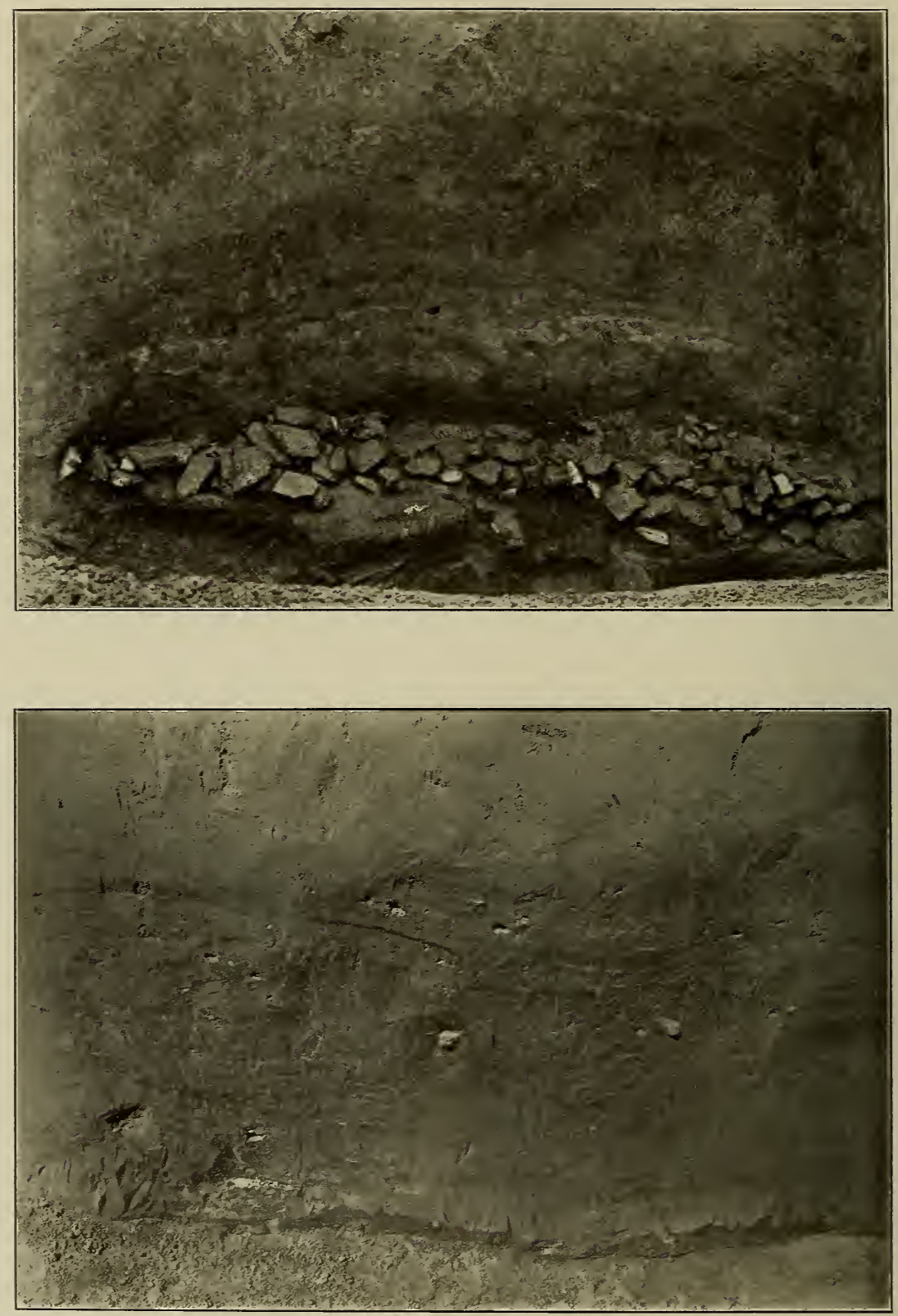

SECTIONS SHOWING STRATIFICATION OF THE EASTERN PART OF THE MOUND 
body before firing and then spread inside by pressure while still plastic, curves upward, but protruding from just beneath the tail is another appendage, of somewhat lesser diameter, which curls upward and then over and under the tail, meeting itself about threequarters of an inch beyond the point of beginning, as if to give the impression of a knot. The tail also has been painted brown, but the pigment is so worn as to have the appearance of mere daubs. The legs of the quadruped are stubby, being only about an inch long, and merge into the body; they were painted with brown stripes, much of which has worn away. What animal the maker sought to represent is not known. The tail suggests an opossum and the head a wildcat.

A vessel almost identical in form and design, but a couple of inches shorter from head to tail, was found in 1890 in a stone grave on the Bosley farm about four miles west of Nashville, Tenn. ${ }^{1}$ So close is the resemblance of the two vases as to lead to the conclusion that they were derived from the same people and that the one found at Nacoochee was intrusive. This Tennessee vessel is here reproduced (pl. vi) through the courtesy of Prof. L. C. Glenn of the Department of Geology of Vanderbilt University, Nashville, Tenn., in which institution this interesting receptacle may now be seen. Another effigy vessel of the same type, from near Lebanon, Tenn., and now in the Peabody Museum of Harvard University, is about eight inches long and of the same height. ${ }^{2}$

Against the shoulder of the effigy vase found by us was a well-preserved conch, from which the columella had been removed evidently for the purpose of transforming the shell into a cup and which was slightly broken from the same cause that resulted in the breakage of the effigy vessel. About the neck of the skeleton

1 G. P. Thruston, Antiquities of Tennessee, pp. I52-I53, Cincinnati, I89o. Ramsay (Annals of Tennessee, pp. 78-79, Philadelphia, I853) says: "The late General Robertson learned from the Indians that more than a century and a half ago, (I665,) the Shawnees occupied the country from the Tennessee river to where Nashville now is, and north of the Cumberland, and that about I 700, they left this country and emigrated north." And again, "In I7I4 Monsieur Charleville opened a store where Nashville now is, occupying as a dwelling a fort which the Shawnee had built there."

${ }^{2}$ Eleventh Annual Report of the Peabody Museum, p. 359, fig. 55, Cambridge, I878. 
were found seven drilled pearls, still retaining some of their nacre. In the soil beneath the skeleton were several small unrelated potsherds and three small rude stone discs which probably had no direct relation to the burial; and the same may be said, no doubt, of a broken ear-plug of pottery found beneath the pelvis. Beneath the feet were three imperfect hammerstones. Outside the grave, six inches from its northwest corner, was an unfinished discoidal stone, similar to many found throughout the progress of the excavation.

Another noteworthy burial (No. 46), evidently that of an adult, was found only a few feet southeast of Burial 39 and at about the same level, namely, I4 ft. 6 in. below the slope of the mound, with the head probably directed southwestward. So wet was the ground in which this grave was encountered that when it was partially uncovered it was necessary to bail away the water that rose to the surface. As in many other instances at Nacoochee, this skeleton was in such an advanced state of decay that it was not possible to follow its course with exactness or even to determine the form of the bones with the exception of the femora, which showed a slightly curved surface, the others having been completely flattened by pressure and become virtually a part of the bark lining of the grave. It was from the position of the femora and the shape of a certain area discolored by decayed vegetal matter that the direction of the skull was conjectured, although the traceable bones covered a space of only 22 inches in length.

The first indication of the presence of this grave, which was not encased in a stone cist, was given by the upturning of a fragment of bark at a point very near water-level, at what proved to be the middle of a layer of this material covering a space of 9 by 15 in., surrounding which, as well as the remains of the skeleton, was the area of black, decomposed vegetal matter, probably also bark, irregular in shape but measuring $3 \mathrm{ft} .7$ in. by $3 \mathrm{ft} .2$ in. maximum. On lifting the preserved bark covering, there was found adhering to the under part a fragment of coarse fabric (fig. 2), and beneath this a piece of matting (pl. vir). Between the matting and the fabric were fragments of thin sheet-copper, the salts of which 



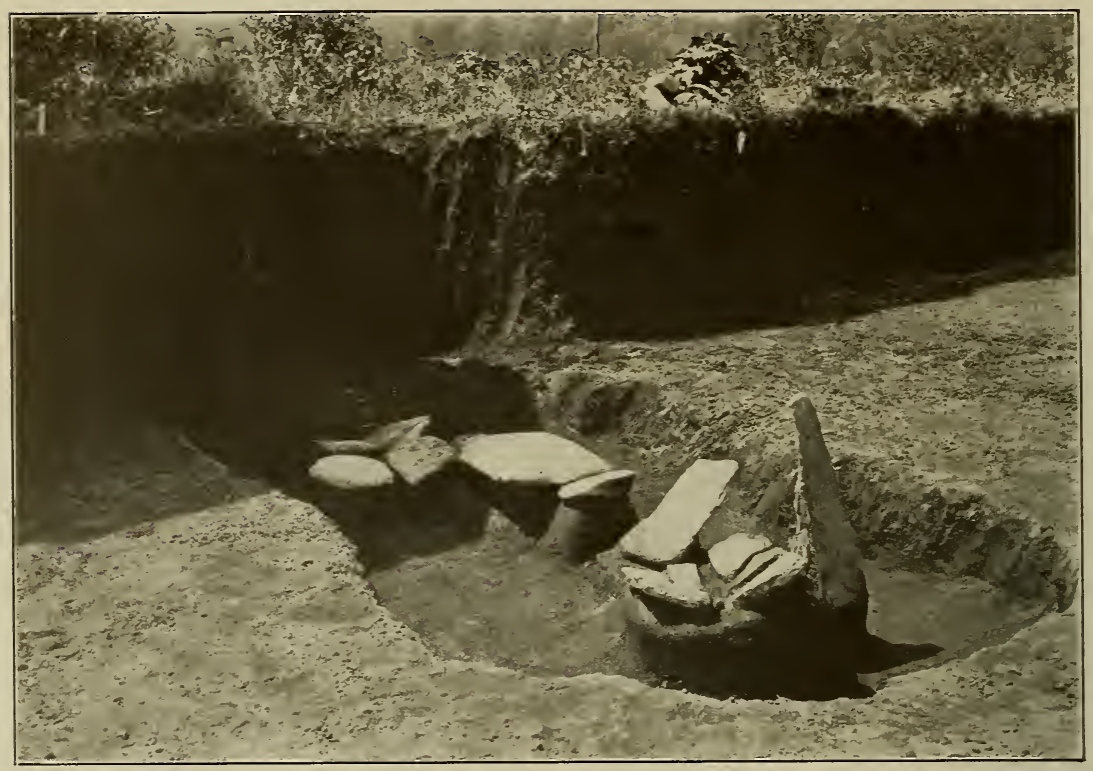

A. STONE DEPOSIT ADJACENT TO BURIAL 6

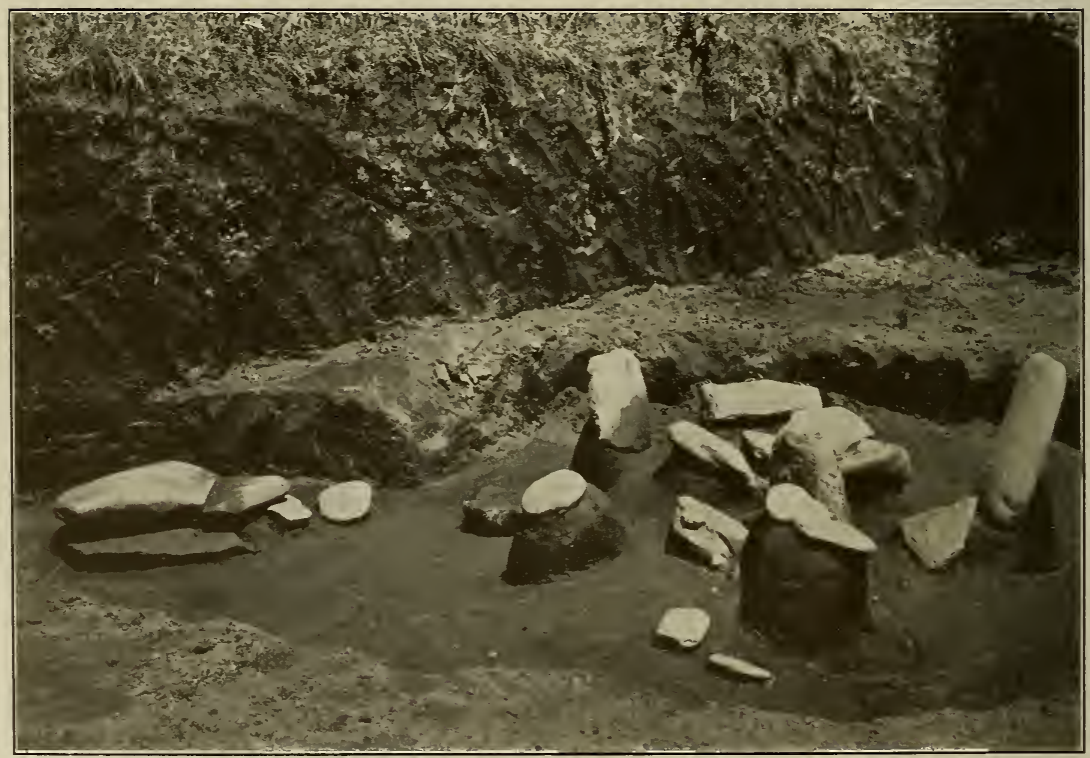

B. STONE DEPOSIT ASSOCIATED WITH BURIAL 9 
had preserved the textiles. This copper ornament was found to be in the shape of the torso and arm of a human figure, but unfortunately it was so disintegrated as to be beyond recovery, except in small pieces. Embedded in the under-surface of the bark covering,

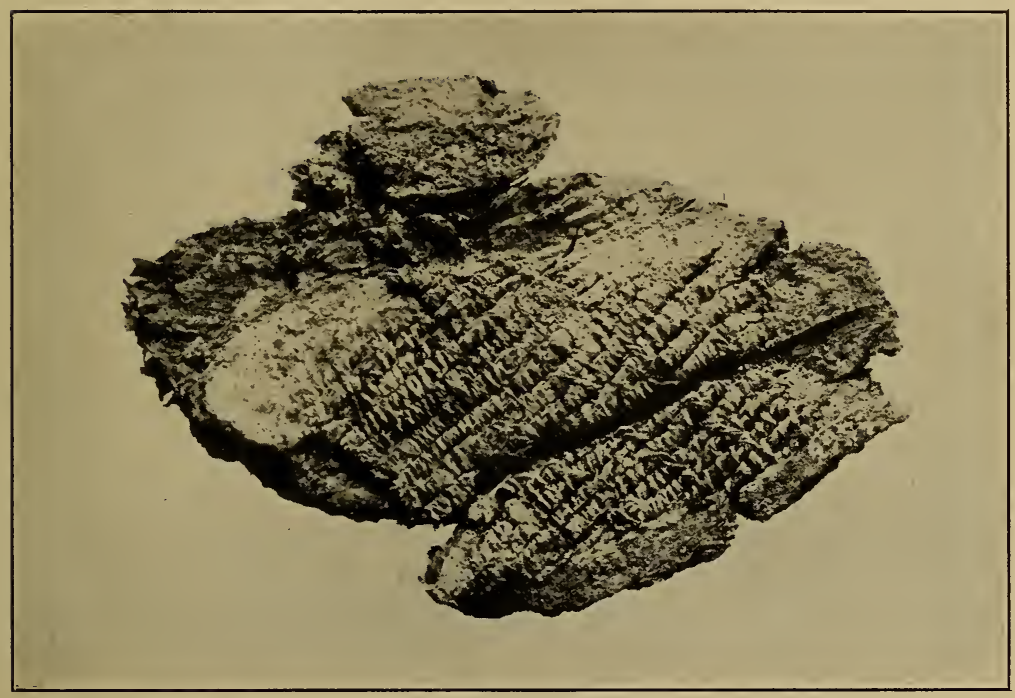

FIG. 2.-Detail of matting with Burial 46 .

a few inches west of the matting, was a copper celt, ${ }^{1}$ with a part of the wooden handle still in place (pl. viII); this likewise had rested on the matting. Beneath the celt, other very thin pieces of a sheet-copper ornament were found, including one representing the claw of a bird, but these also crumbled on exposure. The matting on which the celt rested plainly showed the impression of the implement and its wooden handle, and it was possible to preserve the entire mass. So far as could be determined, the celt and the sheet-copper ornaments had been deposited with the matting and the fabric about the position of the pelvis.

It will be observed that the method of depositing this celt on

1 As employed in this paper the term "celt" must be understood as applying to that class of ungrooved implements, whether of copper or of stone, that had been hafted for use in the manner of axes or hatchets. See pages 82-84. 
the matting in the grave is generally similar to that of the copper implement placed in the stone grave unearthed in 1870 by Captain Nichols near the western limit of the mound, as previously described. The celts themselves, however, differ somewhat in form as well as in size, the Nichols implement (the whereabouts of which is now unknown) being almost a third longer (nearly io in. in length) than the specimen found by us, which is $7 \frac{1}{4} \mathrm{in}$. long, by $\mathrm{I}$ in. wide at the poll and $\mathrm{I} 1 / 2$ in. near the cutting edge. Moreover, the Nichols celt is flaring at the blade-end and squarish at the other, whereas the celt in the Museum of the American Indian, Heye Foundation, tapers gradually and regularly from end to end and is slightly rounded at the poll. Again, the Nichols celt is less than one-tenth of an inch in thickness throughout, while the other averages about three-sixteenths of an inch. A feature in common, however, is the angle at which the two celts were hafted-each in such manner that the under angle formed by the insertion of the blade in the handle (when viewed as shown in pl. viII) is slightly acute. Of course, in the case of the Nichols implement, one can judge only by the impression left by the handle on the blade. Interesting in this connection is the fact that two of the stone celts (p. 83) found by us in the mound show that they had been hafted in the same manner and at relatively the same angle. There is no evidence of lashing on the handle of the copper celt found by us, the two narrow bands crossing the blade being splints from the matting. The recoverable portion of the wooden handle of the celt is well preserved, thanks to its contact with the copper of the celt and the sheet-copper ornaments. While the original length of the handle is unknown, it evidently was quite short in comparion with the length of its blade, if we may judge by the taper of the remaining portion. ${ }^{1}$

The matting found in association with the celt is of diagonal plaiting which forms a pattern in parallel rows. The first strand of each group of four passes under the fourth transverse strand met by it, the second of the group passes under the fifth, the next

1 A similar celt is mentioned and illustrated by Moore, Certain Aboriginal Remains of the Black Warrior River, Jour. Acad. Nat. Sci. Phila., vol. xıI, I905, p. I54, fig. 27. 
.

.




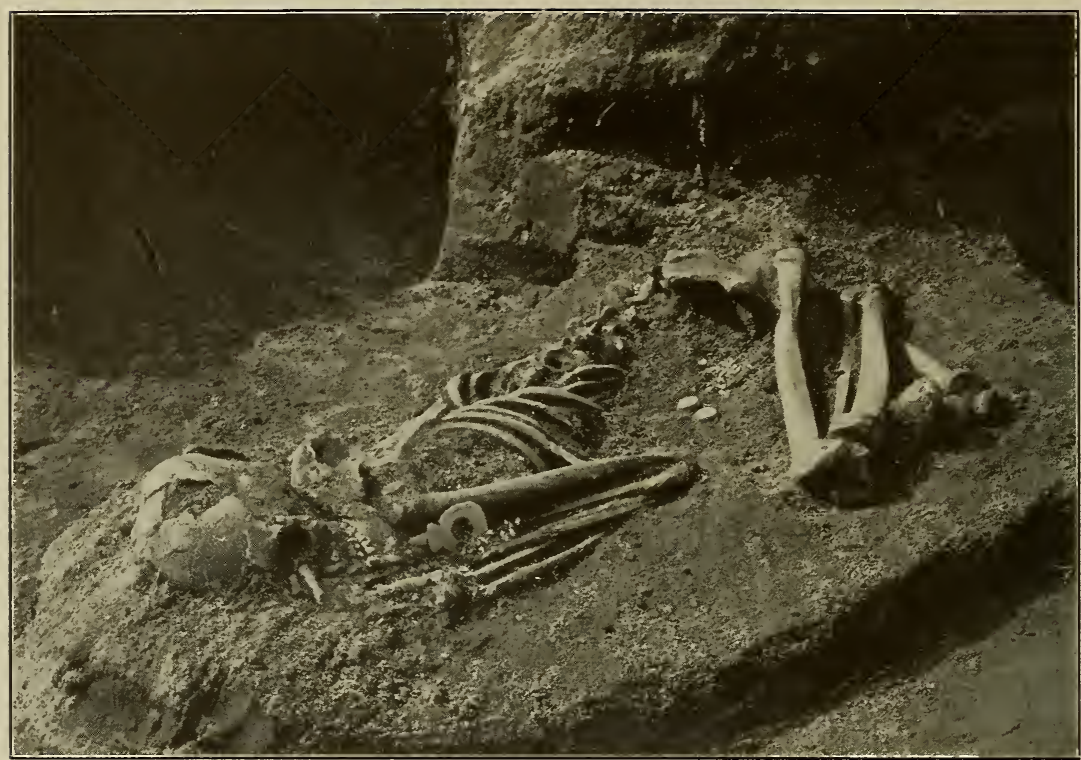

A. BURIAL 2 WITH ITS ACCOMPANIMENTS

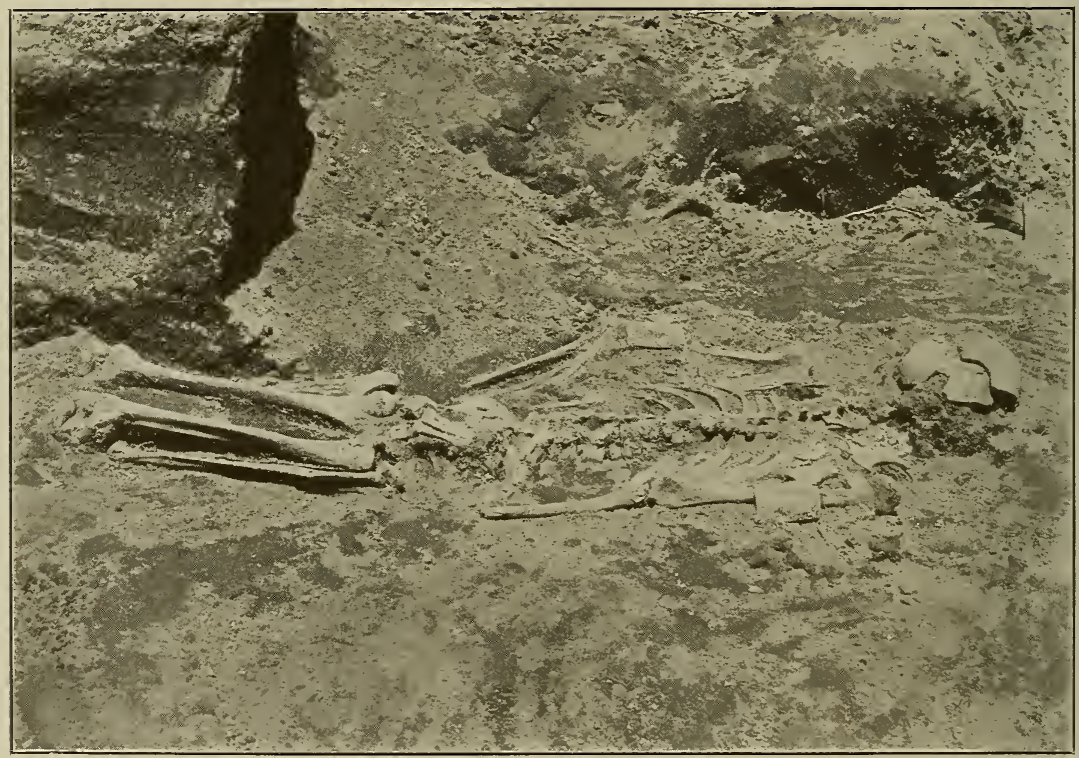

B. BURIAL 3, SHOWING COPPER ARM-BANDS 
the sixth, and so on, but always preserving the under-four over-four order. The strands or splints, which average an eighth of an inch in width, were probably rather loosely plaited, and are of tough fibrous material like split cane. Adair's description of the Cherokee baskets is generally applicable to the matting found by us. $\mathrm{He}$ says: "They divide large swamp-canes into long, thin, narrow splinters, which they dye of several colours, and manage the workmanship so well, that both the inside and the outside are covered with pleasing figures." 1

There is no indication that the specimens of matting found by us were ever colored, in which respect they differ from the basketry found by Captain Nichols and described by Jones. Another point of difference in the textile found in the two parts of the mound is the technique, the Nichols specimen ${ }^{2}$ showing a rectangular, irregular plaiting so far as it is possible to determine from such a small example.

The fragment of textile found with Burial 46, shown in fig. 2, has been examined by Miss Mary Lois Kissell, who pronounces it to consist of a binding element of twisted two-ply fiber on a foundation also of twisted but different fiber. The binding element is wrapped around the foundation in coils, the segments thereof being stitched at intervals of about half an inch. The fabric has been so coated with copper salts that its true character is determined only with difficulty, nor can we hazard a reasonable conjecture as to the use to which it was put, unless it served as a bag. No indication of coloring is traceable.

Another stone grave (Burial.53) was encountered in the eastern portion of the mound, at a depth of 16 feet (pl. Ix). The skeleton, which lay flexed on the right side, was directed N.E.-S.W., the skull toward the N.E. The body had been covered with earth, on which seven large flat stones were placed, and on these the bowlders, the whole being covered with bark. Only one of the flat stones was on edge when the grave was uncovered. The skeleton had been laid on bark, which had almost completely decayed. Resting in the

1 James Adair, History of the American Indians, p. 424; London, I 775.

2 Jones, op. cit., p. 225 , pl. vi, I. 
bend of the left arm was a stone celt, which lay parallel with the axis of the body, the cutting end toward the feet. On the poll of the celt were Io small arrowpoints, and at the side a number of large shell beads and the wooden core of an ear-ornament (pl. $\mathrm{x}$ and fig. 63 ). Beneath this celt and its accompanying objects were another celt and 35 more arrowpoints, the second celt lying immediately beneath the other and pointing in the same direction. As in the case of the others, these arrowpoints rested on the blunt end of the celt which they accompanied. Over this deposit of celts, arrowpoints, and shell beads, was a hard black incrustation which formed a shell-like pocket in which the objects lay. Northeast of this deposit, and almost touching it, was another small depression, similar in material, coated with a layer of greatly decayed shell or bone. In the center of this pocket were a number of lobe-like elevations, covered with white material similar to the decayed bone or shell described. Still another pocket was found northeast of and almost touching the skull; in it was a fragment of a shell. bracelet. Projecting from beneath the skull were a large stone celt and a smaller one (pl. LvI, $d, e$ ), the latter perforated at the narrower end.

Under one of the stones covering the grave, pieces of the shells of hickory-nuts, chestnuts, and squash seeds were found; and just above one of the grave-stones was a large arrowpoint.

No other burials in stone-box graves were found in the mound, the deposits of stones in association with burials nearer the summit not being regarded as such. These will be described later.

The occurrence of these graves and their contents, not to mention others, on both the eastern and western bases is evidence of the unity of culture of the inhabitants of Nacoochee long before the mound had reached its ultimate height, for, as will be shown later, the earthwork was no doubt in process of erection during a long period. The presence of such mortuary objects as copper celts, matting, a sheet-copper ornament, etc.,-objects not found in the upper portions of the mound where conditions for their preservation were more favorable-indicate more or less of a change in the culture of its inhabitants, due possibly to the influence of civilization. 


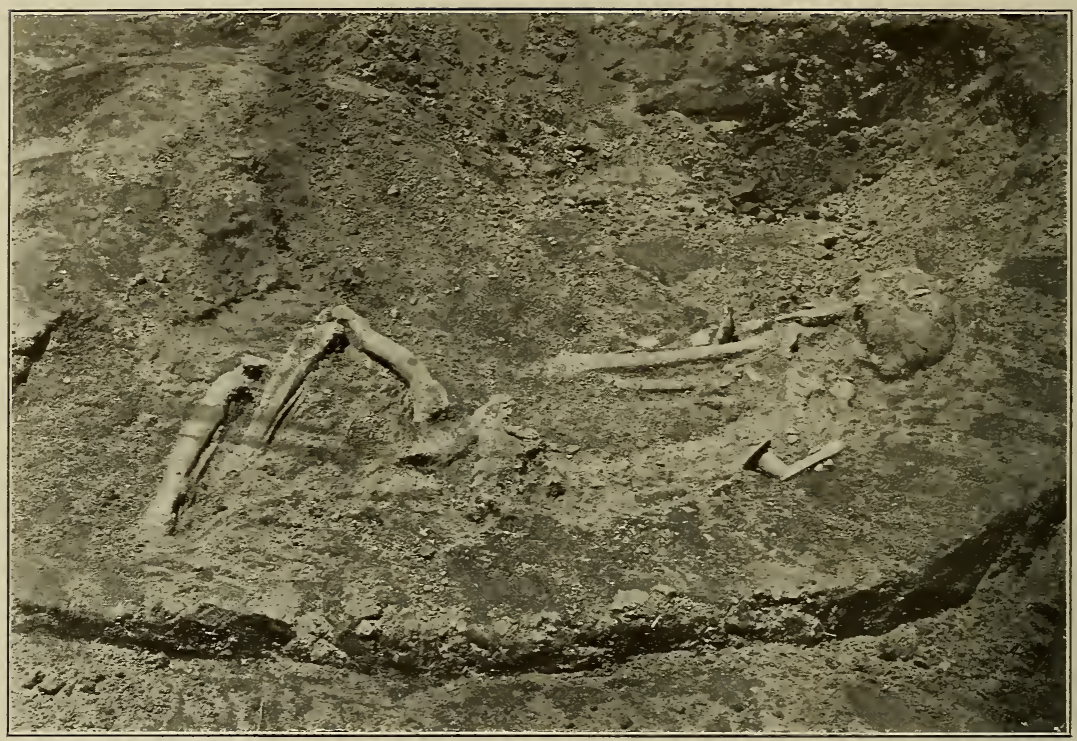

A. BURIAL 4 WITH ITS ACCOMPANIMENTS

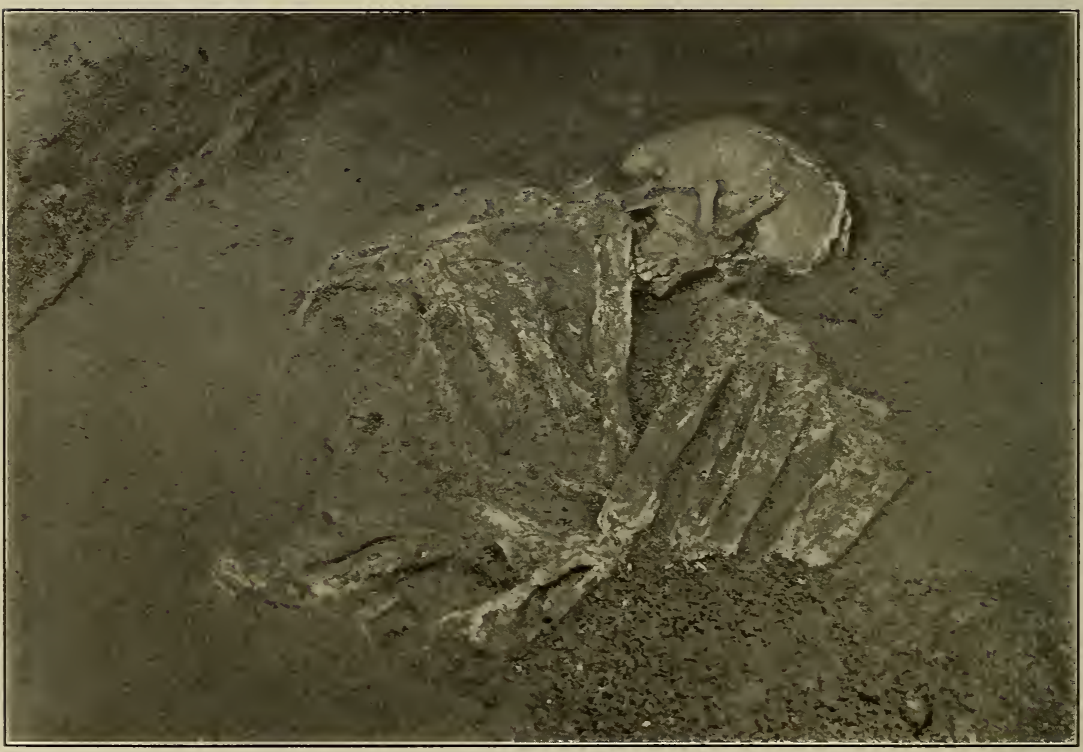

B. GRAVE 47 , AN EXAMPLE OF A GREATLY FLEXED BURIAL 
We will now characterize the features pertaining to the construction of the mound as exhibited by the excavation, especially of the eastern side (in which section the work was particularly concentrated), leaving the other graves for consideration later.

\section{FIRE-PITS}

It has already been shown that about two feet of the summit of the mound had been removed in recent years. Human bones are said to have been found in the process of removal, but of their character nothing is now known, and of course the conditions incident to the summit itself are no longer possible to determine.

In removing the uppermost four feet of the mound as it existed when the work was commenced by us, we discovered the remains of an extensive fire-pit, the top of which reached to within six or seven inches of the surface of the mound, north of its center. This pit, shown in plate XI, aggregated $8 \mathrm{ft} .9$ in. in diameter. Careful observation of the pit showed that it actually consisted of a series of smaller pits, more or less fused, that had been used successively; then as the earth of the mound had been renewed from time to time and the fire-pit then in use had been covered with earth, another was formed above. This earth covering of the successive pits had burned red, as was always the case when fire had come in contact with the black soil of the mound, as before described. At a depth of $4 \mathrm{ft} .3$ in. beneath the surface, directly under the firepit, was a thin layer of charcoal, and four inches below this was another, each extending a foot beyond the limit of the fire-pit at the south and seven feet beyond it at the north, as if the remains of a shelter, or of two shelters, that had been erected on the summit of the mound at the time it had reached only to that height. These thin charcoal strata are faintly visible at the very bottom of the vertical wall in which a section of the fire-pits is shown. Immediately above them, showing in the illustration as a thick, dark stratum below the lighter material of the fire-pits themselves, were several ill-defined strata of bright-red clay. The fire-pits themselves were completely filled with gray wood-ash, so indurated as to be almost of the consistency of cement concrete, containing small 
pieces of charcoal and stone, and a few potsherds, including the crested head of a bird that evidently had formed part of a smoking pipe, as well as a pipe of steatite. Near the southern border of the fire-pits was a post-hole, dug in recent times through the hardened ash.

We have already noted that, according to Cherokee tradition, a sacred fire was kept burning on a peculiar hearth excavated in the center of the earthen floor of the town-house, which was built on a mound. It would seem that the great fire-pit near the middle of the summit of Nacoochee represented the remains of one of these sacred places.

Throughout the mound, at varying depths, were numerous other evidences of fires, in some cases very small, in others occupying from one to two cubic feet or more, and in every instance filled with gray ash and wholly or partly surrounded with reddened earth. These fire-pits were significant in that by far most, if not all, of them had been made in the surface of the mound as it existed at the time, showing that the mound had been formed by gradual accretion.

A few feet northwest of the large fire-pit, covering an area approximately $8 \mathrm{ft}$. square, were the charcoal remains of a layer of reeds lying rather regularly in an east-west direction, with burned poles, about $2 \frac{1}{2}$ in. in diameter, extending in the same direction as well as transversely. Over parts of the charred mass, which was 2 to 3 in. in thickness, was a layer of red-burned earth of about the same thickness as the charcoal, and under other parts was a similar layer, the whole evidently being the remains of a shelter of pole-and-cane construction.

Another fire-pit, in the southwestern section of the mound, was found $4 \mathrm{ft} .2$ in. below the summit; it was 22 in. in circumference at the top, but tapered to about Io in. at the base, and was $2 \mathrm{ft}$. in depth. The top of this fire-pit, judging from the surrounding soil, seemed to have been at the level of the summit of the mound at the time the pit was in use. The pit was entirely filled with a mixture of red-burned earth and charcoal. From its top downward, on both sides, extended a stratum of gray, sandy clay, as if from 



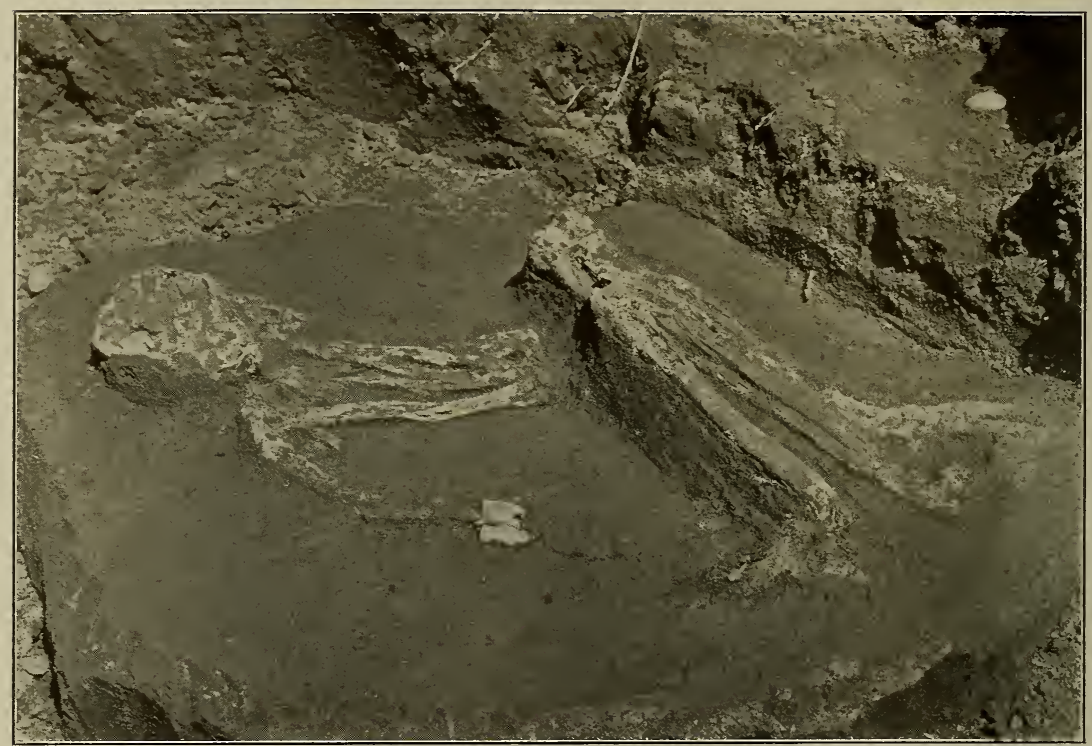

A. BURIAL 48

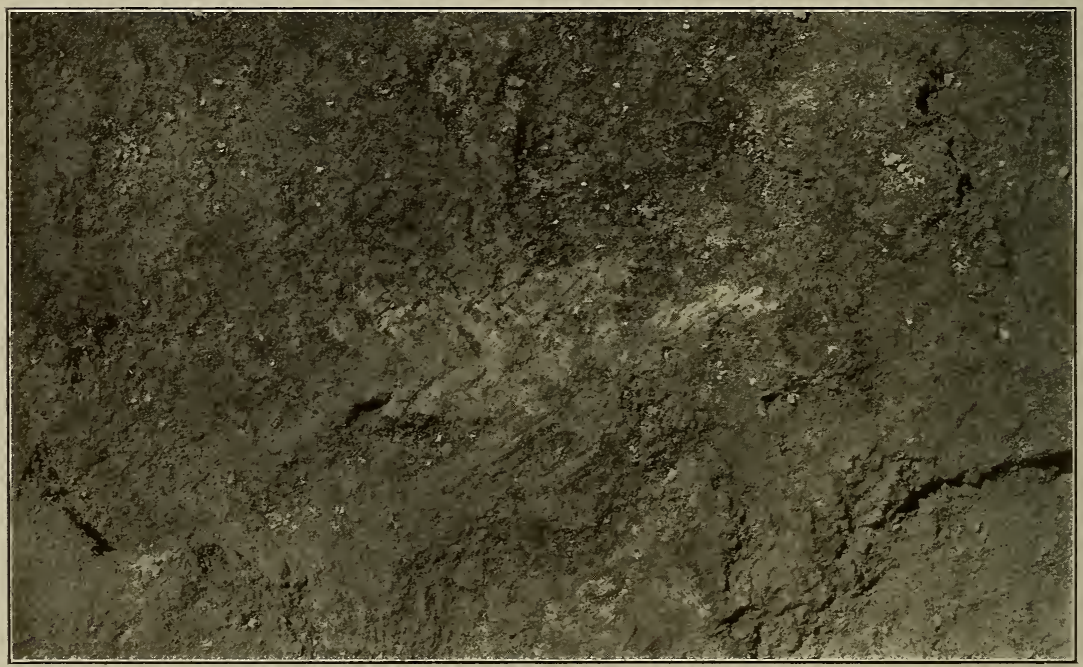

B. TRACES OF MATTING COVERING BURIAL 50 
the river-bed, for a distance of five feet, or about twelve feet in all. Beneath and around the pit were seven stones, mostly flat, some roundish, ranging in weight from 15 to 40 pounds. No sign of bone or of artifacts was in or near the pit. In this part of the mound there was great paucity of sherds or other refuse.

In addition to a fire-pit found in association with Burial ro (see p. 4I), there was another, $5 \mathrm{ft}$. 8 in. northwest thereof, measuring about $\mathrm{I} 3 \mathrm{in}$. in depth by $8 \mathrm{in}$. in maximum diameter, the top being 19 in. below the mound surface. Spreading from the top of the pit in all directions was a stratum of red-burned earth mingled with ash, two to three feet in thickness. This stratum evidently marked the surface of the mound at the time the fire-pit was in use.

Still another fire-pit was uncovered in the adjacent field, southeast of the mound proper. This pit was 7 in. beneath the surface and was $3 \mathrm{ft}$. deep. It extended in a N.E.-S.w. direction, was $21 / 2$ ft. long, 20 in. wide at one end and 12 in. at the other, and was almost filled with stones, none larger than eight inches in greatest dimension, mostly flattish, and all showing the effect of fire. Beneath the stones was charcoal, and scattered through the earth adjacent to the stones were numerous potsherds and flecks of charcoal. Also beneath the stones was a bone of pasty consistency measuring I by Io in., so decayed as to be beyond identification.

At the eastern base of the mound another fire-pit was unearthed, with three flat stones on top and charcoal and red-burned earth beneath. Both in and under this deposit were many fragments of incised and plain earthenware, some quite large. Some of the charcoal found preserved the shape of poles or small logs, $21 / 2$ to 3 in. in diameter and 2 to $3 \mathrm{ft}$. long. The extent of this fire-place was $6 \mathrm{ft}$. in length by 15 in. in thickness. The bottom was 20 in. above the base of the mound, as indicated by the undisturbed brownish clay floor. It is not improbable that this place, as well as the one last mentioned, was used for firing pottery. Beneath the fire-place, one foot above the mound base, was a stratum of reddened earth and fine charcoal mixed, in thickness from 8 to io in.

A fire-place $\mathrm{I} 2$ by $\mathrm{I} 6$ in. was discovered in the northeastern side of the mound, $6 \mathrm{ft}$. Io in. below the surface. This consisted 
of three flat stones, one still on edge, between them being a mass of charcoal; beneath was a layer of yellow clay, the position of which showed that the fire-place and the superposed earth had settled about six inches from its original position. This fire-place was about six feet south of the point where Burial 70 presumably lay. Extending from a point just beneath the fire-place southward for a distance of three feet was a stratum of charcoal mixed with animal bones and potsherds.

\section{STRATIGRAPHY OF THE MOUND}

The evidence afforded by the fire-pits was not the only indication of the gradual building of the mound and of its occupancy at different levels during the process, for throughout the excavation the face of the trenches gave ample testimony that such was the case, the periodical building-up and widening of the earthwork being easily read from the stratification of the successive accretions. Especially was this determinable as the depth of the excavation of the eastern side increased until it reached the original base, $19 \mathrm{ft}$. below the summit, or nearly $2 \mathrm{ft}$. lower than the surrounding field.

A typical section exposed $12 \mathrm{ft}$. east of the eastern rim of the summit and $12 \mathrm{ft}$. in depth showed the following character:

Commencing at the bottom, above an undisturbed sand layer ${ }^{1}$ which contained no charcoal, was stiff, moist, clayey earth, very compact, for a thickness of 22 in., mingled with small fragments of what appeared to be iron-stained clay. Next above was a layer of red-burned earth, 18 in. in length and 3 in. thick at its widest or central part. Above this for an irregular few inches the clayey earth was darker in color. Next, for a thickness of six feet, was a similar deposit of thick, clayey earth, in which were many specks of charcoal; the top of this stratum was eight feet above the sandy base of the mound, and its upper two feet was particularly rich in charcoal, with here and there a particle of red-burned clay or earth. The next four feet consisted of darker soil like that of

${ }^{1}$ It should be remembered that the entire field surrounding the mound has been covered by the overflow of the river even within recent years. It is said that the precipitation in this section of northeastern Georgia is as great as that of any part of the United States. 


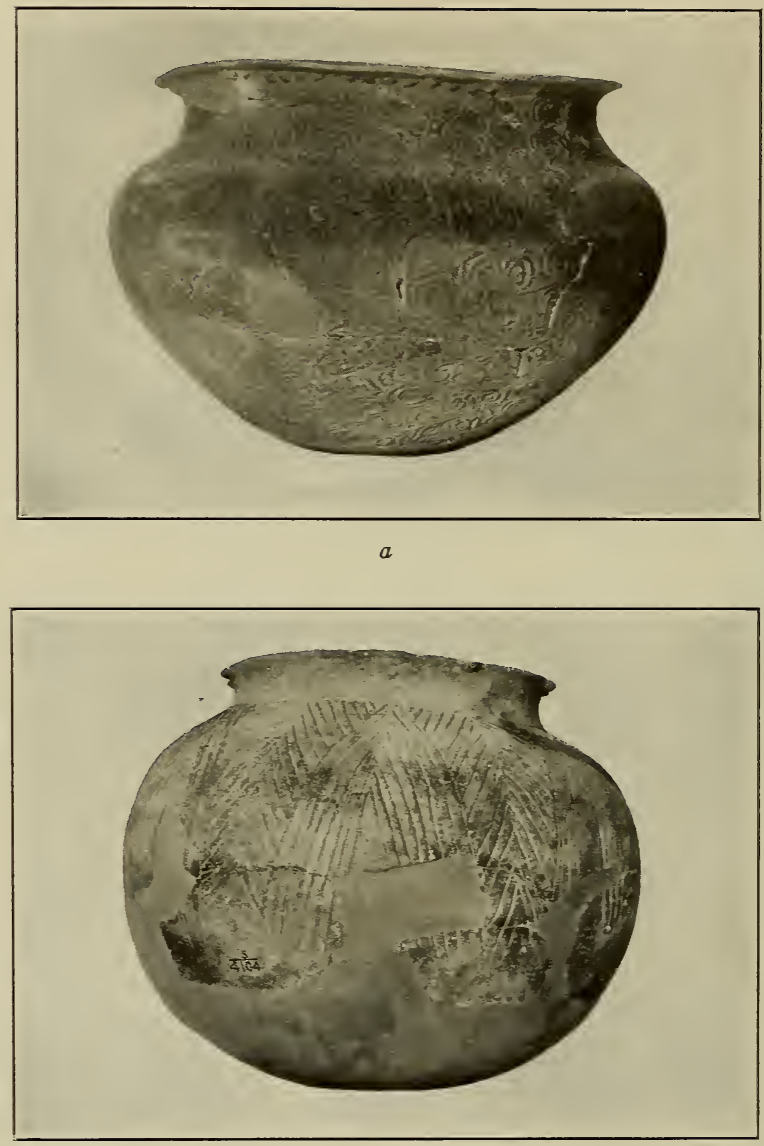

$b$

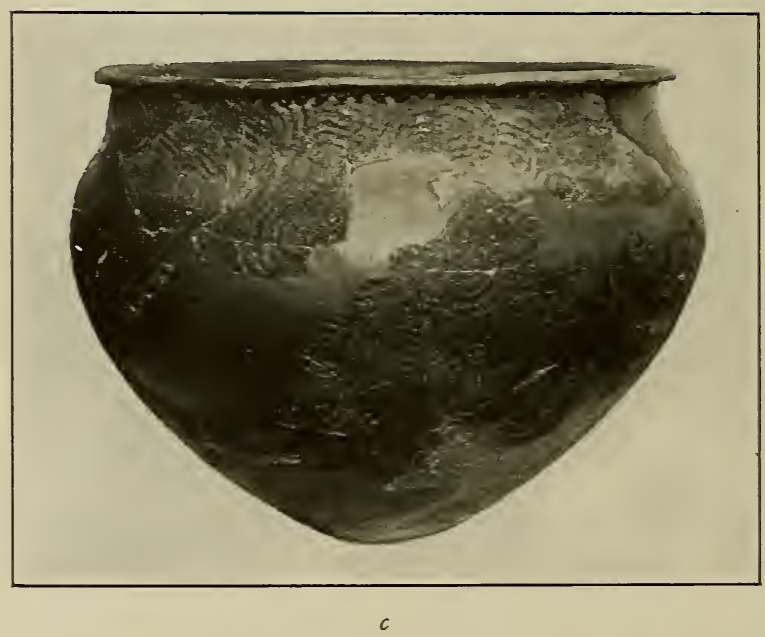

EARTHENWARE JARS FROM NACOOCHEE (RESTORED) 
the field, with a fleck of charcoal and bone appearing at intervals. The stratification was not well defined, but was sufficiently plain to show that the dip was toward the outer base of the mound, and seemed to indicate here, as in the face of other trenches where similar observations were made, that the mound had been built at intervals.

Throughout the exposed face of the deep trench in the eastern side, small fragments of earthenware were found, all belonging to the three principal styles of Nacoochee pottery to be described later. No one of these was confined to any particular level or depth, indicating that the stamped ware with straight-line, rectangular, or curvilinear patterns, as well as the incised ware, was synchronous in manufacture. The same may be said of the quantities of sherds found beneath all the slopes of the mound from top to base.

Later in the work, when the excavation had entered the eastern side until its face had reached a depth of $\mathrm{I} 7 \mathrm{ft} .2$ in., Mr Pepper observed what had evidently been a smaller mound within the great one. This measured $27 \mathrm{ft} .9$ in. in length and $5 \mathrm{ft} .3$ in. above a stratum of yellow clay and sand under which burials were found, and which, as nearly as could be determined, had been laid down on the original surface of the ground.

This lesser mound was composed of black soil and yellow sand, so intermixed that the section presented a cloudy appearance, strongly contrasting with the dark-brown soil above. The top of this small mound was I I ft. below the summit of the great structure, the space between being filled with a semistratified mass whose lines dipped away from what had been the summit of the lesser mound. This overlying deposit was so broken with small pockets of sand and other materials that measurements were not practicable, but the lines conformed with the general contour of the small mound for some distance on each side thereof, then broadened until they became almost horizontal.

The yellow clay at the base, above referred to, varied from 5 to 7 in. in thickness and extended northward from the east-west center line for a distance of $\mathrm{I} 3 \mathrm{ft}$.; northward farther beyond this point the stratum became sand, whose thickness varied from 5 to 8 in., ending $2 \mathrm{I} \mathrm{ft}$. beyond the clay. South of the east-west center 
line the same yellow stratum continued, becoming thinner as it extended southward until it reached an ultimate length of $20 \mathrm{ft}$.; hence the basal yellow clay-sand deposit was $54 \mathrm{ft}$. in total length.

Under and through the clay and sandy base referred to were five pockets, the measurements of which are given in the accompanying

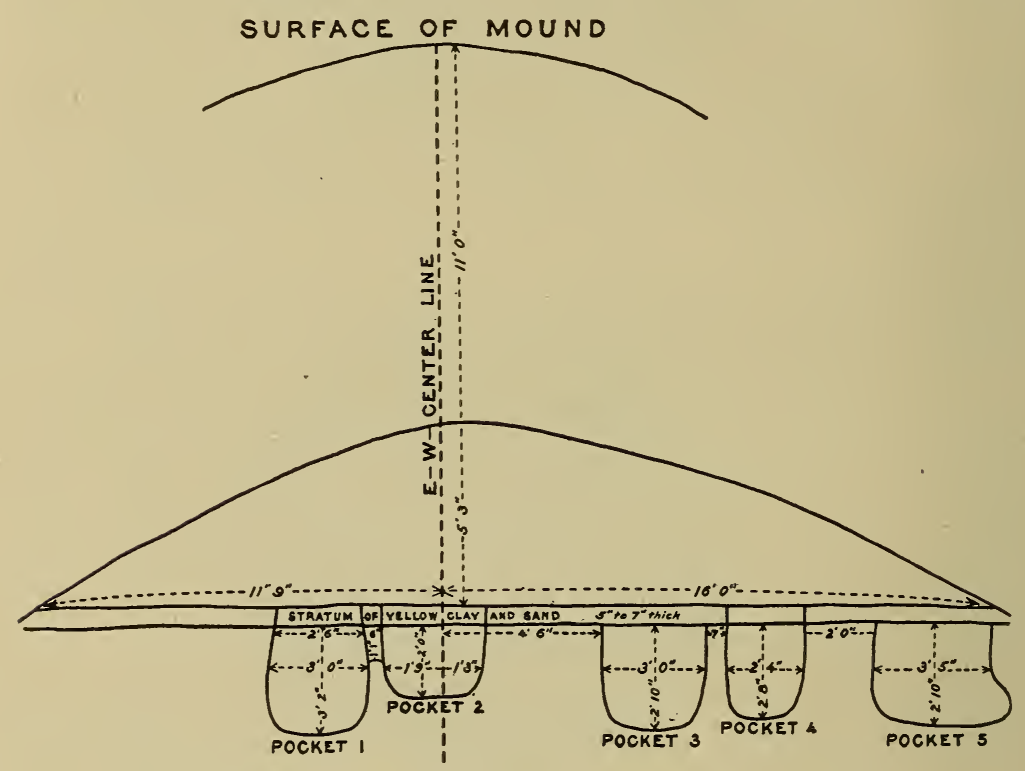

FiG. 3.-Pockets beneath the lesser mound within the larger one.

sectional drawing (fig. 3), and whose character and contents were as follow:

Pocket I. - This pocket had been cut through the yellow-clay stratum and was crossed by several thin layers of sand. At the bottom were charcoal and burned bones. The center of the deposit was $2 \mathrm{ft} .2$ in. s.s.w. from the knee of Burial 54; it was I ft. 8 in. in diameter, 2 in. in thickness, and I ft. 2 in. below the level of the skeleton. Most of the fragments of bones seem to be non-human, but some of them, notably a piece of skull having the appearance of part of an occiput, may have been human. Owing to the fact that there was a portion of the yellow-clay stratum between pockets I and 2, it would seem that these holes had been dug at different 


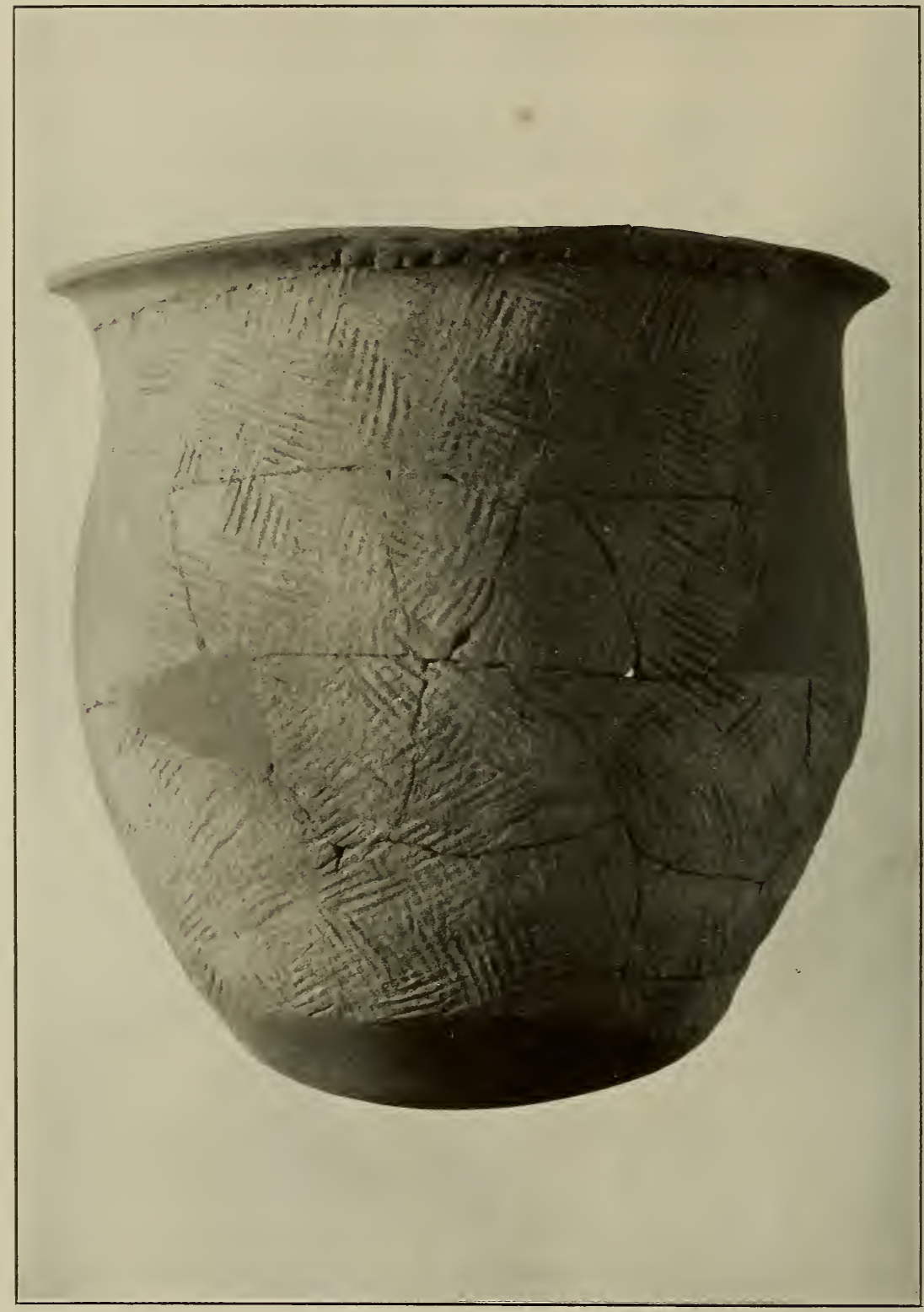

EARTHENWARE JAR FROM NACOOCHEE (RESTORED) 



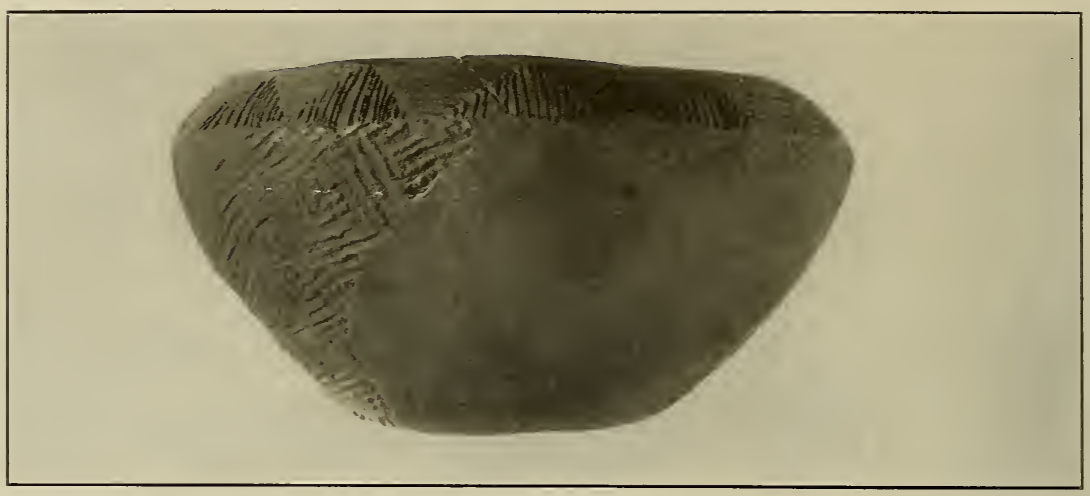

$a$
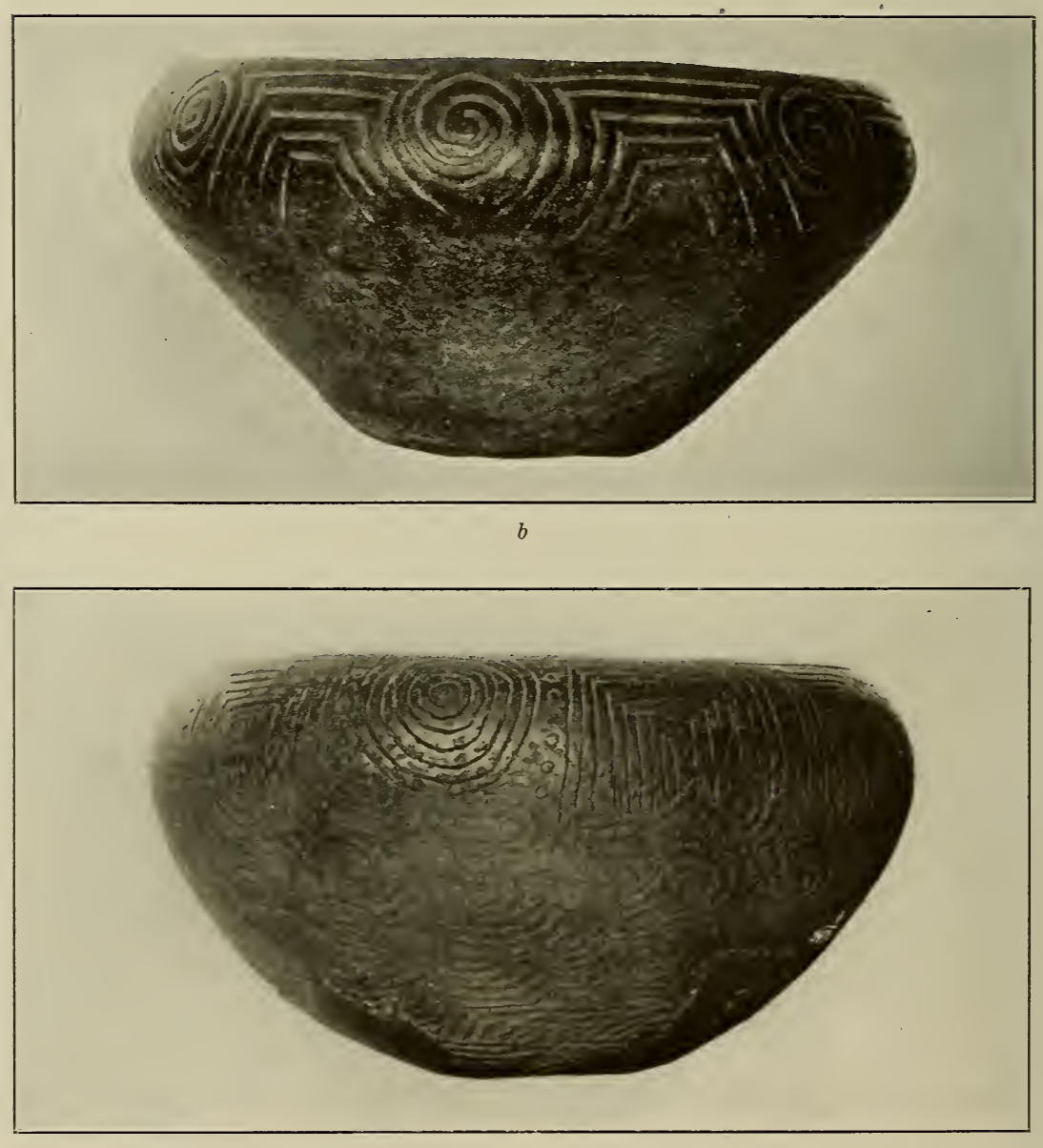

c

EARTHENWARE BOWLS FROM NACOOCHEE (A AND C RESTORED) 
times; if so, the bone deposit referred to had no association with Burial 54.

Pocket 2.-Cut through the stratum of clay and adjoining No. I on the north, was a layer of yellow clay 6 in. wide, between the upper edges of Pockets I and 2, but which became joined I3 in. below the stratum. This pocket was not stratified, but it contained charcoal mixed with the earth and sand, as well as the remains of the skeleton of an adult (Burial 54) which had been interred in a N.E.-S.W. direction, headed N.E., with body flexed, as determined by the relative positions of the pelvis, leg-bones, and skull; all in very fragmentary condition. The grave had been lined with bark. This grave was $18 \mathrm{ft}$. below the summit of the mound.

Pocket 3.-As shown in the sectional sketch, this pocket was covered by the undisturbed clay stratum, and as in the case of Pocket I, it was stratified with light and dark sand. No objects were found in this pocket, nor any signs of a burial, but owing to the fact that the human remains found in the other pockets had almost disappeared through decomposition, it is possible that there had been a burial in this one also. If the burial of a child, it would have been one of only two found in the lower section of the entire mound.

Pocket 4.-This had been cut through the yellow-clay layer and contained a strong admixture of the yellow clay and earth. Found therein were the greatly decayed remains of a skeleton (Burial 55), probably of an adult, represented only by a discolored area in which were parts of a skull and teeth, the former at the northeastern end of the grave. The burial was without accompaniments and lay $18 \mathrm{ft}$. beneath the mound summit.

Pocket 5.-The top of this pocket lay beneath the yellow stratum, which here was of clay and sand. The contents consisted in part of a mixture of yellow clay from the stratum, and soil, especially in the southern upper corner, together with sand and earth containing a sprinkling of charcoal. Also found in this pocket were a legbone and part of a pelvis - all that remained, in recognizable form, of the skeleton of an adult (Burial 56). No artifacts accompanied these remains. 
Adjoining Pocket 5 and extending six feet north of it, beneath the yellow stratum (which here was wholly of sand), was a discolored area containing charcoal, some yellow clay, and a few small, dissociated pieces of bone, probably animal. This discolored deposit was $2 \mathrm{ft}$. Io in. in thickness. In the central part of the area, within a foot of the northern side of Pocket 5, a small stone celt was found. The earth in this deposit exhibited no discoloration such as was usually seen when a burial had been present. South of Pocket I, beneath the sand stratum which formed the continuation of the yellow-clay layer, the ground was discolored and likewise contained some charcoal.

Another section was carefully noted by Mr Pepper in the northeastern part of the mound at an average depth of $17 \mathrm{ft}$. Here the base consisted of a stratum of stones, mostly rough pieces but also some bowlders, none very large, extending N.N.E.-S.S.w. for a horizontal distance of $25 \mathrm{ft}$. 6 in., with a thickness averaging $2 \mathrm{ft}$. The stones rested on a layer of bark, some of the pieces of which

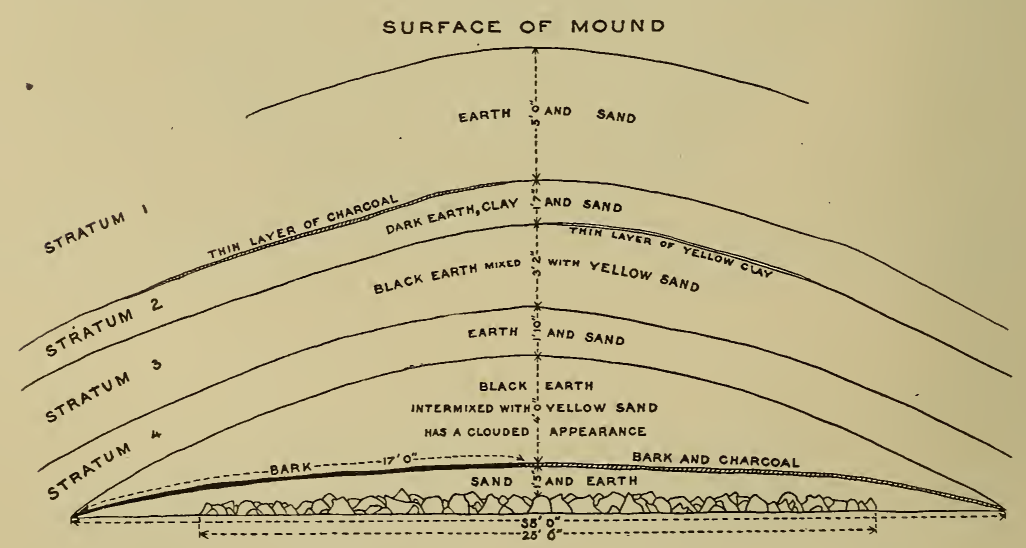

FIG. 4.- Section of the mound in its eastern portion, showing stratification.

were an inch in thickness, which in turn lay on a five-inch stratum of yellow sand, below which was a mixture of sand, clay, and charcoal. This seemed to have been the original level of the ground. (See pl. XII.) At the northern end of and about 18 in. lower than the stone layer, a fragmentary jar with stamped decoration was 



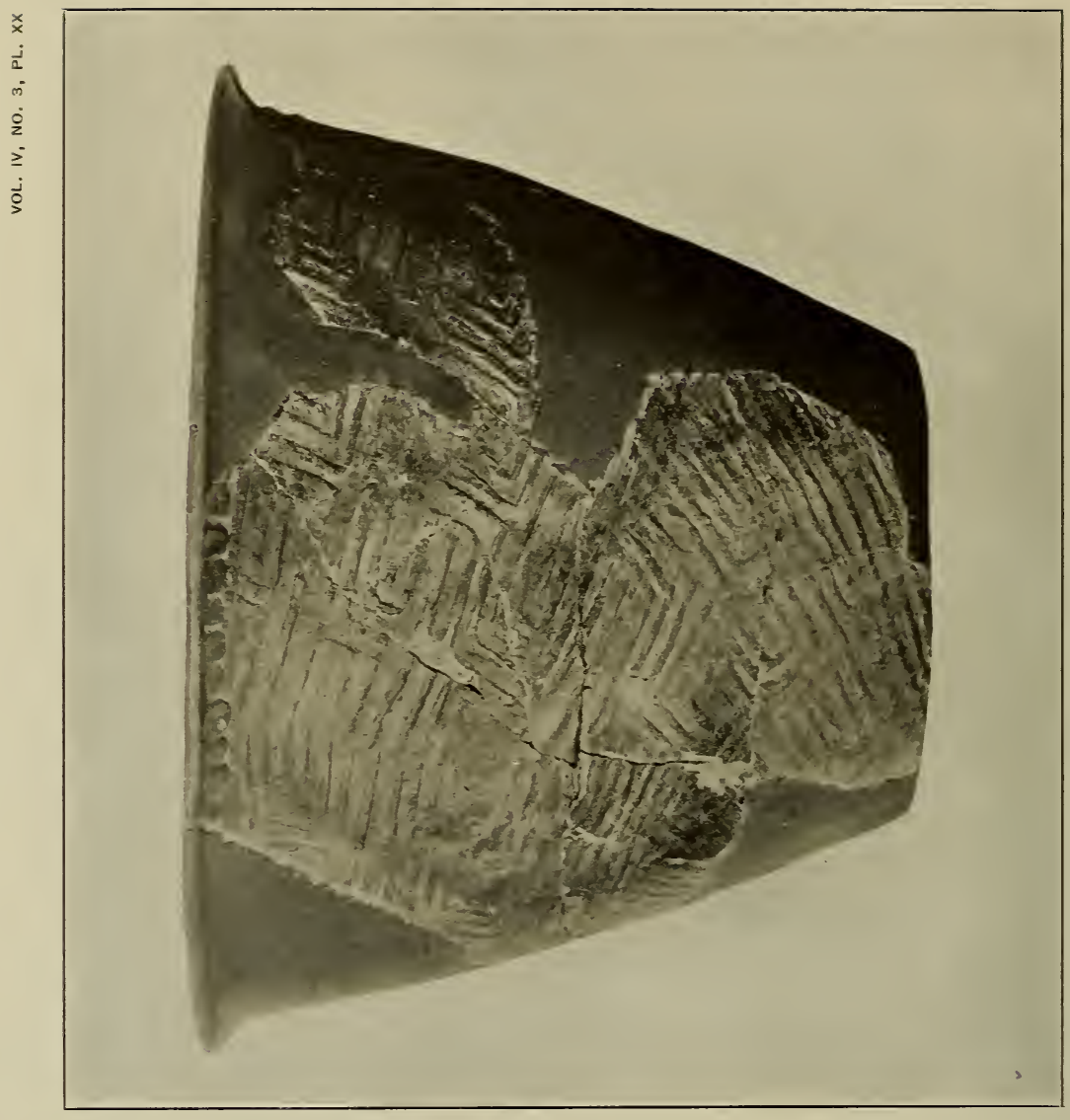

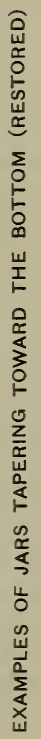


found, the largest sherd being $\mathrm{I} 8 \mathrm{ft}$. below the surface of the mound. This fragment was surrounded by a mass of charcoal and animal bones, as well as portions of other vessels. Directly over the stones was a layer of bark and charcoal, curved in section, the ends of the deposit resting on the end stones and extending about five feet beyond them in each direction, while the central part was a foot above the stones, with earth between. The appearance of the strata above the stone layer was generally similar to that of the exposed section containing the burial pockets previously described; that is, they indicated a small mound whose base rested on the layer of yellow sand. The composition of this lesser mound above the stones and the upper bark deposit was black earth intermixed with yellow sand, giving it a cloudy appearance; it was $4 \mathrm{ft}$. high, conical in section, the sides tapering rather regularly until they reached the base formed by the upper bark layer, which was $35 \mathrm{ft}$. in extent. Next above this mound-like deposit was a stratum of sand and earth, I ft. Io in. in thickness at the apex, but broadening toward the bottom. The next stratum above consisted of black earth mixed with yellow sand, $3 \mathrm{ft} .2$ in. thick at the apex, with a thin layer of yellow clay extending from the apex down its northeastern slope for about $121 / 2 \mathrm{ft}$. Next above was a layer of dark earth, clay, and sand, almost level at the center (where it was I ft. 7 in. in thickness) and toward the southwest, but still sloping considerably at the northeast. This stratum was marked along the top of its southeastern half by a thin layer of charcoal. Above this, to the summit of the mound, the deposit consisted of earth and sand to a depth of $5 \mathrm{ft}$. The stratigraphy of this lesser mound and of the subsequent fillings above is shown in the accompanying sketch (fig. 4).

\section{STONE DEPOSITS}

Allusion has been made to deposits of stones encountered throughout the excavations, some of which had the appearance of graves.

Perhaps the most significant of these was uncovered a few feet east of the center of the summit and four feet deep. The stones were not arranged in any particular order (pl. XIII, $a$ ), and they did 
not have the appearance of once having formed a box grave like the cists uncovered at the lower levels of the eastern side of the mound. No human remains were found within the space covered by the stones, but scattered at intervals, especially near the eastern end (the stones had an E.-W. trend) were several fragments of bones, presumably of a deer. Ten inches west of the stones, however, was the skull of an adult (Burial 6), all of whose bones were completely flattened into a pasty mass; yet it was possible to determine that the remains had been placed on the right side, with the head directed eastward and with knees flexed. No artifacts accompanied the burial, and there was no direct evidence that the stone deposit and the burial were related. Above the skull was an eastern pocket of the great fire-pit before described, which at this point was 19 in. in diameter at the top and 18 in. in depth, the bottom extending to within 18 in. of the skull, but evidently the pit had no association with the burial. The pit contained wood ash, particles of charcoal, and small fragments of red-burned earth. Immediately above the mouth of the fire-pit was a clay flooring, two inches in average thickness and extending a .couple of inches beyond the rim of the pit at each side.

Two feet north of the skeleton was a mass of red-burned earth intermixed with charcoal, extending throughout which, for a length of $3 \mathrm{ft}$., was a charred beam or pole, $\mathrm{I}$ in. to $2 \frac{1}{2} \mathrm{in}$. in diameter, over which, separated by a thin layer of red-burned earth, was a mass of charred grass, in places half an inch thick, for the greater part laid longitudinally. It may be conjectured that this burned material represented the remains of a thatched house or shelter that stood on the mound at a time its summit was below the present level.

Generally similar to this stone deposit was another, found $4 \mathrm{ft}$. 6 in. below the summit, the stones being arranged as shown in plate XIII, $b$. The extreme length of the area covered by the stones, which extended in a N.E.-S.w. direction, was $9 \mathrm{ft} .7$ in., and the maximum width $5 \mathrm{ft}$. Under the upright stone showing in the rear center of the photograph was a rough, flattish stone, disintegrated by fire, on and about which was a mass of charcoal and 


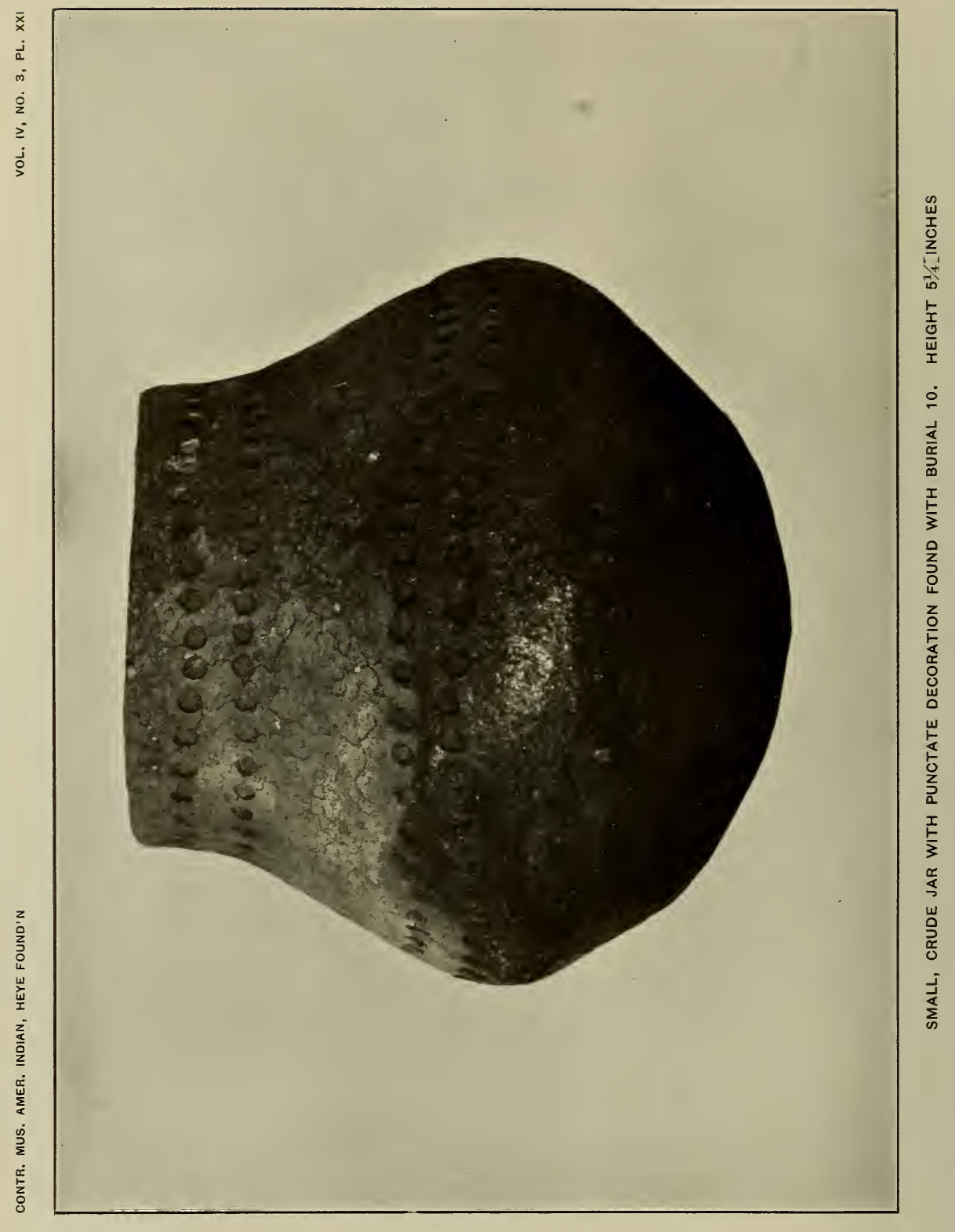


ashes; and under and about another stone, about the middle of the deposit, were several fragments of a smoke-blackened cooking-pot of incised ware, with a quantity of charcoal under and about them. South of and adjoining the southernmost stone of the deposit was a well-defined flooring of red-burned earth, its upper surface smokeblackened, covering about one foot square. Indeed, the entire ground covered by the stones had been burned before the stones were placed, as fragments of charcoal and of red-burned earth were mingled with the dark earth beneath the stones. Some of the stones had been fractured as if by heat, and two of them were much crumbled from the same cause. Removal of the stones exposed slight traces of a human burial, including fragments of the crowns of two teeth (Burial 9).

Another deposit of stones, generally similar to the last two described, but not associated with even a trace of skeletal remains, was uncovered in the northeastern part of the mound, $14 \mathrm{ft} .6$ in. below the surface. This deposit consisted almost exclusively of slightly water-worn or weathered stones, among which was some charcoal. There was nothing to indicate the object of the deposit. ${ }^{1}$

A deposit of stones $\mathrm{I} 3 \mathrm{ft}$. beneath the surface of the eastern section of the mound was similar to the last except that the stones were larger. The largest and uppermost stone was a bowlder that had been fashioned into a mortar; under it was a layer of yellowclay 8 in. in thickness, on a base of black earth 4 in. thick, both strata increasing in width toward the southeast. Twenty inches south of the bowlder-mortar and 18 in. below it was a heavy flat stone, $22 \times 14 \times 4 \frac{1}{2}$ in., in a slanting position. East of the stone last mentioned was a heavy deposit of large pieces of charcoal, while surrounding the stones and scattered through the dark layer beneath the clay were animal bones, some of which were calcined or smoke-blackened, mixed with which were potsherds and an arrowpoint. From his observation at this point, Mr Pepper concluded that house refuse had been thrown here at a time when it

${ }^{1}$ Merely for convenience of record this stone deposit was tentatively noted in the field as Grave II. 
was the slope of the mound. It was noted that the strata of material composing the mound here trended southward.

A stone deposit was found in the southwestern side of the mound, at a depth of ro $\mathrm{ft}$. This consisted of a bowlder of irregular form, I $31 / 2 \times 61 / 2 \times 5$ in., and, 22 in. southwest of it, a fragment of a flat stone, II $\times 81 / 2$ in., with broken edges. Just west of the bowlder, $3 \frac{1}{2}$ in., commenced a formless mass of animal bone measuring $9 \times 4 \frac{1}{2}$ in., by $4 \frac{1}{2}$ in. thick, but irregular in shape and with a hard coating such as has been already noted in connection with other decayed bone at Nacoochee. Fifteen inches southwest of this mass was another, smaller but of similar composition. Small pieces of bone mixed with charcoal were scattered through the deposit.

Five inches north of the northern end of the stone stratum near the base, referred to on page 34, and two feet above it, were four stones, three water-worn, the other irregular in shape, all, laid horizontally. These were deposited outside the dark "smallmound" area described, but just above it. Nothing was found with them, and there seemed to have been no connection between these stones and the stone stratum at the base. In the southeastern section of the mound, I6 ft. in depth, was a large grooved stone, standing on end, with only charcoal in association.

\section{BONE DEPOSITS}

A mass of bone that appeared as if it had been burned, together with the usual charcoal, was found at a depth of $16 \mathrm{ft}$. in the southeastern part. The bone had the appearance of having been partly decomposed, and, possibly with a mixture of shell, had formed a coating on the surrounding soil similar to that noted in connection with the pockets found with Burial 53. No artifacts were found in this deposit.

At a depth of $\mathrm{I} 7 \mathrm{ft}$., in the eastęrn portion, a mass of animal bones was found in a much decayed condition, but identifiable as those of a canine, probably a fox. The bones were disposed in such manner as to indicate that the animal had been buried with some degree of attention. Nothing was found with them. 


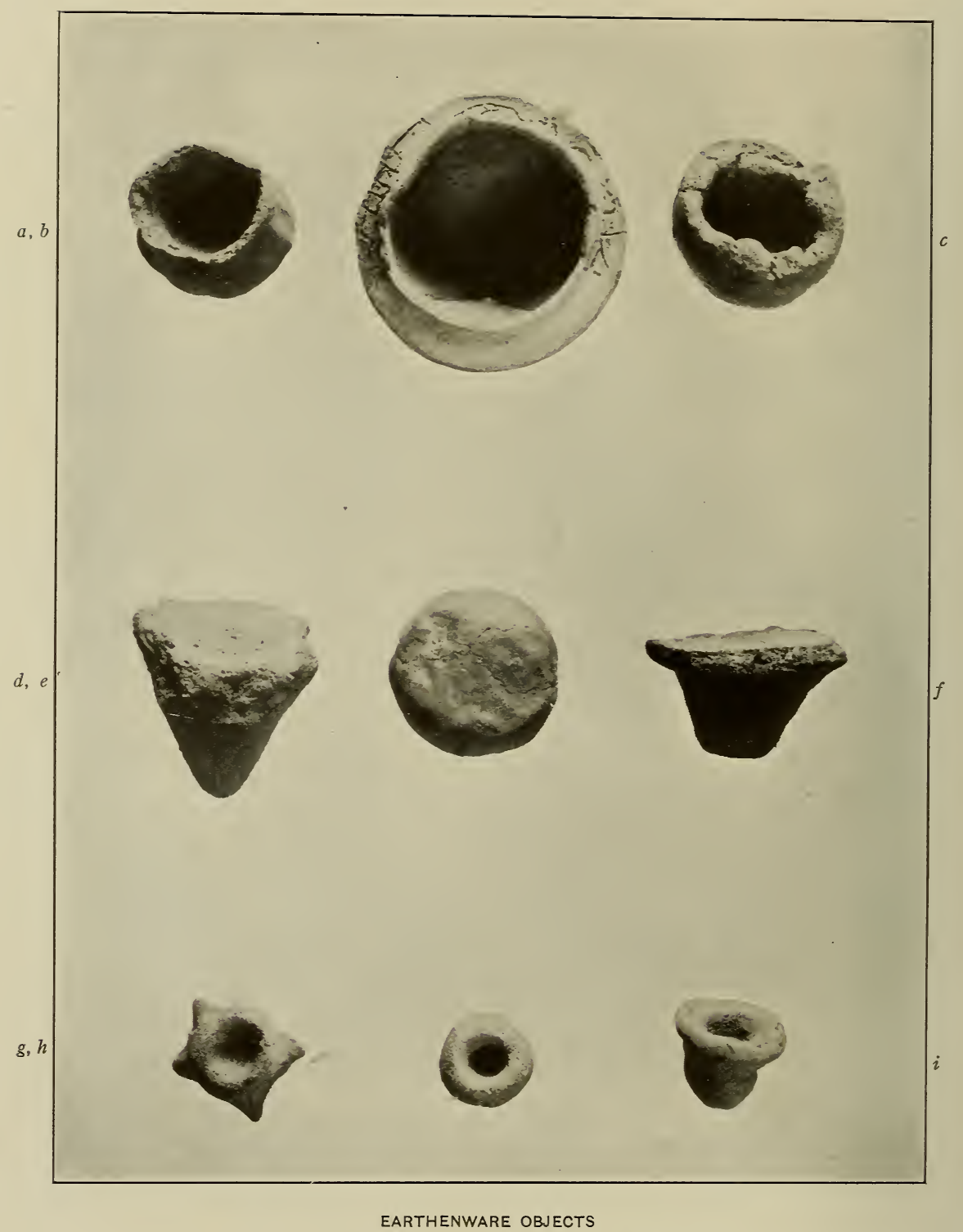

$a-c, g-i$, TOY VESSELS. $d, f$, KNOB HANDLES FROM UTENSILS. $e$, DISCOID 
A deposit of burned bones was found 19 feet in depth in the northeastern section, extending N.E.-S.W., and covering a space $8 \times 17$ in., by 2 to $2 \frac{1}{2}$ in. in thickness. The bones had been calcined to such an extent as to have become broken into small pieces. On the middle of this deposit, separated from it by a thin layer of earth, was a round, flat stone, $6 \frac{1}{2}$ in. in diameter and $x \frac{1}{4}$ in. thick, showing evidence of slight use.

In the southeastern part of the mound, $9 \mathrm{ft}$. deep, was another deposit of animal bones, mostly of deer, that had been buried as a mass. Charcoal was scattered through the immediately adjacent soil.

Reference to stray bones found throughout the mound will be made in describing the bone artifacts.

\section{HUMAN BURIALS}

The features of the mound and its more or less unusual contents having been referred to, we will consider the burials of a more commonplace character. In all, seventy-five burials were unearthed, none of which was in a state of preservation to enable measurement, and all of them indeed were so greatly decayed as to be entirely beyond recovery.

Burial I.-(Depth 2 ft. 9 in.) A small child, directed E.-W., head to E., extended on back. Entirely decayed excepting a few teeth, a clavicle, a fragment of the lower jaw, and parts of a few ribs. The bones that had retained their form were protected by what had evidently been a breastplate consisting of large shell beads. A string of smaller shell beads, by which the breastplate had been suspended, was found under the jaw; among these were two shell hair ornaments. About one foot southwest of and six inches above where the skull had been, were four discoidal stones, irregularly placed. Traces of charcoal were above and beneath the burial.

Burial 2.-(Depth 2 ft. 9 in.) Adult directed N.N.E.-S.S.w., head to s., lying on right side, knees flexed upward, hands in front of face. Bones generally soft, but some of them in fair condition. Under the jaw was a catlinite platform pipe (pl. XLIX, a) with the 
stem toward the feet, with Marginella shells in the pipe-bowl but which seemed to have been in a string that had been attached to the hole in the lower part of the pipe. Around the neck was a string of blue glass beads, which likewise seemed to have been attached to the pipe. On and under the scapulæ and pelvis were Marginella and other shell beads that evidently had been fastened to a shirt and leggings. Under the lower leg were two polishing stones and a small piece of ground rock-crystal. Between the knees and the vertebræ were two small stone discoids, one of them, green in color, found hollow-side down, being nearer the spine. Above the remains were traces of charcoal and deer bone, and a few potsherds. Under the skull and extending to the scapulæ was a thin layer of ashes, and under the pelvis, mixed with the shells above referred to, was a small, worked, triangular stone. By the feet was a small stone implement ( $\mathrm{pl} . \mathrm{Lr}, i)$ that probably had been used in modeling pottery. (Pl. XIr, a.)

Burial 3.-(Depth $2 \mathrm{ft} .4$ in.) Adult, directed S.E.-x.T., head to S.E., lying on face with legs flexed backward so that the feet touched the pelvis. On each upper arm was a broken copper armband that had been lined with bark. Under the right jaw was a mass of red paint, and beneath the chest was a breast-ornament consisting of 410 Marginella shell and glass beads. A small, long bird-bone (?) and two bone aw-ls were at the upper part of the vertebræ. Extending from under the left arm-band to the feet was an irregular line of bird-bones, and under the left elbow was a small piece of micaceous stone. Beneath the entire body was a layer of red-burned earth resting on black ashes, evidently indicating that a fire had been kindled over the grave area before the interment was made. The bones of the skeleton were fairly well preserved, but the skull was crushed. (Pl. Xrv, b.)

Burial 4.-(Depth 2 ft. 9 in.) Adult, directed E.-W., head to E., lying on right side with legs flexed; bones badly decayed and skull crushed. At the back of the scapulæ was a stone pipe (pl. $\mathrm{XLIX}, e$ ), the bowl toward the feet, and beneath the pipe were four glass beads. A copper button lay at the base of the vertebræ, and another, together with two lead buttons, was above the pipe. There 



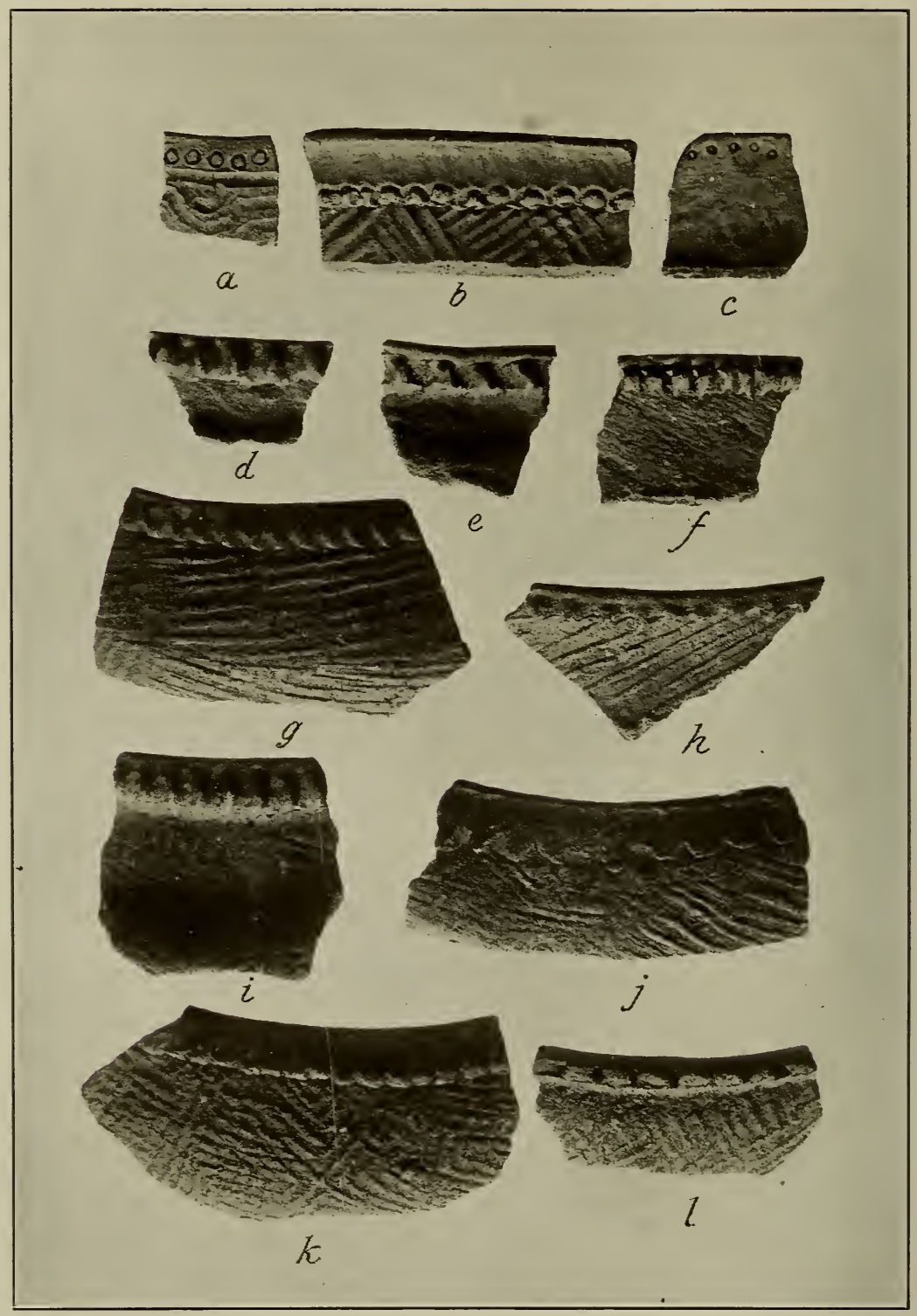

EXAMPLES OF RIMS OF VESSELS 



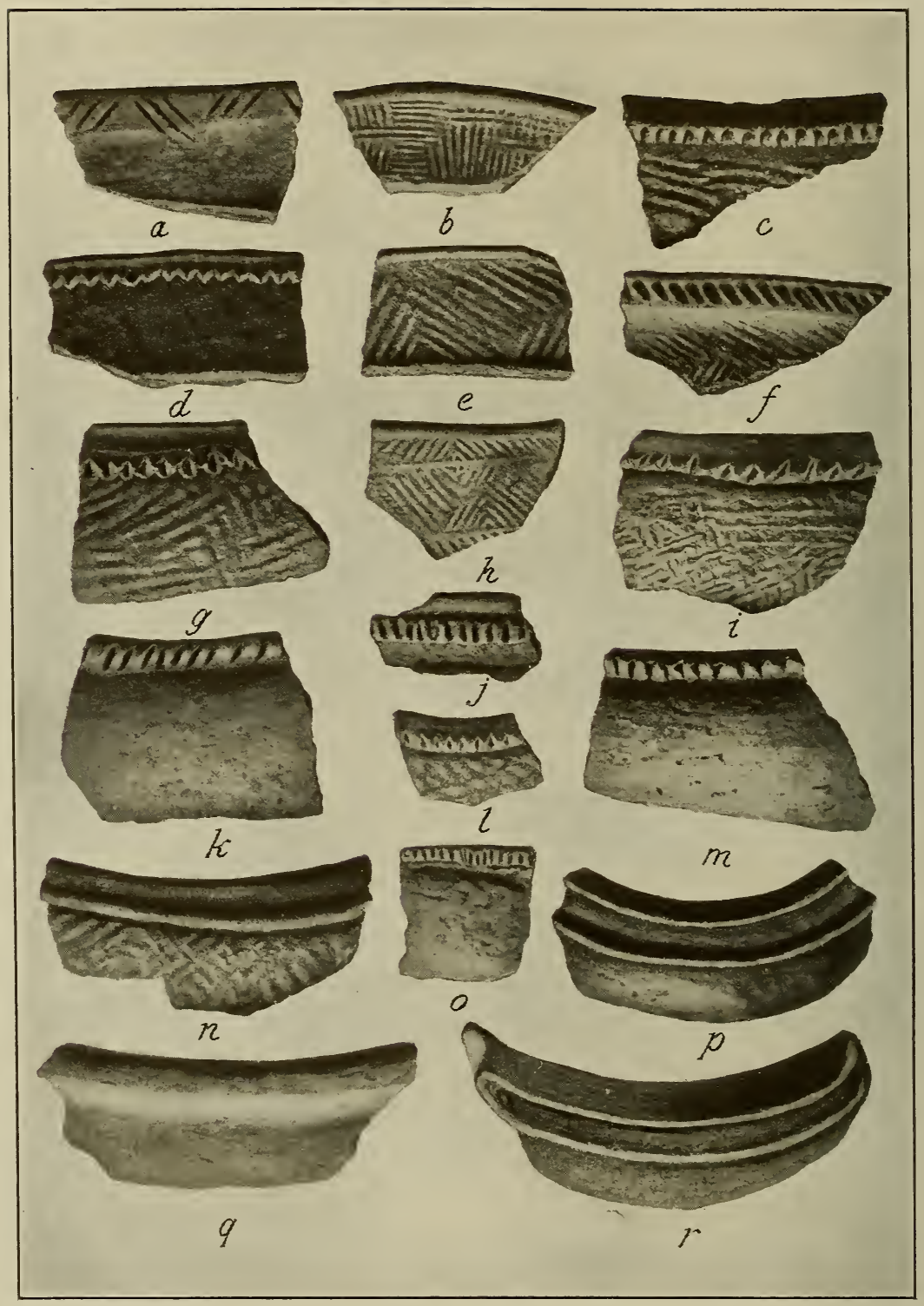

EXAMPLES OF RIMS OF VESSELS 
were also three lead buttons in front of the arms and three more near the feet. This skeleton also had been placed on a layer of redburned earth, 2 in. thick, beneath which was a stratum of ashes 8 in. in thickness, and another thin layer of red-burned earth. (Pl. $\mathrm{XV}, a_{\text {.) }}$

Burial 5.-(Depth 3 ft. 8 in.) Adult, directed N.-S., head to N., lying on left side with hands under chin; legs greatly flexed backward so that the feet were against the hips. The skull, and indeed the entire upper part of the skeleton, were greatly decayed, many of the bones having disappeared. Around the neck was a necklace of shell and glass beads, and on one of the knees was a small piece of graphite.

Burial 6.-This burial has already been described in connection with an adjacent stone deposit. See pages $35-36$.

Burial 7.-(Depth 4 ft. 5 in.) Adult, greatly decayed, only the teeth being well preserved. The head was directed approximately s., but not enough of the skeleton was traceable to determine whether the body had been flexed. In association with the teeth and the traces of the skull were $2 \mathrm{I}$ white shell beads, badly decomposed, varying in length from a quarter to half an inch. Slight traces of baked dark clay lay beneath the skull.

Burial 8.-(Depth $4 \mathrm{ft} .5$ in.) Adult, found $5 \mathrm{ft}$. north of Burial 7. Only traces of the skull and teeth were observable, the remainder having disappeared through decay, except for discoloration of the soil. The burial, however, had been made with the head directed southward and the legs had probably been flexed toward the E. There were no accompaniments.

Burial 9.-This burial has been described in connection with an accompanying stone deposit near the middle of the mound. See pages $36-37$.

Burial I0.-(Depth I ft. 5 in.) Faint traces of bones only, not sufficient to determine their character or the direction of burial. Accompanying these traces was an entire jar ( $\mathrm{pl}$. XxI), standing upright, and immediately back of it, $i$. e., northward, was a fire-pit, filled with red-burned earth and ash, mostly the former, measuring $\mathrm{I} 3$ in. in depth and $8 \mathrm{in}$. in greater diameter. The top of the firepit was I ft. 7 in. below the surface of the mound. 
Burial II.-See page 37 , note.

Burial I2.-(Depth $3 \mathrm{ft}$. Io in.) This adult skeleton consisted only of traces, which sufficiently outlined the burial, however, to show that it had been flexed westwardly. With the outer shells of some of the teeth was an earthenware pipe, crudely made and without ornamentation of any kind, and a similar pipe lay in close proximity to the spot that had been occupied by the skull. It is evident that this burial had been disturbed by the excavation made when the waterpipe previously referred to (p. 3) was laid. Covering the entire space beneath the skeleton was a layer of red-burned earth and charcoal. Slightly west of where the smoking-pipes were found was a deposit of seven flat rounded stones lying on their sides, beneath which was a pocket of red-burned earth and coarse charcoal.

Burial 13.-(Depth $6 \mathrm{ft}$.) Adult, direction N.E.-S.W., headed N.E., lying on right side, the right leg flexed at a right angle, the other more extended. The skeleton was in bad condition, none of the bones being firm enough to remove and most of them being represented by little more than soil discoloration. At the neck were a fine leaf-shaped blade of flint (pl. $\mathrm{LV}, a$ ), pointing toward the feet; I 5 shell beads of two varieties, in a compact group, not in line as if the remains of a necklace; a shell disc or gorget, in three pieces, perforated as if for suspension, on which rested the flint blade and the shell beads; and an awl-like implement of antler, resting on the blunter end of the blade, but which evidently had not served as a handle.

Burial I4.-(Depth $6 \mathrm{ft}$.) Adult, on right side, skull directed E., arms flexed upward. Only half of the skeleton remained, and that in very bad condition. On the left forearm were the disintegrated fragments of a conch, the columella remaining, and a fine slate knife, $81 / 4$ in. in length (pl. Lvi, $b$ ).

Burial 15.-(Depth about $6 \mathrm{ft}$.) This adult skeleton also was greatly decayed, the skull being flattened to a pasty mass, but it was directed eastward. At the neck were two small univalve shell beads, too far decomposed to enable preservation.

Burial I6.-(Depth $81 / 2 \mathrm{ft}$. beneath the slope and $18 \mathrm{ft}$. below the summit.) Adult, on right side, head toward E., legs flexed and 
. 


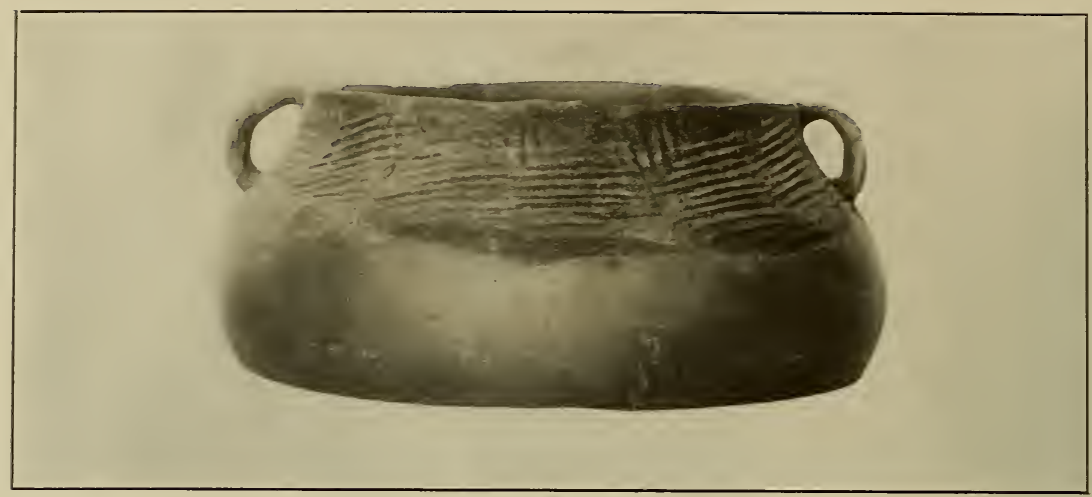

$a$
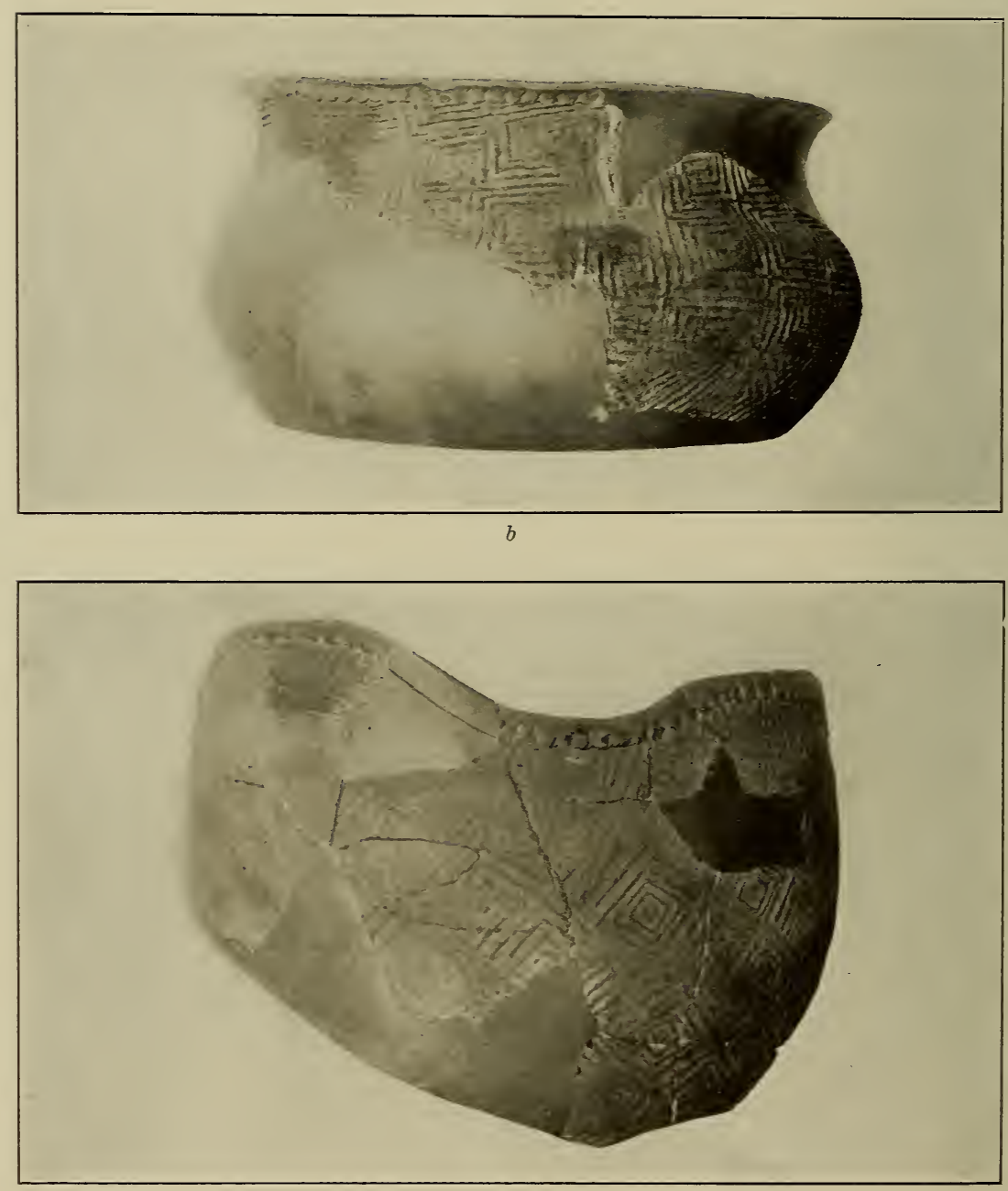

c

VESSELS WITH STAMPED STRAIGHT-LINE ORNAMENTATION 
arms drawn up at acute angles. The bones, which were little more than of the consistency of putty, lay on undisturbed brownish clay, the original base of the mound. There were no accompaniments.

Burial I7.-(Depth $9 \mathrm{ft}$. beneath the N.E. slope and $181 / 2 \mathrm{ft}$. below the summit.) Adult, head directed s.E., legs and arms flexed as in the case of Burial 16, bones of pasty consistency. Faint traces of charcoal were found in the earth about the skeleton, but there were no artifacts. The burial lay on the sand of the original valley surface, almost directly above Burial 16.

Burial I8.-(Depth $7 \frac{1}{2} \mathrm{ft}$. beneath the slope and $\mathrm{I} 9 \mathrm{ft} .21 / 2 \mathrm{in}$. below the summit.) Adult, the skeleton being represented by little more than streaks of color, while the bones best preserved were as soft as the sand in which they had been interred. The grave, which had been made in pure sand, was outlined by a discolored area measuring only $3 \mathrm{ft} .2$ in. by $2 \mathrm{ft}$., throughout which were particles of charcoal. The body evidently had been buried in the pit in a sitting posture. No artifacts whatever accompanied the remains.

Burial I9.-(Depth Io ft.) Skeleton of adult, badly decomposed, lying on right side, skull directed E., the hands before the face; the lower right leg drawn up almost against the upper, the left leg extended almost straight outward from the body; the vertebræ had disappeared, and there was almost no trace of ribs or of the smaller bones. The burial was made entirely in sand on a gravelly bed, the sand being so wet that it could be readily molded in the hand. There were no accompaniments.

Burial 20.-(Depth II ft.) Adult, badly decomposed, skull directed E., arms at sides; upper legs outward at right angles with the trunk, lower legs flexed. On the skull and around the body were patches of charred material resembling bark. The burial lay on sand, which had been discolored by contact. No accompaniments.

Burial 2I.-(Depth $3 \mathrm{ft}$. Io in.) A child, lying on the left side, head directed N.E.; lower legs flexed backward, so that the entire grave, which was well defined by the dark soil caused by the de- 
composition of the body, occupied a space of only $2 \mathrm{ft}$. 6 in. by I 5 in. The remains were badly decomposed. There were no accompaniments.

Burial 22.-(Depth $4 \mathrm{ft}$. Io in.) Child or adolescent, bones greatly decayed, only part being traceable. It lay on the left side, head directed N.E. Above the neck were four small shell beads, greatly disintegrated, and about the position of the left ear was a portion of what had the appearance of a shell ear-plug or possibly a hair-ornament, of limy consistency. On the chest lay a celt of slate, $7 \frac{1}{2}$ inches in length. This skeleton lay only $2 \mathrm{I}$ inches west of Burial $2 \mathrm{I}$.

Burial 23.-(Depth $3 \mathrm{ft}$. Io in.) The skull of this adult skeleton lay only $\mathrm{I} 7$ in. $\mathrm{N}$. from Burial $2 \mathrm{I}$, the measurement being made from center to center of the two skulls. Of the remainder of the skeleton, the leg-bones and part of the pelvis were found $3 \mathrm{ft}$. west of the skull, evidently having been removed in digging the grave for Burial 2 I, and then reinterred, since if the body had been buried so that the head was directed eastward, as seems to have been the case from the position of the skull, it must have overlapped Burial 2I. No artifacts were found with this skeleton.

Burial 24.-(Depth 51/2 ft.) Adult, head directed E.; legs sharply flexed backward, body on left side. The skull was greatly decomposed, no teeth were traceable, and little of the trunk remained. There were no accompaniments.

Burial 25.-(Depth 51/2 ft.) A child, skull only, in very bad condition, the teeth being represented only by their crowns. Possibly the remainder of this skeleton was dug away by a workman before its discovery. The body had been buried in an E.-W. direction, the skull pointing eastward and resting on its right side. Interment had been made in compact sandy clay, I4 in. above a sandy stratum. No mortuary objects were present.

Burial 26.-(Depth $7 \mathrm{ft}$.) The badly decomposed skull and only traces of the skeleton of an adult which lay on the left side, head directed eastwardly, with slight traces of shells about the neck.

Burial 27.- (Depth Io ft.) The skull and the leg-bones of this adult skeleton were the only parts remaining, and these were dis- 



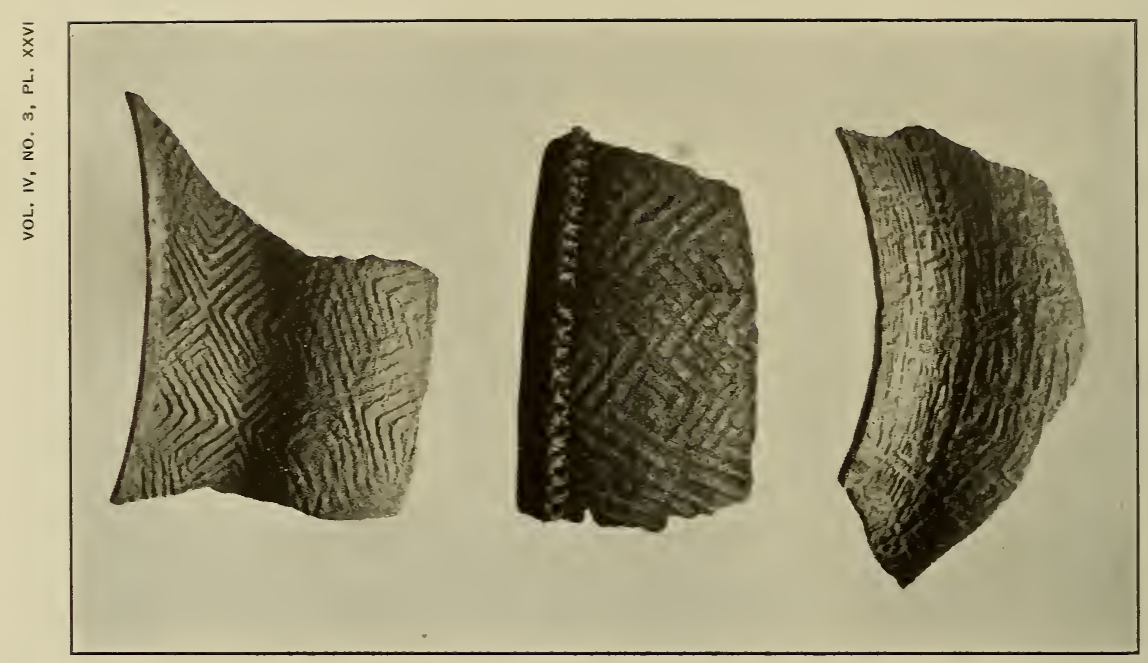

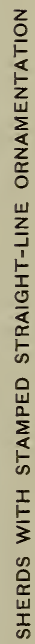

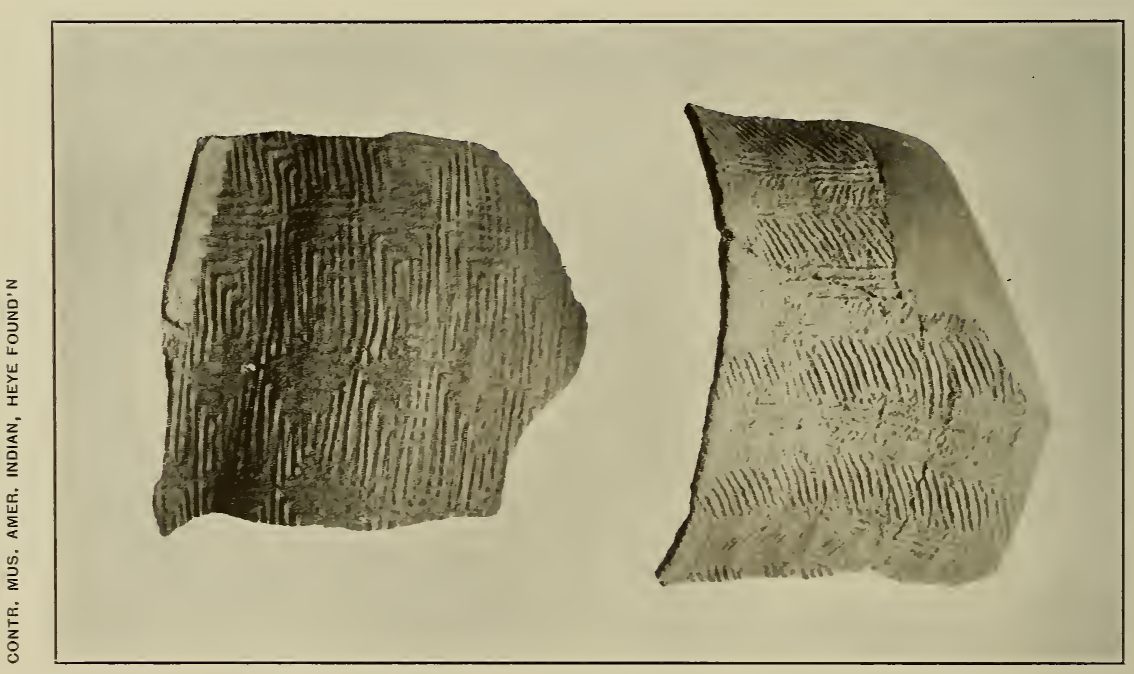





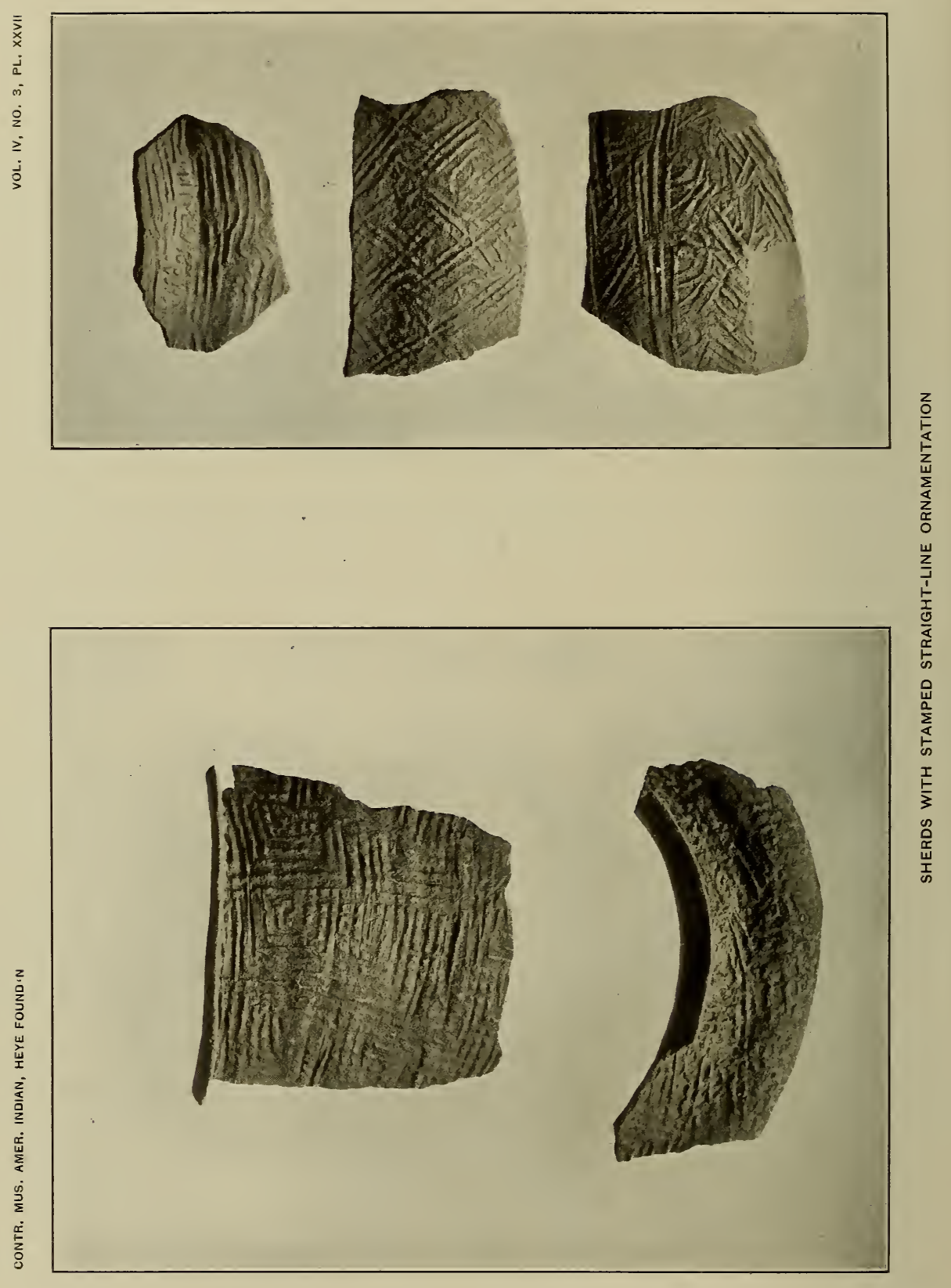


integrated from decay and the skull crushed. The body seemed to have been buried on its left side, as nearly as could be determined from the faint traces of the bones of the trunk. The skull pointed eastwardly; the legs were greatly flexed. There were no accompaniments.

Burial 28.-(Depth $5 \mathrm{ft}$.) This insignificant burial had no accompaniments. The skeleton lay on its right side, the skull, completely flattened, directed eastwardly. The bones of the trunk were merely traceable and the leg-bones were hardly distinguishable.

Burial 29.-(Depth $4 \mathrm{ft} .6$ in.) This skeleton was sufficiently preserved to show that the skull was directed in a southerly direction, but its condition was so poor that it was not possible to determine any flexion. There were no artifacts.

Burial 30.-(Depth $3 \mathrm{ft} .7$ in.) This adult had been buried with the head toward the northeast, but only the leg-bones, part of the vertebræ, and faint traces of other bones, probably arms, were visible, the skull being completely missing. A rude hammerstone was with the remains, but as many such were found throughout the mound, it probably had no direct association with the burial.

Burial 3 I.-(Depth $6 \mathrm{ft} .3 \mathrm{in}$.) The remains of this burial consisted of the skull and a clavicle of an adult. The skull lay on the left side, and had been directed eastwardly when the interment was made. There were no artifacts.

Burial 32.-(Depth Io ft.) Adult, lying on left side, skull directed E.N.E., the body so flexed that from the hips downward the bones trended N.w.-S.E. The skull lay 8 in. lower than the body, the hips and knees being elevated to that extent, except that the skull was greatly flattened by pressure and decay. There were no accompaniments. The earth in which interment had been made contained many small pieces of charcoal and a few small potsherds, and the burial was above the sand stratum in which other burials in the vicinity were unearthed. A thin stratum of yellow clay, not exceeding five inches in thickness and extending over a length of seven feet, lay above the skeleton. This clay had been deposited purposely, as it occurred above the mound base and had been dug through in making the grave. 
Burial 33.-(Depth 91/2 ft.) Adult, lying on left side, headed x.E., legs strongly flexed backward. A shell bead and a shell pendant or other ornament probably made from the columella of a conch, lay below the former position of the right ear. The skull was entirely flattened.

Burial 34.-This burial has already been described in connection with a stone grave. See page I9.

Burial 35.-(Depth Io ft. 6 in.) Adolescent, head directed s.w., the first instance of such. The leg-bones were flexed rather sharply backward. There were no accompaniments.

Burial 36.-(Depth $5 \mathrm{ft}$.) Adult, lying on right side, head directed x.E., legs flexed at an acute angle. This skeleton, which was greatly decayed, had no artifacts in association.

Burial 37.-(Depth I I ft. 6 in.) Adolescent, lying on its right side but directed eastward, knees drawn closely to front of body. So greatly flexed was this badly decomposed skeleton that the length as it lay was only $2 \mathrm{ft}$. Io in. There were no accompaniments. This burial was directly on the sandy base of the mound, a foot lower and partly under Burial 35 .

Burial 38.-(Depth ro ft.) Adult, greatly flexed, the head to the S.E. and the feet toward the x.w., the lower legs drawn backward against the pelvis. The axis of the grave was $20^{\circ}$ east of north. There were no accompaniments.

Burial 39.-This burial has been described in connection with a stone grave. See page I9.

Burial 40.-(Depth $8 \mathrm{ft}$.) Adult, directed E.-W., with head to E. The body (only the skull and a humerus remained) lay on its right side on sand at the base of the mound. No artifacts were found in association.

Burial 4I.-(Depth I4 ft.) Adult, directed x.E.-S.w., head toward N.E. The flexed body was on its right side, but the skull rested on the occiput. The underlying stratum was of mixed clay and sand. The legs and pelvic bones were in a better state of preservation than the skull, which was crushed and of the consistency of putty. Under the shoulder there was a layer of carbonized material, averaging half an inch in thickness, which included 


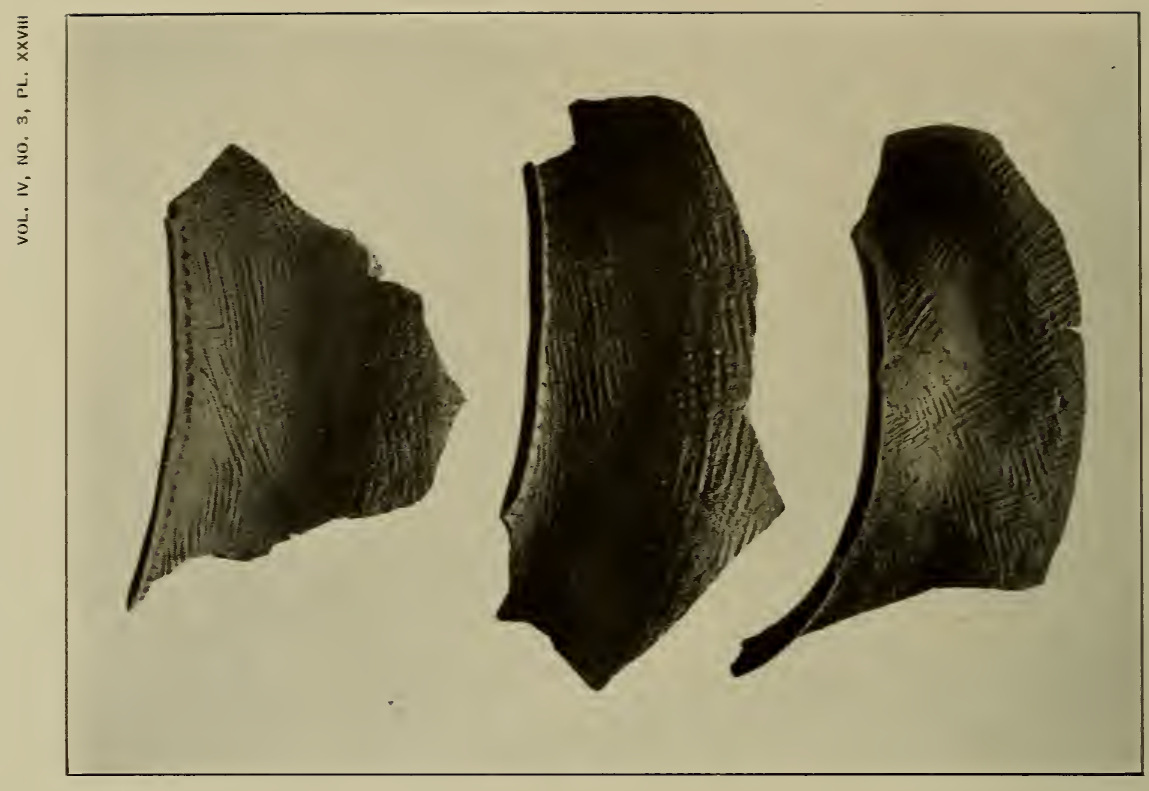

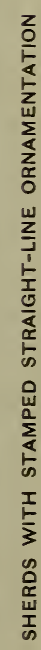


small sections of twigs. Near the pelvis was a fragment of a small earthenware vessel that seems to have had no immediate association with the interment.

Burial 42.-(Depth 14 ft. 6 in.) Adult, direction S.E.-N.w., the head directed S.E.; body flexed, on right side. Most of the bones, including the vertebræ, were definable. Nearly touching the top of the skull was a portion of the lower jaw of a deer, and near it a piece of quartz crystal and a bear-tooth.

Burial 43.-(Depth Io ft.) Adult, directed s.-s., the head toward the s. The body lay on its left side and was flexed. Only the crushed skull, a portion of the pelvis, and the femora retained sufficient form to enable identification, but there were traces of other bones. Beneath the skull a small piece of shell was found, and near it a round piece of graphite and a small piece of rock crystal.

Burial 44.-(Depth I4 ft.) Adult, directed S.E.-N.w., with head toward s.E., body extended on back, face upward. The lower parts of the femora had completely disappeared, and there was no trace of the bones of the lower legs and feet. Just above the pelvis were two pipes, one of earthenware, the other of stone, the former resting on the latter. Near the pipes were several small pieces of mica, and a small mica flake was found near the chin. Six inches below the pelvic arch, between the femora, was a flat unworked stone that probably had no immediate association with the remains.

Burial 45.-(Depth $9 \mathrm{ft}$.) Adolescent, extending S.E.-N.w., the head directed S.E., face upward, body flexed. The skull and the femora were the only bones remaining; the former extended at right angles to what had been the axis of the body. On the bottom of the grave was a number of very small pebbles, placed there evidently by design. Three feet southwest of the knees of the skeleton, and about 18 in. lower down, was a large stone celt, which evidently had not been deposited with this burial.

Burial 46.-This burial has been described in connection with the deposit of the copper celt, etc. See page 22.

Burial 47.-(Depth Io ft.) Adult, extending s.E.-N.w., flexed so that the head and face were directed s.w. The body was so bent 
that the knees almost touched the nasal bone. The bones were fairly well preserved, the ribs being firm enough to enable the separation of the earth from them-an unusual condition at Nacoochee. The body lay on its left side, the left humerus parallel with the body. This arm was flexed, the fingers resting on the skull. Two small pieces of shell were found near the neck. (Pl. xv, b.)

Burial 48.-(Depth $9 \mathrm{ft}$.) Adult, N.-S., head toward N.; body lying on left side; legs and arms greatly flexed, the elbows almost touching the knees and the hands resting under the chin. The skull was crushed and the other bones were too soft for removal, the vertebræ and the ribs being indicated only by light patches in the darkened soil. On the lower vertebræ was an earthenware pipe, broken into nine pieces (pl. XLVI, lower left-hand figure), probably at the time the grave was filled, as a stone large enough to have caused the damage was found nearby. (Pl. xvI, a.)

Burial 49.-(Depth $7 \mathrm{ft}$. Io in.) Adult, directed N.E.-S.w., head toward N.E., face down. The upper part of the body was extended and the arms rested at the sides. The skull, pelvis, and leg-bones were crushed and parts of them were decayed, and there was no trace of vertebræ or ribs. The femora were slightly angulated and the lower leg-bones bent upward. Nothing was found immediately with the burial, but two feet south of the well-defined grave area a fragmentary jar was unearthed, with the neck part upward, partly filled with black material solid enough for preservation. The extent of the disturbed earth was indeterminate, but it may have extended beyond the darkened soil immediately beneath the skeleton, hence the jar may have been designed to accompany this burial.

Burial 50.-(Depth $12 \mathrm{ft}$.) Adult, directed N.E.-S.W., head toward N.E.; body flexed, the knees being bent upward, touching the arm-bones. All the bones were greatly decayed and crushed. On the chest were the remains of a piece of matting (pl. xvI, b), beyond preservation. Near the body were a few very small pieces of shell. A number of animal bones mixed with charcoal were scattered through the earth surrounding the burial, which contained also a number of small chips of white and rose quartz. 



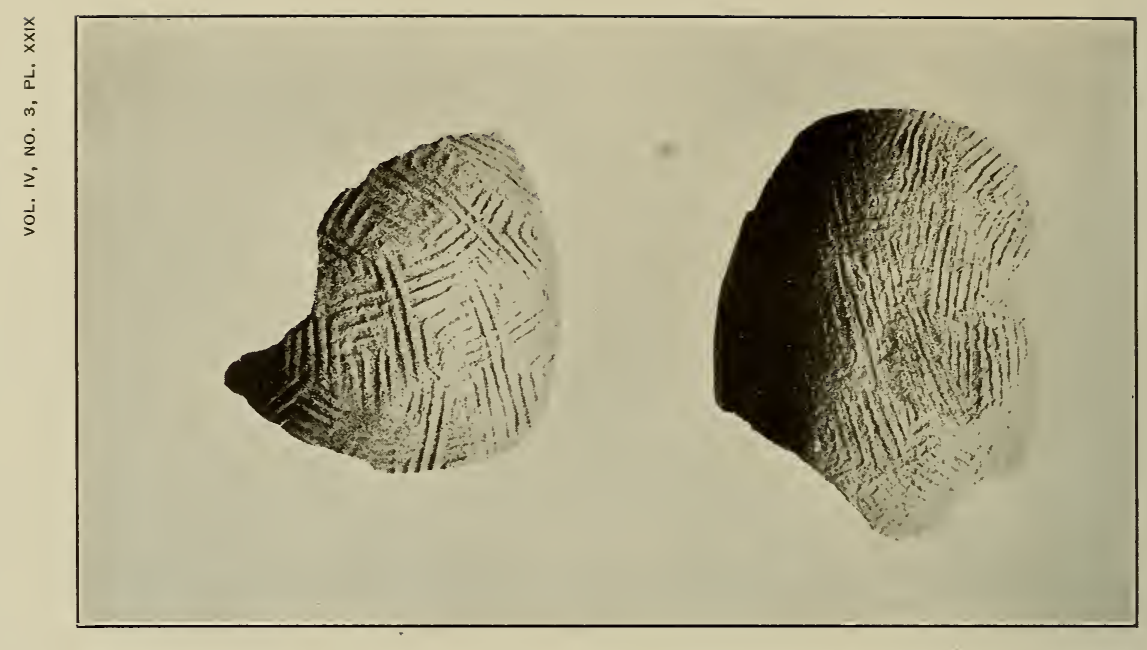

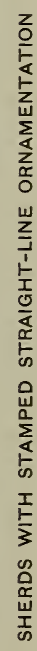

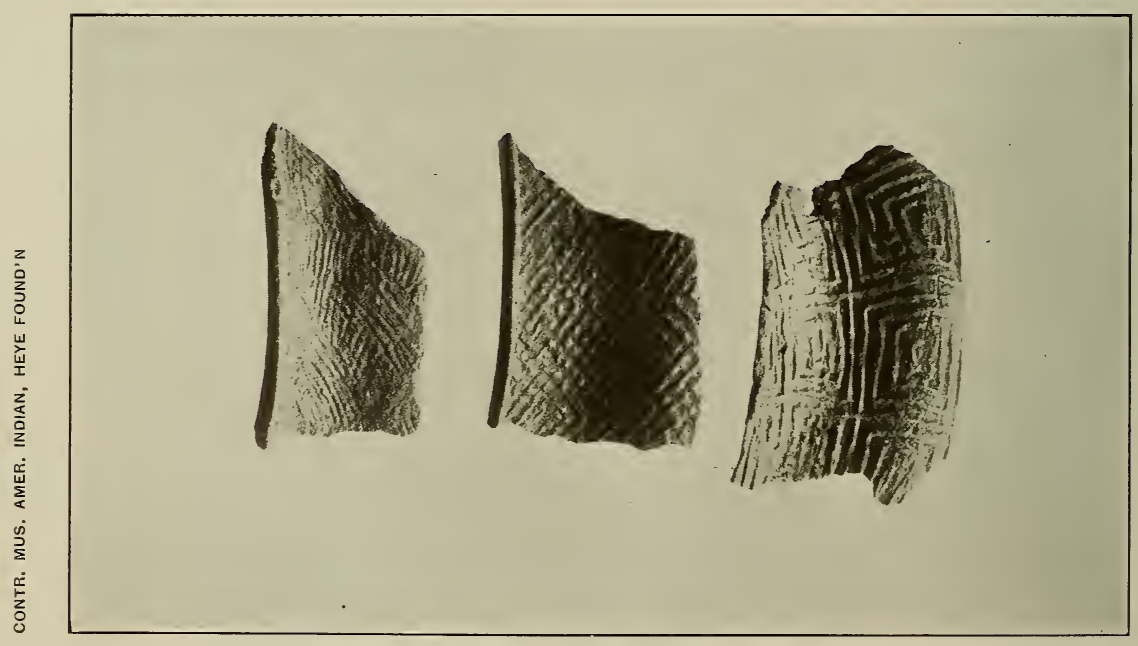





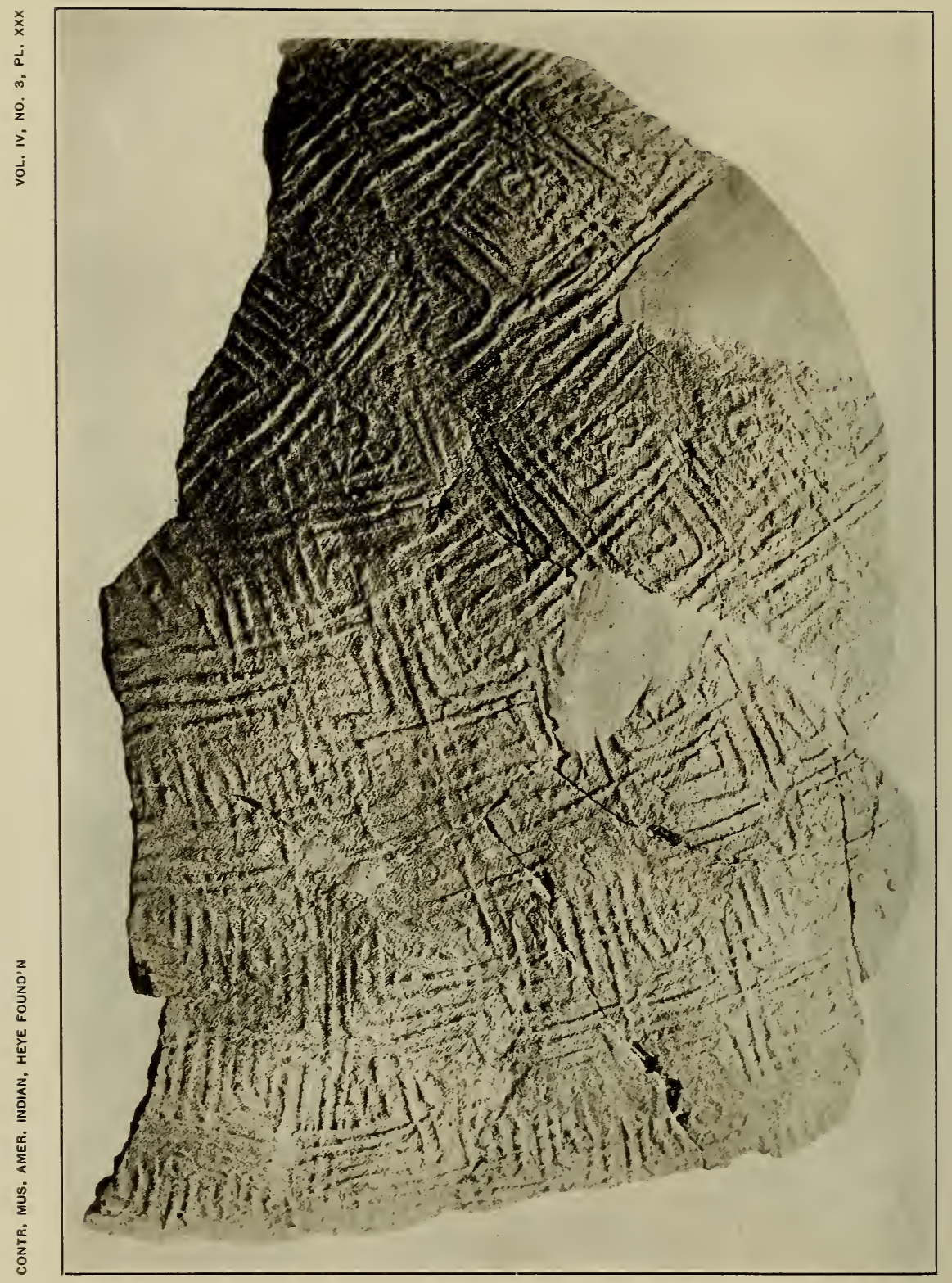

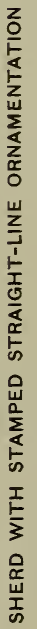


Burial 5I.-(Depth $16 \mathrm{ft} .6$ in.) Adult, directed s.w.-N.E., the skull s.w. The body had been flexed, but no other features of the burial were determinable owing to the advanced state of decay, only a portion of the skull, a femur, and a few other fragmentary bones being present. On the surfaces of the skull and the other bones there was a black incrustation of indeterminate character, and above and below the bones were a number of partially burned animal bones and several large pieces of charcoal. There were no artifacts.

Burial 52.-(Depth $18 \mathrm{ft}$. ) Adult, directed N.E.-S.w. This skeleton lay in moist earth, and the bones were so soft and lacking in distinctive coloring that the entire upper part was removed by a workman before the presence of the burial was noted. No artifacts were found.

Burial 53.-This burial in a stone grave has already been described. See page 25 .

Burials 54-56. -These burials have already been described in connection with the five pockets at the base of the eastern side of the mound. See pages $32-33$.

Burial 57.-(Depth I9 ft. 6 in.) This burial consisted only of a portion of the jaws of an adult which showed the lines of a few of the upper and lower teeth, together with faint traces of other bones. The grave had been lined with bark. As it was not possible to determine the direction of the burial, and as the limits of the grave were not well defined, it could not be learned whether the skeleton had extended under the disturbed area and Pocket 5 earlier described (p. 33), or had been directed eastwardly. There were no accompaniments.

Burial 58.-(Depth $12 \mathrm{ft}$.) Adult, directed N.E.-S.w., with head toward N.E. The body lay on its right side, the legs drawn up toward the trunk. A small discoidal stone was found above and within an inch of the pelvis.

Burial 59.-(Depth $18 \mathrm{ft}$.) Adult, directed N.E.-S.w., with the head toward the N.E. The body lay on its right side, the legs flexed. The skeleton was represented only by portions of the skull and the leg-bones, the other bones having disappeared through 
decay. The grave had been lined with bark. One foot above the skull and 18 in. northeast of it was a stone celt, and near it three small arrowpoints, similar in size, form, and material to those found with Burial 53, the skull of which was only a few feet from that of Burial 59.

Burial 60.-(Depth $6 \mathrm{ft} .5$ in.) Adult, buried probably in an E.-W. direction, with the head toward the E. All that remained of the skeleton were the femora and part of the pelvis. The legs had been flexed. About a foot from the burial, and extending southward from it about six feet, was a layer of large pieces of charcoal mixed with carbonized cane, suggesting a former shelter like that previously described as having been found near the summit of the mound. An inch above the bend of the knees was a large stone celt, lying on its side with the cutting edge toward the north, generally similar in size and shape to the celts found with Burials 53 and 59.

Burial 6I.-(Depth $6 \mathrm{ft} .9$ in.) Adult, directed S.E.-N.w., with the head toward the S.E. The skeleton was represented only by the skull and the femora, the skull being crushed. The position of the femora indicated that the legs had been flexed. The grave had been lined with bark, and an unusual quantity of charcoal was over and under the bones. A piece of disintegrated shell, about an inch in length, was found under the jaw.

Burial 62.-(Depth $7 \mathrm{ft}$. I in.) Adult, lying on its left side, directed S.E.-N.w., with the head toward the S.E., the legs flexed. The only recognizable portions were the crushed skull, the pelvis, and the femora. The bark lining of the grave of Burial 6 I extended under this skeleton also, and this, with the general discoloration, indicated that the two bodies had been buried at the same time. In the soil surrounding the two burials were a number of flattish pebbles, over each of which was about a double handful of clear sand. There were no artifacts.

Burial 63.-(Depth Io ft.) Adult, directed S.E.-N.w., head toward S.E., body resting on left side, legs flexed, face turned s.w. Only the skull, leg-bones, and one arm were present; the skull was crushed and all the bones were badly decomposed. Resting between 


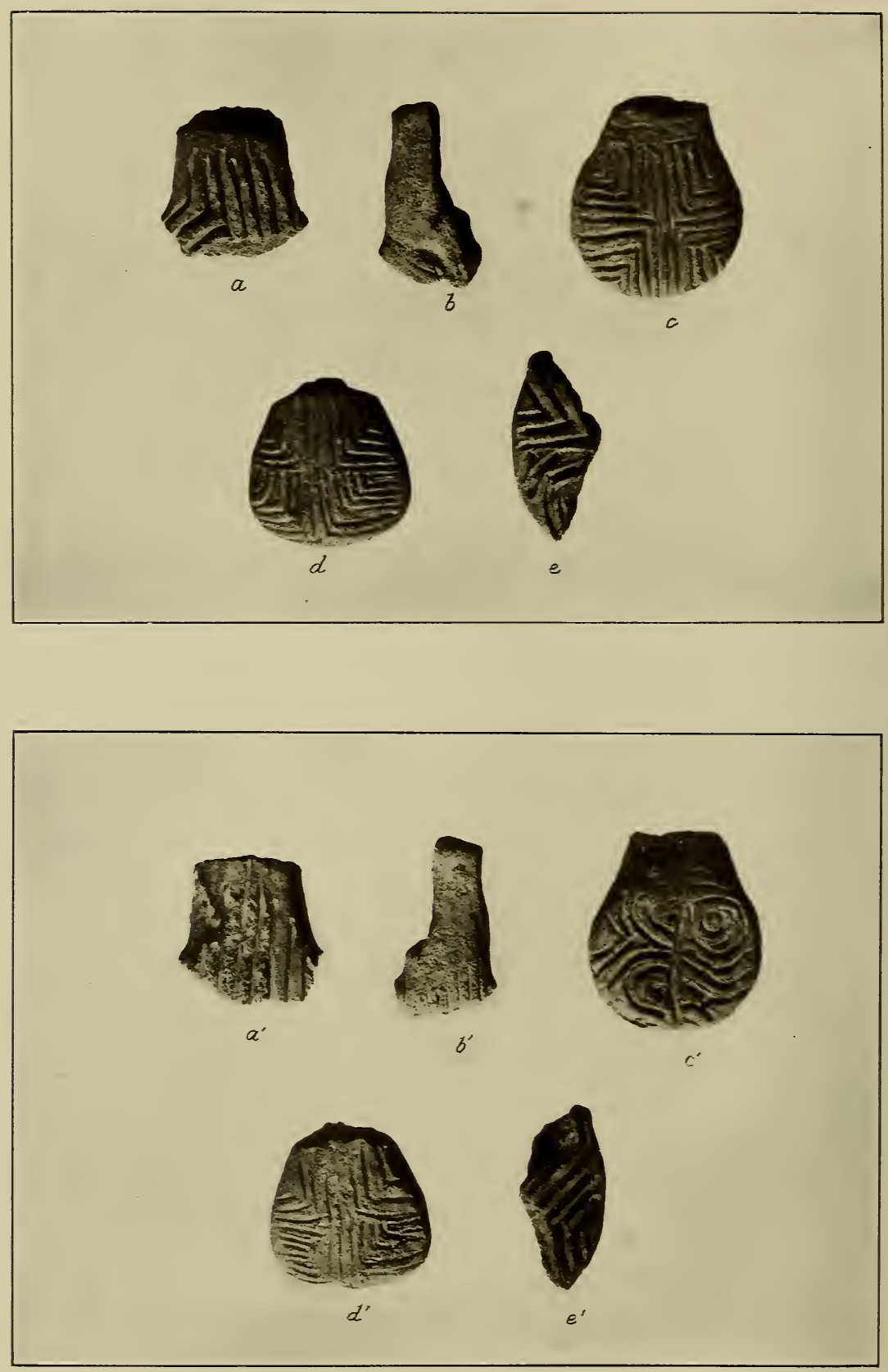

PARTS OF FIVE EARTHENWARE PADDLES USED IN ORNAMENTING POTTERY 
the femora and where the lower vertebræ would have been, was a large stone celt, with the blunt end toward the head, the implement parallel with the direction of the body. Six inches southwest of the feet was a large piece of charcoal, and a piece of rock crystal was found near the trunk.

Burial 64.-(Depth I6 ft. 6 in.) Probably a young adult, the only portions of the skeleton of which were the leg-bones, which had been flexed. There were no accompaniments.

Burial 65.-(Depth $8 \mathrm{ft}$. Io in.) Adult, directed s.E.-N.w., with the head toward the S.E. The body lay on the left side, the legs flexed. The bones were much larger than the average. No artifacts were found with the remains.

Burial 66.--(Depth $16 \mathrm{ft}$. Io in.) Adult, directed N.E.-S.w., with the head toward the N.E., body lying on right side and flexed. The bones were all greatly decayed and the skull was crushed. Nothing was found with the burial.

Burial 67.-(Depth $17 \mathrm{ft} .9$ in.) Adult, of which only the legbones and a portion of the pelvis were traceable. The orientation was indeterminate. No artifacts accompanied the burial.

Burial 68.-(Depth I8 ft.) A number of bone fragments only, none identifiable except those of the legs. The discoloration of the grave earth was well defined, and judging by its extent the skeleton had probably been that of an adult which had been flexed. It was not possible to determine the direction. No accompaniments.

Burial 69.-(Depth I8 ft.) The bones of this skeleton had disintegrated to such an extent that only a portion of the skull remained. The direction of the burial was not determined, and there were no artifacts.

Burial 70.-(Depth about $6 \mathrm{ft}$.) This skeleton was brought to light by the cave-in of the bank exposed by the great trench in the eastern section of the mound, following a heavy rain. Several teeth and a few fragments of bone were found, but careful search through the fallen material failed to reveal any other parts of the skeleton, and the exposed earth contained no grave discoloration. Directly above the point whence the bones came, there was a thin layer of charcoal about eight feet in length. With the bones and 
teeth were a fragmentary jar, a bone pin (fig. 6I), and the heads of two shell pins identical in form to those represented in fig. 59.

Burial 7I.-(Depth $8 \mathrm{ft}$.) A few teeth and fragments of bone were all that were left of the skeleton of this young person, and no artifacts were found with it.

Burial 72.-(Depth I4 ft.) Adolescent, directed N.E.-S.w., head toward N.E., back of skull turned to N.w.; body flexed in such manner that the vertebræ almost formed a semicircle. Most of the bones were in their relative positions, but a few had been scattered, perhaps by burrowing animals. Many of the bones were crushed and some were disintegrated, but the vertebræ were in better condition than any other found in the lower part of the mound. Near the pelvis, clam-shells in fragments were found, two of them in a fair state of preservation. In the earth just above the body were a pitted hammerstone, a stone disc, and two potsherds.

Burial 73.-(Depth $12 \mathrm{ft}$.) Adult, directed E.-W. with head toward the $\mathrm{E}$. and with body flexed as indicated by the curve of the vertebræ, which, however, was represented by little more than a line of color. The skull, the arm and leg-bones, and the pelvis were in better condition, but no other bones were in evidence. There were no artifacts.

Burial 74.-(Depth I6 ft.) The grave was well defined by the usual discoloration and was within a foot of the stone stratum previously described (see p. 34); but the skeleton had almost disappeared through decomposition. Parts of a Busycon shell were found with the bones.

Burial 75.-(Depth 12 ft. 6 in.) A child, directed S.W.-N.E., head toward S.w., an unusual but not unique direction in this mound. The body lay extended on its back, legs flexed, the face upward. The length of the skeleton from the skull to the ends of the leg-bones was only 22 inches; it was the only child's burial found in the lower reaches of the mound, a not surprising fact when it is considered how poorly preserved were the remains of adults. Nothing in the way of artifacts was found. 


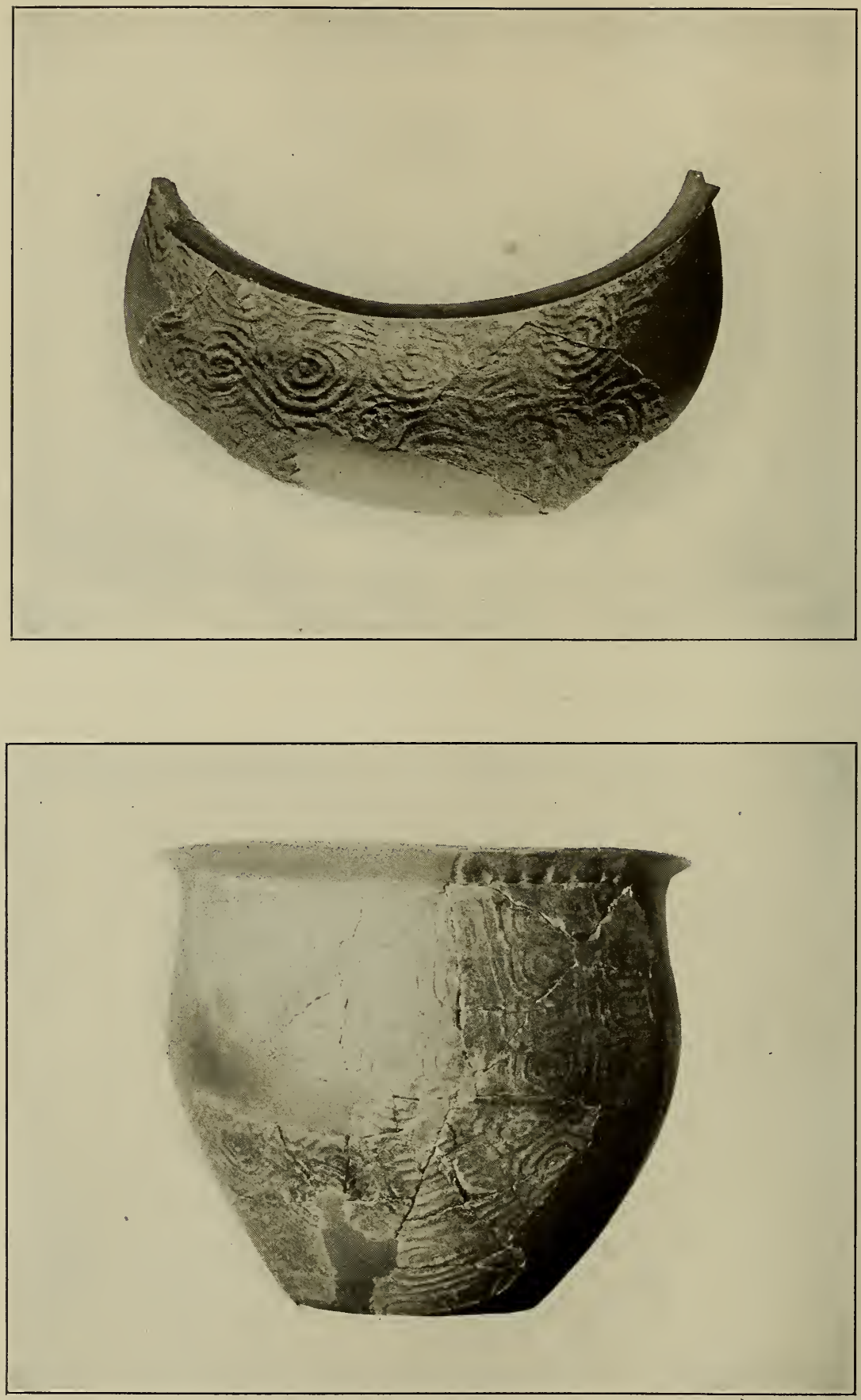

VESSELS STAMPED WITH CURVILINEAR PATTERNS 


\section{Summary of Observations on the Mortuary Remains}

It has been noted that all the skeletal remains uncovered at Nacoochee were in such a decayed condition that in no instance was it possible to preserve them for measurement; indeed in many cases the bones were so greatly decomposed that they could be traced only with difficulty. Considering the excessive precipitation in the Nacoochee valley, this condition is not surprising.

Of the 75 skeletons unearthed, 56 were of adults, 7 of adolescents, 4 of children, and 8 were unidentifiable as to age. Considering the condition of the skeletons of the adults, it was not to be expected that a greater number of burials of children would be encountered, especially as the presence of relatively few of the remains was revealed by accompanying artifacts.

With respect to orientation, it is observed that 48 of the dead were interred with the head directed eastwardly (E. I9, N.E. I9, S.E. Io), about 6 southwardly, 3 southwestwardly, 3 northwestwardly, and $\mathrm{I}$ in a sitting posture, while $\mathrm{I} 4$ were of indeterminate direction. ${ }^{1}$ In regard to age, we find that the direction of burial bears no special signification, as might have been expected, the summary of the data in this respect being as follows:

Adults: E. I4; N.E. I6; S.E. 9; S. 5; N. 3; S.W. I; sitting I; indeterminate 6.

Adolescents: E. 2; N.E. 2; S.E. I; S.W. I indeterminate I.

Children: E. 2 ; N.E. I; S.W. I.

As to the position in which the dead were deposited in the graves, we find flexion of the body and especially of the legs quite common at Nacoochee; indeed it was in exceptional instances that extended skeletons were met. Of the $5 \mathrm{I}$ burials whose positions in the graves were determinable, 47 were flexed in varying degrees, while only 4 were buried extended at full length - two adults, one adolescent, and a child. Of 42 skeletons, I9 lay on the right side, I6 on the left side, 4 on the back, 2 face down, and one was in a sitting position as above noted.

In the matter of mortuary artifacts, 27 of the 75 burials were

1 Adair (op. cit.. p. I82), writing of the Southern Indians without specifying the tribe in this case, refers to the burial of a chieftain in a tomb "with his face towards the east." 
accompanied with objects of more or less importance, II with objects of practically no significance (such as may have found their way into the graves through accident at the time of burial), while 37 of the burials had no accompaniments of any description. Nine of the graves showed evidence of having been lined with bark, and with four of the interments articles of European manufacture were found. These last burials were respectively at a depth of $33,28,33$, and 44 inches beneath the summit, indicating quite clearly that the mound had reached a height probably not far from its maximum during the historical period. It should not be forgotten that about two feet of the summit had been removed in recent time. With none of the deeper burials were objects of European provenience found.

In the latter part of the eighteenth century Adair wrote ${ }^{1}$ that "the Cherokee of late years by the reiterated persuasion of the traders, have entirely left off the custom of burying effects with the dead body; the nearest of blood inherits them." This statement, however, hardly applies to the inhabitants of Nacoochee, as there was no more indication that they had abandoned the custom of making funerary deposits during the later occupancy of the mound than in earlier times.

Further summarizing the data derived from the graves, we find their distribution as to depth beneath the surface of the mound as follows:

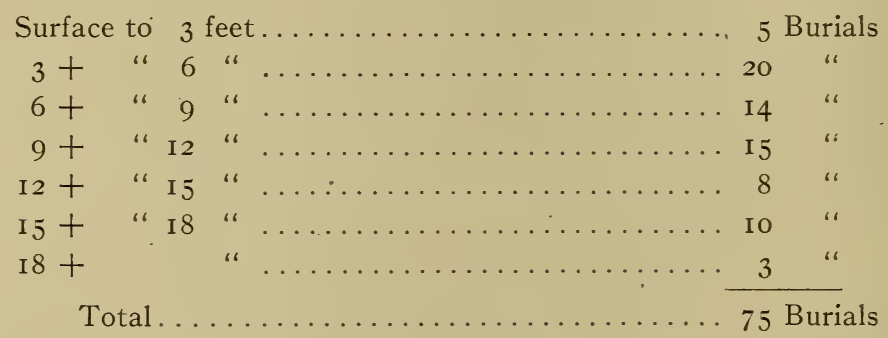

This distribution is presented merely as a matter of record, being admittedly of little value so far as the aggregate of burials in the mound is concerned, a relatively greater amount of digging being done in the upper than in the lower levels.

${ }^{1}$ James Adair, History of the American Indians, p. I 78, London, I 775. 


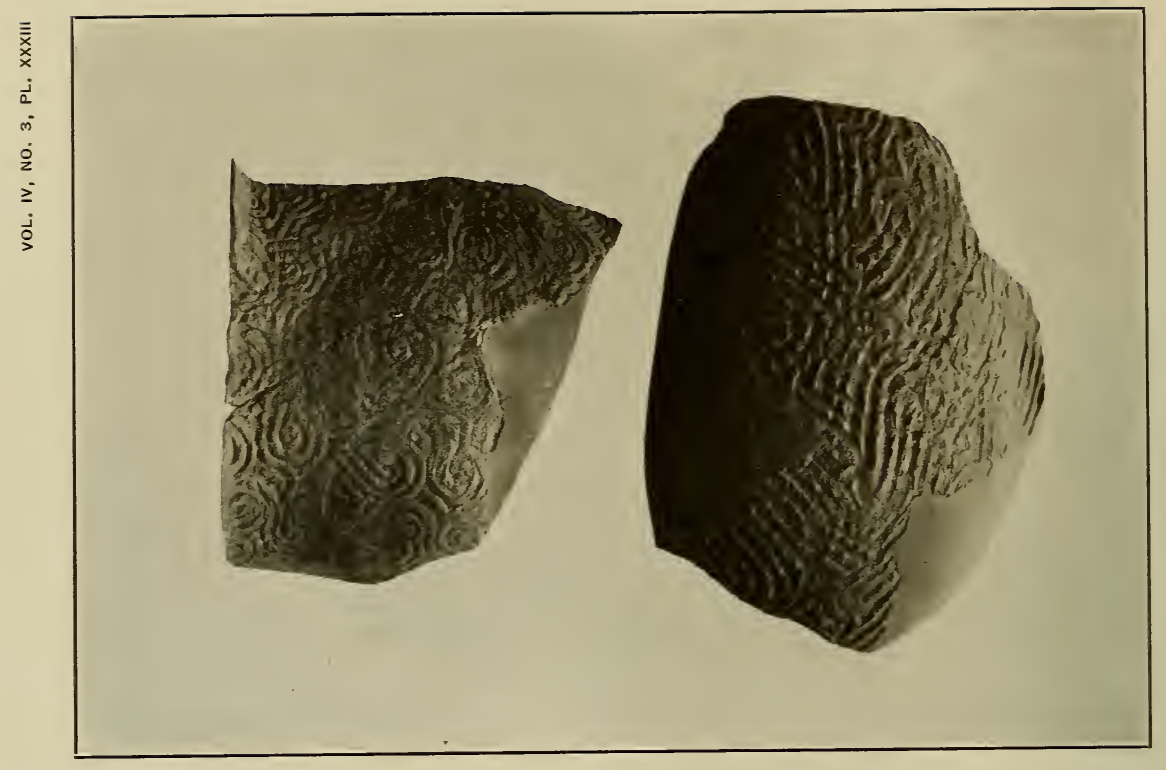

资 


\section{MATERIAL CULTURE}

\section{PotTery}

It has already been observed that there was a paucity of earthenware vessels found as funerary accompaniments at Nacoochee, and indeed entire vessels of any kind were quite rare. Fragments, however, large and small, were present in thousands, especially under the surface of the slope and at the base, where the receptacles, no doubt broken in use, had been cast during the occupancy of the mound. In a limited number of instances related sherds were found together, enabling more or less complete restoration, but in others only relatively small parts of the utensils were recoverable, yet sufficient to enable a study of their general character, former shape, and ornamentation.

\section{CHARACTER OF THE EARTHENWARE}

By far the greater number of the receptacles consisted of cooking-pots or water-jars of black or dark gray ware, which ranged in size from a few inches in diameter and height to one that measures 60 in. in maximum circumference and 15 in. high, while another is only slightly smaller; and indeed certain sherds indicate, from their size and curvature, that they are parts of vessels of even greater dimensions. Some large sherds of soft reddish ware were found, as well as other sherds of small bowls and jars, polished red inside and out, and without decoration. Almost invariably the ware is rather fragile, not only from long-repeated subjection to heat while in use for cooking, but owing also to the inferior quality of the paste, which was tempered with sand, often micaceous, or with sand and ground shell, or with shell alone, particles of which are plainly visible in a limited number of the vessels or their fragments. There is also reason to believe that pure mica was ground and mixed with the clay as a degraissant.

Timberlake, ${ }^{1}$ writing in $176 \mathrm{I}$, stated that the Cherokee "have two sorts of clay, red and white, with both of which they make excellent vessels, some of which will stand the greatest heat." Adair, ${ }^{2}$ writing about the same period, said:

${ }^{1}$ Henry Timberlake, Memoirs, p. 62, London, I765.

${ }^{2}$ Op. cit., pp. 424-425. 
"They make earthen pots of very different sizes, so as to contain from two to ten gallons; large pitchers to carry water; bowls, dishes, platters, basons, and a prodigious number of other vessels of such antiquated forms, as would be tedious to describe, and impossible to name. Their method of glazing them, is, they place them over a large fire of smoky pitch pine, which makes them smooth, black, and firm. Their lands abound with proper clay, for that use; and even with porcelain, as has been proved by experiment."

It may here be remarked that every variety of pottery found (with the exception of the painted effigy jar hitherto described, which evidently was intrusive), in both shape and ornamentation, was gathered at all levels of the mound, suggesting that the occupants manufactured all the types of earthenware throughout the occupancy of the site. The ware is of the typical Southern Appalachian form and style, in no particular respect different from that of other pottery made by the Cherokee in early times. ${ }^{1}$

In thickness the receptacles average from about three-sixteenths to a quarter of an inch, even the largest ones being comparatively thin-walled. The inside of the vessels was almost invariably smoothly finished, and in many cases it was given a black coating and polished, apparently to overcome the porosity to some extent and to facilitate cleaning. Probably it was this blacking and polishing of the inside of the pottery that Adair mentions.

Regarding the form of the vessels, the larger specimens, or rather those that admitted of restoration, are chiefly globular, with wide mouth, somewhat constricted neck, outcurving rim, and with the maximum diameter at the shoulder (pl. XVII, XvIII). In this type the bottom is generally rounded, but some sherds, evidently of jars, show almost flat bottoms. Other receptacles take the form of deep bowls, the body shaped like the jars from the shoulder to the base (pl. xIx). Others still had their greatest diameter at the somewhat flaring rim, the sides swelling considerably at the middle, or else to only a slight degree, then tapering gradually to the base. Unfortunately no complete specimen of this form of jar was obtainable, but the major part of each of two specimens is shown on plate

1 See Holmes, Aboriginal Pottery of Eastern United States, Fifteenth Annual Report of the Bureau of American Ethnology, Washington, I903. 


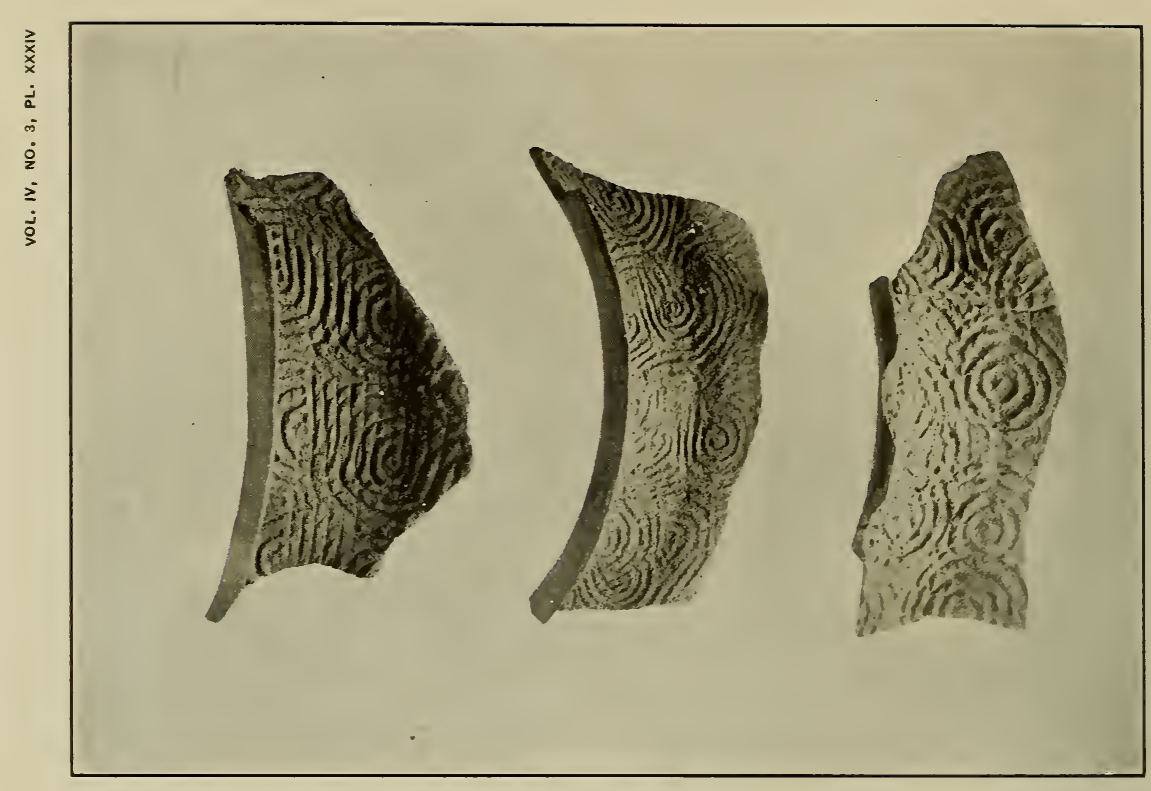

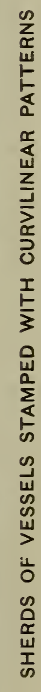

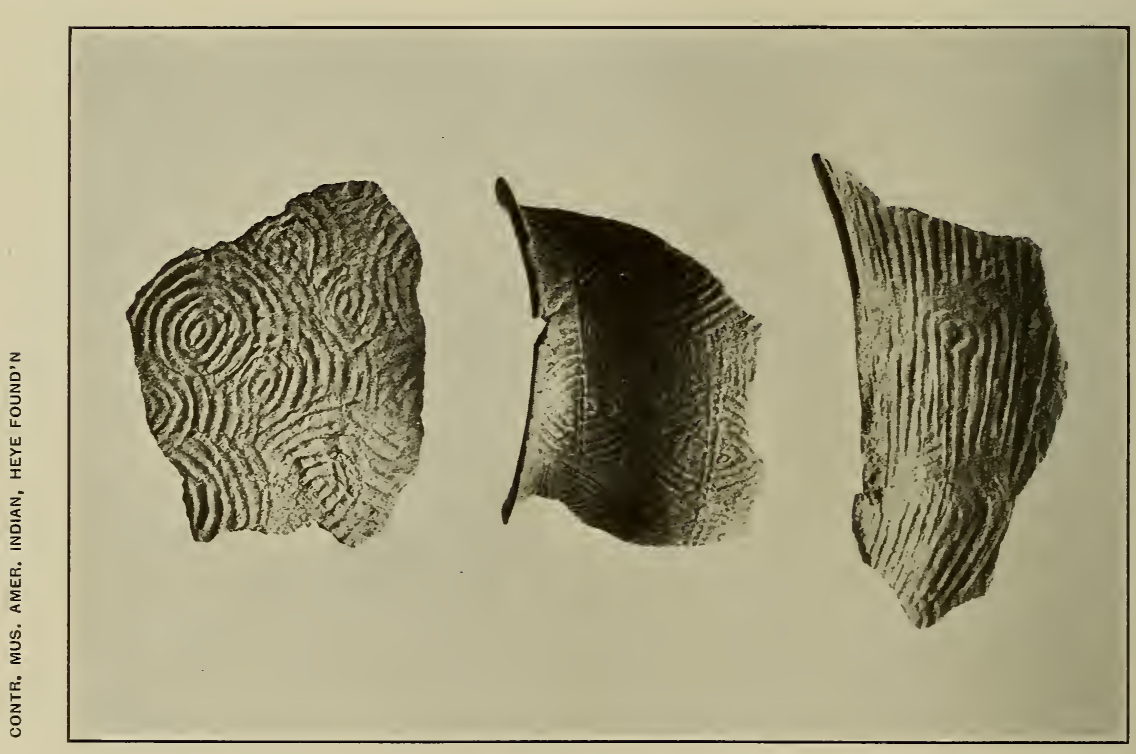


$\mathrm{xx}$. Some of the jars curved outward so slightly as to have been practically cylindrical.

The only jar found by us that may be regarded as complete (as it lacked only a small piece at the rim) was a mortuary vessel found with Burial io. This little vessel (pl. XxI) stands $5 \frac{1}{4}$ in., with a circumference of $\mathrm{I} 8$ in. at the middle; it is heavy in comparison with its size, and is of coarse ware and crude workmanship; but an attempt was made to relieve its homeliness by impressing in its surface two double bands with the two ends of a cane probably cut off at the nodes, or with two canes varying slightly in size.

In addition to this jar, however, there is another entire vessel from Nacoochee, a fine bowl that had been found by Captain Nichols and procured from Mrs Payne. This receptacle stands $7 \frac{1}{4}$ in., is $13 \frac{3}{8}$ in. in diameter at the rim, and measures 47 in. in circumference of body. While rather rough below the shoulder, the upper part of the bowl is ornamented with eight incised scrolls, connected at the top with straight bands which also form parts of simple geometric devices which fill the intervening panels. This bowl is illustrated in plate XIX, $b$.

Toy Vessels.-Five tiny vessels, evidently intended for toys and possibly all but the largest one made by children, are illustrated in plate XXII, $a-c, g-i)$. The one designated $c$ is thick and clumsy, but with the under-body polished as if from use. A large grain of sand is embedded in 'the inner. wall, showing with what carelessness the little bowl was formed. The largest vessel (b), a toy bowl, has been restored, but enough remained to enable determination of the entire form and character. It is smooth within, but almost unfinished and checked outside, and its shoulder-like rim is rudely incised by way of ornamentation. The smallest one shown $(g)$, only an inch and a quarter long, has almost the density of stone. Much of the body is taken up by four disporportionately large nodes, while the receptacle part is large enough only to receive the tip of the little finger.

Dippers. - Fragments of handles and bowls of small earthenware dippers are the only evidence that such utensils were in use at Nacoochee, no complete ones being found. 
Rims.-The rims of the vessels are of considerable variety, both in form and in ornamentation. The dentate border (shown in various examples in accompanying illustrations, especially in pl. XxIII, XxIv, and in fig. $5^{-I_{4}}$ ), which varies greatly in character and spacing, as well as in its relation to the lip of the ressel, was evidently the favorite device employed in embellishing the rims, judging by the large proportion of this kind found. In some

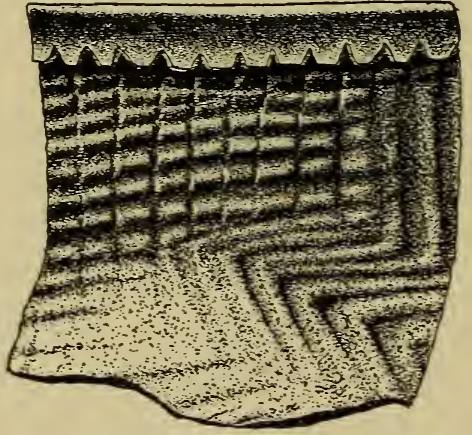

FIG. 5.-Dentate rim ornamentation.

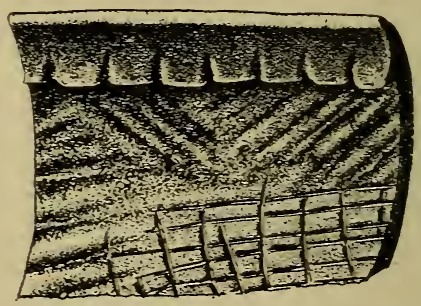

FIG. 6.-Dentate rim ornamentation.

examples the band is truly dentate or beaded, in others it consists of a series of rude nodes regularly or indifferently spaced, and in still others there is little more than a suggestion of ornamentation, the spaces being indicated by crude incisions, or the clay having been pressed into a semblance of finish by means of a blunt instrument, the end of a cane-stalk, or even with the finger-tip, which in some cases left its prints in the clay. Only in exceptional instances is the lip unaccompanied with an ornamental band or border of some kind, and in these the decoration of the sides with stamped or incised devices usually commences immediately beneath, as shown in the illustrations. In almost all cases the ornamental rim was applied as a separate strip of clay during the process of manufacture, and in these instances the body of the ressel had been ornamented with a stamped design and was almost if not quite dry when the rim portion was luted on. This process made the attachment of the rim quite insecure, as shown by a number of 


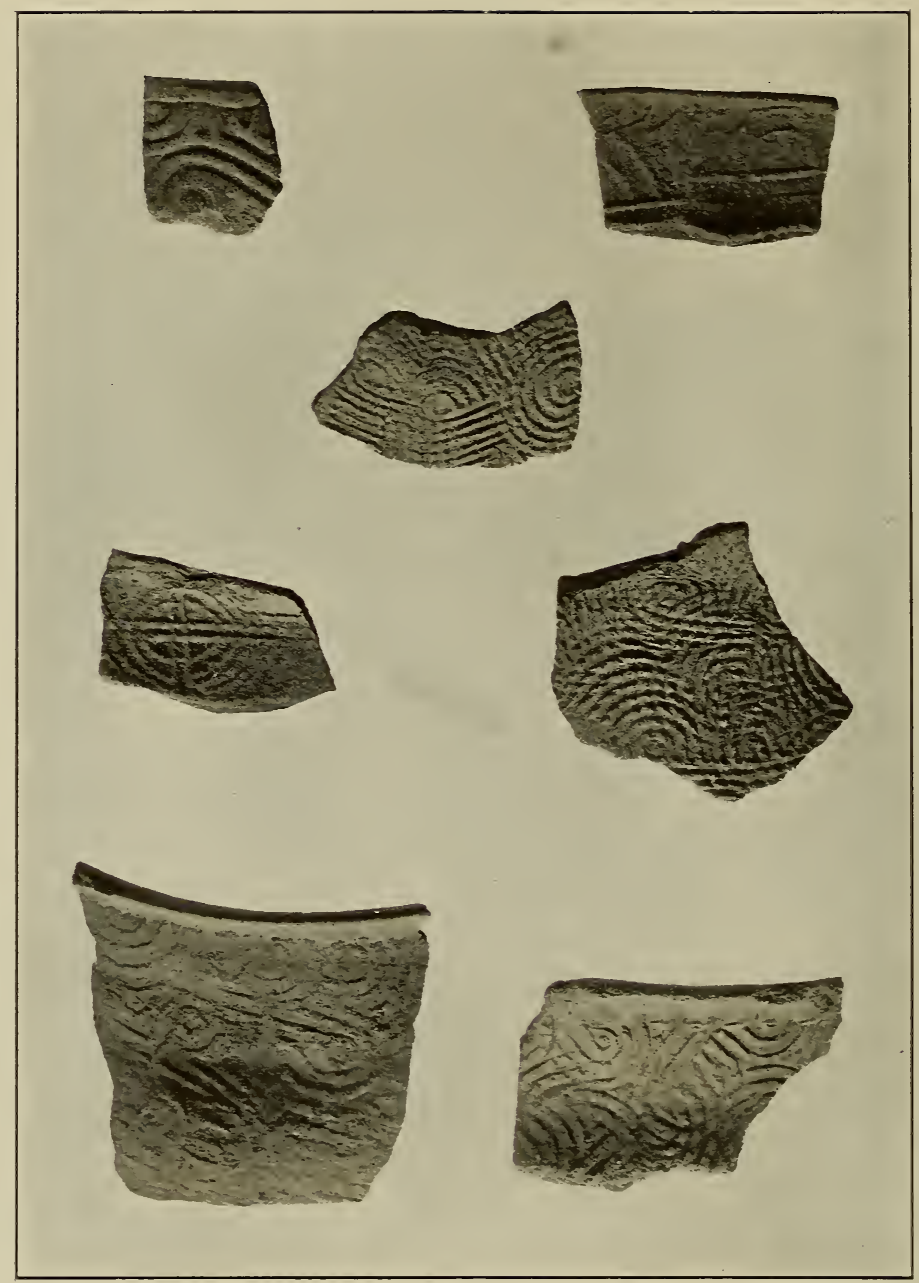

SHERDS OF VESSELS STAMPED WITH CURVILINEAR PATTERNS 

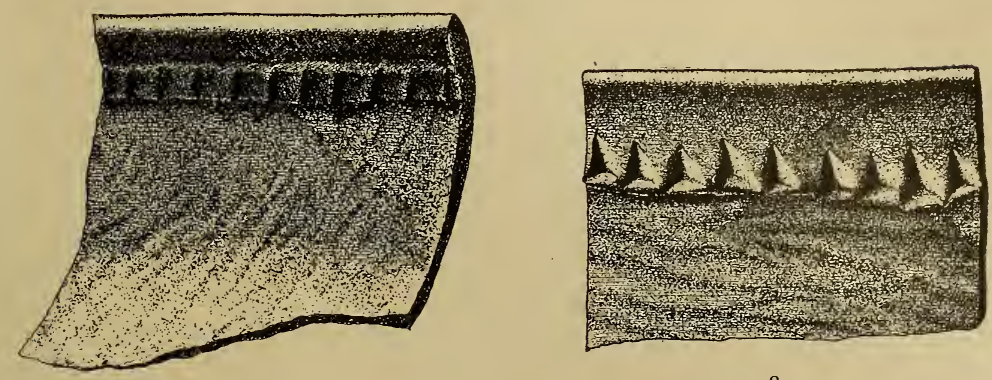

7

8

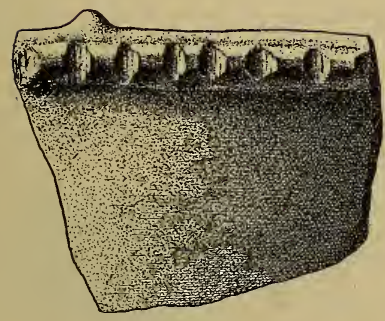

9

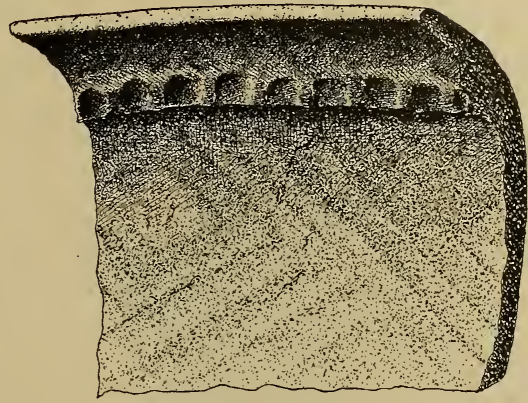

I0

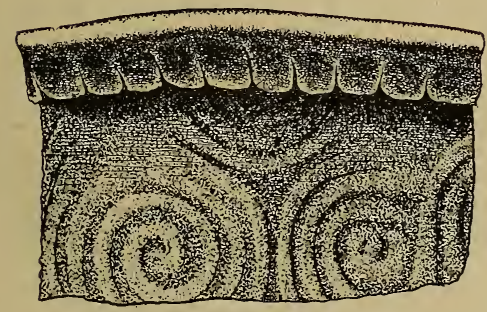

II

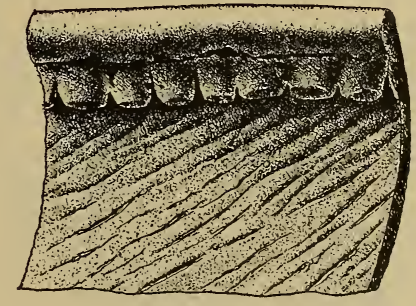

I 2
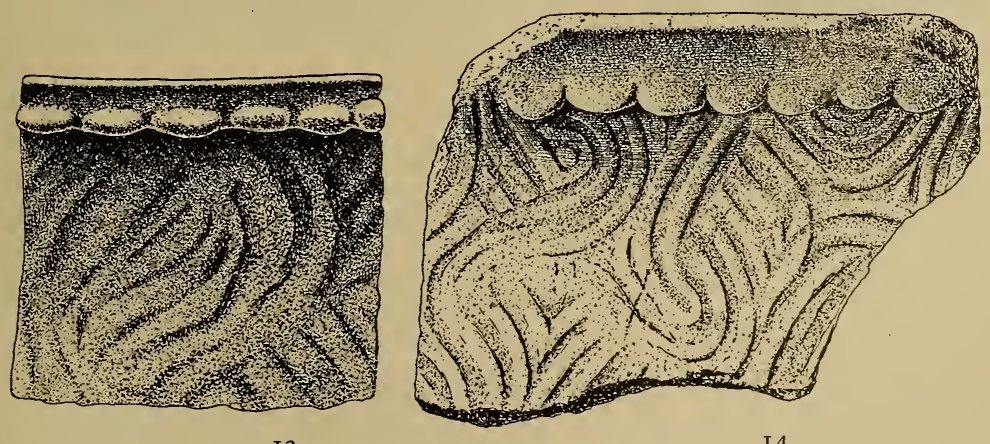

I3

I4

FIGS. 7-I4.-Examples of rim ornamentation. 
sherds from which all or a part of the ornamented rim has fallen away, exposing the stamped surface beneath. The reason for this seems obvious, for it was necessary to stamp a pattern on the walls of the vessel while the clay was still soft, which it probably would not have been had the potter waited until she first applied the sometimes tedious rim ornamentation.

In addition to the dentate or beaded form of rim embellishment, we find on vessels with stamped patterns on the body a number of other decorative devices at or near the lip, as shown in several of the illustrations. Noteworthy among them are the rims on which are present more or less grotesque human heads, some

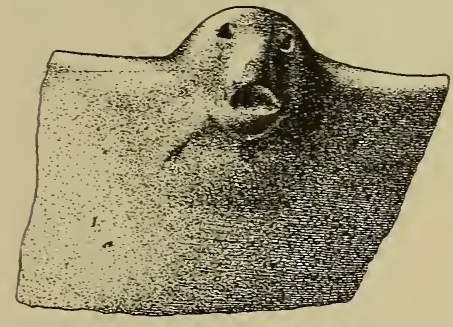

I5

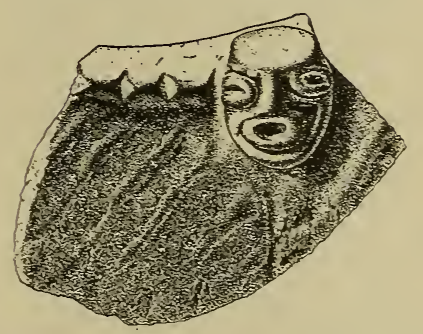

I7
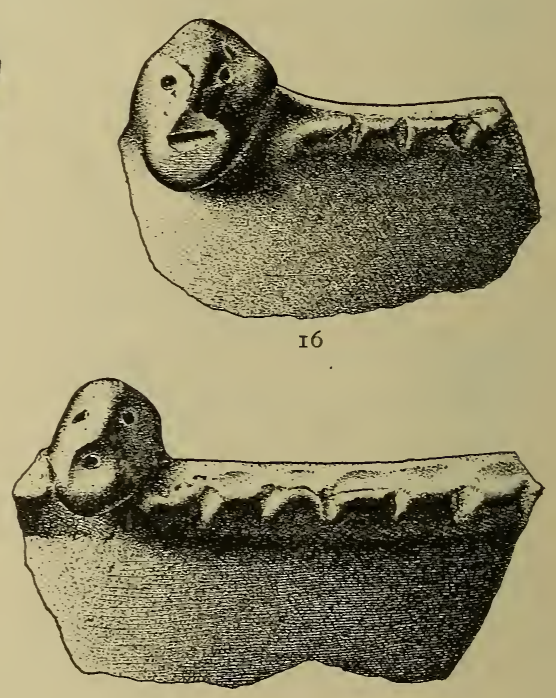

I 8

FIGs. I 5-I 8.-Grotesque heads on rims of vessels.

flanked with a row of nodes (fig. I5-I9). Unfortunately these exist in the collection only in the form of sherds, yet they exhibit something of the sculptural art of the Nacoochee potters. Other sherds show each a node projecting from the rim, flanking which was a line of round depressions seemingly made with the end of a small cane (fig. 20), and the same decorative device was employed 


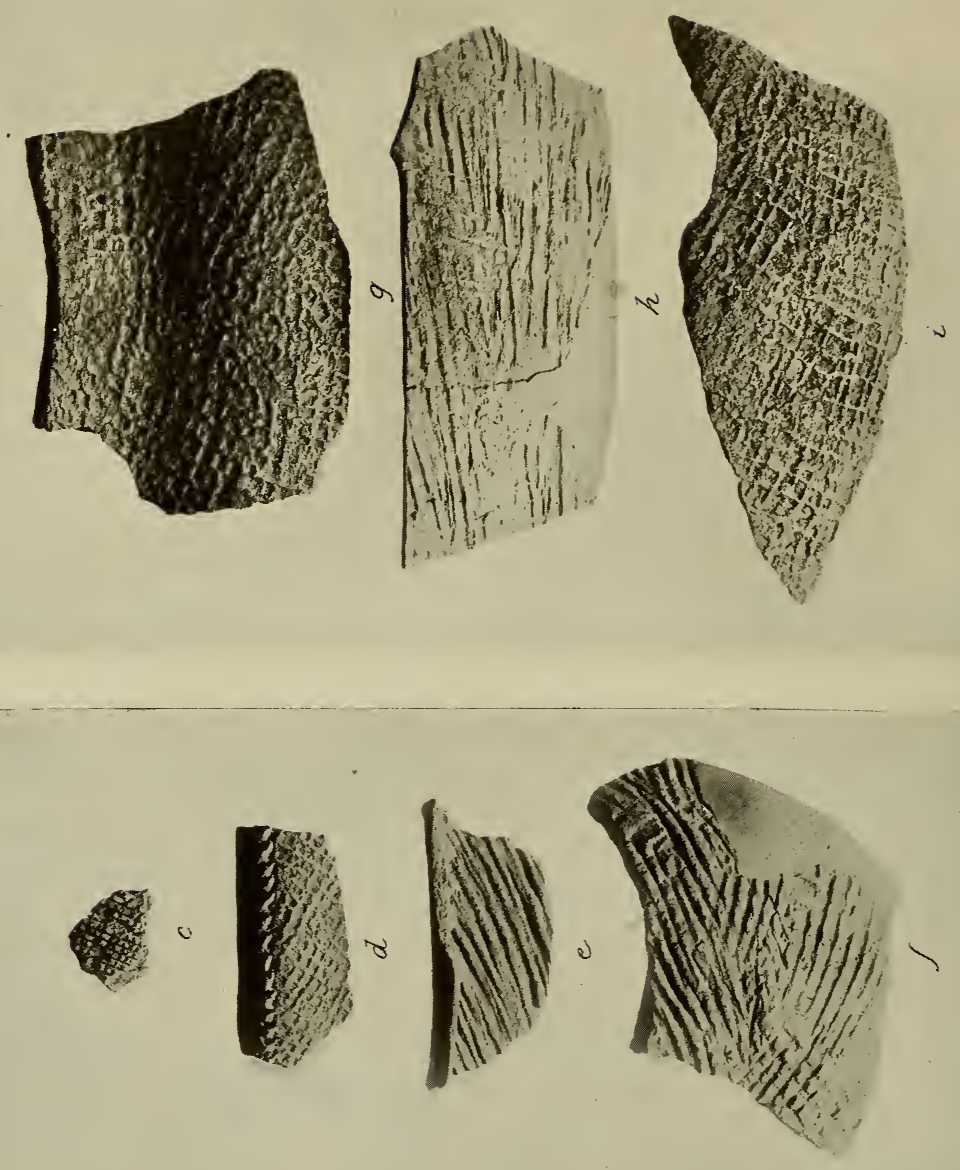

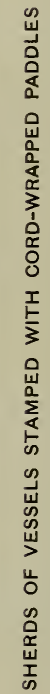

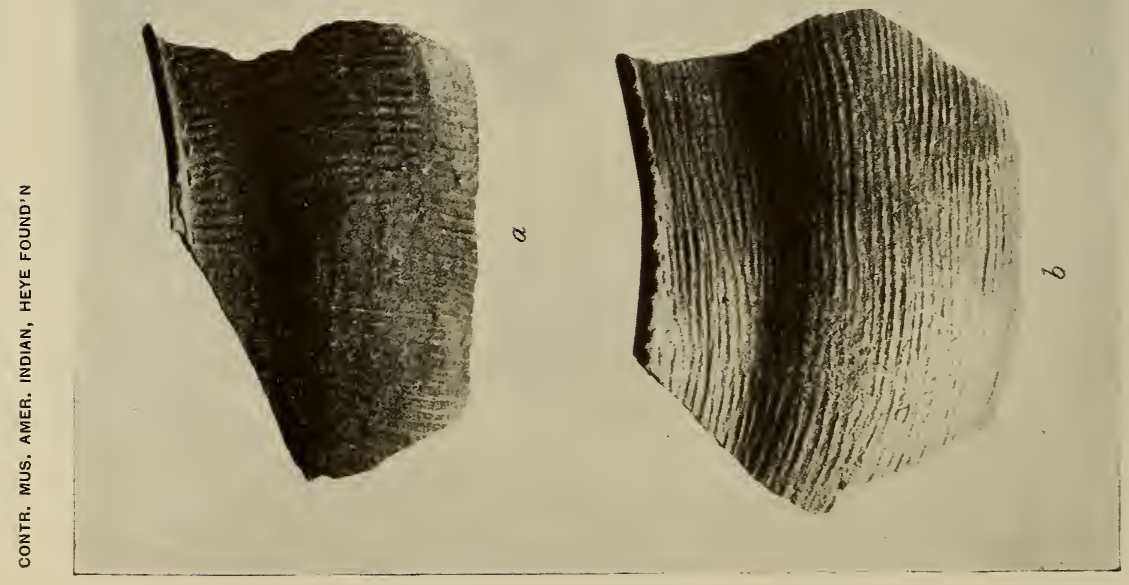


about the rims of two other vessels, one of plain red ware without additional rim elaboration ( $\mathrm{pl}$. xxIII, $c$ ), the other containing a more deeply punctured series of holes (made probably with a small blunt

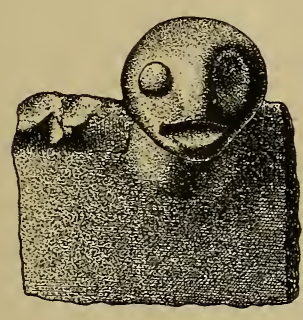

FIG. I9.-Grotesque head on rim of vessel.

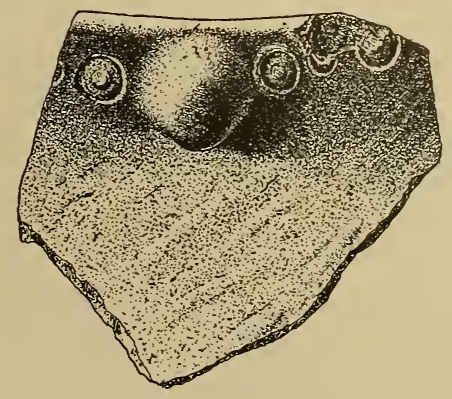

FIG. 20.-Node and punctate decoration.

twig) which appear on a ridge forming the rim, the holes terminating at a prominent node which projects therefrom (fig. $2 \mathrm{I}$ ). It is difficult to distinguish these devices from the knob handles to be described; indeed the modeled heads referred to were doubtless designed primarily for utility, since they would have served the same function as the simple knobs or lugs often found on rim fragments from Nacoochee and elsewhere, to be mentioned later.

Another form of decorative border was produced

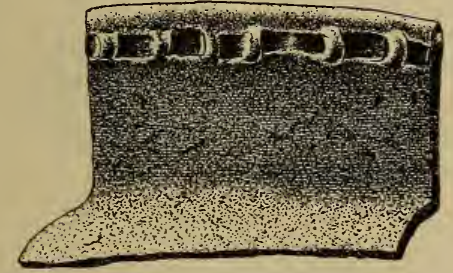

FIG. 22.-Rim ornamented by punching the clay with a cane.

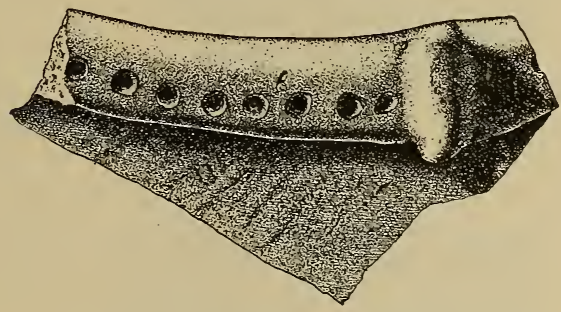

FIG. 2I.-Rim with node and punctate decoration.

by punching the clay, while moist, with the end of a cane or other tube as shown in fig. 22, which presents an ornamental band made by cutting out the alternate spaces with a small sharpened cane that left the grain of the edge impressed in the clay. 
A sherd of an unusually thick vessel whose wall measures nearly three-eighths of an inch below the lip, is also of exceptional plainness of rim, which was simply rounded over in the form of a heavy lip, without any ornamentation (pl. xxIv, q). Somewhat related in

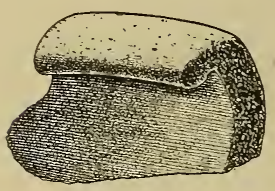

FIG. 23.-An incurving rim.

form is the rim of another vessel whose only ornamentation consisted of series of incised triple oblique lines, alternating right and left (pl. Xxiv, a). A diagonal punctate decoration, effected by means of a small hollow cane or twig, appears near the edge of the flaring rim of a sherd shown in plate xxIv, $f$. In only one specimen, a small sherd of reddish ware, does the rim curve inward (fig. 23).

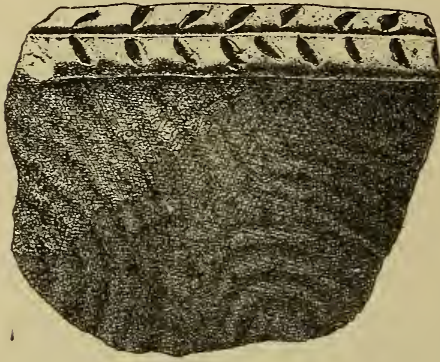

24

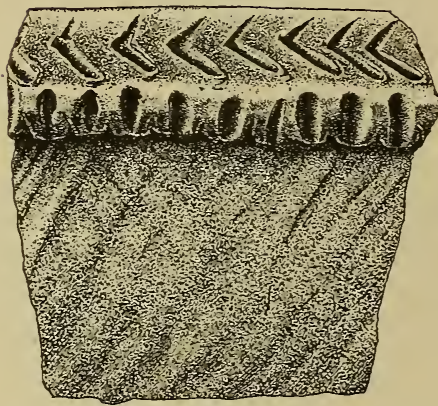

25

FIGS, 24-28, - Shouldered rims with incised decoration.
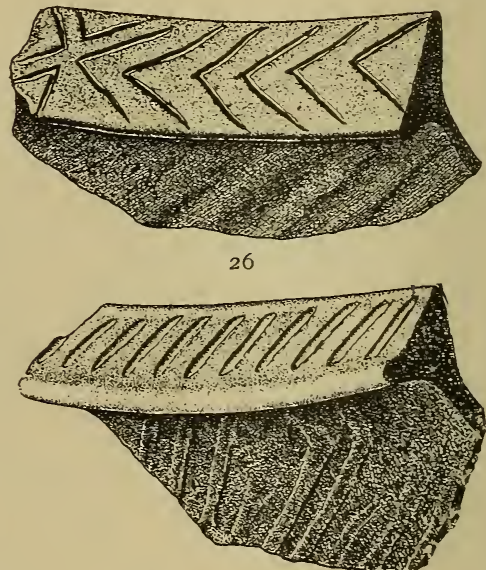

27

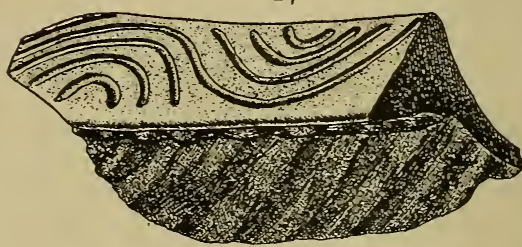

28

The rims thus far described bear their ornamentation on the face or side, beneath the edge. There are a few sherds, however, 


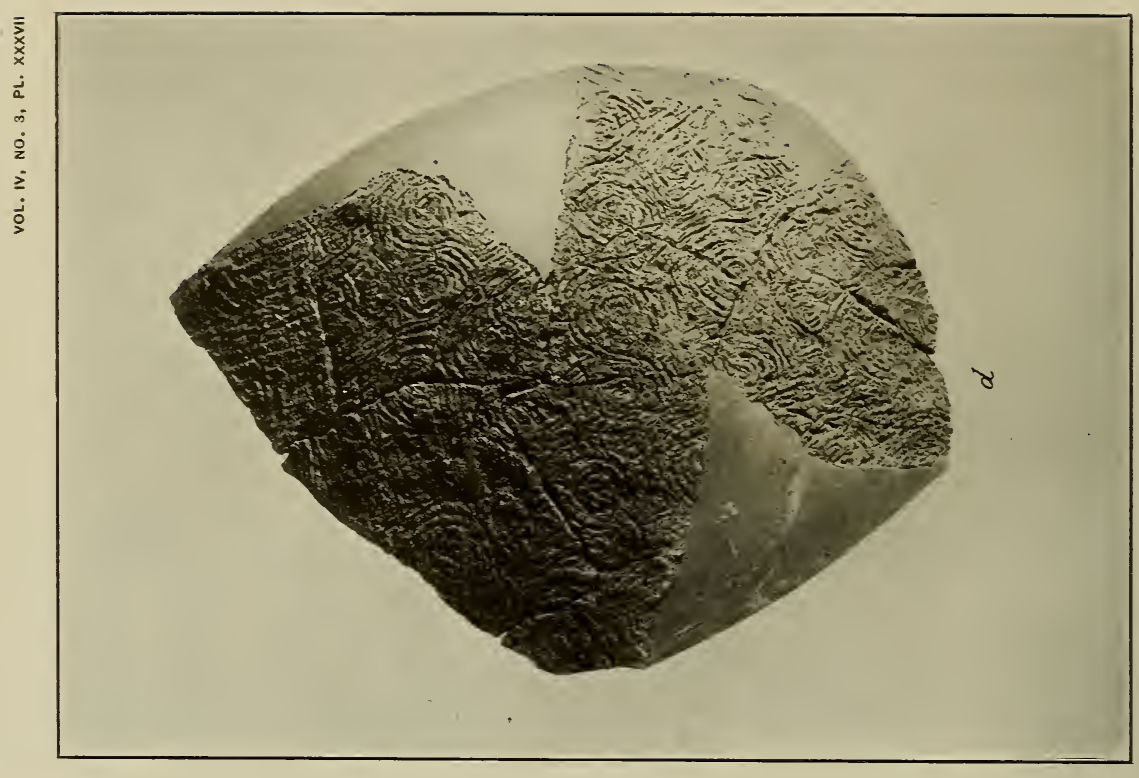

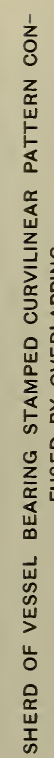

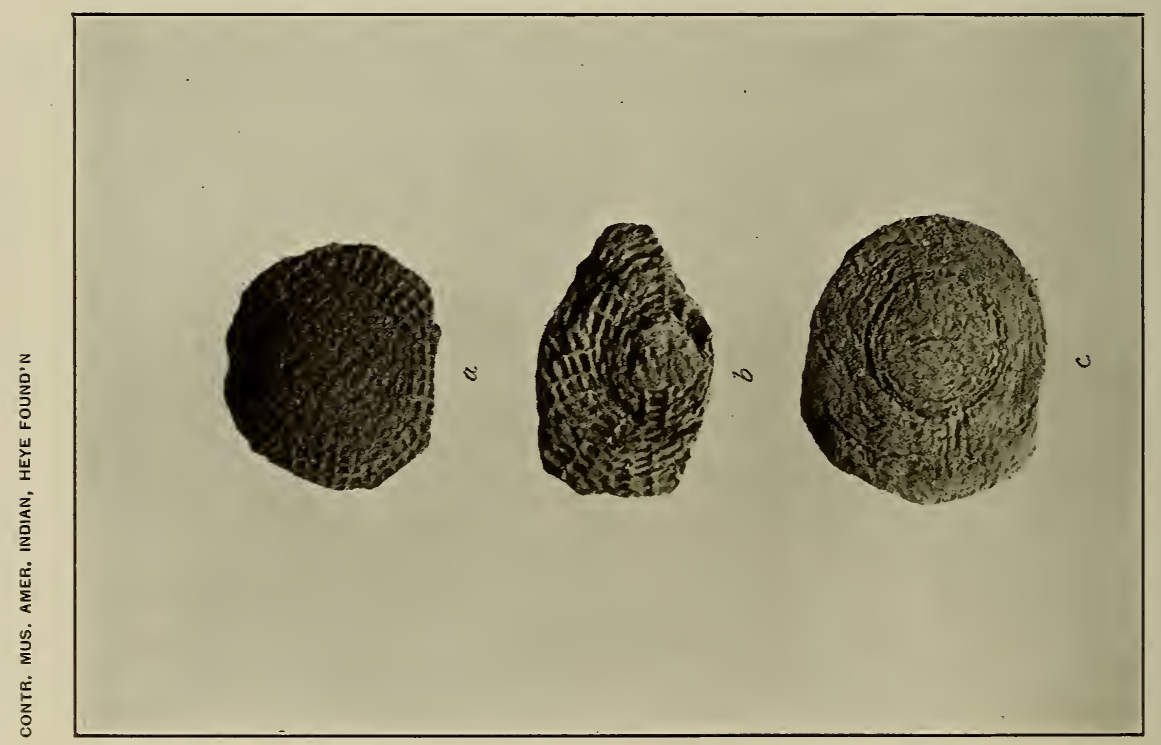

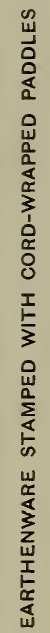


that show a decided shouldering or squaring of the rim, the neck of the vessel extending downward from the center of the rim in every instance but one. This square lip is embellished with incised devices, as shown in figs. 24-28. Three of these examples exhibit parallel acute angles directed the same way; one consists of parallel vertical lines; another, of a central horizontal line bordered on each side with depressions made apparently with the end of a small sharpened stick; while the most elaborate pattern of all

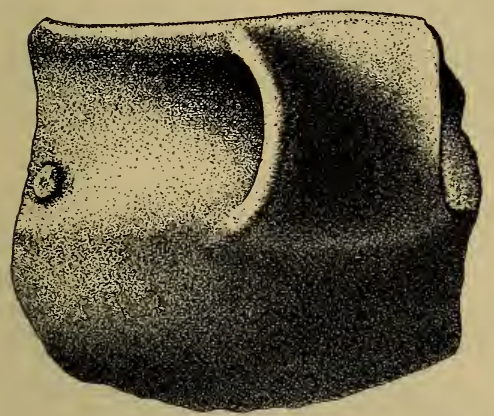

29

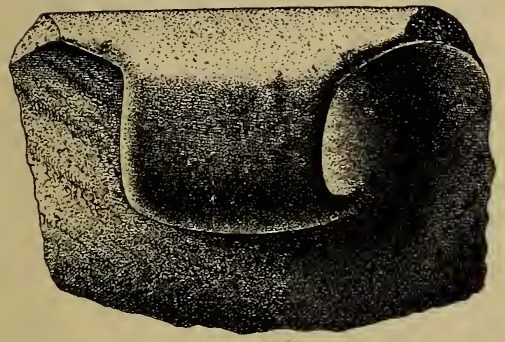

$3 I$

FIGS. 29-32.-Plain loop handles.

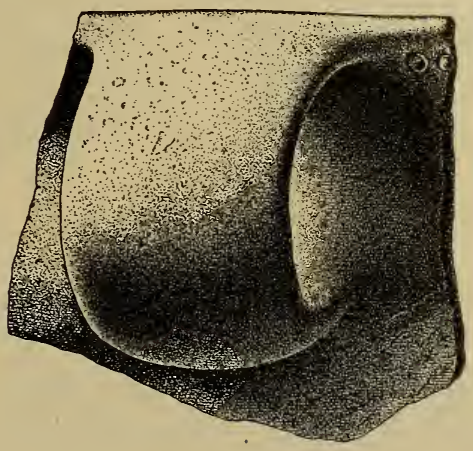

30

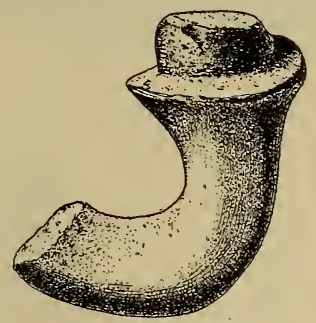

32

consists of a compound curve with shorter parallel curves occupying the semicircular spaces thereby produced.

Handles.-For convenience, the vessels were sometimes provided with handles, as above mentioned; often these were so rudimentary as to be mere knobs, but in some instances they were elaborated. These appurtenances may be designated as (a) loop handles, $(b)$ ridge handles, and $(c)$ simple knob handles. 


\section{MUSEUM OF THE AMERICAN INDIAN, HEYE FOUNDATION}

The loop handles are sometimes plain, although the vessels to which they belonged may have been fully decorated with stamped

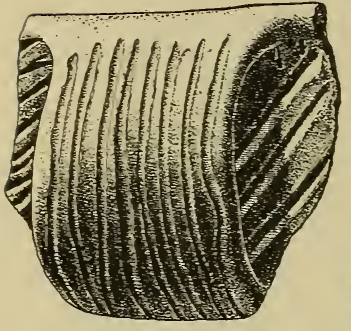

33

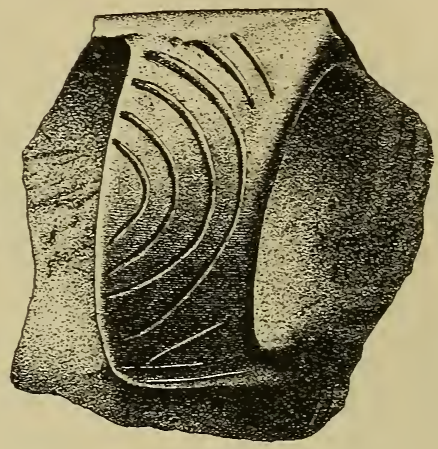

34

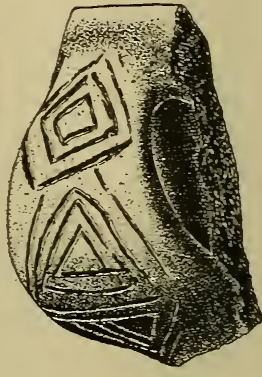

35

FIGs. 33-35.--Loop handles with incised ornamentation.

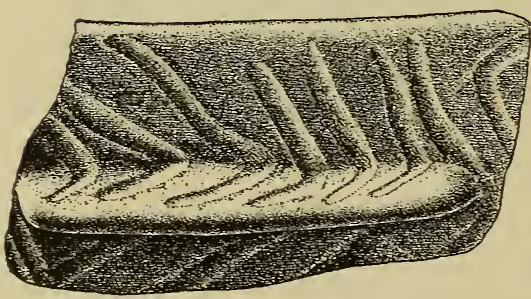

36

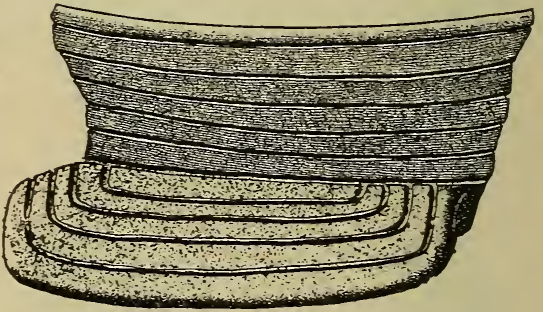

37

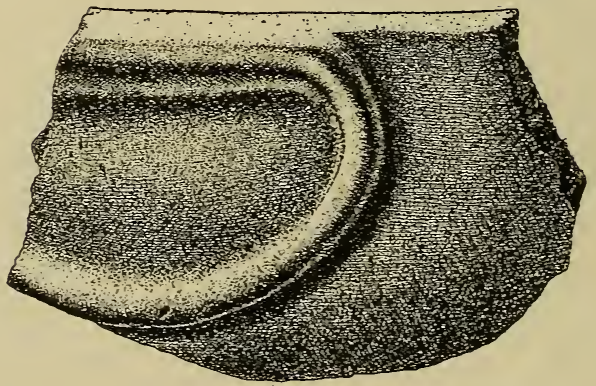

38

FIGs. 36-38.-Sherds of vessels with ridge handles.

or incised patterns; in other cases the loops are themselves ornamented with straight or curved incised lines, or with small depres- 



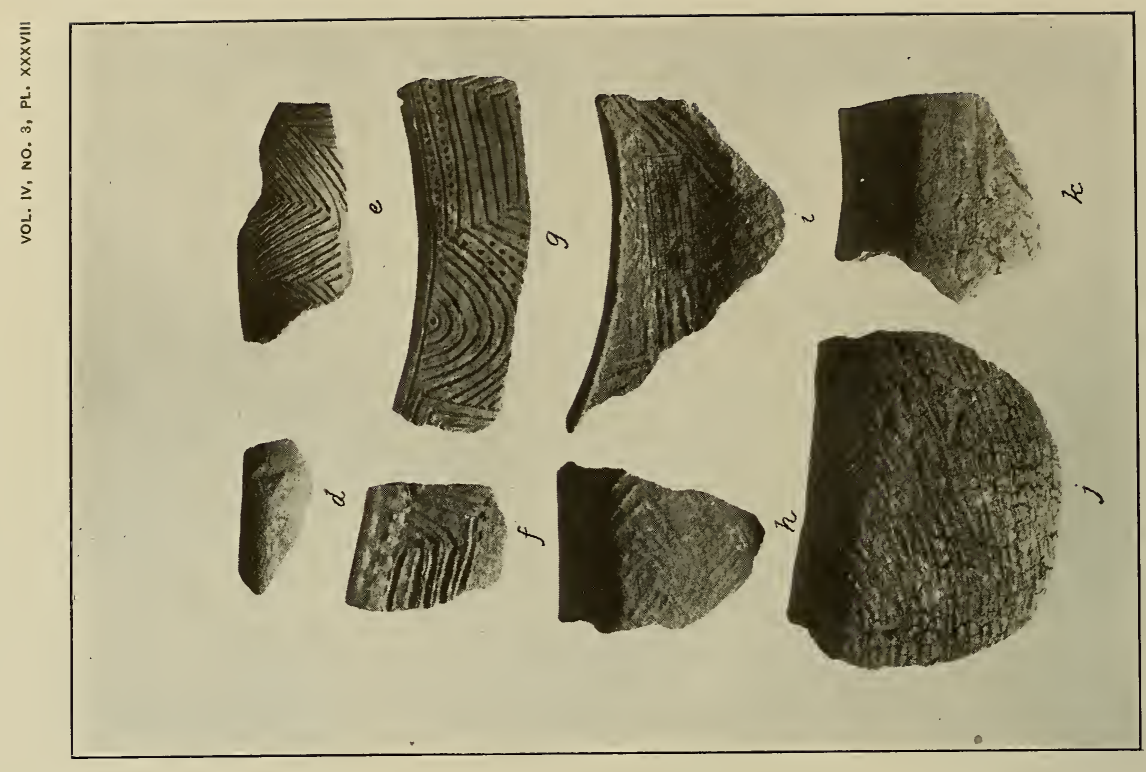

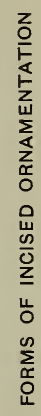




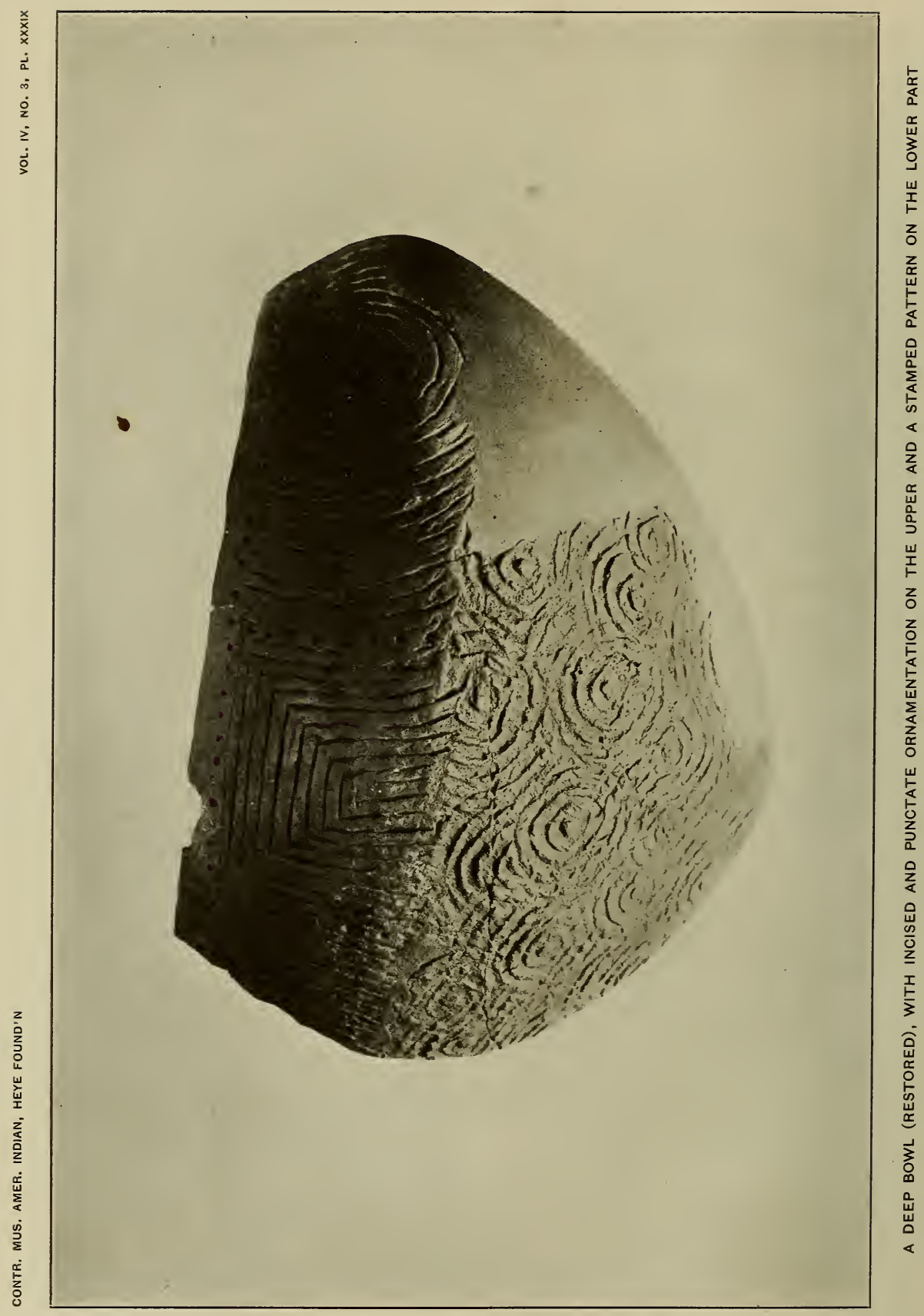


sions, but in none of the specimens is the handle ornamented by stamping, for the obvious reason that the moist clay of the loop would not have withstood the pressure. Examples of loop handles are illustrated in pl. xxv, $a$, and in fig. 29-35. The method of

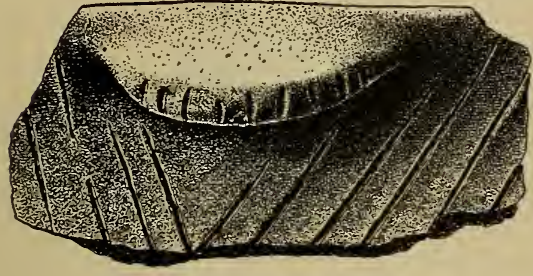

39

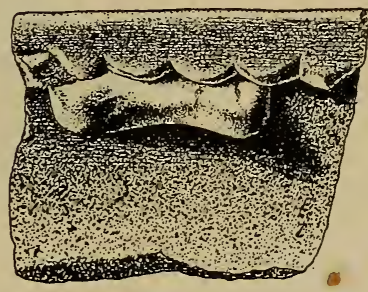

40

fastening one type of loop handle to the wall of a vessel is shown in fig. 32.

Ridge handles consist of elongate projections beneath the rim. They are plain or ornamented, and sometimes are hardly distinguishable from the rim itself. Specimens are shown in pl. $\mathrm{xxxviII}, b$, and in fig. $36-38$.

Knob handles are more or less similar to the ridge handles, but are shorter. Examples are illustrated
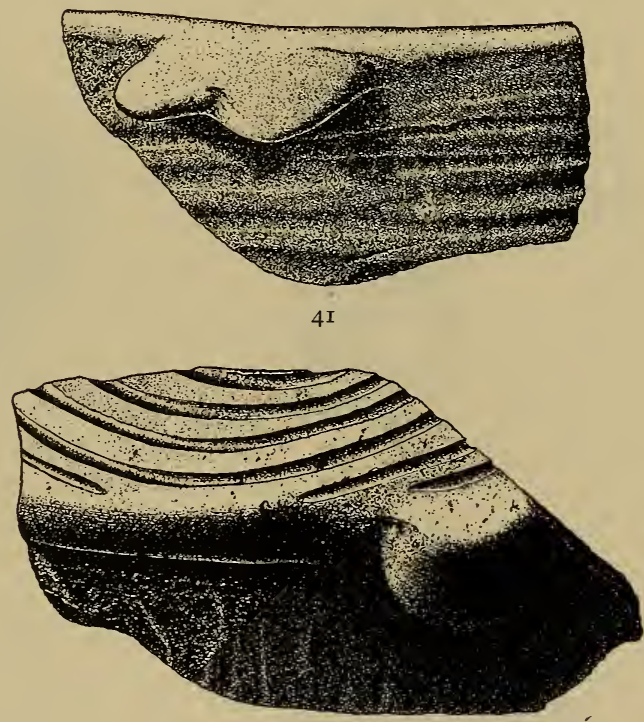

$4^{2}$

FIGS. 39-42.-Sherds of vessels with knob handles. in pl. XVII, $b$; xxII, $d, f$, and fig. 39-42.

We have already mentioned certain small effigies in connection with the description of the rims of Nacoochee utensils and which 
doubtless served the purpose of handles. The figurine resembling the head of a dog (fig. 44) was probably broken from a vessel,
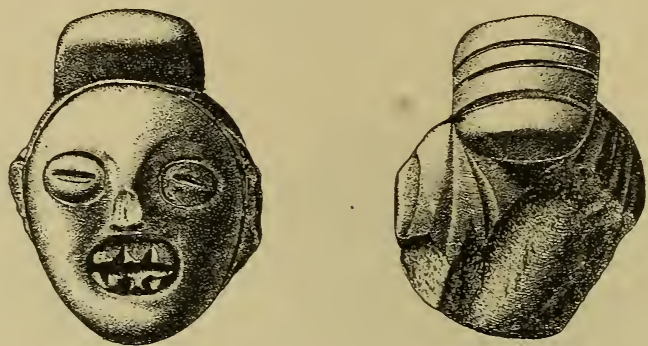

FIG. 43.-Grotesque human head of earthenware.

although what would have been the point of contact, if such were the case, is too much worn to make the determination of such use

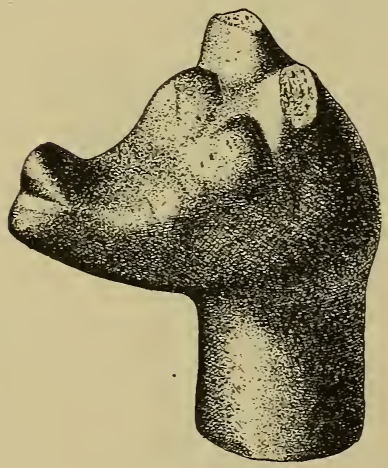

44

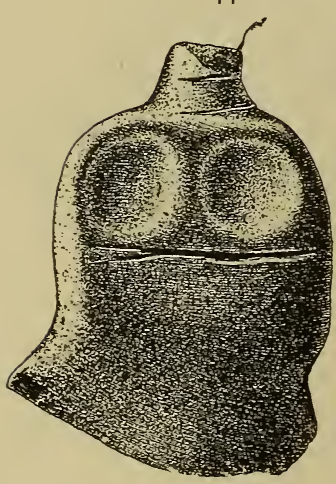

46

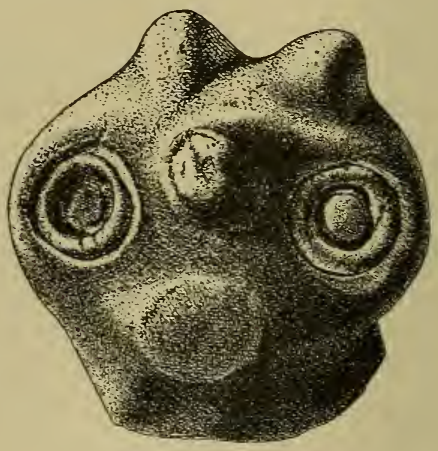

45

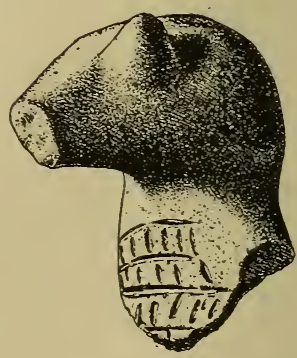

47

FIGs. 44-47.-Animal heads of earthenware from the rims of utensils. 


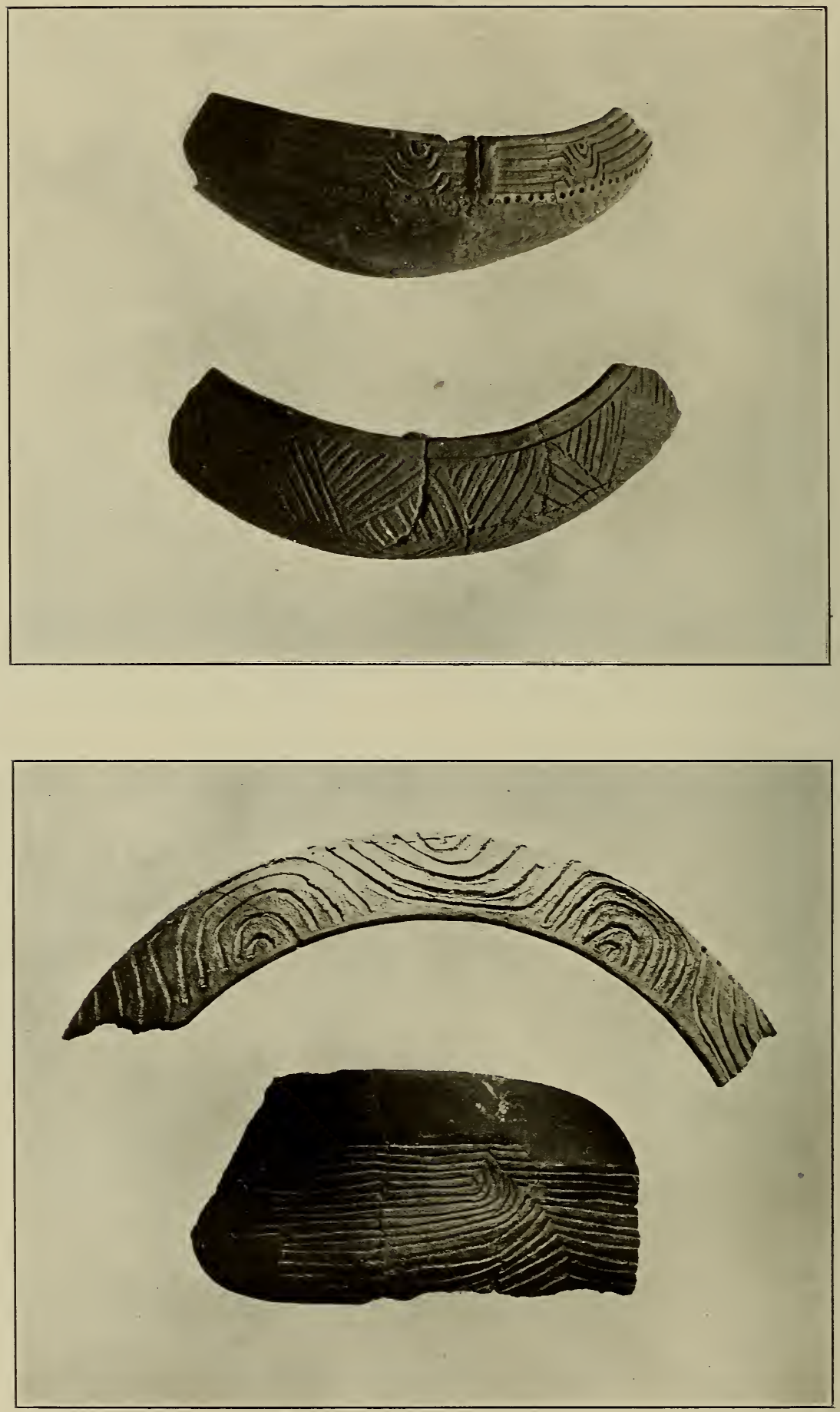

EXAMPLES OF INCISED ORNAMENTATION 
certain. The well-sculptured grotesque human head (fig. 43) was probably used either for a similar purpose or else adorned a pipemore likely the latter, as the ware is well polished and of the superior quality characteristic of the manufacture of pipes rather than of domestic utensils. An interesting feature is the head-dress, represented as a triple-banded fillet above the crown. On the other hand, the relatively rude owl-like head (fig. 45) was probably broken from the rim or neck of a large cooking-pot, and the same is true of the grotesque sculpture of red-burned clay represented in fig. 46, which possibly represents the head of a soft-shell turtle. ${ }^{1}$

\section{ORNAMENTATION}

Stamped Patterns.-Particular attention was given by the makers to the ornamentation of their pottery with stamped patterns or with incised designs, and in numerous instances both of these modes of embellishment were employed on the same vessel, in these cases (if we may safely make an imaginary restoration of some of the utensils) the etching being confined to the upper portion.

The stamped ornamentation of vessels, however, seems to have been preferred to the incised variety, probably because this method was more easily applied, for when once the stamp or roulette bearing the negative of the design or ornament was fashioned, its use by any potter usually required little more than mere mechanical application on her part.

As might be expected, most of the impressed ornamentation is in straight-line patterns; but there are also numerous examples of curved figures, and some sherds exhibit a combination of the straight and the curved. As a rule the attempt was evidently made to stamp the pattern in to the plastic clay without overlapping, but often the impression was so carelessly made as to confuse the repeated design, and there are instances in which the paddle had been applied so promiscuously as to destroy the pattern almost completely.

Typical examples of straight-line patterns are illustrated in pl.

${ }^{1}$ Earthenware bowls with similar grotesque heads in place are illustrated by Thruston, Antiquities of Tennessee, pp. I40-I54, Cincinnati, I890. 
$\mathrm{xxV}-\mathrm{Xxx}$, which convey a more adequate idea of the character of this style of stamped ornamentation than a mere description.

Some of the designs were stamped into the moist clay during the process of manufacture by means of earthenware paddles, as shown by portions of five of these illustrated in pl. xxxr. No entire paddles were found. Wooden implements also were used for this purpose; indeed on some vessels the grain of the wood shows quite distinctly between the relief lines of the ornamentation. The fragmentary pottery stamps referred to are incised on both sides, in one case $\left(d, d^{\prime}\right)$ the pattern being somewhat similar on the two faces, while in another $\left(c, c^{\prime}\right)$ practically the same design is seen on one side, while on the other an attempt has been made to produce a spiral-like figure, so frequently found on Nacoochee receptacles. No impressions from any of these particular pottery stamps have been found on any of the hundreds of sherds examined, but there are many that bear patterns of the same general types.

The section shown in pl. $\mathrm{xxx}$ illustrates part of a sherd of a very large jar which seems to have been ornamented by covering the face of the pottery stamp with a piece of thin cloth, which left its impression in the depressed parts of the design on the pottery. The portion of the pattern in relief was evidently smoothed with the hand in vessels with more deeply incised ornamentation, at least, and doubtless the same practice was followed in the case of the stamped decoration, as in pl. xxxvir, $d$, for example, for the purpose of removing any rough or sharp edges.

The stamped ware with curvilinear ornamentation is somewhat less common than that with straight-line or rectangular patterns, yet many hundreds of sherds of this variety were taken from the refuse. Most of the stamped ornamentation of this type was crudely applied, and, as in the case of the straight-line or angular decoration, care was not always exercised in avoiding overlapping of the pattern. Some of the impressions are very coarse, due both to the crudeness of the stamps and to the inexpert manner in which they were applied. On the other hand, some of the fragments exhibit care and esthetic merit, the stamps having been carefully designed and prepared, and the stamping done with considerable 


$$
\text { - }
$$




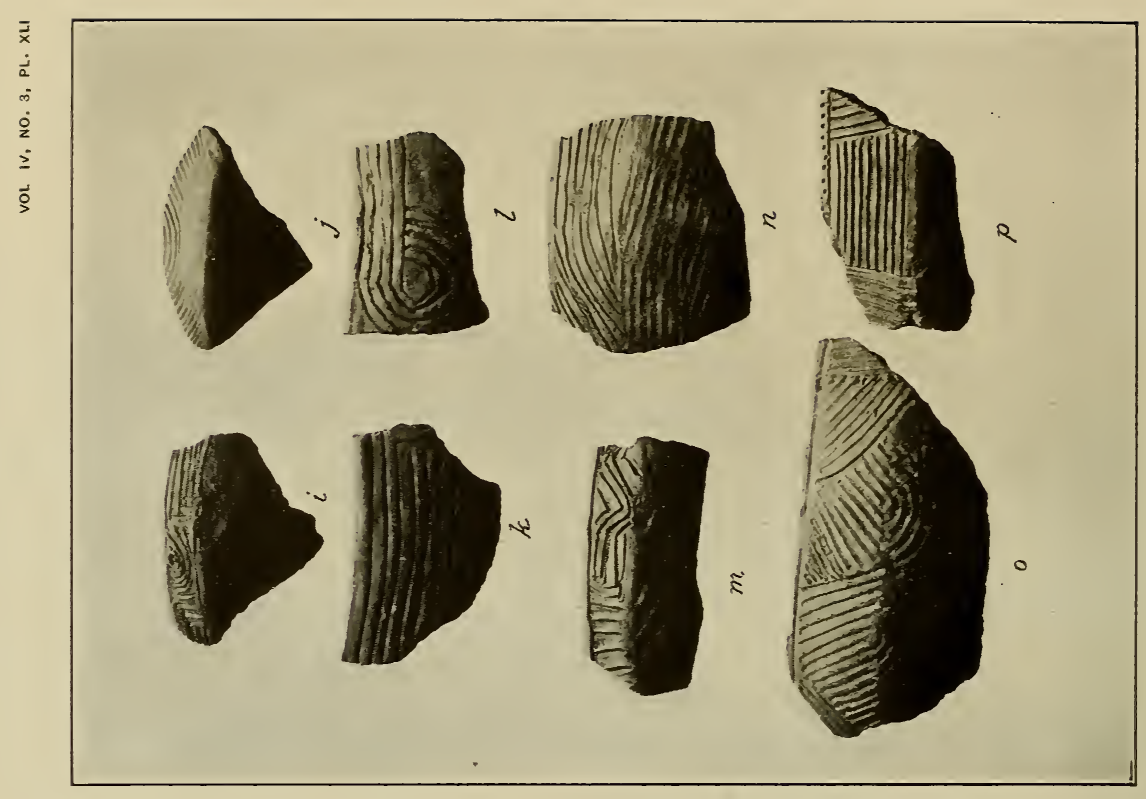

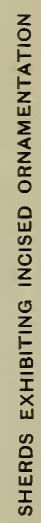


skill. A selection showing the range of curvilinear patterns is presented in the accompanying illustrations (pl. XVII, $a, c$; XxxII$\mathrm{xxxv}$ ), which will afford a further idea of the artistic attainment of the Nacoochee potters.

A class of stamped ware that is likely to mislead one as to the manner in which the ornamentation was applied to the surface of vessels is characterized by horizontal, vertical, or oblique lines, sometimes crossed by other lines, produced by wrapping the paddle or roulette with cording made of vegetal fiber. Examples of these are shown in pl. xxxvi. In addition, there are specimens similarly stamped, but with a paddle on which was carved a series of small squares or rhombs and which had been so well manipulated as to give the appearance of basketry or of netting. Close study, however, of both these forms of surface treatment on sherds sufficiently large for observation, shows that they consist of repeated designs or patterns, in some cases more or less broken or overlapped. The fragments of the bottoms of jars shown on pl. xxxviI, $a, b$, are especially deceptive, both having the appearance of basket impressions, but which in fact were stamped as in the case of the other sherds referred to. The last sherd to which allusion is made, which is part of a vessel that had been considerably worn (pl. xxxvII, $c$ ), shows what appear to be the joints of the coiling process which the stamping had not wholly obliterated.

Incised Decoration.-The last type of pottery decoration to be considered is represented by the incised ware, or by a combination of incised and stamped. This method of ornamentation was applied chiefly to the upper part of bowls, forming a band below the rim; but a notable exception is the large jar to which allusion has already been made (pl. xvII, $b$ ), which is coarsely incised from the neck to the middle of the body with bold, broad, parallel angles, the lines forming the alternate groups of angles being long and short, and the apex of the outer angles of the alternate groups pointing respectively upward and downward. The scoring of the clay of this receptacle was done with a round-pointed instrument. In addition to two opposite rows of five nodes, each forming the decorative feature of the rim, there are, between these rows, two pairs of larger 
nodes, also opposite each other, which evidently were designed to facilitate the lifting of the vessel, and therefore are a form of the knob handles already described. We may here mention that the clay of which this interesting jar was modeled was liberally tempered with shell, small flakes of which are visible inside and out.

The patterns employed in the incised work (pl. xvII, $b$; xIx; XXXVIII-XLII) consist of both straight and curved lines, scrolls, fret-like figures and concentric circles, worked out in varying combinations and in a few cases accentuated with punctate dots or with impressions made with the end of a cane-stalk. In some examples the lines, whether straight or curved, are extremely crude, having been etched with little control of the implement employed; in other specimens the workmanship is well executed and the result pleasing. It is not always possible to determine the kind of implement used in making the incised ornamentation, but some of the designs no doubt were produced by means of a graver of cane, the lines of which are quite apparent. In other examples it seems equally evident that anything handy might have been employed for scratching the lines, like a stick or a twig, and while sometimes no attempt was made to smooth the rough edges, the scorings were
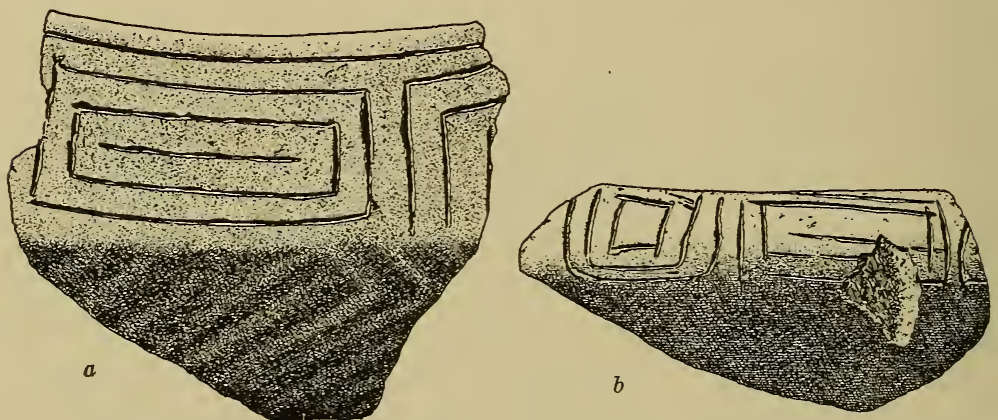

FIG. 48.- Sherds showing incised ornamentation.

often carefully routed, leaving the incisions clear and sharp. In two of the specimens illustrated (pl. XxxviII, $a$, and xxxix) the surface was pressed after the design was incised, as if to smooth away the roughened edges caused by the graving tool. In several sherds the etching, or more properly scratching, of the orna- 


$$
\text { - }
$$




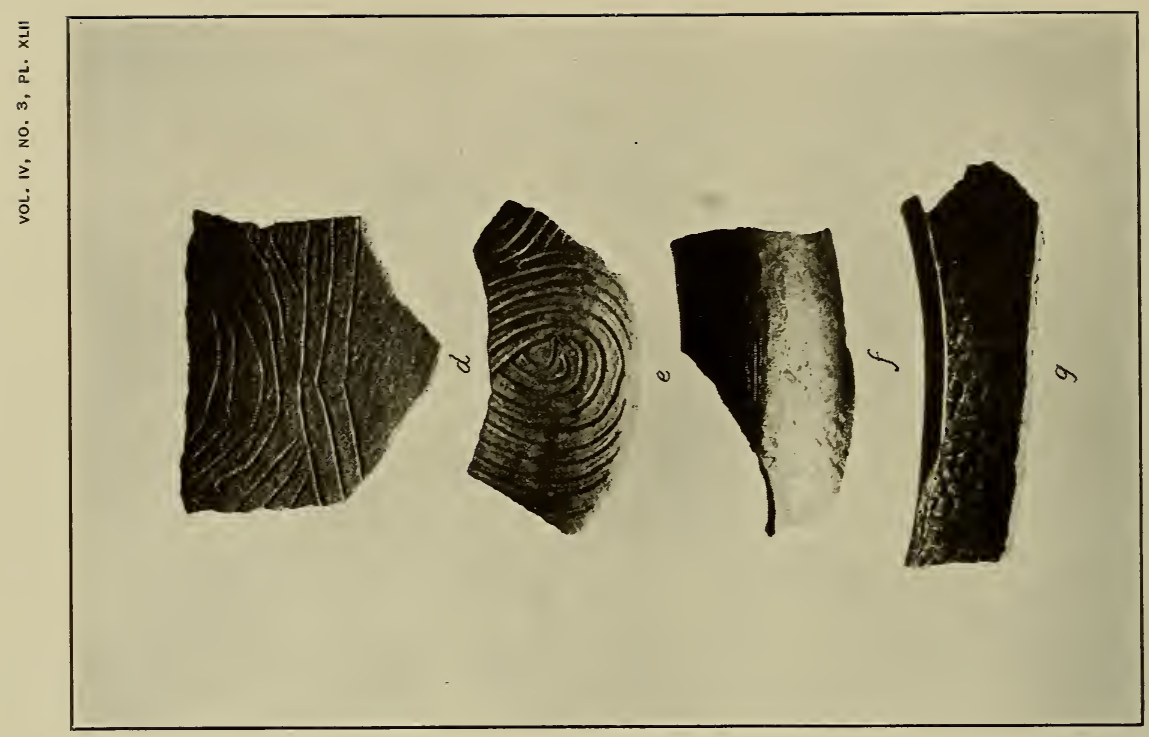

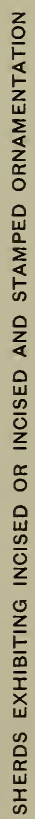


mentation was effected with a sharp implement, in several examples illustrated (pl. xxxviII, $d, i, j, k$, and fig. $48, b$ ) the work having been done so crudely as scarcely to be worthy the effort of children:

While incised work was confined usually to the rims and the exterior portion of the necks of bowls, an exception is noted in a single sherd of a jar of reddish ware that had been scored rather deeply with parallel diagonal lines within the neck.

Regardless of the skill or the lack of skill exhibited by individual potters of Nacoochee, they manifested high regard for the ornamental, for only in exceptional instances did they fail to embellish their earthenware vessels with the best their esthetic sense inspired. Indeed they devoted as much attention in this respect to some of the coarsest ware as to the finest products of their ceramic art. In view of this fact it is strange that these people paid no attention to ornamentation of their pottery by painting, the painted effigy vase hitherto described doubtless being intrusive.

\section{MISCELLANEOUS POTTERY OBJECTS}

Certain pins or plugs of earthenware, two of them entire (fig. 49), the remainder represented only by stems and heads, are among the earthenware objects from Nacoochee. Such plugs are supposed to have been used to keep open the freshly-pierced lobes of the ears preparatory to the insertion of permanent ornaments of shell or other material. Such ornaments are mentioned and illustrated in connection with the description of shell artifacts (p. 93).

Beads of pottery are uncommon, only three having been found (fig. 50). The largest of these $(a)$ is tubular, eleven-sixteenths of an inch long and

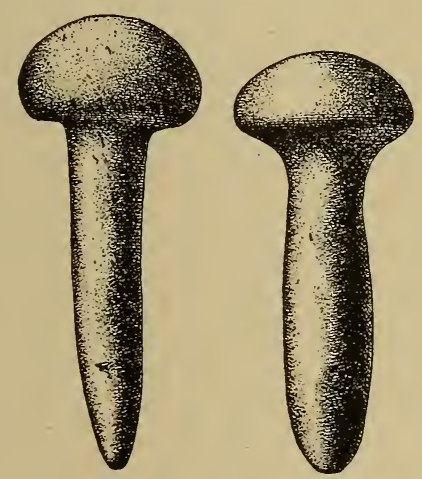
painted red outside. Probably this was not designed originally as a bead, but was cut from the broken stem of a pipe. The 
other two, however, were originally made as beads. One $(b)$ is almost spherical, with a greater diameter of half an inch, and is of the reddiș color of the burned clay; the other $(c)$ is elongate, fiveeighths of an inch in length, and flattish; both are crudely made, no attention having been given them beyond rolling or patting with the fingers.

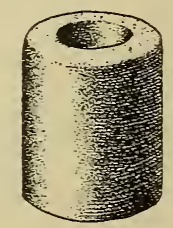

$a$

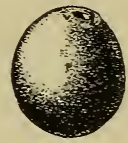

$b$

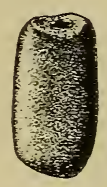

$c$

FIG. 50.-Beads of earthenware.

A biscuit-like object of pottery, $\mathrm{I} 3 / 4 \mathrm{in}$. in diameter and averaging three-quarters of an inch in thickness, rudely modeled and blackened by firing (pl. Xxil, e), may have served the same purpose as some of the discoidal stones to be described.

Discs chipped or rubbed from potsherds were very common throughout the mound, having been so easily made that evidently little care was taken to preserve them. In diameter they range from about three-quarters of an inch to $3 \frac{1}{4} \mathrm{in}$. and are of varying thickness. Sherds of any kind were used, little effort having been made to select well-finished fragments or those bearing attractive patterns; indeed in most cases the discs are of crude ware, indicating that the sherds were picked up at random and that perhaps weight rather than quality or finish was the desideratum. As might be expected, there is a greater proportion of ornamented than of plain pieces. Pottery discs of this kind are generally supposed to have been used in gaming. Owing to the disparity in their sizes, it may be presumed that the smallest ones were employed as counters. A few examples are shown in plate xLIII. These objects grade into a class of rude stone discs to be described, and in all probability were used for the same purpose. 



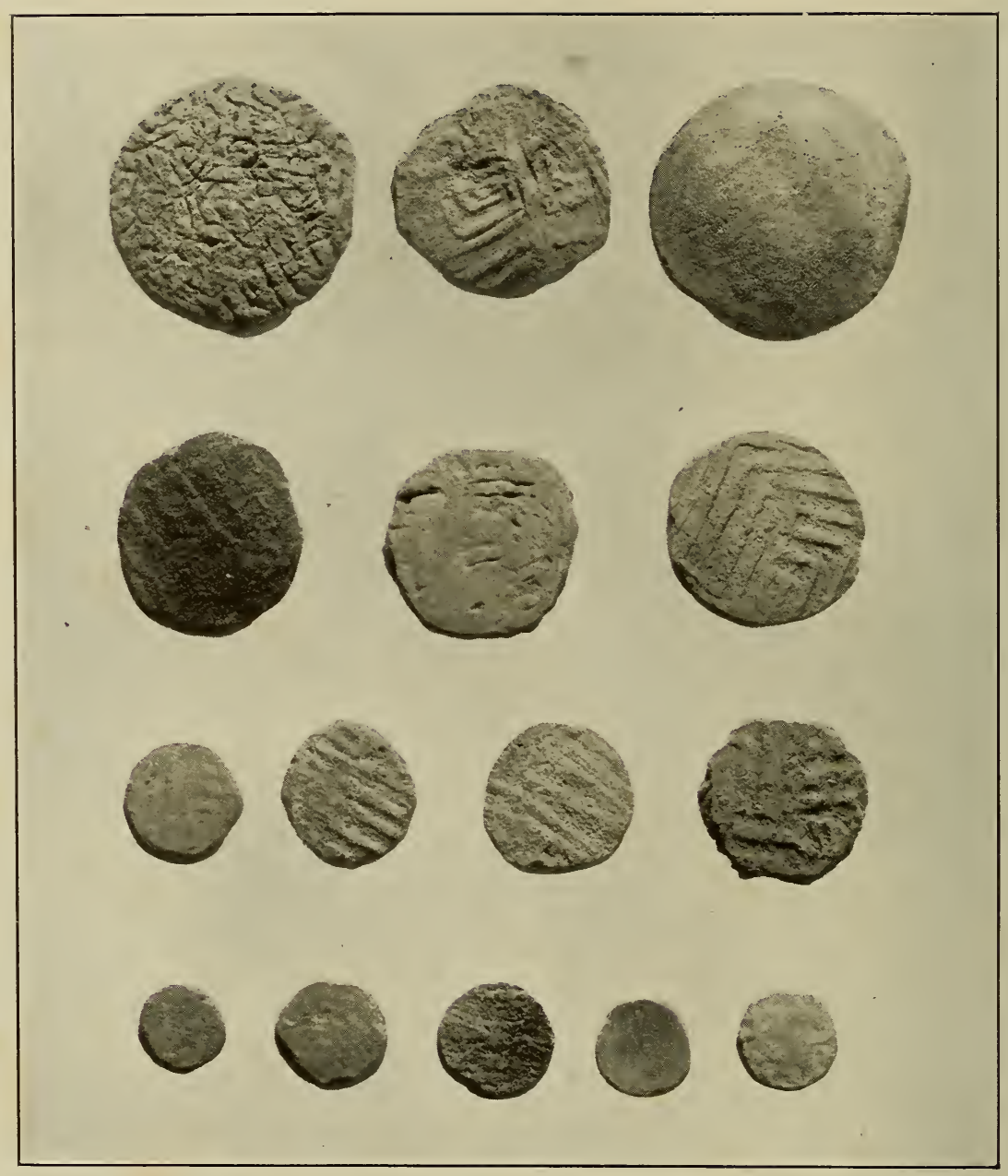

DISCS FASHIONED FROM POTSHERDS 


\section{SMoking Pipes}

\section{PIPES OF EARTHENWARE}

Whatever the esthetic attainments of the Cherokee of Nacoochee as exemplified by their pottery, they probably reached the height of their artistic ability in the manufacture of smoking pipes of earthenware and of stone. Writing of Cherokee pipes nearly a century and a half ago, Adair said:

"They make beautiful stone pipes; and the Cherokee the best of any of the Indians: for their mountainous country contains many different sorts and colors of soils proper for such uses. They easily form them with their tomahawks, and afterward finish them in any desired form with their knives; the pipes being of a very soft quality till they are smoked with, and used to the fire, when they become quite hard. They are often a full span long, and the bowls are about half as large again as those of our English pipes. The fore part of each commonly runs out with a sharp peak, two or three fingers broad, and a quarter of an inch thick-on both sides of the bowl, lengthwise, they cut several pictures with a great deal of skill and labor, such as a buffalo and a panther on the opposite sides of the bowl; a rabbit and a fox; and, very often, a man and a woman puris natur alibus. Their sculpture cannot be much commended for its modesty. The savages work so slow, that one of their artists is two months at a pipe with his knife, before he finishes it. . . . The stems are commonly made of soft wood about two feet long, and an inch thick, cut into four squares, each scooped until they join very near the hollow of the stem. . .." 1

The crowning example of artistry in pipe manufacture by the Nacoochee people is a specimen not found by our expedition but was recovered by Captain Nichols, who in 1870 unearthed the copper celt and other objects near the western base of the mound, as hitherto described. The pipe later came into the possession of Captain Nichols' daughter, Mrs George F. Payne, of Atlanta, from whom it was acquired.

The accompanying fig. 5I presents two views of this object, which is light-brown, the color of the clay, smoke-blackened on one side in firing. The bowl is covered with pyramidal facets (a favorite device in pipe ornamentation), and on the rear or smoker's

\footnotetext{
${ }^{1}$ James Adair, History of the American Indians, p. 423, London, I 775.
} 
side is surmounted by a grotesque bird figure with diminutive body, large beak, erect ears, and bulging eyes. The front of the bowl rim curves upward to a point, and the short stem is finished with a heavy serrated flange. The inside of the bowl shows the irregularly vertical marks of a finishing tool, and the stem opening,
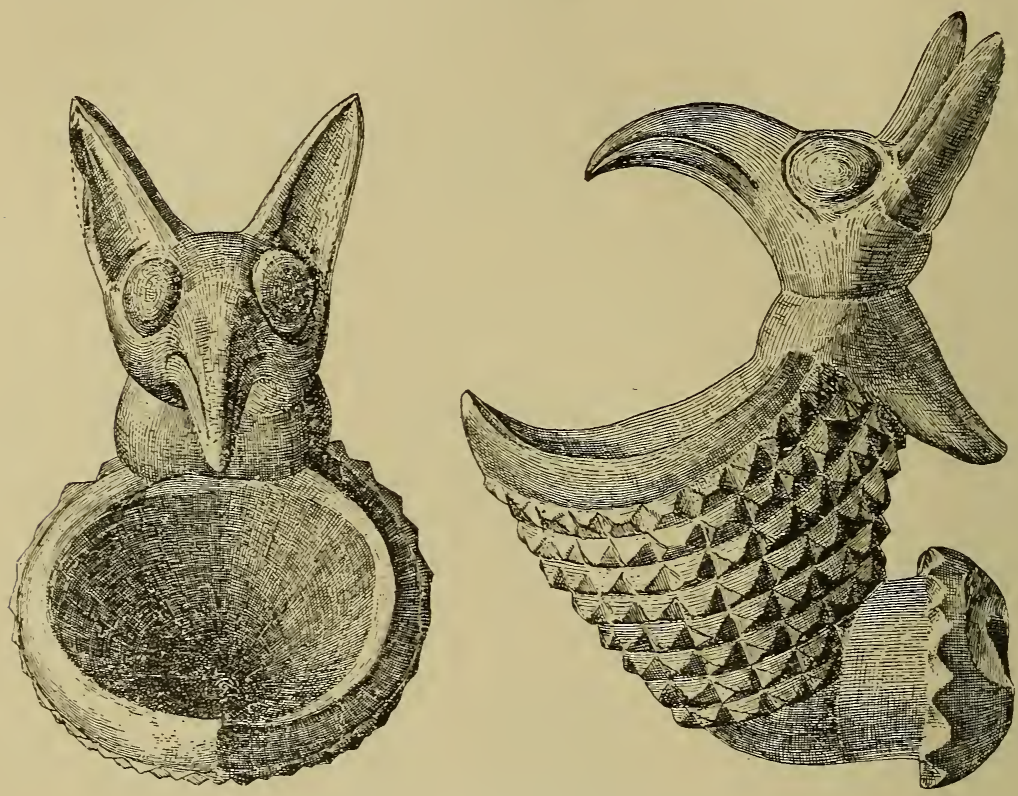

FIG. 5I.-Earthenware effigy pipe.

which tapers moderately toward the bowl, exhibits faint horizontal markings as if scratched either with a tool or in twisting the stem in place. This fine pipe, which has been illustrated by MçGuire ${ }^{1}$ and by Holmes ${ }^{2}$ from a cast in the National Museum, was probably found subsequent to 1873 , the date of publication of C. C. Jones' "Antiquities of the Southern Indians," as it is not mentioned therein with other objects found by Captain Nichols at Nacoochee. McGuire's illustration is somewhat misleading in that it represents

${ }^{1} \mathrm{~J}$. D. McGuire, Pipes and Smoking Customs of the American Aborigines, National Museum Report for 1897, fig. 237, p. 619, Washington, 1899.

${ }_{2}^{2}$ Fifteenth Annual Report of the Bureau of American Ethnology, pl. cxxv, Washington, 1903 . 


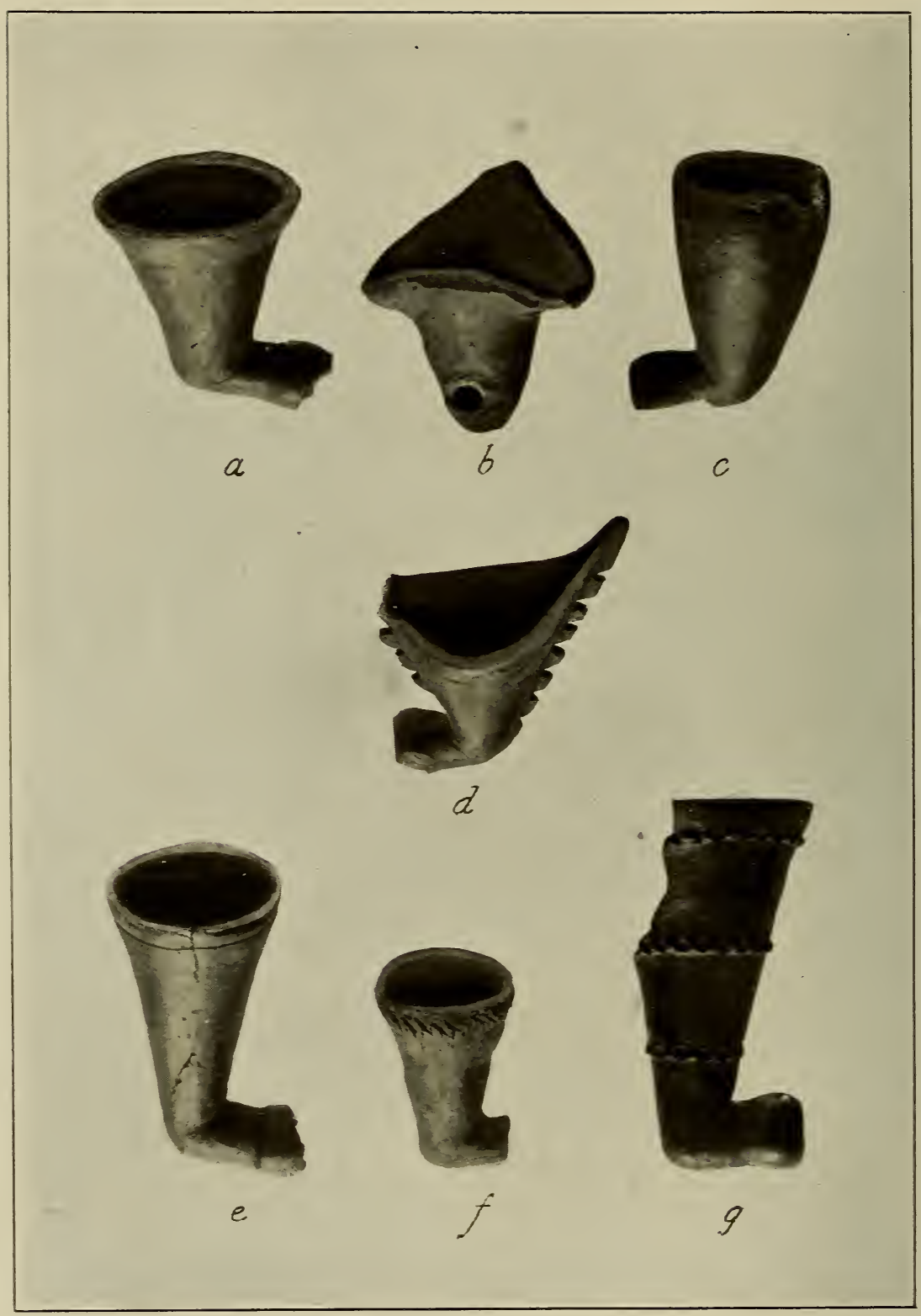

EARTHENWARE SMOKING PIPES 
the rim of the pipe-bowl as forming the legs of the bird, whereas they have no connection. The same writer states that the serrated stem band and the pyramidal ornaments on the bowl "all appear to have been cut out of the pottery subsequent to its baking." Whatever may be the appearance of the cast made years ago for the National Museum, the original pipe in the Museum of the American Indian, Heye Foundation, certainly affords no basis for any belief other than that the facets and serration were carved in the clay before the object was fired.

This effigy belongs to a favorite form of pipes from this region, the shape of the bowl resembling that of a lily, two plainer examples of which are illustrated in pl. XLIV, $b, d$. With the upward flare of the rim eliminated, we have another form $(a, e, g)$, also common at Nacoochee, which in turn merges into other pipes similar in type but varying more or less as to proportion and ornamentation. The stems are invariably short, and almost without exception have a knobbed mouthpiece, although in a few specimens the knob had been broken off, the rough edges ground away, and the pipes no doubt made to do

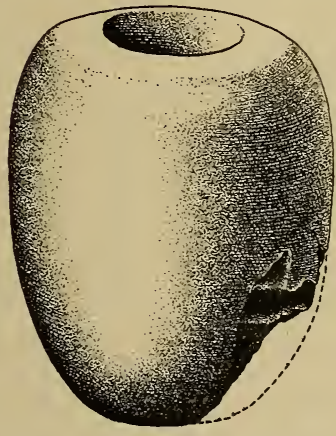

FIG. 52.-Earthenware smoking pipe. further service. The need of a thickened end to give strength to the pipe when the cane stem was forcibly inserted is apparent. The rather heavy pipe-bowl illustrated in fig. $5^{2}$ was supplied with a cane stem only.

The quality of the clay of which the pipes were made, as well as the tempering, is variable; some of the specimens are of excellent ware and were carefully and artistically modeled, but others are of the crudest description, especially two found with Burial I2, as if they had been designed to serve a temporary or funerary purpose. The finer ware seems to have had little or no tempering agent, and like the pottery utensils above described, paint was not employed as a decorative medium, if one may except three small pipe fragments on which traces of red paint, probably hematite, are seen. 
One of these is part of the head of a bird whose mouth is colored red within.

The decorative features of some of the pipes are shown in illustrations to which attention has already been directed. Unfortunately many other examples are in fragmentary condition, but with knowledge of the form of some of the pipes it is not difficult to make an approximate reconstruction, in the mind's eye, of the complete features of some of the effigy and other figures with which the makers of the pipes embellished these cherished objects.

Most notable among the sculptures in clay is that of the bird on the pipe to which attention has already been given, and unfortunately this is the only complete specimen. Of sherds, however, we are able to present a few examples of bird forms, all but one of which are represented with serrate crests and all with prominent eyes. There is no doubt that these fragments (pl. XLvIr) are parts of the rims of pipe bowls. A wolf-like head which, judging by the area of separation from the ware to which it had been attached, was probably part of a pipe; at any rate the curvature of what had been the point of contact is such that the head must have been fastened to a very small body. This head (shown in the central figure of pl. XLVII) bears traces of red paint.

We have already called attention to the use of a field of pyramidal facets as a feature of pipe ornamentation. Of this device several examples were preserved, varying in no particular from the ornamentation found on the body of the fine pipe first described, but applied also in the form of decorative bands or borders and merging into either closely grouped or isolated nodes of conventional or irregular form (pl. XLVII-XLVIII). Punctate or pressed markings, perforations, incisions, and pits were employed likewise as a means of ornamenting the pipe bowls, the treatment in some specimens resembling that of the rims of certain domestic utensils. Only a few of the many applications of these processes can be illustrated.

Perhaps we may regard the loop that terminated the rim of various pipes to have been more useful than ornamental, since it served as a means of attaching the pipe to the person. A few forms of plain loops are presented in pl. XLVII. We have already observed 


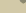



that three of the bird heads which formed the terminal projections of certain pipe rims bear apertures through the beaks, while another has the eye completely punctured, evidently likewise to afford a means of suspension.

\section{TRADE PIPES}

Various fragments of ordinary white clay trade pipes were found in the upper part and under the slopes of the mound. One of these bears a part of the manufacturer's mark on each side of the heel, the letters seeming to be an $\mathrm{M}$ and a $\mathrm{W}$, but even these are not distinct.

\section{STONE PIPES}

While there are a few excellent stone pipes from Nacoochee, the specimens of this material as a whole do not compare favorably with those of earthenware. The catlinite pipe shown in pl. XLIX, $a$, found with Burial 2, lying $2 \mathrm{ft} .9$ in. beneath the surface (see pl. XIV, $a$ ), is noteworthy both by reason of its form and finish and because it is the only specimen of pipestone found in the mound; indeed Jones (p. 407) states that he "failed to discover a single instance of the use, among the Georgia Indians, in ancient times, of the genuine red pipestone or catlinite." This pipe is $3 \frac{3}{4}$ in. in length, fairly well polished, with the two sides faintly and crudely etched, and with a cross scratched in the base. The bowl is not smoke-stained, nor does it show any marks of tooling; the opening of the mouthpiece, however, retains the round markings caused probably by turning the stem in the socket. The serrated end of the body suggests the tail of a conventionalized bird. A hole has been drilled from both sides, midway of the body, evidently to afford means of suspension by a thong on which had been strung certain Marginella shell and glass beads, found in direct association, as before described (pp. 39-40).

Lieutenant Timberlake ${ }^{1}$ speaks of a Cherokee calumet of catlinite in the eighteenth century as follows:

"During the dance, the peace-pipe was prepared; the bowl of it was of red stone, curiously cut with a knife, it being very soft, tho' extremely pretty when polished. Some of these are of black stone, and some of

1 Memoirs, p. 39, London, 1765 . 
the same earth they made their pots with, but beautifully diversified. The stem is about three feet long, finely adorned with porcupine quills, dyed feathers, deers hair, and such-like gaudy trifles."

In point of finish the finest stone pipe from Nacoochee is of steatite and was found by Captain Nichols prior to 1873 in the field near the western base of the mound. This pipe (pl. L, b) is delicately wrought, the walls of the bowl being only about a thirtysecond of an inch in thickness. It is highly polished, having much the appearance of glazed pottery. As in the case of the earthenware pipes generally, this one also has a flange at the end of the mouth-piece. Following the outer curve, the bowl measures nearly $1 \frac{1}{2}$ in. from the rim to the heel. This pipe, which was procured from Mrs George F. Payne, of Atlanta, is figured by Jones and also by McGuire, ${ }^{1}$ but neither illustration gives an adequate impression of the excellence of its workmanship. There are two other dark steatite pipes in the collection ( $\mathrm{pl} . \mathrm{L}, a, c$ ), of approximately the same form, but heavier and of less careful finish. One of these has a very narrow lip, and the sides of the mouthpiece are slightly squared. The flange seems to have been broken off, only the edge remaining to show that the fractured end had been rubbed down to fit the pipe for further use. Both of these pipes were found in the refuse of the mound.

Another excellent pipe, of greenish-gray steatite, is shown in pl. XLIX, $b$. It measures $4 \frac{1}{4}$ in. from mouthpiece to heel, the total length being 5 inches. This pipe was found with Burial 4 (pl. $\mathrm{xv}, a)$.

Rather crude in manufacture, jar-shaped, with heavy walls, is the gray steatite pipe illustrated in pl. XLIX, e. Like the fine little pipe of similar material, this specimen also belonged to the Payne collection, but it is not positively known to have come from the Nacoochee mound, although another of the same general form, but of hard stone, was found by us at the site.

Still another steatite pipe, with somewhat flaring sides, outcurving rim, and rather heavy walls, resembles some of the pottery forms. Its stem is broken off.

${ }^{1}$ C. C. Jones, Antiquities of the Southern Indians, pp. 4I0-4II, pl. xxIv, New York, I873. J. D. McGuire, Pipes and Smoking Customs, op. cit., p. 455, fig. 79, Washington, I899. 


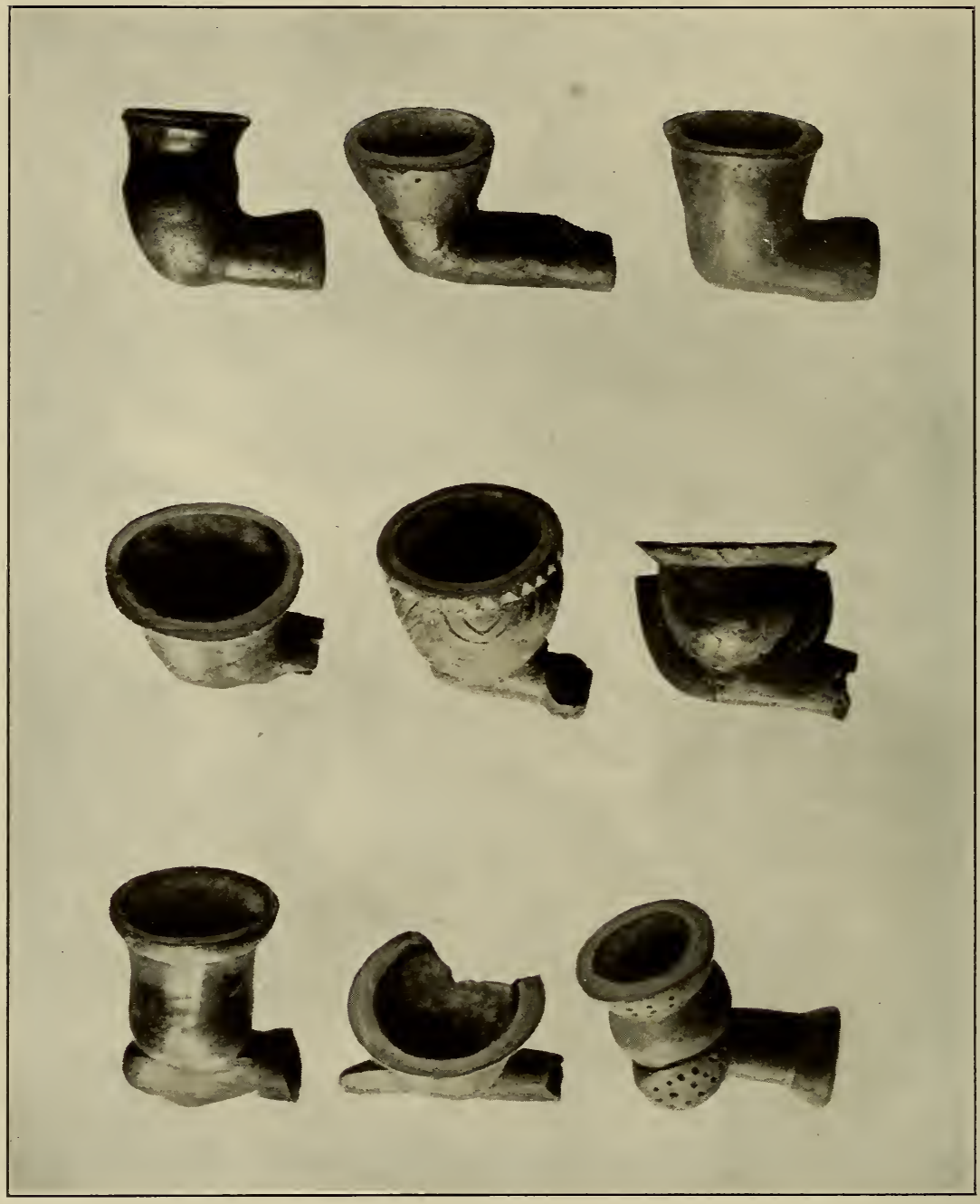

EARTHENWARE SMOKING PIPES 
The brownish pipe of the same material represented in $\mathrm{pl} . \mathrm{L}, e$, is rather interesting by reason of the unusual angle formed by the bowl and the stem.

Interesting on account of its form, which is that of the claw of a bear or other animal, is the schistose pipe shown in pl. XLIX, $d$. Its bowl is very small, and the entire finish, excepting that of the convex surface of the front, is rather rough.

Exceptionally crude is what is probably an unfinished pipe of porous ferruginous granitic stone, almost of the consistency of

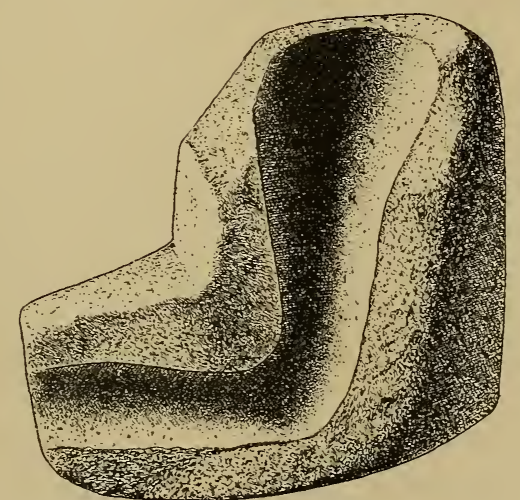

FIG. 53.-Part of a pipe of coarse sandstone.

coarse pottery, and stemless. The inside of the bowl and of the stem opening is smooth-finished, but the exterior is so rough as to suggest the primary stage of manufacture. Possibly the development of a crack extending halfway round the pipe was the reason for its rejection. It exhibits no smoke-blackening.

Part of another rude pipe (fig. 53) is of coarse red sandstone, broken almost through its center in such manner as to expose the entire interior. Smoke-blackening indicates that it had been used.

Possibly the cylindrical steatite object shown in pl. L, $d$, one and nine-sixteenths of an inch in length, and drilled or otherwise worked in one end to a depth of seven-sixteenths of an inch, may have been designed for use as a pipe bowl, although this is not certain.

The parts of two stems illustrated in $f, g$, of the same plate are 
of interest as showing that stone pipes had been provided with means of suspension-an uncommon feature of Nacoochee stone

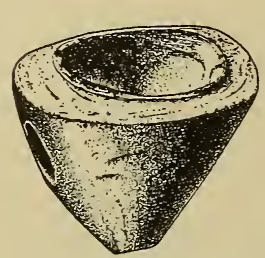

FIG. 54.-Part of a pipe bowl severed by cutting. pipes so far as our collections show.

The basal end of a pipe of a compact brownish stone, cut from the rest of the bowl for some unknown reason, is shown in fig. 54 .

\section{Objects of Stone}

Discoidal Stones.- Of all the objects of stone found at Nacoochee, the most numerous are certain discs or discoidal stones, fashioned usually from any water-worn or weathered stones, shaped by pecking or by rubbing, or by employing both of these processes. In most cases the rounding-out process by pecking or battering the edge was done rather roughly; in others the stone was further rounded either by modifying the natural pebble by slight rubbing on the prominent edges, or by rubbing the edges of the flattish stone that already had been more or less rounded by pecking or battering. Discoids of this type are of great variety of size and finish, their diameter ranging from a fraction of an inch to $4 \frac{1}{2}$ in. They were found throughout the mound, usually in the refuse, but in a few cases associated with burials. Their function is not certain, nor is it known that the large and the small were used for a similar purpose; but from the crudeness of some of them, and their general resemblance in size and form to the pottery discs already described, it is not improbable that they likewise were employed in gaming. Indeed, from the softness of the stone of which most of these discoids are made, and the fact that they bear no sign of use as tools, it is likely that they were employed in games rather than for more practical purposes. A selection of these discoids is shown in pl. LI.

The discoidal stones of this class to which the natives gave most attention merge into another and less common form, made usually of a dioritic stone, carefully fashioned and polished. These vary similarly in size and form, some of them being of equal diameter on both faces, others having slightly or considerably beveled sides, and all having more or less rounded edges (pl. LII). A specimen of this type, of fine-grained granitic rock, was found with Burial I. 



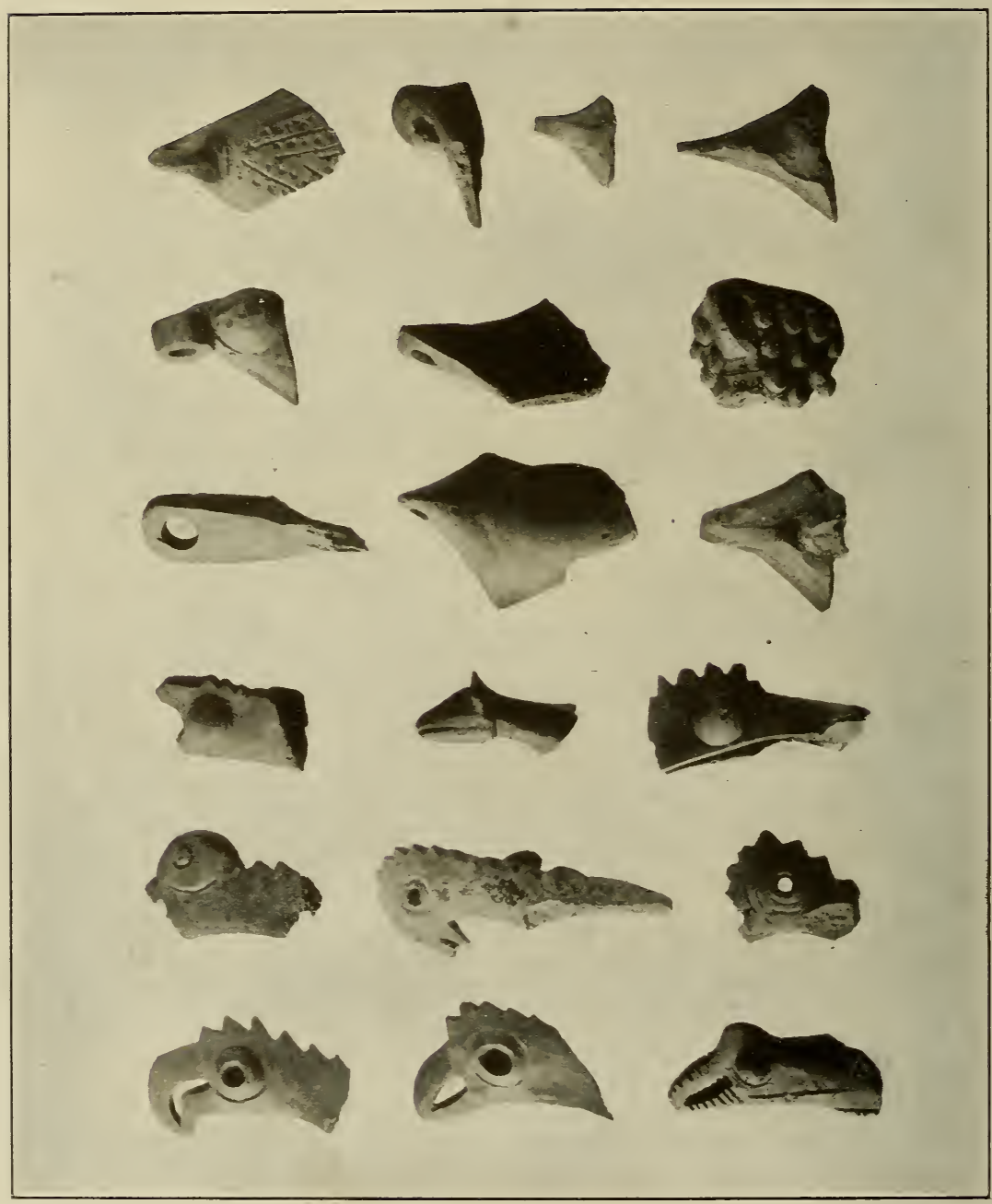

PARTS OF EARTHENWARE PIPE RIMS SHOWING ORNAMENTATION 
. 


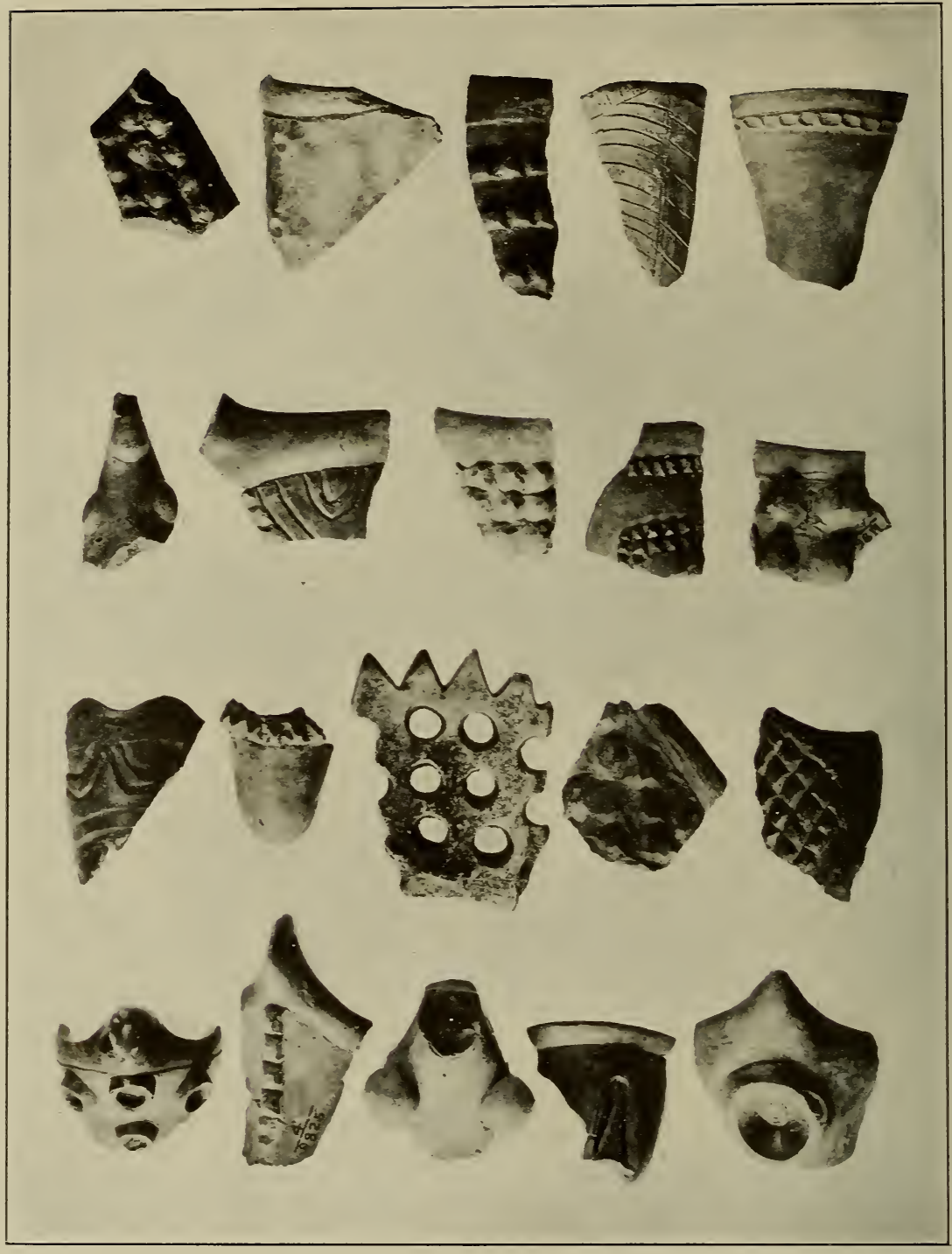

PARTS OF EARTHENWARE PIPE RIMS SHOWING ORNAMENTATION 
Still another class, closely approaching the last in form, but made of quartz, includes one specimen almost semiglobular in shape, while two others are identical in form with some of the dioritic discoids, but are of calcareous stone and seem to have been subjected to fire. Examples of this class are illustrated in pl. LIII.

It is difficult to reach any conclusion other than that the discoids flattened on one side and rounded on the other, if not those with both faces more or less flattened, were used in playing the chunkey game, as described by Timberlake, who from personal observation among the Cherokee in $\mathrm{I} 76 \mathrm{I}$, wrote:

"The greater part resolved to amuse themselves at a game they call nettecawaw; which I can give no other description of, than that each player having a pole about ten feet long, with several marks or dimensions, one of them bowls a round stone, with one flat side, and the other convex, on which the players all dart their poles after it, and the nearest counts according to the vicinity of the bowl to the marks on his pole." 1

Some of the discoids of the class first described are of steatite, in no case so well finished as the adaptability of this material to the shaping processes would have made possible. A few of the steatite discoids are pitted, and in addition to the pitting two of the specimens have rudely incised lines radiating from the center, while one of them has also faint, shorter intervening lines (pl. LIV, $e$ ). This crude attempt at ornamentation was not confined to the steatite discoids, however, as a small one of porous ferruginous granitic stone, tufa-like in appearance, bears similar diametric markings (pl. LIV, $a$ ).

Other pitted stones are small (averaging $\mathrm{I} / 2$ to $\mathrm{I} 3 / 4$ in.), clumsily made (pl. LIV $d, \mathrm{LV}, g$ ), and with a single exception are of sandstone or a granitic stone, the exceptional example being dioritic (pl. LII, c). In only one specimen of these objects is the pitting in one side only.

Of similar material and approximate size are perforated discoids (pl. LIV), some of them also grooved on the face, and one example having been perforated after breakage $(c)$, care not being taken to

${ }^{1}$ Henry Timberlake, Memoirs, p. 77 , London, 1765 . 
drill the hole centrally. The rude pendant-like specimen of this type $(i)$ is of steatite, as also is the much better finished annular stone $(g)$, on the faces of which ornamentation has been attempted by scratching.

Another class of pitted stones, evidently bearing no relation to those described, will be referred to later.

Abrading Stones. - The abrading or rubbing stones are not very numerous, nor do they offer any unusual types. They range from natural pebbles of soft sandstone, similar to some of the discoids (the edges worn by abrasion with other objects and the surfaces in a few cases being irregularly scored as if in pointing implements), to more or less irregular water-worn stones on which no workmanship had been expended in order to adapt them to the purpose for which they were designed. One fragment, judging by the stains on its only smooth face, was used for grinding hematite.

A rather interesting stone of this class, measuring in by 8 by $4 \frac{1}{2}$ in., has a shallow groove, three-quarters of an inch wide, extending from one end of its smoothest face to the other, as if used in rounding or smoothing the edges of such objects as the smaller discoids above described, or for smoothing or pointing the ends of wooden objects.

Pottery Polishers.-Numerous small unworked pebbles, chiefly of quartz, were found throughout the mound, and two were associated with Burial 2, together with two diminutive stone discoids. These stones are of the class used for rubbing pottery before firing; they differ in no wise from the pottery-polishers so common at archeological sites wherever earthenware has been made, and which are still in almost daily use by our Pueblo Indians at the present time. What may have served, at least secondarily, as a pottery polisher, is a small spherical object of steatite (pl. Lv, i), which will be mentioned later in referring to specimens made of that material. A small, dark, slate-like, triangular stone, an inch in length, thick at one edge but beveled at the other, may well have served the purpose of indenting some of the ornamental motives on the rims of certain pottery vessels.

Celts.-Considering the amount of exploratory work done at 



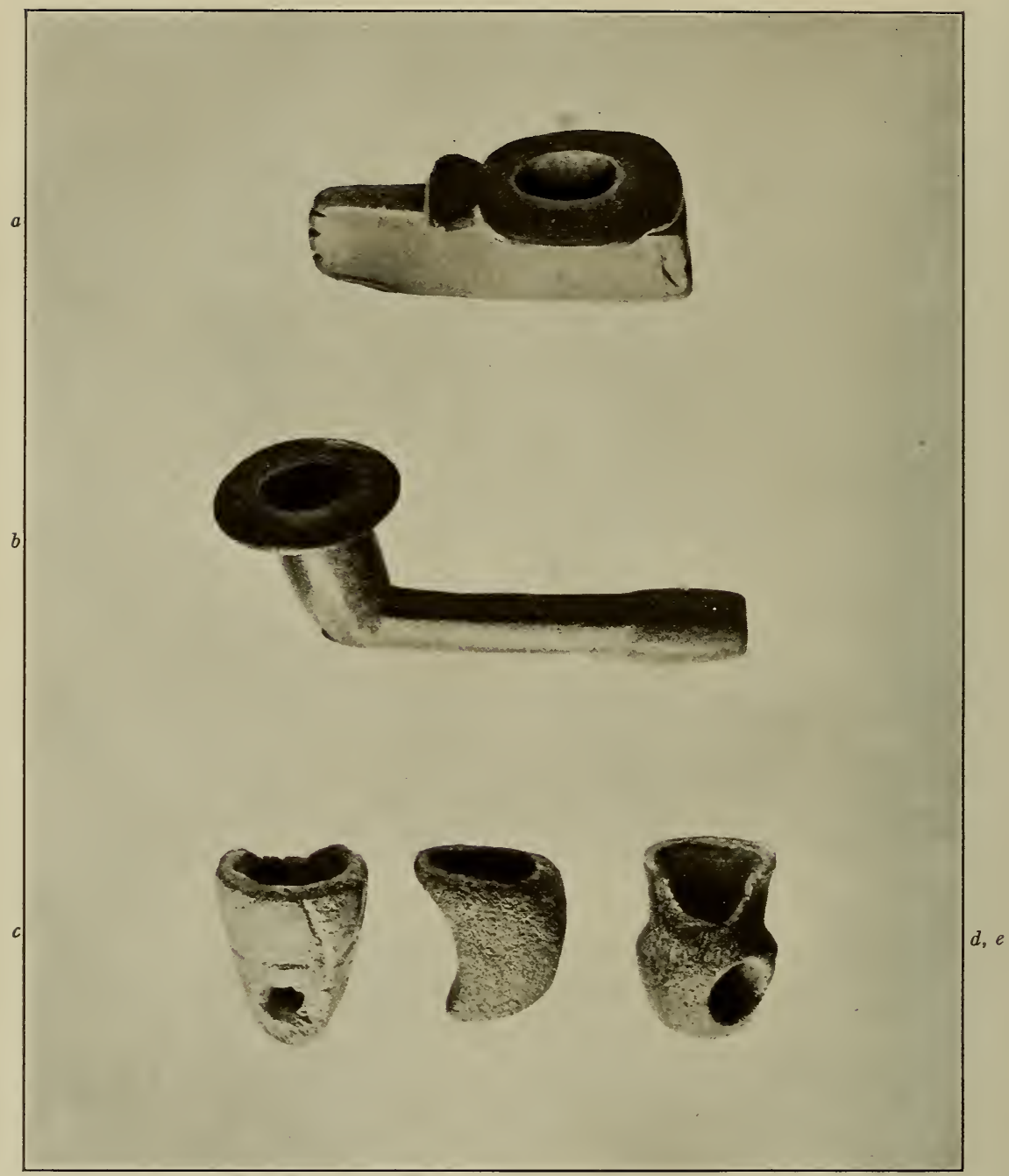

SMOKING PIPES OF STONE 
Nacoochee, the stone celts ${ }^{1}$ recovered (all but one of which had been deposited with the dead) are not numerous, and in this respect are not at all in keeping with the highly-finished discoids, for example, which the mound produced. But what the ten celts lack in number is met by the excellence of the workmanship (pl. LV, LVI). All are either of hard, compact stone, of the dioritic or granitic kind from which most of the highly finished discoids are fashioned, or of slate, and all but one (pl. LV, $e$ ) are perfect or nearly perfect in condition. Three are almost or quite flat and round or elliptical in section at the poll, and the poll of the small damaged celt was probably of like form; two are only slightly rounded, and likewise are elliptical in section; the poll in three is flattish and elongate, while that of another, battered shapeless by use of the celt as a hammer, was probably also of this form. The smallest celt measures 4 in. in length in its broken condition, $\mathrm{I} 3 / 4 \mathrm{in}$. in width at the blade end, and $\mathrm{I}$ in. in maximum thickness; the next largest, flat, thin, and chisel-like (pl. LVI, $e$ ), and perforated near the poll, is $63 / 4$ by $23 / 8$ by $5 / 8$ in. in corresponding dimensions; the largest celt measures $81 / 4$ by $3 \frac{1 / 4}{4}$ by $13 / 4$ in., while two others are only slightly smaller, if not so heavy. Four of the celts, including the perforated specimen as well as the largest one of the series, were found with Burial 53 ; others were associated with Burials 22, 56, 59, 60, and 63, while one, it may be recalled, was found apart from a burial. The perforated celt referred to possesses an interesting feature in that it shows a whitened band, nearly $\mathrm{I} 1 / 2$ in. wide and slightly diagonal, commencing just below the perforation, marking the former attachment of a handle; and another implement of this kind (pl. LVI, $f$ ) is similarly marked by slightly oblique lines of abrasion from the edges of the handle, as referred to in describing the copper celts.

Regarding the limited number of the celts, it should be borne in mind that, Nacoochee having been occupied far into the historical period, its inhabitants must have employed tools and implements of civilization long before the abandonment of the site, consequently tools of stone doubtless had been superseded by those of metal many years before. On the other hand, while fragments of celts

1 See footnote, page 23 . 
and chisel-like implements were found, they were not sufficient in number to account for the fact that apparently at no time in the history of Nacoochee were many stone implements in use. It should also be noted that most of the celts were unearthed at considerable depth. A few fragments of small celts of fine-grained, granitic stone were found in the mound débris, but these afford no additional information. Not a single grooved axe was recovered; but an axe of this kind, found in one of the stone graves opened by Captain Nichols, is now in the Museum of the American Indian, Heye Foundation.

Among the chisel-like objects not described above are the wellfinished and perforated specimen shown in plate LV, $d$, as well as a number more or less fragmentary, all small in size, and for the greater part thin and delicately finished. Among these fragments are represented three chisels, one edged at both ends, perfect except at the narrower end, measuring $31 / 2 \mathrm{in}$. long, $\mathrm{I}$ in. wide at the wider blade-end, and seven-sixteenths of an inch thick at the middle. The stone is very hard and compact, apparently granitic, and dark brown in color. The other broken implements of this type are not sufficiently complete to afford any interesting feature, save one of dark-greenish stone which has been used slightly for rubbing or polishing at the broken poll end.

A small chisel of hard, yellowish sandstone, complete, measuring $3^{11} / 16$ in. long and five-sixteenths of an inch in width as well as in maximum thickness, is of natural formation ground to an edge at one end ( $\mathrm{pl}$. Lv, $f$ ). Another small chisel or celt, apparently of schist, 3 by $\mathrm{I} 3 / 4$ by $3 / 8$ in., showing slight sharpening at the broader end, is also of natural form; both ends are broken, the broader end so fractured as to carry away the edge opposite the sharpened edge mentioned.

Still another celt-like object (pl. LV, c), of dark-gray granitic stone, has a broken but formerly sharpened edge at the narrower end. The opposite edge has evidently been grooved on each side and then broken off. The longer edges of the implement have been beveled, probably through abrasion during use as a rubbing stone, thus suggesting its application to many uses. 


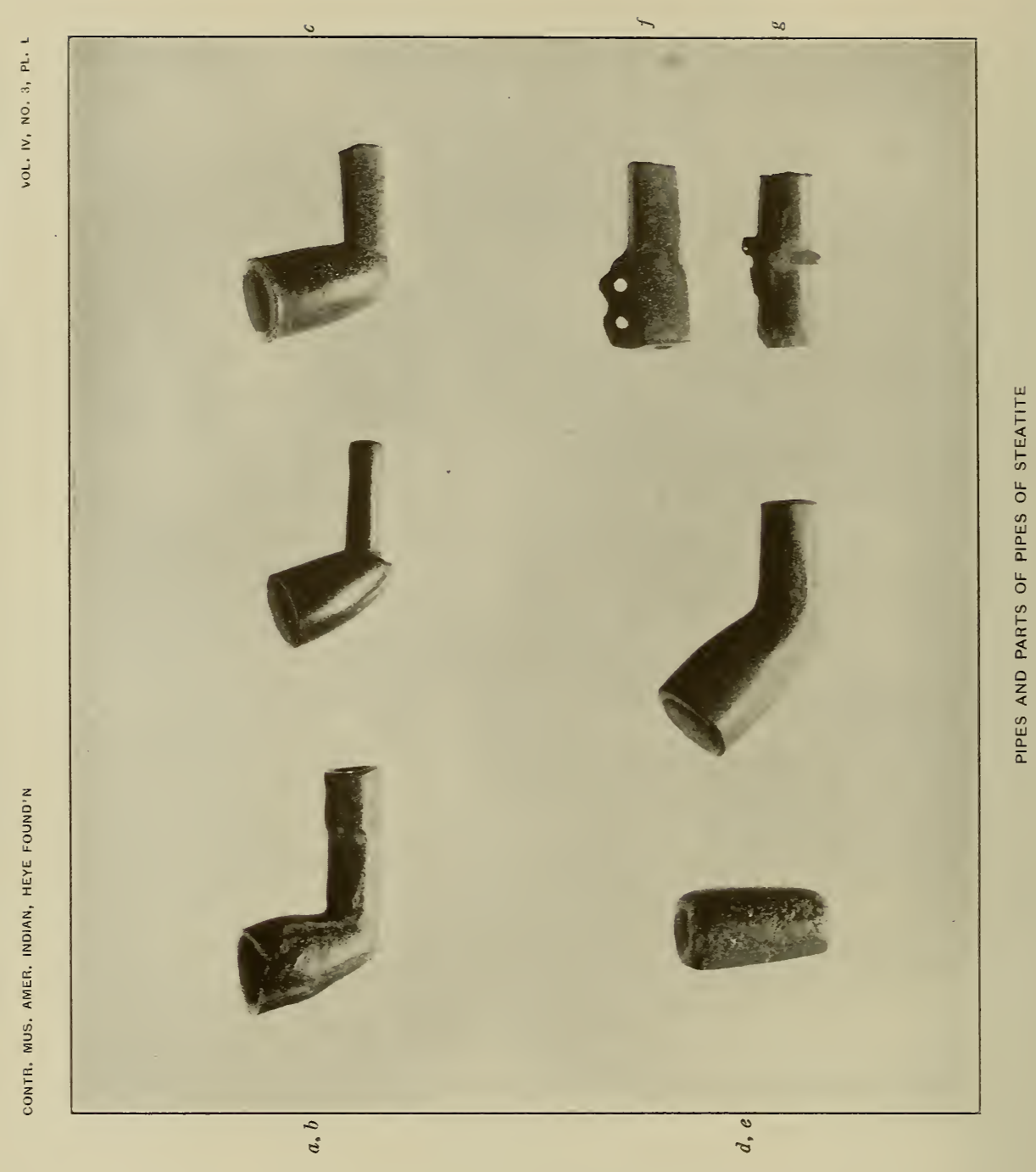


Steatite Objects.-Deposits of steatite are found in adjacent mountains, and although the inhabitants of Nacoochee made use of them, comparatively few objects of this adaptable material were found. We have already mentioned the rude annular and discoidal objects of soapstone, as well as the utilization of this material in the manufacture of pipes.

Two small fragments of large steatite vessels were found in the mound débris; likewise half of a diminutive vessel which, when complete, measured about $3 \frac{1}{2}$ in. in diameter and $15 / 8$ in. in height, and a portion of a crude annular object only slightly smaller in dimensions. More interesting is a coarse micaceous steatite object of unknown use, of the so-called "plummet" variety, 4 in. in length, $\mathrm{I} 1 / 2$ in. in maximum diameter at the middle, tapering to three-fourths and seven-eighths of an inch respectively at the ends, around one of which, half an inch below, a shallow and narrow groove has been cut as if to provide means of attachment (pl. LV, $b$ ). A similar object, $2^{1 / 16} \mathrm{in}$. long and three-quarters of an inch thick, was in the Payne collection, and if it did not come from Nacoochee, it is certainly from that vicinity. Its flat base has a shallow depression and its top is knobbed. Another, more like the first one described, is illustrated by Jones and mentioned as possibly "employed to weight the hand-line in fishing with a hook." 1 Still another object, of indurated soapstone like one of the fragments of vessels above described, is roughly spherical in form, I to $\mathrm{I} 1 / 2$ in. in diameter, at one end of which a small boss or knob has been cut (pl. LV, i). From the fact that the under face of this object is smoothly worn, it may have been used in polishing pottery. It was found with Burial 2.

A steatite bead is mentioned on page 87 , and reference has been made (p. I7) to the finding of a steatite ear-plug in a Nacoochee stone grave by Captain Nichols.

Considering the availability as well as the adaptability of the raw material, therefore, there was an unexpected paucity of steatite objects in the mound.

Pitted Stones.-Classed generally as pitted stones, or those which

\footnotetext{
${ }^{1}$ Jones, op. cit., p. 399, pl. Xıx, 12 .
} 
bear depressions in one or both faces, there are numerous objects in addition to the pitted steatite discoids previously described. These range from fairly large, roughly-fashioned mortars (almost too shallow to justify the name, however), to pebbles or bowlders sufficiently small to be held conveniently for pecking, pounding, and the like, the pitting having been designed to facilitate grasping. The materials range from hard, compact stone to soft sandstone.

The large mortars, if we may so designate them, measure roughly Io by Io by 6 in. and I I by 6 by $5 \frac{1}{4}$ in. respectively in greatest dimensions, while the depression in each is only about $\mathrm{I}$ in. in depth and 5 in. in diameter. The stone of which each is made is very irregular, no shaping having been done in order to make it symmetrical; indeed it would seem that the first field stone at hand in each case was adapted to the purpose intended. An exceptional mortar, a mere toy in size ( $\mathrm{pl} . \mathrm{LV}, \mathrm{g}$ ), has a depression only large enough to receive the tip of the forefinger. This specimen recalls the tiny crude earthenware receptacles made by or for children.

Most of the pitted stones, and especially those with depressions in both sides, were used as hammers, as is shown by the convenient manner in which the pitting fits the thumb and forefinger, and by the presence of at least one battered end. A few examples of pitted stones, however, are of soft material, such as ferruginous sandstone, mica schist, etc., hence they could not well have served as hammers or pounders; and still other examples are pitted so slightly that their intended function is not apparent, although some of these come within the class sometimes, for want of a better name, are called "nut-crackers." A small discoid of greenish stone, measuring only seven-eighths of an inch in diameter by fivesixteenths of an inch in thickness, the edge slightly beveled, is pitted in one face (pl. LII, $c$ ).

Hammerstones not pitted were found in considerable number, and are of several forms, depending on the shape of the pebble or bowlder, or on the use to which it was to be put. The simplest of these, of course, is the hard, more or less rounded, water-worn stone, not modified for the purpose of improving the shape, and battered usually at one end only. Others merge into the discoids, 


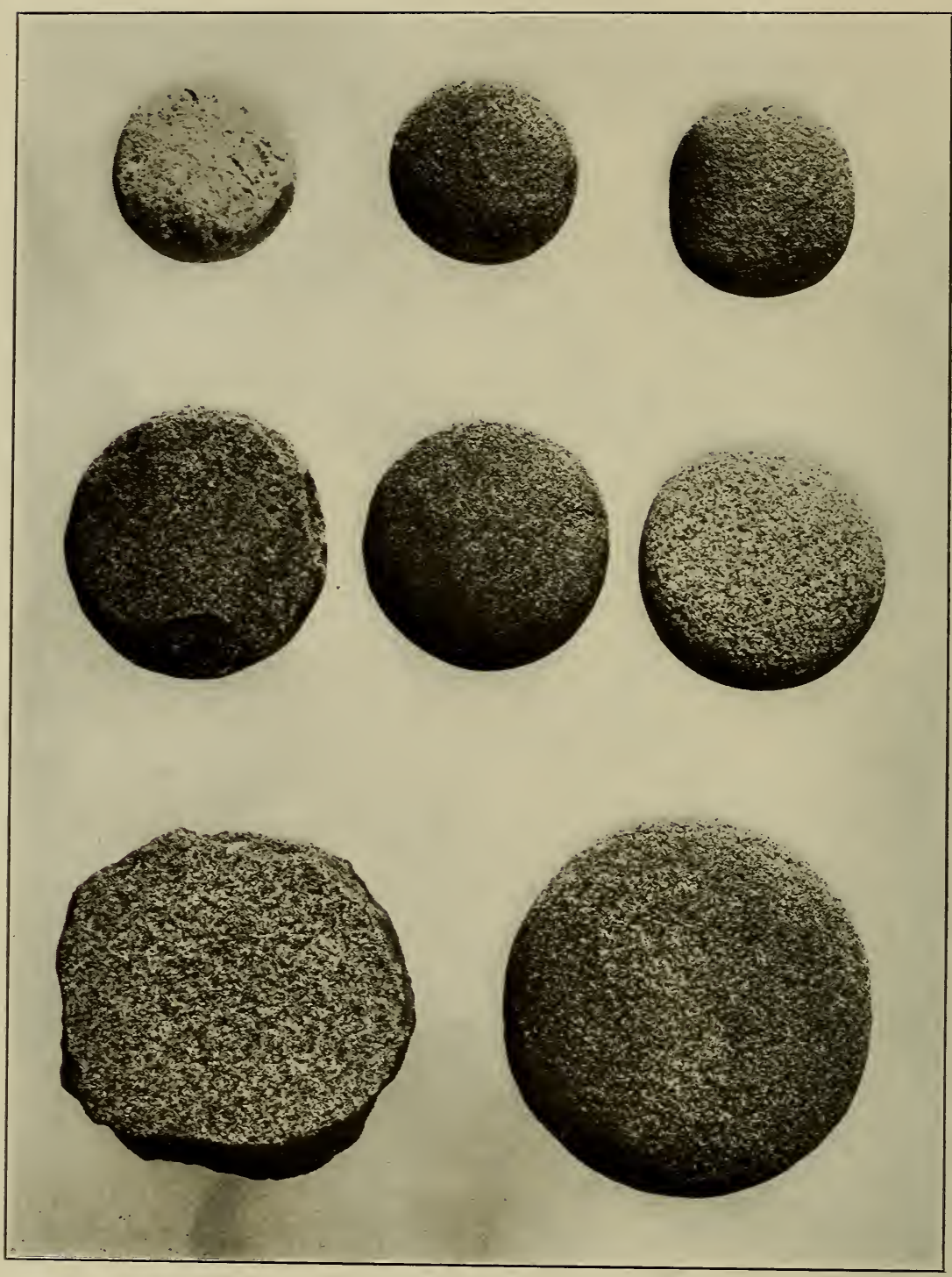

DISCOIDAL STONES PROBABLY USED IN GAMING 
and indeed there are indications that some of the hammerstones were primarily designed for use as discs but were spoiled in the process of manufacture. There are no hammerstones of unusual form from Nacoochee, all partaking of the character of those common to archeological sites generally.

Net-sinkers.-Various flat stones, deeply or shallowly notched in one or both sides, and of the form usually called net-sinkers, were found in considerable numbers among the refuse (pl. LVII). These vary in size from 2 in. in width by $3 \frac{1}{2}$ in. in length, to $3 \frac{1}{2}$ and 5 in. for the same dimensions, and there were others, represented by fragments, even larger. Sometimes the notch is relatively deep and smooth, in other specimens there is little more than a suggestion of notching. Lack of indication of battering of the edges by use against other stones shows that these objects were not designed as stone-working tools, but served some such purpose as that of sinking fish-nets in streams. Indeed the stone of which they are usually made is too soft to have withstood hard usage, although a few specimens, of harder stone, may have been rejected hammerstones subsequently notched for use as sinkers. The largest specimen of this general type, $61 / 2$ and 8 in. in medial diameters, is well battered at the narrower end, indicating its use as a hammerstone.

Ornaments.-Little in the way of stone ornaments was found at Nacoochee, even the burials being practically devoid of accompaniments of this kind, evidently because shell was more highly regarded for objects of personal adornment.

A crude object of laminated shale, shaped in the form of an arrowpoint by rubbing, but in no wise sharpened, may possibly have been used as an ornament, and a fragment of what appears to have been one of the wings of a bannerstone, or "butterfly gorget," found apart from burials, is the only object of this form unearthed.

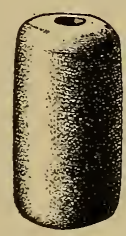

Fig. 55.Steatite bead.

Stone beads are entirely absent, excepting one of dark steatite thirteen-sixteenths of an inch in maximum length, tubular with slightly rounded ends, and neatly drilled from one end only (fig. 55). Jones (p. 235, pl. vi) mentions and illustrates a large stone bead as 
among the accompaniments of one of the stone graves opened by Captain Nichols.

A tiny object, seemingly of ferruginous sandstone, only an inch by three-quarters of an inch in length and width (pl. $\mathrm{LV}, h$ ), having much the appearance of a miniature grooved hammerstone, may have been used for ornamental purposes, or possibly as a toy.

Chipped Stone Implements.-Two lanceolate blades (pl. Lv, $a$; LVI, b) were found in graves, the smaller with Burial I3, the other with Burial I4. The latter specimen, of grayish slate mottled with quartz-like nodules, is $81 / 4$ in. in length by 2 in. in maximum width; it is nicely chipped, thin, with finely serrated edges, and perfect in condition. The smaller, of bluish gray flint or chert, is only half as long; it is likewise relatively thicker owing to the presence of refractory humps in the stone that evidently could not well be removed without risk of breaking the blade. One of the points is missing.

The remaining chipped stone objects found at Nacoocheeknives or spearpoints, arrowpoints, etc., offer nothing new in form or character. The best of the arrowpoints are of chert or flint; they are elongate as a rule, with rather prominent central ridges on one or both faces, and are without barbs, but often the base is made concave to receive the end of the shaft. A few examples are nicely chipped, symmetrical in form, and thin in section. In length, they range from three-quarters of an inch to an inch and five-eighths. A few of the arrows are of quartz, jasper, and chalcedony; of these the last mentioned are generally thinner and more skilfully chipped than those made of other stone. Most of the arrows were found apart from graves. With Burial 46, however, there were 45 of these projectiles, chiefly of flint or chert, and with Burial 59 there were three others.

The chipped stone objects of the knife variety, distinguished from the arrowpoints chiefly by their size, are of quartz in the main, and usually are clumsily made, some of them having irregularly chipped facets and prominent ridges. Sometimes the base is concave, as in the case of the arrowpoints, but, unlike the latter, some are nocked for facility in mounting. 


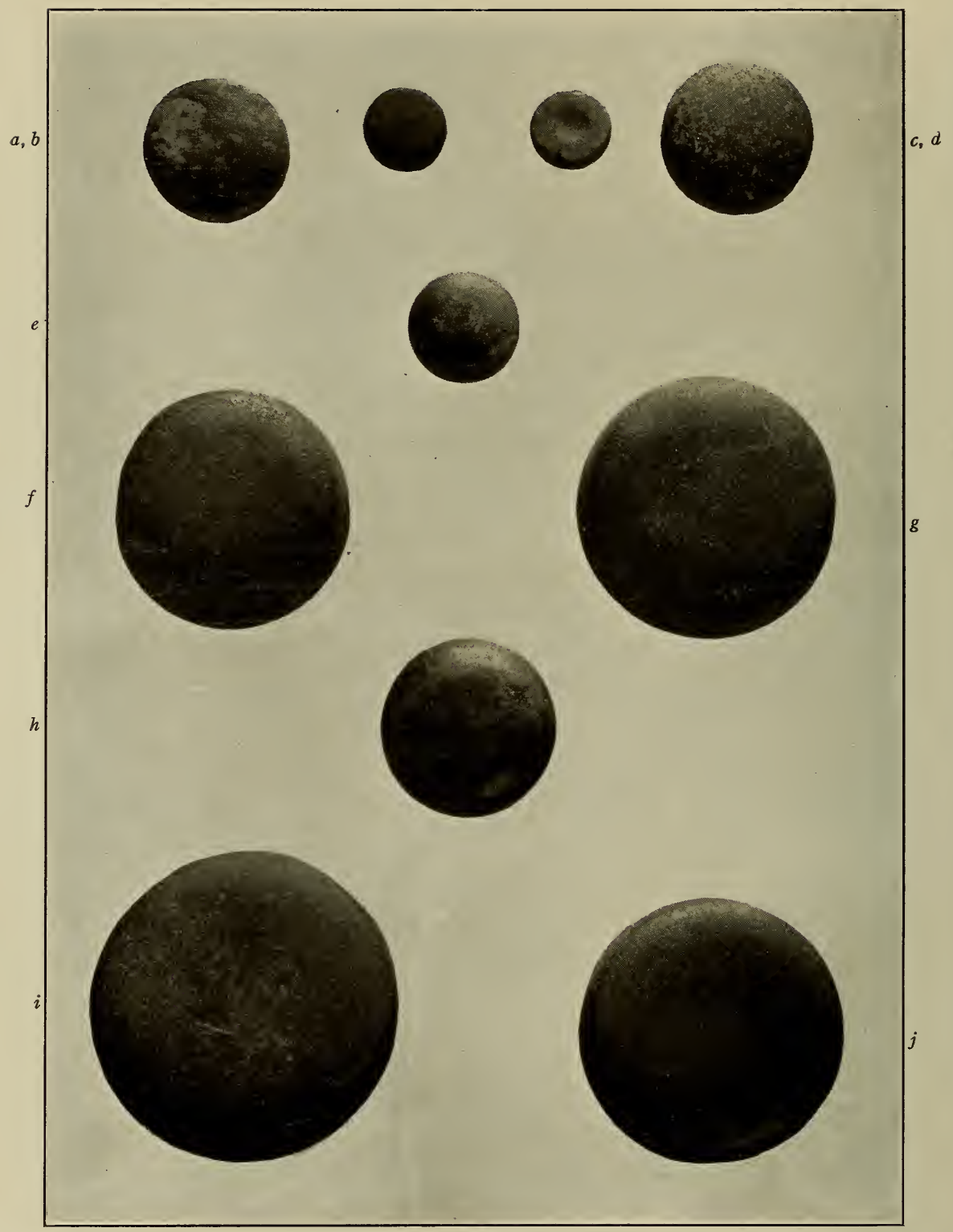

HIGHLY FINISHED DISCOIDAL STONES 
Altogether these implements, if we except the excellent lanceolate blades above mentioned, do not display great skill in stonechipping on the part of the natives of Nacoochee.

A few gun-flints were unearthed in the upper part of the mound, within four feet of the surface.

\section{ObJects of Shell}

As already noted in describing Burials 39 and 74 , it was the custom of the natives of Nacoochee, as well as of other Southern sites, to remove the columellæ of certain conchs for the purpose of transforming them into drinking-cups, and indeed Jones ${ }^{1}$ has mentioned that "in the stone graves of Nacoochee valley more than one Cassis flammea was seen. In each instance the interior whorls and columellas had been carefully cut away, so that these large univalves formed capacious and serviceable vessels." Parts of similar cups, as well as columellæ of shells from which they had been fashioned, were found also in the refuse, and a columella was associated with Burial I4. But unfortunately shell objects of all kinds had become greatly disintegrated, evidently on account of the decaying effect of the moist soil of the mound. Numerous beads and other ornaments were of such limy consistency as to be beyond recovery, while others, although preserved, have lost much of their former shape. Exceptions to this condition are found in a Unio (U. complatus Dillwyn) and in certain univalves (Polygyra albolabris (Say) and P. thyroides (Say)), many hundreds of which, especially the former, taken from the refuse, are in excellent condition, the Unios retaining their nacre as freshly as ever. A small Unio has been drilled near the hinge to afford a means of suspension, evidently as a pendant, while two others have been serrated at one end, possibly for use in decorating pottery. Hundreds of these bivalves are considerably abraded at the longer outer edge by use as implements; indeed some are so greatly worn as to be concave, instead of convex as in nature, and as shells of this kind would have made excellent pottery-finishing tools, they may have been employed for such purpose. Others, while also worn at the outer

1 Antiquities of the Southern Indians, pp. 233, 499, New York, I873. 
edge, retain their convexity, as would have been necessary if used for finishing the inner walls of earthenware vessels. It is possible also that some of these bivalves may have been used as spoons, although they are rather small for this purpose, and, moreorer, the worn edge is squared rather than sharp, which would not be the case if employed for any purpose other than deliberate scraping, such as the walls of pottery receptacles. Moreover, very few of the shells exhibit the effect of wear on the outer surface.

The Polygyra shells bear no evidence of use, although many hundreds were found in the refuse, especially in that under the southeastern slope of the mound. Certain sherds of earthenware, however, bear a uniform crescentic decoration of the rim, such as might have been produced by pressing the lip of such a shell in the moist clay, as observed by Mrs Heye while assisting in the work of excavation.

It was for personal adornment that shells were chiefly employed, most of the worked specimens, especially various forms of shell beads, being found in association with the remains of the dead, as mentioned in the description of Burials I, 2, 3, 5, 7, I3, 22, 33, 53 , and 70 .

Information respecting the use of shells by the Cherokee in the eighteenth century is afforded by Timberlake, ${ }^{1}$ who says, "They that can afford it wear a collar of wampum, which are beads cut out of clam shells." Adair ${ }^{2}$ gives further particulars regarding the use of beads and other shell ornaments by the Cherokee, as follows:

"The American Archi-magus wears a breast-plate, made of a white conch-shell, with two holes bored in the middle of it, through which he puts the ends of an otter-skin strap and fastens a buck-horn white button to the outside of each. ...

"The Indian nations are agreed in the custom of thus adorning themselves with beads of various sizes and colours; sometimes wrought in garters, sashes and necklaces, and in strings around their wrists; and so from the crown of their heads sometimes to the cartilege of their nose. And they doat on them so much as to make them their current money in all payments to this day.

1 Op. cit., p. 39.

2 Op. cit., pp. 84, I 70 . 



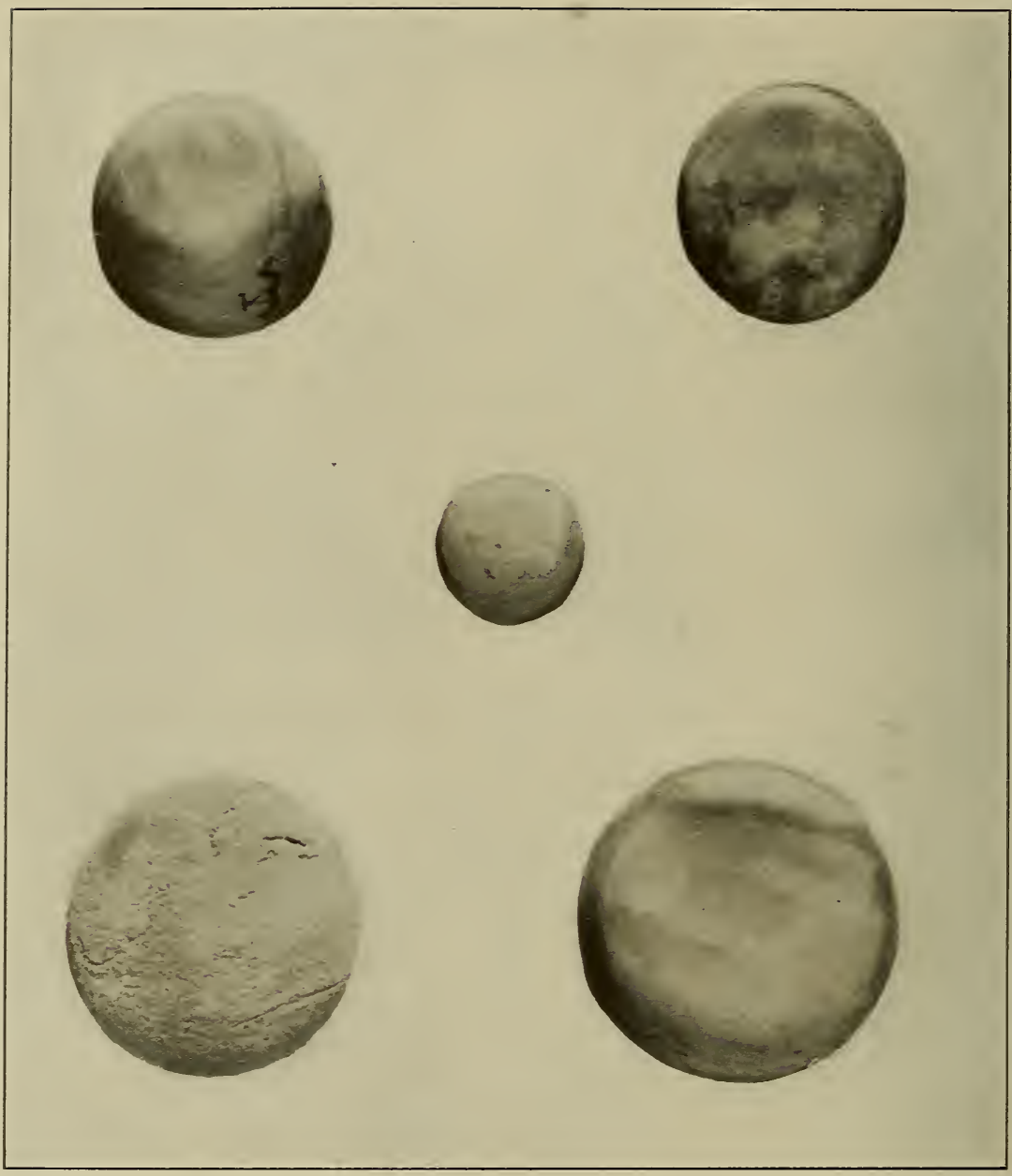

HIGHLY POLISHED DISCOIDS OF QUARTZ AND CALCAREOUS STONE 
"Before we supplied them with our European beads, they had great quantities of wampum; (the Buccinum of the ancients) made out of conch-shell, by rubbing them on hard stones, and so they formed them according to their liking. With these they bought and sold at a stated current rate, without the least variation for circumstances either of time or place; and now they will hear nothing patiently of loss or gain, or allow us to heighten the price of our goods, be our reasons ever so strong, or though the exigencies and changes of time may require it. Formerly, four deer-skins was the price of a large conch-shell bead, about the length and thickness of a man's forefinger; which they fixed to the crown of their head, as an high ornament-so greatly they valued them. Their beads bear a very near resemblance to ivory. . . ."

The shell beads worn by the inhabitants of Nacoochee are of several varieties, governed largely by the species of shells from which they were made. The largest ones were
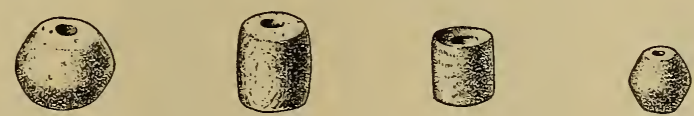
fashioned from the columellæ of conchs, more or less of the natural surface of the s he 11 being preserved. The large beads men-
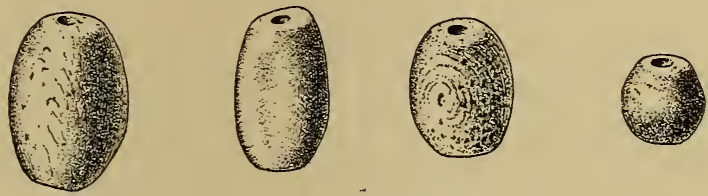

FIG. 56.-Various forms of shell beads. tioned in the description of Burial I as forming a breastplate are of this kind, the ornament having been fastened in some manner by means of a string of smaller beads of two sizes, probably also made from columellæ, but all are so greatly disintegrated that the original form of most of them is not determinable. A number of these smaller beads, however, are similar to many found with Burial 3 in association with trade beads of blue glass, the whole likewise

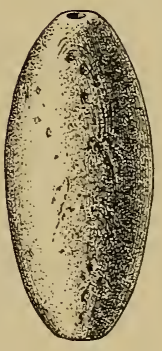
forming a breast ornament. Most of these latter shell beads are barrel-shaped, varying in size (the largest being half an inch long) as well as in thickness (the largest measuring seven-sixteenths of an 
inch), while some of the smallest ones are cylindrical, others almost spherical, and only three-sixteenths of an inch in length. The largest beads made from conchs were found with a celt in association with Burial 53, one of which is $21 \mathrm{~s}$ in. long by an inch in diameter, and all bearing very- little finish. as if it were the desire of the maker to preserve as much of the shell as possible. Those found

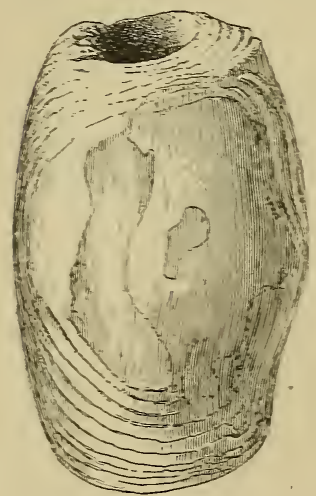

FIG. 5\%.-Beads made from the columella of the conch. with Burial 5. however, had been more or less symmetrically shaped. Examples of shell beads

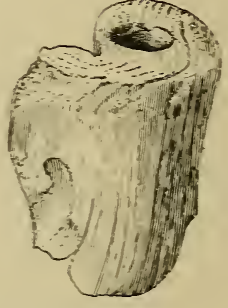
are shown in fig. $56-5 i$.

With Burial 2 were n u m e r o u s Marginella shells (M. conoidalis Kien), found on and under the scapulæ and pelvis, evidently having been fastened to the shirt and leggings by sewing through an aper-

ture made in the wall of the shell by grinding or rubbing rather than by drilling. As in the case of Burials 3 and 4 , these were accompanied with objects of European manufacture, including glass beads; indeed most of the shell beads were found in the upper part of the mound, within about four feet of the summit, which may not be significant if we account for the loss of others, deposited with the dead at greater depths, through complete decay.

Some of the shell beads found with skeletons are tiny and well made, a few of them indeed being so diminutive as barely to accommodate the drilling, being little more than a sixteenth of an inch in diameter.

In addition to the beads fashioned from conchs, large pendants or gorgets were made, as mentioned by -Adair, but as in the case of most shell objects, these were usually decayed beyond recorery. One of these, perforated at the center, was found with Burial I3. beneath one of the fine chipped blades before described. It was 



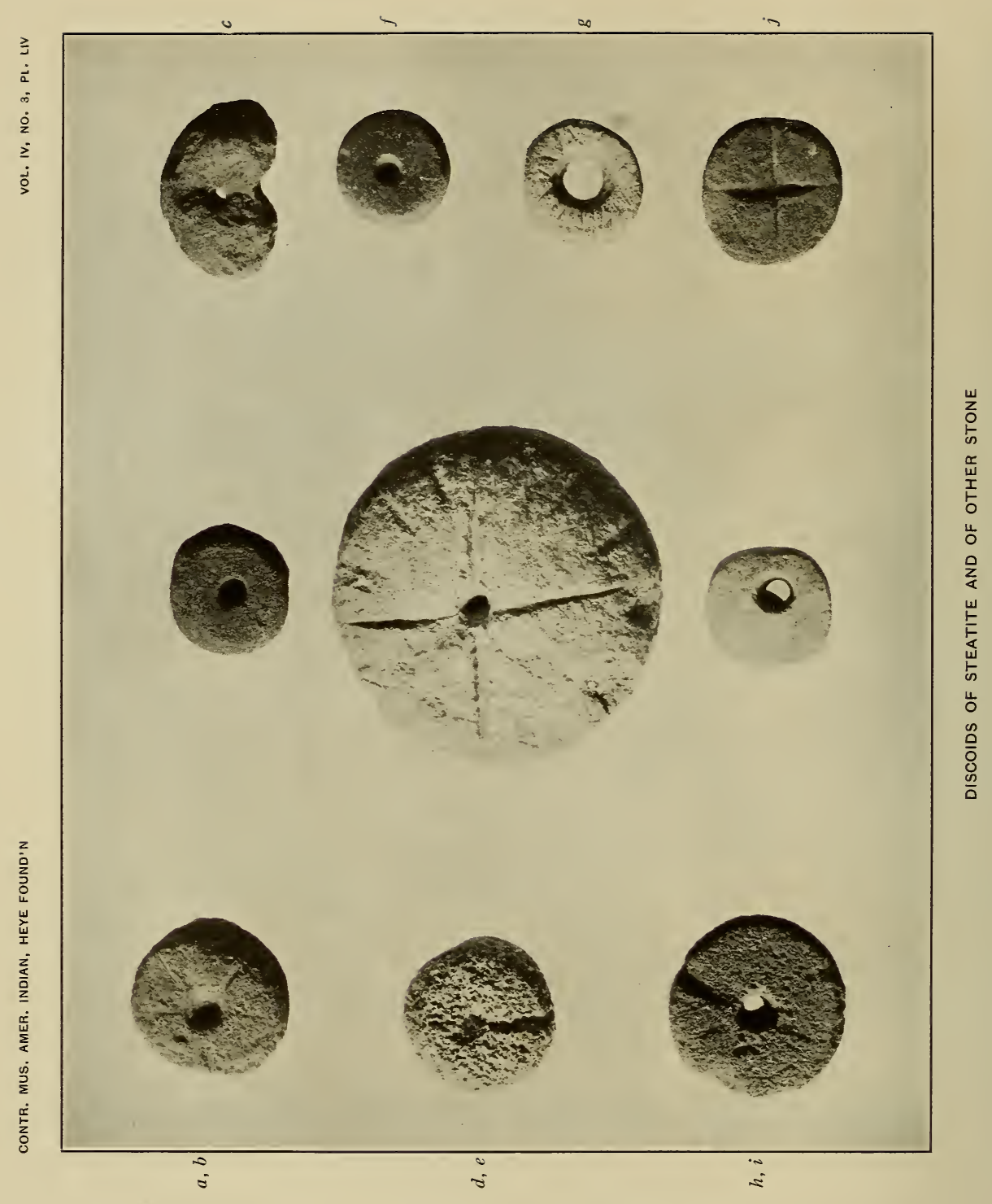


in fragments, but when entire was probably five inches or more in maximum diameter. The object fashioned from conch shown in fig. $5^{8}$ may have been intended for use as a pendant.

Finally, there were found with skeletons, in every case in connection with the skull, the remains of ear-plugs and hair ornaments evidently made from the conch. Enough of these objects remains to indicate that they were of two types-those with knobbed heads and those with flat heads, identical in form with some that have been found in Tennessee

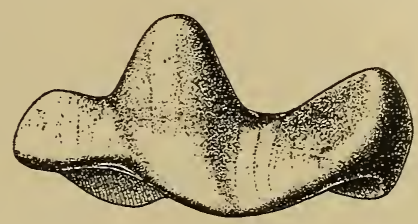

Fig. 58.-Object of shell probably designed for use as a pendant. mounds. It will be recalled that Jones (pp. 233-234, pl. vi) de-
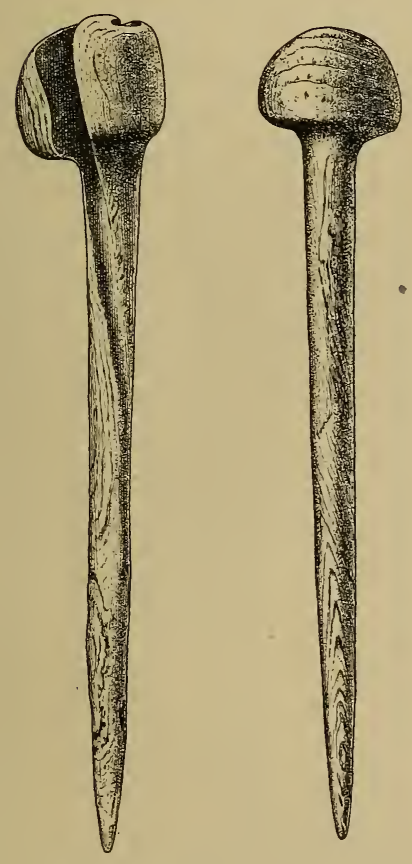

FIG. 59.-Ornaments of shell from the Soquee site.

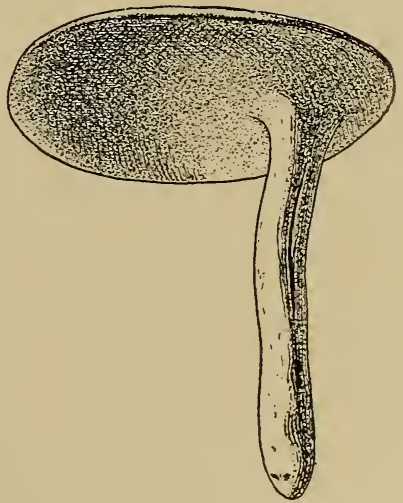

scribes and illustrates two "shell pins" found in one of the Nacoochee stone graves by Captain Nichols, one of which was of the 
knob-head form. We have already mentioned ear-plugs of pottery, probably designed for temporary use to enlarge the aperture in the freshly-pierced lobes, and Jones refers to and illustrates one of steatite of identical form, found also by Captain Nichols.

The disintegrated fragments of these shell ornaments found by us are practically worthless for illustration, but fortunately the Museum of the American Indian, Heye Foundation, possesses examples of all these forms of ear-plugs and hair ornaments from the Cherokee village-site of Soquee, only a few miles away. These are represented in fig. 59 .

We have mentioned the use of ground shell for tempering the clay used in the manufacture of pottery receptacles.

\section{Objects of Bone and Wood}

There is a decided paucity of bone objects from Nacoochee, owing chiefly to the fact that implements and ornaments were not made of bone in considerable quantity, if conclusion may be based on the number of such objects found. Mammals and birds were no doubt abundant in the neighboring mountains in early times, and indeed bones in numbers representing the fauna of the region were found during the course of the excavation, including those of the Virginia deer, black bear (both of which were very numerous), gray fox, squirrel, opossum, and wild turkey. ${ }^{1}$

Awls, as usual, are most prominent in the collection of bone objects. For the greater part, these were found with other refuse, having been cast away because of breakage. They are chiefly of deer bone, the articular process forming a convenient handle; but there are a few slender examples as well, all imperfect, made from animal ribs or from the bones of birds. None of them offers anything of particular interest, as all belong to well-known forms that have often been illustrated. A punch-like implement (fig. 60), $5 \frac{1}{4}$ inches in length, is exceptional in the collection.

The most interesting specimen made of bone is the pin shown in fig. $6 \mathrm{I}$; it is $37 / 8$ inches in entire length, the head being $\mathrm{I} 1 / 8$ inches

1 The determinations were courteously made by Dr Gerrit S. Miller of the United States National Museum. 
. 


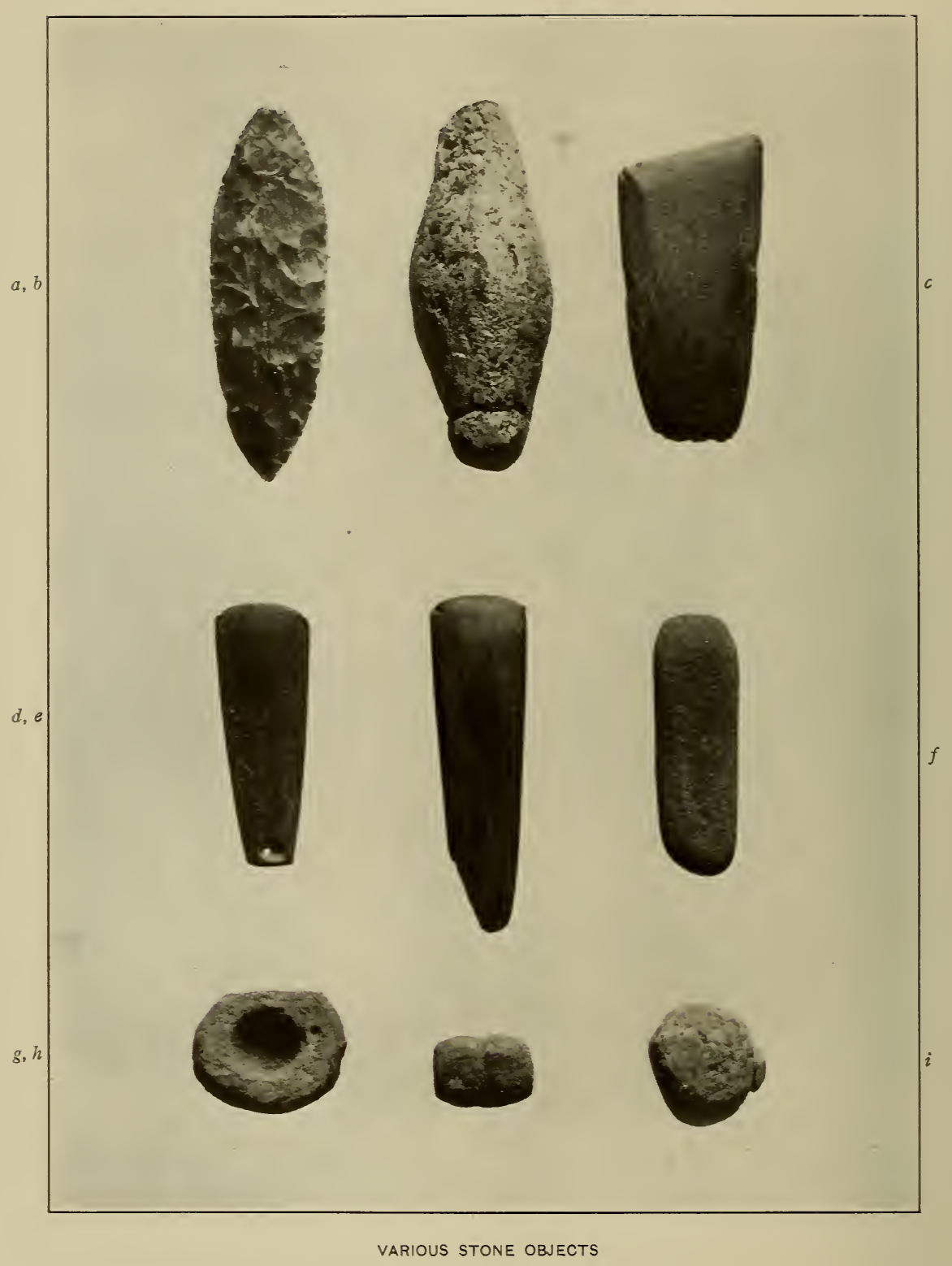


in diameter from left to right. This object was found with the skull of Burial 7o, exposed by the caving of the bank after a heavy rainfall.

Antler.-With the bones we may class the gouges and punches of antler, of which a considerable number, as well as prongs of

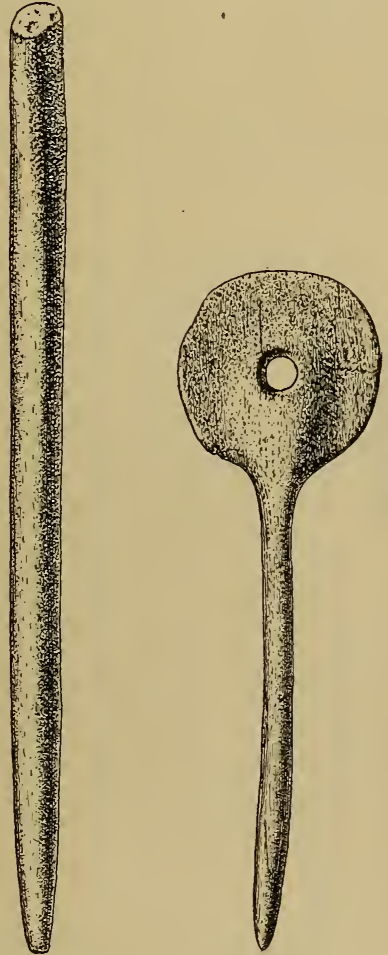

FIG. 69.-Bone punch.
FIG. 6I.-

Bone pin.

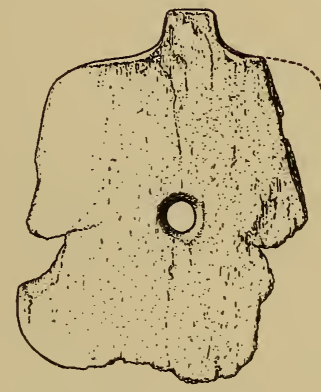

FIG. 62.-Ornament of tortoise-shell.

antlers that had no indication of artificial work, were encountered. The end of the largest prong is beveled to a chisel-like edge; the other examples were used.as awls or punches with little if any modification.

Tortoise-shell.-Two imperfect ornaments made from the carapace of tortoises were found (fig. 62). Both are perforated at 
the center, and had a pin-like projection at one end if not at both, but in each specimen it has been broken off.

Bear Tusks.-Mention has been made of the finding of numerous bones of the black bear in the refuse, indicating the abundance of that animal in former times and its use for food by the Nacoochee people. The presence likewise of hundreds of bear tusks suggests their use as implements for scratching and scoring wood, and probably also in pottery making. Indeed, as some of the tusks bear the marks of use both on the bony tissue and at the enameled end, there is little question that such an effectual tool should have been employed in various ways.

Wooden Ear-ornament.-The only preservable artifact of wood

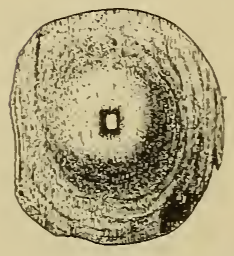

FIG. 63.-Wooden ear-ornament. found during the work is the small ear-button illustrated in fig. 63. This object, which was found with Burial 53 , had evidently formed the core of an ornament that had been thinly plated with copper which has entirely disappeared, leaving not even a stain on the wood to mark its former presence. The outer face is convex, the central part elevated, with an oblong aperture in the middle. The under side is chamfered at the edge and has a regular groove cut from opposite edges to the level of the chamfer. It is not certain that this core is complete.

\section{OBJECTS OF COPPER}

An account of the finding of the copper celt and sheet-copper ornament in the grave of Burial 46, and also of a similar celt and other copper objects in a grave unearthed by Captain Nichols near the western base of the mound, has already been given. It remains for us to mention two arm-bands of copper, each with a thin lining of bark, found on the skeleton of Burial 3 at a depth of 28 inches below the summit.

The first of these bands is $3 \frac{1}{4}$ inches wide at one end and $23 / 4$ inches at the other, and varies in. thickness from a sixteenth of an 



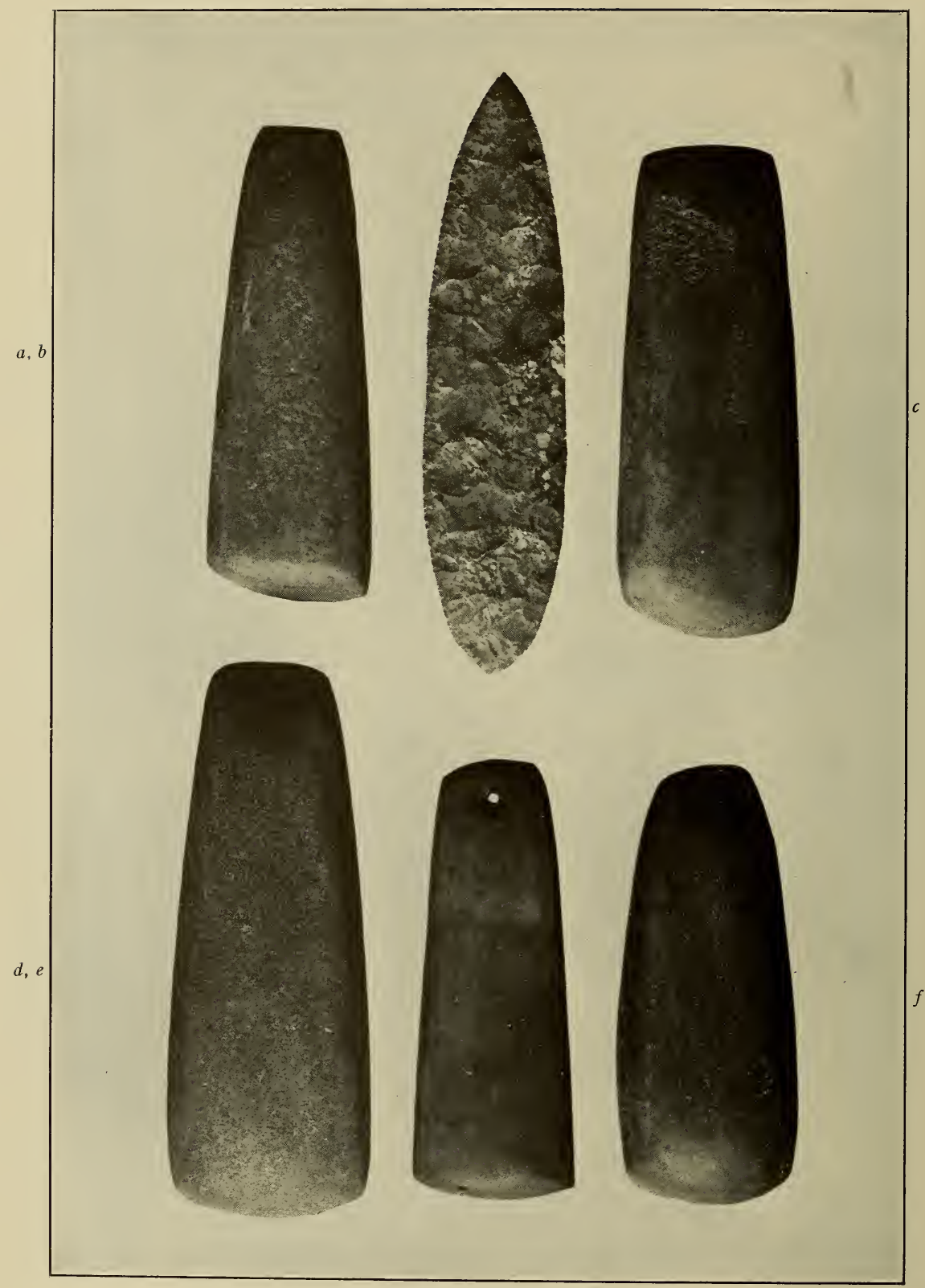


inch in its heaviest part to that of thick paper where corroded through, for it was broken into pieces when found. The band does not taper gradually from one end to the other, the narrower end having been cut away at one corner to a depth of $1 / 1 / 8$ inches from the termination. In this end two holes, and in the other one hole, have been punched, the roughened edges of the holes on the under side not having been removed.

The other arm-band is $3 \frac{1}{8}$ inches wide at each end, but is slightly wider at the middle and is of the same general thickness. Three equidistant holes have been punched in one end and two holes in the other, but in the latter a corresponding third hole was commenced and the attempt abandoned.

Particles of bark still adhere to the under side of the arm-bands, the remains of a thin padding or lining for the protection of the skin of the wearer. There is no reason to suppose that these armbands are of commercial copper, any more than that the copper celts are of foreign origin.

\section{Miscellaneous Materials}

Scattered here and there in the mound or in the graves were fragments of mica, hematite, quartzite and other stones, galena, and such like mineral substances, largely the rejecta of manufacture or materials used for paint. Some of the hematite and galena show surfaces smoothed by rubbing for the purpose of reducing the raw material to paint, and deposits of hematite and ocher in pasty masses but which had once been powder, no doubt, were found in some of the graves, as likewise were a few quartz crystals, so precious to Indian medicine-men generally.

The plaited matting and fragments of woven fabric found with Burial 46 have already been described and illustrated (pl. vir, XvI, and fig. 2).

With Burial 39, as before mentioned, were found seven small drilled pearl beads that evidently had been worn at the neck.

\section{ObJECTS OF Foreign ORIGIN}

Beads.-No objects derived from the white man were found in the mound at a depth of more than four feet. Articles of foreign 
provenience consist largely of glass beads, mostly spherical or barrel-shaped, blue or greenish blue, a number of them iridescent, a few striated with white. One of the blue beads is cylindrical, a little more than half an inch long, rounded at the ends, and much worn or weathered; another, also cylindrical, is half as long, with straight ends. There are also a couple of small plain white beads; two barrel-shaped ones, also white, each with three lines in red and blue, found with which, in Grave 4, were two smaller ones of the same shape but without the colored stripes; one purplish black in color with a netting of white wavy lines around the body; and one of amber-colored glass. The smallest of the blue-glass beads is less than an eighth of an inch in diameter, while the largest, somewhat barrel-shaped, is more than three-eighths of an inch long.

While most of these trade beads were found with comparatively recent burials, a few were recovered from the mound refuse. In two instances (Burials 3 and 4 ) trade beads in numbers were found with skeletons in association with native shell beads that had formed a breast ornament and a necklace respectively. It will be remembered that Captain Nichols plowed up in the adjacent field forty-five Venetian beads, "varying in shape and color, some of them being red, others blue, others white (of which variety some have a blue wreath, inlaid, encircling them), others green, with crimson and yellow horizontal stripes upon them, and others black." 1

Glass and Crockery.-Two fragments of bottle glass, one thin and green, the other thick and blue, were found not far beneath the surface, as likewise were some small pieces of crockery glazed on both surfaces.

Copper Objects. -With Burial 4 were a pair of well-made, circular, convex, copper buttons, $\mathrm{I} 1 / 8$ inch in diameter, with shanks, and with a small boss in the middle of the face. A fragment of tanned skin was attached to each button at the back, as if to form washers, or they may be parts of a skin garment to which the buttons were fastened, as they were found under the scapulæ and pelvis of the skeleton. In one of the shanks are remains of a

${ }^{1}$ Jones, op. cit., p. 235. 


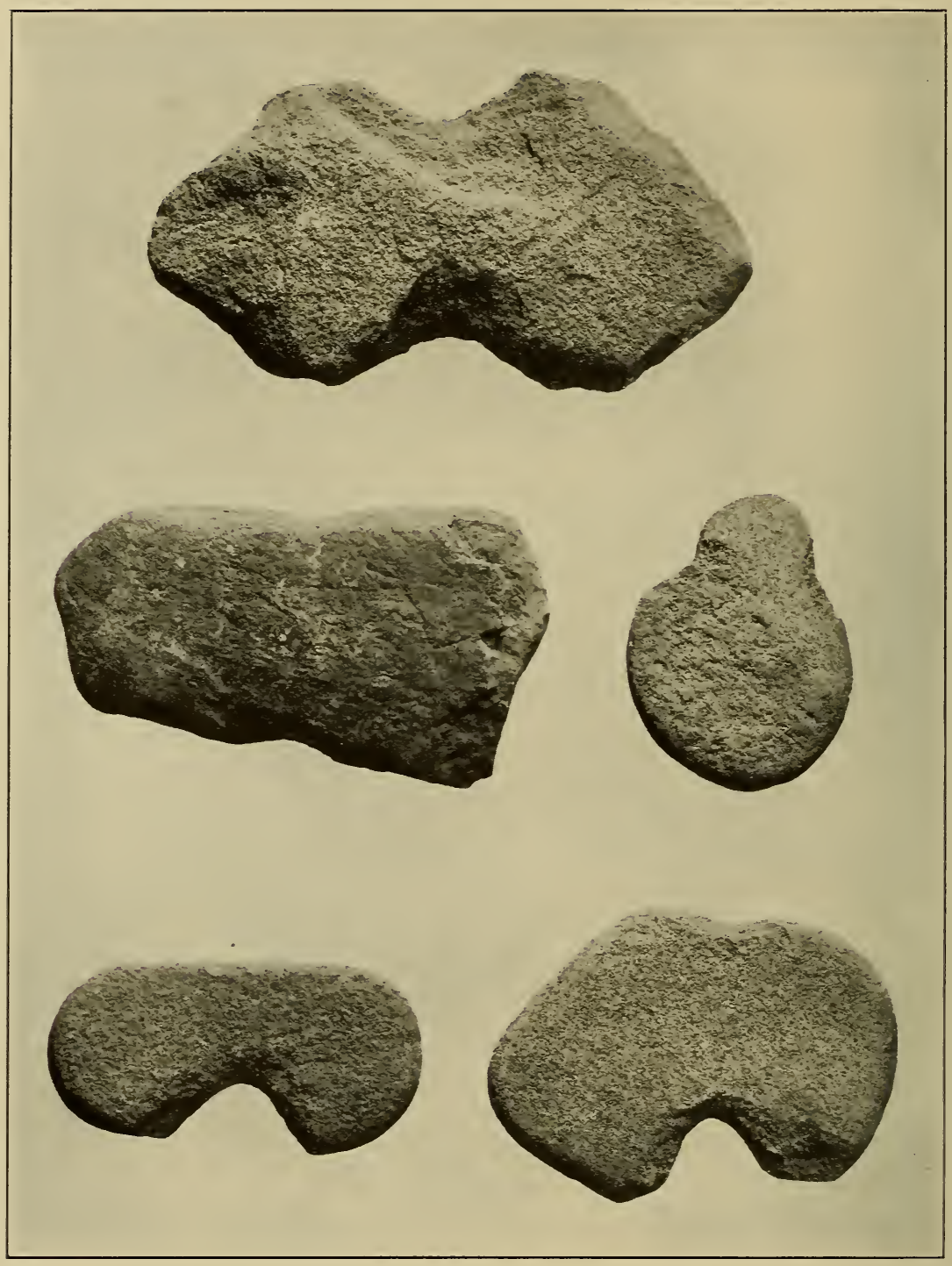

NOTCHED STONES 
fiber cord by which this button was attached, while with the other is a knot of dried skin, probably deerskin, evidently the remnant of a thong used in securing it.

A piece of sheet-copper, $23 / 4 \times 5 / 8$ inches, is ground sharp at one end apparently for use as a chisel.

Another intrusive object of copper and one of iron, found near the surface, are of no special significance, as they give no indication of aboriginal modification.

Lead Objects.-Most important among the objects of lead are thirteen buttons, more or less disintegrated, three of which were in front of the arms, three near the feet, and others under a stone pipe at the base of the pelvis of Burial 4-the skeleton with which the copper buttons were found. The lead buttons, while now of irregular circumference, measure one inch to an inch and an eighth in diameter, and each bears on the under or concave side a central boss or stem which does not seem to have been a looped shank. Possibly this stem at one time was sufficiently long to pass through the garment and the button secured by bending.

Three crudely molded bullets of lead and also half of a bulletmold of the same material were found in the upper refuse.

Mention has already been made of the finding of small fragments of clay trade pipes near the surface.

No more interesting intrusive object was found than the eightreal Spanish coin, dated $\mathbf{I} 808$, which was taken from slightly under the surface at the northeastern base of the mound. A smooth round hole punched near the top indicates that the coin had been used as a pendant. It was not associated with a burial, hence may be regarded as having been lost during the occupancy of the site, and therefore in a measure as establishing a limit. of time for its abandonment.

\section{SUMMARY}

The settlement of Nacoochee (Nagu'tsí'), with its artificial mound on which was the town-house, was inhabited by the Cherokee Indians from prehistoric times until about the year 1819, and is identified with the Guaxule of the chroniclers of the De Soto expedition in I540. As prescribed by Cherokee custom, the village 
was situated near a stream-the Chattahoochee river. Built of soil from the surrounding field, the mound at the time its excavation was commenced rose to an elevation of $I 7$ feet, 3 inches; its summit, which had been dug away to a depth of two feet years ago, was 67 feet 4 inches in minimum and 82 feet 9 inches in maximum diameter, with a circumference of $23 \mathrm{I}$ feet, while the basal circumference was about 4 Io feet. The mound was primarily domiciliary, but numerous interments were made therein.

Desultory excavations were made near the western base of the mound in 1870 by Captain Nichols, the owner of the property at that time, resulting in the finding of three stone graves, with numerous accompanying artifacts, including a copper celt and other copper objects, as well as specimens of matting, shell, and steatite and other stone, including the only grooved stone axe known from Nacoochee. In the nearby field other artifacts were plowed up, including a remarkable earthenware effigy pipe, which, with most of the other specimens found by Nichols, are now in the Museum of the American Indian, Heye Foundation.

Various stone-box graves were found in the mound by the expedition of I9I5, all in its lower levels; but there were also stone deposits, as if placed to mark the presence of burials, throughout the tumulus. By far the greater number of the interments, however, had been placed in earthen graves, and only twenty-seven of a total of seventy-five burials uncovered were accompanied with artifacts of any particular importance. Most of the dead were buried with their heads directed eastwardly. The skeletons were in a very poor state of preservation, none of them in condition for measurement. The remains of children were especially scanty, owing doubtless to complete decay.

The existence of fire-pits in various parts of the mound, on what had been its surface at the time of occupancy, as well as the stratigraphy of the mound deposits exposed by the trenches, which reached to a depth of more than I9 feet below the surface, showed beyond question that the mound had been built by gradual accretion and occupied during this process, which doubtless covered a long period of time. The finding of objects of European proven- 
ience, especially glass beads, metal buttons, etc., in association with aboriginal artifacts deposited with the dead, all within four feet of the surface, indicates that the mound had been occupied and used for mortuary purposes after the coming of white people.

Although two feet of earth had been taken from the summit many years ago, this removal did not disturb an immense fire-pit, or series of fire-pits one above another, found immediately beneath the summit, near the center. The charcoal remains of poles and canes nearby suggest that this pit may have contained the sacred fire of the town-house, referred to in Cherokee tradition.

The pottery vessels were chiefly cooking-pots and water-jars, some very large, ornamented on the outer surface with stamped rectangular or curvilinear patterns, or incised over the neck and sometimes inside the rim. Ornamental rims, applied after the body was thus decorated, vary greatly in style, dentate and beaded borders predominating. The walls of the vessels are generally comparatively thin, and shell, sand, and mica were used for tempering the clay. The color of the earthenware is the natural hue of the clay, paint not being used as a decorative motive. A single intrusive effigy vessel, found in a stone-box grave near the bottom of the mound, is painted brown and white-the only example of painted ware found. Most of the earthenware was found in the form of sherds in the refuse on the former slopes of the mound, only one entire jar being in association with a burial. A few sherds of small vessels that had been covered with a red slip were found here and there, at no particular level, and some of the jars were of the natural reddish color of the burned clay. Some of the vessels had been provided with handles in the form of loops, knobs, or ridges. A few of the knob handles consist of effigy heads.

Pipes were abundant, although mostly broken, and are of both earthenware and stone, especially steatite. A pipe of catlinite was found with a burial not far beneath the summit. Some of the earthenware pipes bearing bird effigies as decorative motives represent the height of Nacoochee art. The finest of these, as well as the best example of a steatite pipe, was found in the early seventies and is now in the Museum of the American Indian, Heye Foundation. 
Most numerous among the stone objects are the discoids, of varying forms and sizes, and made of various kinds of stone. They range in type from the very rude, to excellent symmetrical specimens with straight or beveled sides and rounded corners, made chiefly of dioritic and granitic stone, quartz, and marble. A few fine lanceolate chipped blades of chert, a number of large, wellfinished celts of slate and a granitic rock, some of them still showing the marks of hafting, and a comparatively few objects of the everyday kind, complete the product of the more noteworthy stone implements from Nacoochee, which cannot be regarded as in any way rich in material of this kind. With one burial forty-five arrowpoints were found, some of them exhibiting good workmanship. Stone ornaments were almost entirely absent.

Shell no doubt had been used rather extensively at Nacoochee for ornaments, but the condition in which shell objects were found was such that in most cases they were far beyond preservation.

- Hair- and ear-ornaments were the most common. Drinking-cups made of conchs from which the columellæ had been removed, were probably in frequent use, as fragments were found from top to bottom of the mound. Musselshells were used as scrapers (probably in finishing pottery), and snail-shells were sometimes employed in ornamenting the rims of vessels. Beads, made chiefly from the conch, and with considerable range in size, were found with various skeletons, sometimes in combination with glass beads. There are also beads made from olivella and other small shells.

Objects of bone and wood are almost insignificant, the only exception being a few bone ornaments (probably hair-pins) and implements, and the wooden core of an ear-ornament that had probably been covered with sheet-copper and thereby preserved.

Most important among the copper objects, and the most interesting specimen in many respects found in the mound, is a celt, recovered from a grave near the bottom, associated with a small piece of fabric and a fragment of matting diagonally plaited. Part of the wooden handle of the celt is still in place, showing the method of hafting. In one of the uppermost burials were a pair of barklined arm-bands of sheet-copper, without ornamentation. 
Nacoochee may be regarded as a typical Cherokee earthwork. While not rich in artifacts, the products of material culture are such as might have been expected to be revealed by the excavation of a Cherokee site occupied from prehistoric times through a considerable part of the historic period. The culture of its inhabitants had not been greatly modified by contact with civilization, for only the upper part of the mound revealed objects of European provenience. It is not likely that more than a few feet of the height of the mound were added during later historic times. Judging from Spanish descriptions of the sixteenth century the form of the mound became greatly changed after the advent of Europeans. 



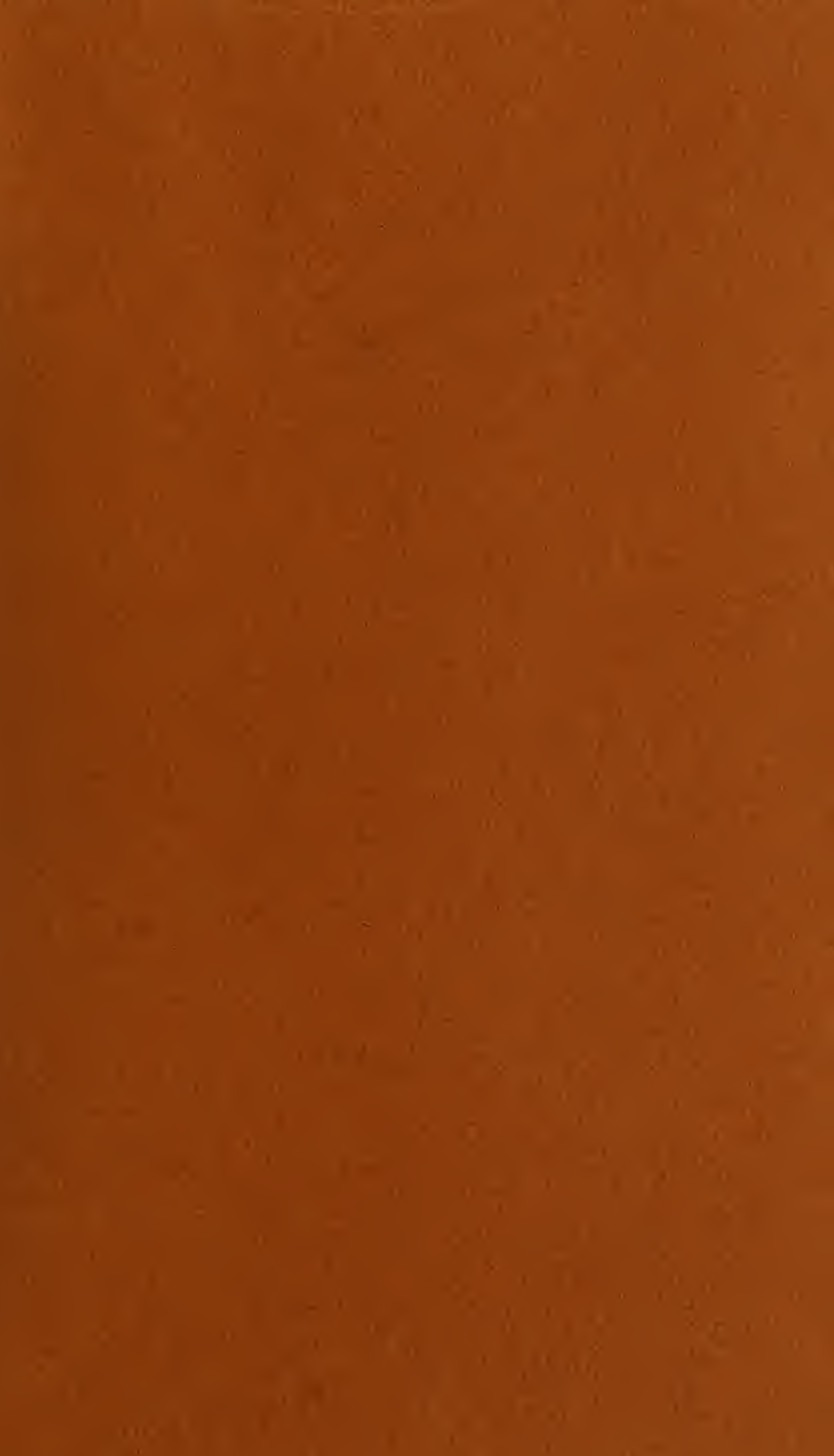


SMITHSONIAN INSTITUTION LIBRARIES

||||||||||||||||||||||||||||||||||||||||||||||||||||||||||||||||||

39088016090714

39088016090714 